Aline Moreira da Costa

\title{
Direitos Humanos e Previdência Social Brasileira à luz do princípio da proibição do retrocesso social
}

Dissertação de Mestrado

Orientador: Professor Doutor Guilherme Guimarães Feliciano

Faculdade de Direito da Universidade de São Paulo

São Paulo 
Aline Moreira da Costa

\title{
Direitos Humanos e Previdência Social Brasileira à luz do princípio da proibição do retrocesso social
}

\begin{abstract}
Dissertação apresentada ao Departamento de Direito do Trabalho e da Seguridade Social da Faculdade de Direito da Universidade de São Paulo, como exigência parcial para a obtenção do título de Mestre em Direito do Trabalho, sob a orientação do Professor Doutor Guilherme Guimarães Feliciano.
\end{abstract}

Faculdade de Direito da Universidade de São Paulo

São Paulo 


\section{FOLHA DE APROVAÇÃO}

Nome: COSTA, Aline Moreira da.

Título: Direitos Humanos e Previdência Social Brasileira à luz do princípio da proibição do retrocesso social.

Dissertação apresentada ao Departamento de Direito do Trabalho e da Seguridade Social da Faculdade de Direito da Universidade de São Paulo, como exigência parcial para a obtenção do título de Mestre em Direito do Trabalho, sob a orientação do Professor Doutor Guilherme Guimarães Feliciano. 


\section{DEDICATÓRIA}

Aos meus pais, Amaury e Vera, pelo exemplo de vida, pelo amor incondicional e pela confiança sempre depositada.

Aos meus irmãos de sangue Amanda e André, e de coração, Ricardo, pelo apoio, amizade e companheirismo em todas as horas.

Essa conquista é por vocês e para vocês. 


\section{AGRADECIMENTOS}

Nenhum estudo ou trabalho é feito em total isolamento. Todas as ideias desenvolvidas são fruto de parceria intelectual e de constantes discussões acadêmicas e práticas. Por essa razão, agradecimentos não apenas se fazem necessários, como também importantes para o reconhecimento daqueles que, de qualquer modo, contribuíram para que esta dissertação pudesse ser finalizada.

Agradeço primeiramente a Deus pela minha vida e saúde, sem a qual nada disso seria possível.

Agradeço imensamente ao professor Guilherme Guimarães Feliciano, pela orientação constante e pelo interesse partilhado pela matéria. Sem nossas conversas e seus valiosos conhecimentos, certamente esse trabalho não poderia ser construído.

Agradeço aos demais professores do Departamento de Direito do Trabalho e da Seguridade Social pelos ensinamentos transmitidos durante todo o curso de Mestrado, em especial aos Professores Marcus Orione Gonçalves Correia e Antonio Rodrigues de Freitas Junior, pelas importantes observações e aconselhamentos feitos a esse trabalho.

Agradeço aos grandes amigos das Arcadas Leandro Krebs, Gisele Martins, Cibele Linero e Victor Hugo de Almeida pela presença em todas as horas, pelas discussões acadêmicas, pelo apoio irrestrito, enfim, pela grande amizade que nos uniu durante essa conquista.

Agradeço, ainda, ao Dr. Eduardo Brock e a minha equipe da área trabalhista do DLBCA, pela ajuda e companheirismo nos momentos em que minha presença física e intelectual teve que ser sacrificada em prol de um objetivo acadêmico.

Por fim, agradeço a querida tia Célia, pelo oferecimento e disposição na revisão deste trabalho. Meu muito obrigada por tudo. 


\section{RESUMO}

A questão dos direitos humanos sempre teve como principal embasamento a noção de pessoa humana e sua dignidade. Corolário lógico dessa acepção é a formalização de tais direitos como previsões obrigatórias a todas as Constituições, de forma a garantir a limitação do poder do Estado e o pleno desenvolvimento da personalidade humana. Daí a noção de direitos fundamentais. O objetivo do presente estudo é analisar a questão do direito fundamental à Previdência Social no Brasil sob o prisma de sua importância como direito humano, e consequentemente, direito fundamental, e à luz do princípio da proibição do retrocesso social. Suporta-se na necessidade de observância dos princípios humanistas para uma efetiva e eficiente proteção dos direitos sociais no Brasil, sem os quais se deflagra retrocesso social. Tem sua relevância baseada em uma temática constantemente atualizada, consequência das várias mudanças enfrentadas pelo sistema de proteção social no Brasil, em especial o previdenciário, atualmente conduzidas muitas vezes sem qualquer preocupação do princípio basilar da dignidade da pessoa humana. Este trabalho é iniciado com a verificação da definição de direitos humanos e as questões a eles correlatas, tais como sua convolação em direitos fundamentais e a possibilidade de restrição ou limitação dos mesmos. Em seguida, é abordada a temática da proteção dos direitos humanos a partir da concepção de retrocesso social e o momento de sua efetivação, a partir da identificação do aspecto nuclear do direito a ser protegido. Na sequência, o direito fundamental à previdência social é avaliado desde sua percepção até sua fundamentação, em cada uma de suas nuances, sob os preceitos da proibição do retrocesso social. Por fim, à luz de tudo o quanto foi apurado, passa-se a uma análise concreta das hipóteses em que houve ameaça ou efetivação de retrocesso social na previdência social brasileira, bem como a possibilidade de sua permissão em determinadas situações, sem que isso se configure prejuízo à justiça social e à dignidade humana.

Palavras-chave: Direitos Humanos. Núcleo essencial. Previdência Social. Retrocesso Social. Reversibilidade. Dignidade humana. 


\begin{abstract}
The issue of human rights has always had as its main foundation the notion of the human person and his dignity. A logical corollary of this interpretation is the formalization of such rights as mandatory provisions in all Constitutions, as a way to insure the limitation of the power of the State and the full development of the human personality. Thence the notion of fundamental rights. The objective of the present study is to analyze the issue of fundamental rights to Social Security in Brazil under the angle of its relevance as a human right, and consequently, a fundamental right, and in the light of the principle of prohibition of a social regression. This is supported by the need to observe humanist principles for an effective and efficient protection of social rights in Brazil, which, if not present, a social regression is triggered. It has its relevance based on a theme that is being constantly updated, which is a consequence of several changes confronted by the system for social protection in Brazil, especially the social security segment, handled sometimes without any concern for the cardinal principle of dignity of the human person nowadays. This work begins with the verification of the definition of human rights and the issues correlated to it, such as its conversion to fundamental rights and the possibility for their restriction or limitation. Afterwards, it is addressed the thematic for the protection of human rights based on the conception of social regression and the moment it becomes effective, based on the identification of the core aspect of the right to be protected. In the sequence, the fundamental right to social security is evaluated from its perception to its institution, in each one of its nuances, under the precepts of the prohibition of social regression. Finally, in the light of everything that has been assessed, begins a concrete analysis of the hypotheses where there was a threat to or a materialization of social regression at the Brazilian social security, as well as the possibility to allow it in particular situations, without any damage to social justice and to human dignity.
\end{abstract}

Key words: Human rights. Essential core. Social Security. Social Regression. Reversibility. Human dignity. 


\section{SUMÁRIO}

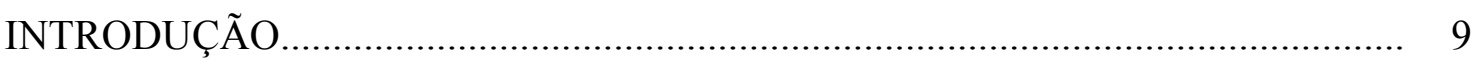

1 DOS DIREITOS HUMANOS................................................................... 13

1.1 Noções introdutórias: aspectos históricos e sociológicos.................................. 13

1.2 Os direitos humanos e a dignidade da pessoa humana........................................ 25

1.3 Da concepção contemporânea dos direitos humanos (individuais e sociais)

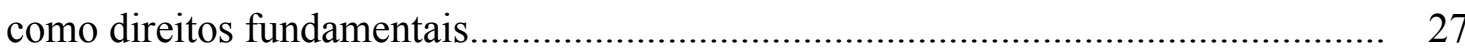

1.4 Das normas de direitos fundamentais......................................................... 31

1.5 A questão da limitação (e da restrição) aos direitos humanos fundamentais....... 35

1.5.1 Da proporcionalidade e da razoabilidade............................................... 38

1.5.2 Do conteúdo (núcleo) essencial dos direitos fundamentais........................ 43

1.6 A influência da noção de direitos humanos no ordenamento jurídico brasileiro:

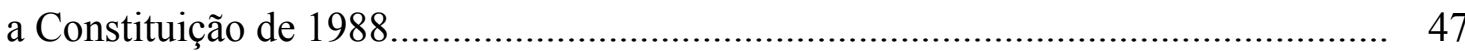

2 DA PROTEÇÃO DOS DIREITOS HUMANOS: O PRINCÍPIO DA PROIBIÇÃO DO RETROCESSO SOCIAL ............................................................................ 51

2.1 A Proteção dos Direitos Humanos................................................................. 51

2.1.1 Identificação do aspecto nuclear do direito a ser protegido........................ 52

2.2 Evolução histórica e definição do princípio do retrocesso social......................... 59

2.2.1 Posicionamentos contrários versus fundamentos..................................... 68

2.2.2 Do alcance do conceito de retrocesso social............................................ 72

2.3 A Constituição dirigente: instrumento de realização da justiça social................. 76

$2.4 \mathrm{O}$ retrocesso social como ofensa à dignidade da pessoa humana....................... 86

2.4.1 A proibição como mecanismo de defesa de direitos fundamentais............. 87

2.4.2 A proibição como solução para o dilema da natureza não pétrea das normas definidoras de direito sociais............................................................ 91

2.5 Dos efeitos e consequências da proibição do retrocesso social............................ 94

2.6 Antecedentes comparativos: jurisprudência..................................................... 100

2.7 Da aplicação do retrocesso social diante da globalização.................................. 104

3 DIREITOS HUMANOS SOCIAIS: DO DIREITO À PREVIDÊNCIA SOCIAL.... 110

3.1 Breve notícia histórica........................................................................... 110

3.2 Do direito fundamental à Previdência Social................................................... 115

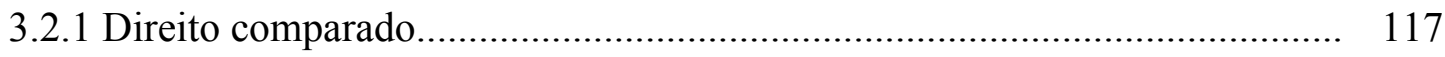


3.2.2 A interpretação do Direito Previdenciário.

3.3 Definição, estrutura e fundamento do direito à Previdência Social..................... 125

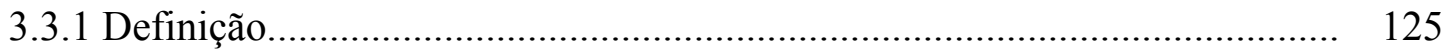

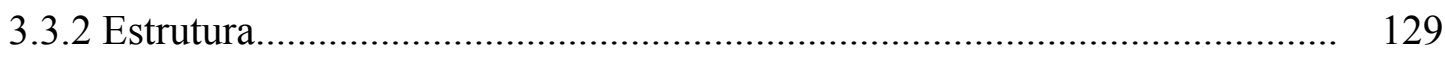

3.3.2.1 Do Custeio.................................................................................... 132

3.3.2.2 Das Prestações............................................................................. 136

3.3.3 Fundamento formal e material................................................................. 141

3.3.3.1 Da questão da solidariedade........................................................ 143

3.3.3.2 Da garantia institucional e dever do Estado....................................... 147

4 DA APLICAÇÃO CONCRETA DO PRINCÍPIO DA PROIBIÇÃO DO RETROCESSO SOCIAL NA PREVIDÊNCIA SOCIAL BRASILEIRA.................. 152

4.1 A adequação de hipóteses de reversibilidade do nível de proteção de acordo com o princípio da proibição do retrocesso social..................................................... 152

4.2 Da modulação temporal de efeitos no controle de constitucionalidade pela proibição do retrocesso social............................................................................... 159

4.3 Da análise dos casos práticos.................................................................... 165

4.3.1 Fator Previdenciário na aposentadoria por tempo de contribuição.............. 165

4.3.2 A qualificação do garimpeiro no Regime Geral de Previdência Social

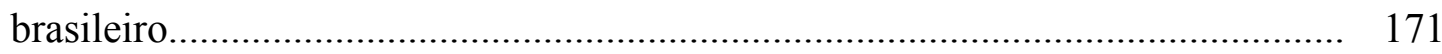

4.3.3 Proteção constitucional ao acidente de trabalho.......................................... 176

4.3.4 Auxílio Reclusão - concessão do benefício................................................ 184

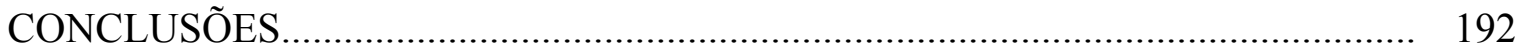

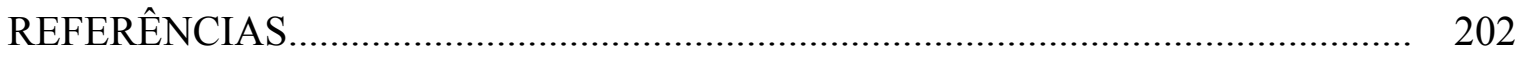




\section{INTRODUÇÃO}

O surgimento da Previdência Social no Brasil foi embasado nos ideais trazidos ao longo da evolução dos direitos humanos na história mundial. E, como tal, a proteção previdenciária deve ser analisada e, eventualmente, modificada à luz dos princípios atinentes àquela específica matéria.

Assim sendo, é correto afirmar que os princípios de Direitos Humanos são pressupostos de existência dos direitos sociais no Brasil e no mundo, e um importante pilar de sustentação do sistema previdenciário brasileiro.

Do mesmo modo, o objetivo traçado pela Previdência Social brasileira é o alcance da plenitude da dignidade da pessoa humana, estabelecido como fundamento da República Federativa do Brasil, consubstanciado pela justiça social.

Diante dessas questões, o presente trabalho tem como objetivo analisar a questão do direito fundamental à Previdência Social no Brasil sob o prisma de sua importância como direito humano e à luz do princípio da proibição do retrocesso social. Fundamenta-se na necessidade de observância dos princípios humanistas para uma efetiva e eficiente proteção dos direitos sociais no Brasil, sem os quais deflagra-se retrocesso social.

Tem sua relevância baseada na temática atual, consequência das constantes mudanças enfrentadas pelo sistema de proteção social no Brasil, em especial o previdenciário, atualmente conduzidas, muitas vezes, ao arrepio do princípio basilar da dignidade da pessoa humana.

O primeiro capítulo destina-se à avaliação das questões de direitos humanos, sua evolução histórica e sociológica e sua estreita ligação com a dignidade da pessoa humana. A questão dos direitos fundamentais também é abordada, assim como a questão da possibilidade de limitação ou restrição de tais direitos.

A questão da limitação ou restrição dos direitos fundamentais, conforme a teoria que se adote, conta com a verificação dos postulados da proporcionalidade e da razoabilidade, cuja definição também é apurada no presente trabalho, para se chegar ao estudo do conteúdo 
essencial do direito fundamental, elemento de grande importância para a pesquisa que ora se propõe.

O capítulo primeiro ainda traz em sua estrutura a análise da formação humanista da Constituição Federal do Brasil de 1988 como forma de avaliar a influência e o impacto de toda a concepção de direitos humanos e dignidade humana, direitos fundamentais e núcleo essencial no ordenamento jurídico brasileiro.

O segundo capítulo é destinado ao estudo da proteção dos direitos humanos a partir da concepção de retrocesso social e da verificação de um princípio que proíbe sua efetivação. Nessa medida, aspectos de evolução histórica e definição dessa temática apresentam grande relevância em uma tentativa de apurar os objetivos da proibição do retrocesso.

Durante esta parte do trabalho, busca-se identificar o aspecto nuclear do direito a ser protegido, de forma a se vislumbrar em que momento o retrocesso social pode se apresentar. O surgimento do conceito de proibição de retrocesso social, idealizado pelo Professor José Joaquim Gomes Canotilho, dentro de uma chamada Constituição dirigente, criada para realizar a justiça social, também se torna objeto imprescindível de análise.

A partir do desenvolvimento do estudo do princípio da proibição do retrocesso social, passa-se a avaliar os efeitos e consequências dessa medida, bem como a forma com a qual a jurisprudência se coloca diante de questões retrocessivas. Ainda, busca-se aprofundar o exame da aplicação deste princípio, seja como mecanismo de defesa dos direitos fundamentais, seja como solução para a questão da natureza não pétrea das normas de direitos fundamentais.

Não menos importante, o segundo capítulo ainda traz uma avaliação da possibilidade de aplicação do princípio da proibição do retrocesso social em um mundo globalizado.

Após o estudo da identificação, formação e aplicação do princípio da proibição do retrocesso social, objetiva o terceiro capítulo analisar o próprio direito fundamental à previdência social, verificando seu surgimento no ordenamento jurídico estrangeiro e brasileiro e traçando paralelos à sua concepção como direito fundamental para fins de demonstrar a aplicabilidade do princípio abordado neste trabalho às suas diretrizes. 
Faz-se necessária uma avaliação do direito comparado e da forma de interpretação do próprio direito previdenciário a partir de sua fundamentalidade, a fim de apurar seu núcleo essencial e os parâmetros da aplicação do princípio do não retrocesso social às suas específicas hipóteses.

Por intermédio da premissa da aplicabilidade do princípio objeto desse estudo no ordenamento jurídico brasileiro, far-se-á a verificação da estrutura do direito à Previdência Social brasileira, desde sua definição até sua fundamentação, analisando a proibição do retrocesso em cada uma de suas nuances: financiamento do sistema e concessão das prestações, limitando-se à apuração das alterações sistemáticas consideradas emblemáticas a partir da Constituição de 1988.

Na parte de financiamento do sistema de previdência social é imprescindível salientar as medidas tomadas para garantir a manutenção e a eficiência do sistema, sem que isso afete a proteção social constitucionalmente prevista. Em suma, é preciso apurar se as implicações financeiras de um sistema de custeio, seja na arrecadação ou na distribuição de valores, não inviabilizarão ou restringirão a garantia social constitucional da concessão de benefícios previdenciários.

No que tange às prestações previdenciárias, a análise do princípio da proibição do retrocesso social ganha novos contornos, a partir de um entendimento de que a concessão de tais benefícios ou serviços é um dos instrumentos de garantia da dignidade da pessoa humana. Assim, por se tratar de uma proteção social e alavancada por objetivar ao alcance de uma justiça social, a concessão de prestações previdenciárias demanda uma análise sintomática da questão do retrocesso social. Principalmente, porque, nessas específicas hipóteses, deve ser considerada uma necessária posição ativa do Estado na consecução dessas garantias.

Outro aspecto merecedor de destaque neste capítulo é a questão do fundamento formal e material do direito à Previdência Social. A partir da verificação do princípio da solidariedade (sociedade livre, justa e solidária), denota-se que a previdência social é realizada com base no próprio objetivo da República Federativa do Brasil. E como tal, deve ter sua estrutura garantida pelo Estado, na medida em que é parte da função estatal a viabilização dos meios para atingimento dos objetivos previstos na Constituição. 
Portanto, independentemente do ângulo que se analise a questão, o próprio embasamento do direito fundamental social à Previdência Social justifica o estudo dessa temática à luz do princípio da proibição do retrocesso social.

A partir de tudo o que foi demonstrado nos capítulos anteriores do estudo ora realizado, o capítulo quarto e último passa a uma análise concreta das hipóteses em que houve ameaça ou efetivação de retrocesso social no ordenamento jurídico brasileiro, avaliando as situações em que a legislação brasileira deixou de observar a aplicação do princípio da proibição do retrocesso social e quais as consequências dessa alteração para a proteção social e para a dignidade da pessoa humana.

Esse capítulo também se presta a perquirir, a partir de circunstâncias concretas, se, em determinadas situações, é possível a flexibilização da observância do princípio do não retrocesso social, isto é, se é possível admitir, mesmo à luz de toda a fundamentação supra, que o retrocesso social possa ser permitido em certas situações concretas, sem que isso se reflita em prejuízo à dignidade humana.

Ainda, se possível a flexibilização do princípio da proibição do retrocesso social, é importante apurar se, por outro lado, os efeitos dessa proibição podem ser modulados pelo legislador, a partir de emendas constitucionais e/ou leis infraconstitucionais, para fins de, no caso da Previdência Social em específico, viabilizar o sistema sob o aspecto econômicofinanceiro.

Em suma, torna-se relevante avaliar os efeitos da vedação ao retrocesso social, não só no sentido de proibir restrições, mas também no sentido de exigir atuações ativas do Estado, a fim de garantir um sistema previdenciário voltado à proteção da dignidade humana e à justiça social. 


\section{DOS DIREITOS HUMANOS}

\subsection{Noções introdutórias: aspectos históricos e sociológicos}

Um dos maiores desafios do estudo acerca dos direitos humanos é precisar o momento no qual o homem se percebeu detentor de direitos. E mais além: qual o fundamento de tais direitos.

A análise da história dos direitos humanos pode ser realizada sob vários aspectos. Pode-se apoiar em uma história religiosa, iniciada com base em um controle total da vida humana pela religião e sucedida pela afirmação da fé monoteísta, que modificou, intensamente, o sistema de valores até então existente. ${ }^{1}$

É possível, ainda, basear-se em uma história filosófica, iniciada na Antiguidade clássica, na qual o ponto de partida é a descoberta do homem como objeto de reflexão, despertando a consciência da unidade do gênero humano ${ }^{2}$, por meio de um conhecimento racional. Ou sustentar-se por uma história política, a partir dos ideais introduzidos pela Magna Charta Libertatum, acatada pelo rei inglês João Sem Terra, em $1215^{3}$.

Diante do que ora se pretende perquirir, optar-se-á pela análise dos direitos humanos a partir de uma história social, ou seja, a partir de um ponto de referência emocional interior ${ }^{4}$ que impulsionou, retardou ou até modificou o desenvolvimento e a efetividade dos direitos humanos na sociedade ${ }^{5}$.

A determinação dos direitos humanos repousa no entendimento de que sua definição (e até sua própria existência) é dependente da razão e da emoção. Nesse sentido, "baseiam-se

\footnotetext{
1 "A justificativa religiosa da preeminência do ser humano no mundo surgiu com a afirmação da fé monoteísta.

${ }^{2}$ COMPARATO, Fábio Konder. Ética: direito, moral e religião no mundo moderno. 2. ed. rev. São Paulo: Companhia das Letras, 2006. p. 87.

3 Magna Charta Libertatum seu Concordiaminter regem Johannesatbarones pro concessione libertatumecclesiae et angliae (Grande Carta das Liberdades, ou Concórdia entre o rei João e os Barões para a outorga das liberdades da Igreja e do rei inglês - Trad. livre). Documento assinado pelo rei João da Inglaterra renunciando a certos direitos e reconhecendo sua sujeição à lei. Consubstanciou-se no primeiro passo de um longo processo histórico que culminou no surgimento do constitucionalismo.

4 "Os direitos humanos não são apenas uma doutrina formulada em documentos: baseiam-se numa disposição em relação às outras pessoas, um conjunto de conviç̧ões sobre como são as pessoas e como elas distinguem o certo e o errado no mundo secular. (HUNT, Lynn. A Invenção dos Direitos Humanos: uma história. Trad. Rosaura Eichenberg. São Paulo: Companhia das Letras, 2009. p. 25).

${ }^{5}$ José Damião de Lima TRINDADE. História Social dos Direitos Humanos. São Paulo: Peirópolis, 2002. p. 16.
} 
numa disposição em relação as outras pessoas, um conjunto de convicções sobre como são as pessoas e como elas distinguem o certo e o errado no mundo secular."6

A questão dos direitos humanos, ao longo de suas quatro gerações, sustenta-se, basicamente, em uma predisposição com relação ao outro, em uma visão internalizada de empatia, de reconhecimento como semelhante.

Analisando a questão sob essa perspectiva, imprescindível iniciar o estudo a partir de uma breve trajetória da concepção do ser humano como "pessoa humana".

Não havia, em um primeiro momento, a consciência de autonomia e individualidade. O conceito de "homem" era relacionado aos integrantes de um grupo, sendo os estranhos a este grupo considerados indivíduos de espécie animal diversa, assumindo outra denominação. ${ }^{7}$

A convicção de que os seres humanos são iguais simplesmente pela sua humanidade, adveio do período axial da História. Foi durante esse período que, em razão dos ensinamentos de doutrinadores como Zaratustra, Buda, Lao-Tsé, Confúcio, Pitágoras e Isaías, as crenças mitológicas, coletivas e indiretas, são abandonadas e passa-se a ter um culto mais pessoal e mais ético, mais consciente da individualidade. ${ }^{8}$

Por outro lado, o surgimento de regras gerais e uniformes, escritas e não escritas, de organização do grupo de pessoas, reforça o entendimento de que os homens possuem uma igualdade essencial. A função social dos sujeitos dentro de uma comunidade, aliada à noção de demarcação entre os corpos individuais (respeito das funções corporais e decoro corporal ${ }^{9}$ ), contribuíram para uma nova sensibilidade: o reconhecimento da autonomia dos indivíduos ${ }^{10}$.

\footnotetext{
${ }^{6}$ HUNT, op. cit., p. 25.

${ }^{7}$ COMPARATO, op. cit., p. 24.

${ }^{8}$ COMPARATO, Fábio Konder. Ética: direito, moral e religião no mundo moderno. 2. ed. rev. São Paulo: Companhia das Letras, 2006. p. 37/38.

${ }^{9}$ HUNT, op. cit., p. 28.

10 "Em outros autores gregos, a igualdade essencial do homem foi expressa mediante a oposição entre a individualidade própria de cada homem e as funções ou atividades por ele exercidas na vida social. essa função social designava-se, figurativamente, pelo termo prósopon, que os romanos traduziram por persona, com o sentido próprio de rosto, ou, também, de máscara de teatro, individualizadora de cada personagem." (COMPARATO, Fábio Konder. Afirmação Histórica dos Direitos Humanos. 7. ed. rev. e atual. São Paulo: Saraiva, 2010. p. 28).
} 
Foram os estoicos ${ }^{11}$, porém, quem mais desenvolveram a questão da unidade substancial do homem, que não se resume à sua aparência corporal ou à sua função dentro da sociedade. Diante da unidade do ser humano e de sua consequente dignidade, todos são possuidores de direitos inatos e iguais, indistintamente.

Foi sobre essa concepção de pessoa, advinda do período medieval, que a elaboração do princípio da igualdade essencial de todo ser humano repousa. E nos dizeres de Comparato:

é essa igualdade de essência da pessoa que forma o núcleo do conceito universal de direitos humanos. A expressão não é pleonástica, pois que se trata de direitos comuns a toda a espécie humana, a todo homem enquanto homem, os quais, portanto, resultam da própria natureza, não sendo meras criações políticas. ${ }^{12}$

Apurada a conceituação da pessoa humana, impende-se verificar a evolução dos direitos inerentes ao homem, a partir de uma história social (e sociológica).

Muito embora a preocupação com a conceituação da pessoa humana remonte à Antiguidade, durante esse período histórico, o indivíduo era considerado apenas como objeto de poder, devendo submeter-se às determinações traçadas por aqueles que se beneficiavam da exploração, da opressão ou da intolerância.

Desse modo, muito embora se possa notar a individualização do ser humano, as obrigações a ele impostas têm maior relevância do que os eventuais direitos existentes. Até mesmo porque não havia qualquer previsão de proteção desses direitos quando ameaçados, restringidos ou subtraídos. Na realidade, eram apenas meras faculdades.

O modo de organização do regime feudal, fundado basicamente numa rígida estratificação social decorrente do princípio do privilégio de nascimento, promovia amarras

\footnotetext{
11 "Para os estóicos, a natureza (physis) se confunde com a razão (logos). A natureza e o princípio racional que, ao mesmo tempo, ordena dialeticamente as idéias, estabelece a estrutura do mundo sensível e dirige as ações humanas; ou seja, estabelece as leis do pensamento, do mundo físico e da vida ética". [Surgida no século III a.C.] "a visão estóica do mundo, como se vê, é essencialmente unitária. O homem não abre exceção à lei universal da natureza, nem se separa da divindade. Em si mesmo, ele é também um ser uno, não dividido em alma e corpo." COMPARATO, Fábio Konder. Ética: direito, moral e religião no mundo moderno. 2. ed. rev. São Paulo: Companhia das Letras, 2006. p. 109/110).

${ }^{12}$ COMPARATO, Fábio Konder. Afirmação Histórica dos Direitos Humanos. 7. ed. rev. e atual. São Paulo: Saraiva, 2010. p. 32.
} 
sobre a vida e sobre todas as atividades das pessoas. O domínio político, jurídico e ideológico sobre a população era realizado por nobres e pela alta hierarquia da Igreja, porquanto detentores da única fonte de sobrevivência e riqueza: a terra, cuja acessibilidade era restrita aos "bem-nascidos".

Com o passar do tempo, novas formas de sentimentos e compreensões foram surgindo no interior das mentes individuais. Por meio do desenvolvimento das linhas sociais (fomentado através da empatia ${ }^{13}$ criada pela interação social), iniciou-se um questionamento acerca da ausência de certos direitos, ou melhor, sobre a impossibilidade de tê-los observados e garantidos.

Tais sentimentos invariavelmente produziam revoltas dos servos camponeses contra os senhores feudais. Por vezes, obtinham algumas concessões, em outras, eram sumariamente massacrados. Todavia, tais revoltas não tinham o condão de modificar a estrutura vigente, posto que em pequena escala e sem grandes recursos.

Alguns acontecimentos sociais, no entanto, unificados à insatisfação crescente, impulsionaram a busca pela modificação do sistema.

O primeiro deles foi a Peste Negra, doença que vitimou mais de vinte milhões de pessoas em toda a Europa. O despovoamento causado pelas mortes, somado à percepção de que inexistia qualquer privilégio divino a diferenciar nobres, padres e plebeus, posto que indistintamente atingidos pela doença, fortaleceram movimentos contra a opressão. ${ }^{14}$

É importante esclarecer, no entanto, que tal acontecimento não teve o condão de deflagrar a modificação da estrutura social até então existente. Mesmo porque as revoltas havidas eram acontecimentos isolados e, apesar de terem promovido abalos sociais, não foram suficientes para determinar o declínio do feudalismo. Porém, não se pode negligenciar sua

\footnotetext{
13 “A capacidade de empatia é universal, porque está arraigada na biologia do cérebro: depende de uma capacidade de base biológica, a de compreender a subjetividade de outras pessoas e ser capaz de imaginar que suas experiências interiores são semelhantes às nossas." (HUNT, op. cit., p. 39).

${ }^{14}$ Insurreição da Jacquerie (1358), Revolta dos Ciompi (Florença, 1378), Revolta dos Camponeses na Inglaterra (1381). (TRINDADE, op. cit., p. 23-24).
} 
importância no "recrudecimento das lutas dos servos contra os senhores feudais - estas, sim, a longo prazo, decisivas." 15

Outro aspecto social merece grande destaque na busca pelos direitos humanos na Idade Média: o renascimento urbano. Porém, diferentemente do ocorrido no século XIV, as consequências dessa alteração social tiveram importância fundamental na deflagração e no reconhecimento dos direitos inerentes ao homem.

O surgimento de pequenas cidades ao longo das rotas comerciais, conhecidas como burgos, fez desenvolver uma nova classe de pessoas dentro da estrutura social feudal. Os burgueses, como foram nomeados, formavam um conjunto de pessoas que não estavam submetidas ao trabalho nos feudos, seja porque haviam comprado sua liberdade, seja porque haviam fugido de seus senhores ou até porque vinham de famílias que sempre se dedicaram a atividades mercantis. Somados a estes, ainda havia os advogados, funcionários administrativos e toda sorte de profissionais que não mais residiam nos feudos. ${ }^{16}$

Como a maioria dos burgueses estava envolvida com negócios mercantis, aos poucos começou a acumular algum capital, passando a obter um padrão de vida superior, constituindo uma elite economicamente independente e influente. Todavia, em razão da estratificação social que a estrutura feudal trazia, os burgueses, apesar de sua influência junto ao Estado monárquico, não tinham acesso à participação política. E essa limitação passou a criar empecilhos ao crescimento econômico (além de político, por óbvio) dessa classe ascendente.

A busca de uma maior ingerência no Estado, cumulado com um "clima intelectual de franco triunfo do racionalismo" 17 promove o nascimento de um movimento científico, cultural

\footnotetext{
${ }^{15}$ TRINDADE, op. cit., p. 24.

${ }^{16}$ Ibid., p. 25.

17 "Isso não é de se estranhar, se considerarmos o bem sucedido ataque que, no mínimo havia uns duzentos anos, vinha sendo feito de forma cada vez mais atrevida à visão do mundo com que a religião (o pensamento mágico em geral) legitimava o feudalismo. Copérnico causou sacrossanto estupor ao concluir que a Terra não era o centro do Universo, mas apenas um pequeno planeta, entre outros, que orbitava em torno do Sol. Para os dias de hoje, isso parece de uma obviedade trivial, mas no começo do século XVI representou uma colisão com mais de mil anos de crença geocêntrica, segundo a qual o homem, por ter sido criado à imagem e semelhança de Deus, ocupava o centro do mundo. Galileu Galilei, além de comprovar o heliocentrismo com seu telescópio, lançou as bases do método científico, fundado em observação sistemática e demonstração experimental, e não em dogmas. A circunavegação do globo por Fernão de Magalhães liquidou de vez o mito da Terra plana. Newton revolucionou a física e a matemática, para a busca da verdade. Até a Igreja foi abalada estruturalmente pelas fraturas protestantes, que defendiam a comunicação direta do fiel com Deus, desmascaravam a degeneração do alto clero e legitimavam o lucro como bom e moral. Com tantos antecedentes, o século XVIII tinha todos os
} 
e artístico, "impulsionado principalmente pela reforma protestante e pelo humanismo (que) exercerá influência decisiva entre a era medieval e a moderna."18 Esse movimento fícou conhecido como Renascimento $^{19}$, traduzido como uma nova visão de mundo estimulada pela burguesia em ascensão, no qual pregava-se o racionalismo em oposição à fé, ao antropocentrismo em oposição ao teocentrismo e o individualismo em oposição ao coletivismo cristão.

Diante dessa recém descoberta visão humanista, em 1789 foi deflagrada uma revolução, posteriormente denominada Revolução Francesa, na qual foi estabelecida e registrada uma revalorização do indivíduo, com a identificação de direitos inerentes ao homem, por meio da Declaração dos Direitos do Homem e do Cidadão.

Com essa Declaração, considerada como representante do fim do antigo regime absolutista, surge a concepção plena do homem como sujeito dotado de direitos, em especial direitos ligados à noção de liberdade. São considerados direitos naturais e imprescindíveis do homem: a liberdade, a propriedade, a segurança e a resistência à opressão. ${ }^{20}$. A Declaração dos Direitos do Homem e do Cidadão representou, portanto, a garantia dos direitos fundamentais do homem, com a ascensão da burguesia ao poder.

Surge, então, em uma afecção moderna, a primeira noção de direitos humanos, qual seja, os direitos inerentes ao homem relativos à liberdade. Para muitos, é considerada a primeira geração de direitos humanos, em razão de seu ineditismo.

Entretanto, vale relembrar que, antes da Declaração dos Direitos do Homem e do Cidadão firmada na França em 1789, na América já havia previsão de direitos inerentes ao

motivos para ver na razão a potência finalmente capaz de entender a natureza e a sociedade, explicar a própria religião, libertar o homem dos seus terrores seculares, desvendar todos os mistérios, reformar tudo. Os filósofos do Iluminismo fizeram uma audaciosa construção intelectual nesse norte, Locke, Voltaire, Montesquieu, Diderot, Condorcet, Rousseau - só para mencionar algumas das grandes mentes que, malgrado tantas diferenças e divergências entre si, desconstruíram metodicamente as estruturas da visão social de mundo do feudalismo." (TRINDADE, op. cit., p. 35-36)

${ }^{18}$ ROCHA, Daniel Machado da. O Direito Fundamental à Previdencia Social na perspectiva dos princípios constitucionais diretivos do sistema previdenciário. Porto Alegre: Livraria do Advogado Editora, 2004. p. 24.

19 Movimento de redescoberta e revalorização das referências culturais da Antiguidade Clássica, surgido na Itália, que direcionou mudanças em busca de um ideal humanista e naturalista.

${ }^{20}$ Artigo $2^{\mathrm{a}}$ da Declaração dos Direitos do Homem e do Cidadão, aprovada em 26 de agosto de 1789. 
homem $^{21}$, influenciados pelas obras do pensador universalista inglês John Locke, que ajudou a formar o pensamento político americano. Em 12 de junho de 1776 foi editada a Declaração de Direitos da Virgínia, que proclamava expressamente a igualdade indistinta entre os homens $^{22}$ e em 04 de julho de 1776 foi apresentada a Declaração de Independência dos Estados Unidos da América, na qual os ideais de liberdade, igualdade, propriedade e segurança eram importantes pilares do novo regime democrático de governo, no qual o primeiro e único objetivo era "cuidar da vida e da felicidade humanas, e não de sua destruição". 23

De qualquer sorte, a partir dessas declarações, os direitos naturais converteram-se em direitos constitucionais, permitindo ao homem reivindicá-los a qualquer tempo, inclusive sobrepondo-se às leis que deixarem de observá-los.

Com o direito à liberdade devidamente previsto e tutelado, o homem passou a buscar a consolidação de seu poder econômico, através da realização do trabalho. A burguesia, promovedora da revolução em prol de sua liberdade de negociar, ao ascender ao poder, trata de realizar a limitação da intervenção estatal no processo econômico ao mínimo possível, de modo que os cidadãos livres e iguais deveriam estabelecer suas próprias regras nas relações entabuladas entre si. ${ }^{24}$ Cria-se, portanto, a concepção de Estado Liberal, ou Estado de Intervenção Mínima, no qual as crises sociais são resolvidas pela própria sociedade civil sem qualquer intervenção estatal, ficando esta restrita à garantia da segurança externa. ${ }^{25}$

Através da busca pelo crescimento econômico e pela acumulação de capital, surge a Revolução Industrial, caracterizada pelo desenvolvimento da economia capitalista e pela

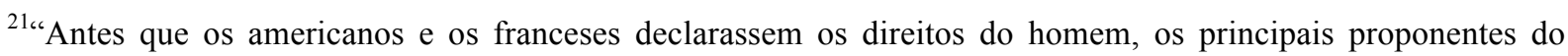
universalismo viviam às margens das grandes potências. Talvez essa própria marginalidade tenha capacitado um punhado de pensadores holandeses, alemães e suíços a tomar a iniciativa no argumento de que os direitos eram universais. Já em 1625, um jurista calvinista holandês, Hugo Grotius, propôs uma noção de direitos que se aplicava a toda a humanidade, não apenas a um país ou a uma tradição legal. Ele definia 'direitos naturais' como algo autocontrolado e concebível separadamente da vontade de Deus. Sugeria também que as pessoas podiam usar os seus direitos - sem a ajuda da religião - para estabelecer os fundamentos contratuais da vida social." (HUNT, op.cit., p. 117).

${ }^{22}$ Artigo $1^{\circ}$. Todos os homens nascem igualmente livres e independentes, têm direitos certos, essenciais e naturais dos quais não podem, por nenhum contrato, privar nem despojar sua posteridade: tais são o direito de gozar a vida e a liberdade com os meios de adquirir e possuir propriedades, de procurar obter a felicidade e a segurança.

23 Pronunciamento de Thomas Jefferson em carta aos cidadãos republicanos do Condado de Washington, Maryland, em 31 de março de 1809 apud FERREIRA, Lauro César. Seguridade Social e Direitos Humanos. São Paulo: LTR, 2007. p. 27.

${ }^{24}$ ROCHA, op. cit., p. 29.

${ }^{25}$ ROCHA, op. cit., p. 29.
} 
exploração da classe trabalhadora. Com a livre iniciativa econômica, que visava, primordialmente, à acumulação de lucro, os direitos humanos já consagrados sofreram um grave revés.

Isso porque o crescimento econômico promovido pela Revolução Industrial contribuiu para a formação de uma imensa classe operária urbana, que crescia em progressão geométrica nos centros urbanos a fim de alcançar a única perspectiva de vida que lhe restava: vender sua força de trabalho. E a grande oferta de trabalhadores causou a diminuição do valor do trabalho, contribuindo para uma situação de miséria nos centros urbanos, que, aliás, sequer tinham infra-estrutura adequada para a manutenção de todos os trabalhadores.

Diante do quadro de miserabilidade da população e da ausência de observância dos direitos inerentes ao homem, esquecidos em consequência do individualismo capitalista, verificou-se a necessidade de uma atuação mais incisiva do Estado nas questões sociais, principalmente com o objetivo de realizar a igualdade e a justiça social.

De outro turno, as constantes reivindicações do movimento operário, que buscavam maior proteção à classe trabalhadora, em especial contra acidentes ocorridos em função do trabalho realizado, além de proteção à mulher e ao jovem trabalhador, fizeram com que o Estado tomasse à frente nas questões relativas aos direitos sociais.

Diante deste quadro vislumbra-se que

as consequências sociais da Revolução Industrial (...) foram sombrias. Por um lado, multiplicou-se enormemente a riqueza e o poderio econômico da burguesia. Por outro, desestruturou o modo tradicional de vida da população, tornando-o permanentemente instável, aprofundando dramaticamente as desigualdades sociais e fazendo tornarem-se familiares duas realidades terríveis: o desemprego e a alienação do trabalhador e relação ao seu produto. ${ }^{26}$

Uma nova concepção de Estado inicia-se por meio da busca à derrocada do capitalismo, defendido na época da Revolução Francesa como forma de ascender a burguesia ao poder. Com a verificação de que a Revolução significou apenas o triunfo de parte da burguesia - e justamente daquela parte que não era produtiva, mas que se restringia a viver de

\footnotetext{
${ }^{26}$ TRINDADE, op. cit., p. 85.
} 
especulação, rendas e aluguéis - e diante da iminente crise social acarretada pelos desmandos da visão capitalista, novos projetos são produzidos, sob a denominação de socialismo.

A insatisfação geral trouxe uma revolução social, cujo auge ocorreu em 1848, com a "Primavera dos Povos", impulso revolucionário orquestrado por operários que reivindicavam, em regiões da Europa central e ocidental, destacadamente na França, uma república democrática e social, insurgidos pelo Manifesto Comunista de Karl Marx ${ }^{27}$.

Dentro dessa ótica, a partir do desenvolvimento de constituições com garantias sociais, observa-se o surgimento do Estado Social de Direito, consagrando o reconhecimento dos direitos econômicos, sociais e culturais, de forma a atender aos trabalhadores e necessitados em geral. Para alguns doutrinadores, completa-se a segunda geração dos direitos humanos, com a garantia da proteção social.

A Constituição Francesa de 1848, vigente por apenas três anos, é considerada o marco para o início do reconhecimento dos direitos sociais. Sua redação revela o compromisso existente "entre o liberalismo e o socialismo democrático e entre os valores conservadores e o progresso e a civilização". ${ }^{28}$

A inserção significativa dos direitos sociais nas constituições mundiais, entretanto, inicia com a Constituição do México, promulgada em 1917. Esta carta trouxe uma sistematização pioneira no que diz respeito aos direitos sociais. Depois, a Constituição de Weimar, de 1919, promulgada após o fim da Primeira Guerra Mundial manteve o mesmo entendimento no que concerne à defesa dos direitos sociais.

\footnotetext{
${ }^{27}$ Para Marx, a burguesia operou uma extraordinária transformação estrutural na sociedade moderna. Em substituição aos antigos estamentos, típicos do feudalismo, no qual cada um possui seu próprio sistema de direitos e deveres, surgem as classes sociais, regidas por uma mesma lei geral, que lhes assegura a igualdade em direitos e deveres. No entendimento de Marx, essa é a verdadeira e fundamental liberdade burguesa. Porém, aponta o filósofo que essa divisão de classes sociais, surgida em decorrência da ascensão burguesa promove uma desigual repartição do único direito que realmente importa para a definição dos limites da vida individual na esfera privada e na esfera pública: a propriedade. E é essa repartição desigual da propriedade, promovida pelo capitalismo, que realiza a reificação dos homens, ou seja, a redução dos mesmos a meras coisas, com valor apreciável em dinheiro. Nesse sentido, os direitos humanos são violados, na medida em se admite a exploração do ser humano, em níveis degradantes, através da apropriação da mais-valia (mais alto grau da exploração do trabalho). Há uma desumanização dos trabalhadores, reduzidos à mera condição de mercadoria, cuja existência não tem dignidade, mas um preço. (COMPARATO, Fábio Konder. Ética: direito, moral e religião no mundo moderno. 2. ed. rev. São Paulo: Companhia das Letras, 2006).

${ }^{28}$ FERREIRA, op.cit., p. 35.
} 
Com esse novo entendimento, os direitos sociais passam a ser alçados a mesma categoria dos direitos civis, passando as normas constitucionais a ser entendidas como “portadoras de direitos subjetivos capazes de serem exercitáveis também frente ao legislador". 29

As duas Grandes Guerras ${ }^{30}$ também exerceram grande influência na concepção dos direitos humanos, principalmente os de cunho social. Após a Primeira Guerra Mundial, muitos países buscaram a organização do espaço social, através da gestão da miséria. A própria Conferência de Paz, realizada em Versalhes, em 1919, demonstrou uma grande preocupação com a questão social, principalmente com relação aos países que se sagraram perdedores no conflito.

Com o fim da Segunda Guerra Mundial, período no qual se observou um dos maiores genocídios da história mundial ${ }^{31}$, denota-se novamente uma preocupação com os direitos humanos. A Carta das Nações Unidas de 1945, criadora da Organização das Nações Unidas, "é um dos mais importantes documentos do século passado para o reconhecimento e desenvolvimento da concepção contemporânea dos direitos humanos". ${ }^{32}$ Isso porque, tendo surgido em decorrência da maior atrocidade já realizada contra a humanidade, visou à proteção global dos direitos humanos ${ }^{3334}$, através de uma organização política que abrangesse

\footnotetext{
${ }^{29}$ ROCHA, op. cit., p. 33.

${ }^{30}$ Primeira Guerra Mundial - 1914-1918 e Segunda Guerra Mundial - 1939-1945.

31 “O genocídio dos judeus não foi crime apenas contra o povo judeu. Ele foi crime contra a humanidade. Porque humanidade significa diversidade étnica e cultural, significa multiplicidade. Ao pretender decidir quais povos tinham o direito de habitar este planeta, os nazistas tentaram aniquilar a própria ideia de diversidade humana. $\mathrm{O}$ nazismo instaurou a possibilidade de destruir povos inteiros da face do planeta. (...) Na Polônia, mais de 500 comunidades judaicas foram destruídas. Em muitas destas comunidades, não restou um único sobrevivente. Na União Soviética, mais de 1,3 milhão de judeus foram assassinados e jogados de forma anônima em gigantescas valas. O número exato de mortos dificilmente será conhecido." (CYTRYNOWICZ, Roney. Memória da Barbárie: a história do genocídio dos judeu na segunda guerra mundial. $2^{\mathrm{a}}$ ed. São Paulo: Nova Stella: Editora da Universidade de São Paulo, 1991. p. 13-14).

${ }^{32}$ FERREIRA, op. cit., p. 43.

33 "A Carta das Nações Unidas de 1945 consolida o movimento de internacionalização dos direitos humanos, a partir do consenso de Estados que elevam a promoção desses direitos a propósito e finalidade das Nações Unidas. Definitivamente, a relação de um Estado com os seus nacionais passa a ser uma problemática internacional, objeto de instituições internacionais e do Direito internacional.” (PIOVESAN, Flávia. Direitos Humanos e Direito Constitucional Internacional. $3^{\text {a }}$ ed. atual. São Paulo: Max Limonad, 1997. p. 152).

${ }^{34}$ Hannah Arendt, ao analisar a questão dos direitos humanos, aponta que a humanidade (dignidade) do ser humano é perdida quando este é afastado de sua comunidade. Isso ocorre porque a medida da existência da dignidade humana é a participação em uma comunidade que garanta e proteja o direito de ter direitos (viver em uma estrutura em que suas ações e opiniões são consideradas). "O paradoxo da perda dos direitos humanos é que essa perda coincide com o instante em que a pessoa se torna um ser humano em geral - sem uma profissão, sem uma cidadania, sem uma opinião, sem uma ação pela qual se identifique e se especifique - e diferente em geral, representando nada além da sua individualidade absoluta e singular que, privada da expressa e da ação sobre um mundo comum, perde todo o seu significado. Assim, por mais bem intencionadas que sejam as formulações de
} 
todas as nações do mundo, com o objetivo de defender a dignidade humana, manter a paz e a segurança internacionais.

Muito embora se observe que a Carta da ONU tenha adotado uma linguagem vaga e aberta no que concerne à definição de direitos humanos e liberdades fundamentais, o que realmente importa é que seus dispositivos internacionalizaram os direitos humanos, fazendo com que os Estados-partes reconheçam tais direitos. ${ }^{35}$

Na sequência da proteção dos direitos humanos, foi adotada, em 10 de dezembro de 1948, a Declaração Universal dos Direitos Humanos. Esse documento inovou ao promover a combinação dos primados da cidadania com os primados sociais, passando a elencar tanto direitos civis e políticos como direitos sociais, econômicos e culturais.

Essa conjugação de valores demarca a concepção contemporânea de direitos humanos, na qual "esses direitos passam a ser concebidos como uma unidade interdependente e indivisivel". ${ }^{36}$ Demonstra-se, com essa ideia, a interação das chamadas "gerações" de direitos humanos e não sua simples substituição.

A proteção aos direitos humanos, foi, deste modo, elevada à categoria de temática internacional, deixando de ser matéria pertinente a um ou outro Estado. Ou seja, os direitos humanos passaram a ser considerados direitos universais, devendo alcançar todas as pessoas, sem distinção de sexo, raça, origem nacional, ocupação, religião ou qualquer outro comprometimento.

A partir da década de 1970, a comunidade mundial deparou-se com uma nova realidade econômica. Surgem novas tecnologias, que começam a ser usadas para o aumento da produção. E a economia passa a ser globalizada, ou seja, o capital deixa de pertencer a um único Estado, uma vez que a produção pode ser realizada em diversas partes.

declarações de direitos humanos realizadas pelas organizações internacionais, o problema da humanidade transcende à esfera da lei internacional, que ainda funciona em termos de acordos e tratados recíprocos entre Estados soberanos; e, por enquanto não existe uma esfera superior às nações. Além disso, o dilema não seria resolvido pela criação de um "governo mundial"”. (ARENDT, Hannah. As Origens do Totalitarismo. II Imperialismo, a expansão do poder. Rio de Janeiro: Editora Documentário, 1976).

${ }^{35}$ PIOVESAN, op. cit., p. 153.

${ }^{36}$ Ibid., p 159. 
Diante desse novo quadro, uma nova forma de direito começa a ser moldada: surge a chamada terceira geração dos direitos humanos, consubstanciada pelos direitos difusos.

São direitos difusos todos aqueles nos quais é impossível determinar seu titular. São "interesses ou direitos transindividuais, de natureza indivisível, de que sejam titulares pessoas indeterminadas e ligadas por circunstâncias de fato". ${ }^{37}$

A ideia de globalização repercute intensamente na concepção dos direitos. Diante da imagem de um mundo sem fronteiras, os direitos supranacionais passaram a ter um maior destaque, como a proteção ao meio-ambiente, as questões relativas ao consumidor e ao patrimônio cultural, público e social.

Por outro turno, o crescimento da globalização tem promovido a redução da proteção social, na medida em que "o capitalismo mundial parece não estar mais disposto a tolerar os gastos despendidos com a promoção do bem comum". ${ }^{38}$ Verifica-se uma nova concepção de liberalismo, com a interferência mínima do Estado nas questões sociais em prol do crescimento econômico.

De todo modo, os direitos humanos de cunho individual, social e difuso são hoje internacionalmente previstos. A questão que se insurge, agora, não é mais, portanto, de justificá-los, mas, sim, de protegê-los. E isso não é um problema filosófico, é um problema político. $^{39}$

\subsection{Os direitos humanos e a dignidade da pessoa humana}

Verificada a questão dos momentos históricos de reconhecimento dos direitos humanos, faz-se necessária uma análise mais aprofundada de sua intrínseca relação com a dignidade da pessoa humana, e os fundamentos dessa relação.

Durante todo o período histórico no qual os direitos humanos foram, paulatinamente, reconhecidos, surgiram questionamentos acerca de seus fundamentos, ou seja, acerca dos

\footnotetext{
${ }^{37}$ MAZZILli, Hugo Nigro. A Defesa dos Interesses Difusos em Juizo. 15. ed. rev. atual. e ampl. São Paulo: Saraiva, 2002. p. 46.

${ }^{38}$ ROCHA, op. cit., p. 41.

${ }^{39}$ BOBBIO, Norberto. A Era dos Direitos. nova ed. $5^{\text {a }}$ reimpressão. Rio de Janeiro: Elsevier, 2004.p. 43.
} 
motivos que justificaram determinada escolha. Em suma: a razão pela qual determinado direito, em determinada época, era essencial ao homem em busca pela dignidade.

Conforme salientado no item anterior, as modificações havidas no decorrer da história, no que concerne à interiorização do reconhecimento ao semelhante como igual, foram fruto de sofrimentos morais e dissabores físicos, reflexos de violências, torturas, massacres, que fizeram com que se buscassem novas regras de respeito e, por conseguinte, direitos, em prol de uma vida digna para todos ${ }^{40}$.

Em uma concepção jusnaturalista, são direitos humanos todos aqueles inerentes à condição humana, cujo principal objetivo é a busca pela dignidade.

A problemática inicial se concentra naquilo que se reconhece como dignidade. Em sentido literal, dignidade significa "consciência do próprio valor; honra; modo de proceder que inspira respeito; distinção". 41

A dignidade da pessoa humana é, no entanto, um conceito que remonta a estudos durante séculos. Isso porque, não obstante sua definição analítica específica, a dignidade apresenta uma carga semântica indeterminada, ou seja, um núcleo abstrato, permitindo juízos valorativos.

A primeira noção de dignidade adveio com a crença religiosa trazida pelo monoteísmo, sendo considerada a partir de uma semelhança divina, o que garantia a igualdade entre todos os seres humanos. Por essa perspectiva, o reconhecimento da dignidade se confundia com o conceito de igualdade: se todos os homens foram concebidos à imagem e à semelhança de Deus, natural todos serem iguais e todos terem direito a uma vida digna.

Dentro da Filosofia Cristã, o maior destaque é dado a São Tomás de Aquino, que foi o primeiro a tratar efetivamente sobre a questão da dignidade da pessoa humana, contribuindo para um conceito moderno de dignidade na era cristã medieval. Seus estudos apontam para o

\footnotetext{
${ }^{40}$ COMPARATO, Fábio Konder. Afirmação Histórica dos Direito Humanos. $7^{\mathrm{a}}$ ed. rev. e atual. São Paulo: Saraiva, 2010. p. 50.

${ }^{41}$ HOUAISS, Antonio e VILLAR, Mauro de Salles. Minidicionário Houaiss da língua portuguesa. 3. ed. rev. e aum. Rio de Janeiro: Objetiva, 2009. p. 250.
} 
entendimento de que o homem é formado pela união substancial entre dois corpos, material (corpo) e espiritual (alma), fundamento maior da dignidade humana.

Com a racionalização do direito, porém, o próprio conceito de pessoa sofreu alterações, através de manifestação de Descartes ${ }^{42}, \operatorname{Hobbes}^{43}$, Locke $^{44}$ e, em especial Kant. Por meio da nova conceituação de pessoa, novos parâmetros para o entendimento da dignidade se descortinaram.

O significado e o conteúdo de dignidade, tal qual é conhecido hoje, foi influenciado pelo pensamento do filósofo alemão Immanuel Kant. Por esta razão, é frequente a indicação de Kant como o enunciador do princípio da dignidade humana.

Isso ocorreu porque Kant foi o primeiro estudioso a reconhecer a valorização do ser humano, apontando o homem como um fim em si mesmo, possuidor de valor absoluto, não lhe sendo possível atribuir preço ou substituí-lo por equivalente.

Seu pensamento trouxe, para a filosofia dos direitos humanos, a herança da igualdade na distribuição da dignidade. A partir da premissa de que a razão prática é determinada pela liberdade, esta liberdade passa a ser o requisito básico para a dignidade do ser humano e para que todos os que detêm a condição humana gozem de autonomia e autodeterminação.

Atualmente, entende-se dignidade da pessoa humana como valor máximo, supremo, fonte jurídico-positiva dos direitos humanos, na medida em que "constitui elemento que qualifica o ser humano como tal e dele não pode ser destacado". ${ }^{45}$ É esse valor que se impõe como núcleo basilar e organizador de toda e qualquer ordem jurídica ${ }^{46}$, que nele encontra seu próprio sentido, de forma a garantir o respeito à integridade física, emocional, moral, psíquica e espiritual das pessoas através do livre aprimoramento da personalidade.

\footnotetext{
${ }^{42}$ Renée DESCARTES, a partir de um método dedutivo (pesquisa e análise), conceitua homem como aquele com capacidade de pensar ("penso, logo existo").

${ }^{43}$ Thomas HOBBES, adotando um método indutivo, típico dos empiristas, explica pessoa como o ser racional que é capaz de adequar os meios aos fins, em busca da satisfação de suas paixões.

44 John LOCKE, empirista que também baseia a concepção de homem na avaliação das experiências e nas relações interpessoais, define pessoa como um ser pensante, autoconsciente e capaz de reconhecer-se como responsável e controlador de suas ações passadas e futuras.

${ }^{45}$ SARLET, Ingo Wolfgang. A Eficácia dos Direitos Fundamentais: uma teoria geral dos direitos fundamentais na perspectiva constitucional. 10. ed. rev., atual. e ampl. Porto Alegre: Livraria do Advogado, 2009. p. 101.

${ }^{46}$ PIOVESAN, op. cit., p. 60.
} 


\subsection{Da concepção dos direitos humanos (individuais e sociais) como direitos fundamentais}

O surgimento dos direitos humanos fundamentais ocorreu com a fusão de várias fontes, desde tradições arraigadas nas diversas civilizações até a conjugação de pensamentos filosófico-jurídicos, das idéias advindas do cristianismo e com o direito natural. Todas essas fontes culminavam em um ponto em comum: a necessidade de limitação e controle dos abusos do poder do Estado e de suas autoridades constituídas, além da consagração dos princípios básicos da igualdade e da legalidade como regentes do Estado moderno e contemporâneo.

A noção de direitos fundamentais consagrou a necessidade de se esculpir um rol mínimo de direitos humanos em um documento escrito, colocando-se como uma das previsões obrigatórias a todas as Constituições, no sentido de promover o respeito à dignidade humana, garantir a limitação do poder e visar ao pleno desenvolvimento da personalidade humana.

Conforme já mencionado, foi por meio da Declaração Universal dos Direitos Humanos de 1948 que houve o reconhecimento e a proteção internacional dos direitos humanos. E também, foi através desse documento histórico que os Estados passaram a modificar seu pensamento acerca dos direitos humanos.

Diante da marca trazida pela $2^{\mathrm{a}}$ Guerra Mundial, na qual o Estado é o culpado pelo maior genocídio de civis já visto na história da humanidade, surge a "necessidade de reconstrução do valor dos direitos humanos, como paradigma e referencial ético a orientar a ordem internacional". ${ }^{47}$ Ou seja, faz-se necessária a adoção de uma nova concepção de direitos humanos, apta a promover sua preservação e garantir sua eficácia.

A Declaração Universal dos Direitos Humanos de 1948, ao promover a mudança no modo de pensar no que concerne a esses direitos, trouxe uma concepção contemporânea de

\footnotetext{
${ }^{47}$ PIOVESAN, Flávia. A proteção dos direitos sociais nos planos interno e internacional. Direito Previdenciário e Constituição. São Paulo: LTr, 2004. p. 14.
} 
deles, de forma a orientar uma nova ordem internacional, que passa a ter como objetivo precípuo a proteção dos referidos direitos humanos.

Nesse sentido, a Declaração de 1948 foi o instrumento hábil para fortalecer a ideia de que a proteção dos direitos humanos não deve ficar restrita ao domínio exclusivo e à competência e jurisdição interna do Estado.

Daí a primeira consequência da concepção contemporânea de direitos humanos: a soberania absoluta do Estado passa a sofrer um processo de relativização, sendo autorizadas intervenções no plano nacional a fim de resguardar os direitos humanos. ${ }^{48}$

Por este entendimento, todos os Estados que ratificaram a Declaração estão sujeitos à observância dos princípios dos direitos humanos em suas relações internas, sob pena de intervenção dos órgãos internacionais. Ou seja, os princípios de direitos humanos devem ser positivados dentro do ordenamento jurídico de cada país e estritamente observados e protegidos.

Não obstante a proteção internacional prevista, os direitos humanos também devem ter alcance universal, isto é, devem alcançar todas as pessoas. A condição de pessoa, neste caso, é o único requisito necessário para a titularidade de tais direitos, independentemente de raça, sexo, etnia, condição social, ocupação, religião ou ideologia. Assim sendo, basta ser pessoa para ser titular de direitos humanos e ter dignidade humana.

Insta ressaltar que a questão da universalidade dos direitos humanos foi reafirmada na Declaração de Viena de $1993^{49}$, na qual foi reforçada "a ideia de proteção integral de todos os seres humanos, independente do sistema cultural, religioso e ideológico em que vivem, e (...) a ideia do ser humano como sujeito de direitos humanos". ${ }^{50}$ Observa-se, assim, a segunda consequência da nova concepção dos direitos humanos.

\footnotetext{
${ }^{48}$ Ibid., p. 15.

${ }^{49}$ A Conferência Mundial sobre Direitos do Homem reafirma o empenhamento solene de todos os Estados em cumprirem as suas obrigações no tocante à promoção do respeito universal, da observância e da proteção de todos os direitos do homem e liberdades fundamentais para todos, em conformidade com a Carta das Nações Unidas, com outros instrumentos relacionados com os Direitos do homem e com o direito internacional. A natureza universal destes direitos e liberdades é inquestionável. (Parágrafo $1^{\circ}$ da Declaração de Viena e Programa de Ação - Conferência Mundial dos Direitos do Homem, Viena, 14-25 de junho de 1993).

${ }^{50}$ FERREIRA, op. cit., p. 77.
} 
A Declaração Universal de 1948 também traduziu entendimento de que, além de universais, os direitos humanos formam uma unidade indivisível, interdependente e interrelacionada, nos quais uns devem ser analisados em conjunto com os outros, a fim de produzir maior eficácia. Deste modo, os direitos relativos à cidadania (civis e políticos) foram conjugados aos direitos sociais, econômicos e culturais, de uma forma jamais vista anteriormente.

A interação entre as diversas facetas dos direitos humanos permite uma melhor proteção de seus princípios, além de garantir uma maior eficácia na preservação da dignidade da pessoa humana.

Ademais, a integração dos direitos civis e políticos com os direitos humanos sociais, econômicos e culturais afasta a errônea defesa de que as gerações de direitos humanos se substituem no tempo, de acordo com o período histórico apresentado. Essa conjugação apenas corrobora a idéia de que os direitos humanos são, a cada geração, cumulados e fortalecidos, através da complementação de valores e da dinâmica da própria interação. ${ }^{51}$

Nesse sentido, brilhante a explanação de Flávia Piovesan: ${ }^{52}$

Vale dizer, sem a efetividade dos direitos econômicos, sociais e culturais, os direitos civis e políticos se reduzem a meras categorias formais, enquanto que, sem a realização dos direitos civis e políticos, ou seja, sem a efetividade da liberdade entendida em seu mais amplo sentido, os direitos econômicos, sociais e culturais carecem de verdadeira significação. Não há mais como cogitar da liberdade divorciada da justiça social, como também infrutífero pensar na justiça social divorciada da liberdade. Em suma, todos os direitos humanos constituem um complexo integral, único e indivisível, em que os diferentes direitos estão necessariamente inter-relacionados e são interdependentes entre si.

Diante da busca pela dignidade da pessoa humana, princípio maior dos direitos humanos, denota-se a necessidade da conjugação dos valores civis, políticos, sociais, econômicos e culturais para a completa proteção da pessoa. Essa inovação trazida pela Declaração de 1948 prevê que não há liberdade sem igualdade, assim como não há igualdade

\footnotetext{
${ }^{51}$ PIOVESAN, Flávia. Direitos Humanos e o Direito Constitucional Internacional. $3^{\text {a }}$ edição atualizada. São Paulo: Max Limonad, 1997. p 160.

${ }^{52}$ Ibid., p. 161.
} 
sem liberdade. "Não é possível pensar em liberdade sem justiça social e justiça social sem liberdade". 53

Aliás, a Declaração de Viena também corroborou esse entendimento ao estabelecer em sua redação a indivisibilidade e a interdependência do conceito e do conteúdo dos direitos humanos. ${ }^{54}$

Em razão da indivisibilidade dos direitos humanos não há o que se falar em distinção no reconhecimento nas classes de direitos. Deve ser superada a posição de que a classe dos direitos relativos à cidadania (civis e políticos) merece maior proteção e respeito do que a classe dos direitos sociais, econômicos e culturais. Até mesmo porque, sob a ótica normativa internacional, os direitos sociais, econômicos e culturais são considerados direitos legais, sendo acionáveis, exigíveis e que demandam estrita observância. ${ }^{55}$

A conjugação desses direitos, no entanto, apresenta dificuldade, principalmente, nos países em desenvolvimento, nos quais a implementação de projetos de proteção aos direitos sociais, econômicos e culturais encontra entrave em consequência de divergências políticas e/ou econômicas.

Em razão da nova concepção de direitos humanos trazida pela Declaração de 1948 e corroborada pela Declaração de Viena de 1993, cabe também à comunidade internacional a criação de "políticas universais capazes de integrar o desenvolvimento, a democracia e os direitos humanos, necessários para a preservação do fim último, que é a preservação da dignidade humana". 56

\subsection{Das normas de direitos fundamentais}

\footnotetext{
${ }^{53}$ FERREIRA, op. cit., p. 81.

${ }^{54}$ Todos os Direitos do homem são universais, indivisíveis, interdependentes e inter-relacionados. A comunidade internacional tem de considerar globalmente os Direitos do homem, de forma justa e eqüitativa e com igual ênfase. Embora se devam ter sempre presente o significado das especificidades nacionais e regionais e os antecedentes históricos, culturais e religiosos, compete aos Estados, independentemente dos seus sistemas político, econômico e cultural, promover e proteger todos os Direitos do homem e liberdades fundamentais. (Parágrafo $5^{\circ}$ da Declaração de Viena e Programa de Ação - Conferência Mundial dos Direitos do Homem, Viena, 14-25 de junho de 1993).

${ }^{55}$ PIOVESAN, Flávia. A proteção dos direitos sociais nos planos interno e internacional. Direito Previdenciário e Constituição. São Paulo: LTr, 2004. p. 54.

${ }^{56}$ FERREIRA, op. cit., p. 82.
} 
A partir da verificação da importância dos direitos fundamentais em um contexto contemporâneo, importa a análise da forma de apresentação desses direitos: as normas de direitos fundamentais.

Antes de analisar a norma de direitos fundamentais propriamente dita, importante se faz esclarecer que a importância de tais normas decorre da existência de uma Constituição com força normativa ${ }^{57}$, base fundamentadora de um ordenamento jurídico. Ou seja, as normas de direitos fundamentais somente terão eficácia se a Constituição que as estabelecer sintetizar uma realidade concreta de seu tempo e se as tarefas por ela impostas refletirem a vontade (consciência geral) de concretizar uma ordem jurídica.

Nas palavras de Alexy ${ }^{58}$,"normas de direitos fundamentais são normas."Por serem imprescindíveis para a proteção da dignidade humana, as normas de direitos fundamentais garantem a existência de um direito fundamental.

Dentro dessa perspectiva, um aspecto importante para a teoria dos direitos fundamentais é a distinção entre regras e princípios. ${ }^{59}$ Muito embora não se trate de uma discussão nova, é uma questão que ainda desperta divergências entre os doutrinadores.

Há aqueles que sustentam que a distinção entre regras e princípios baseia-se em uma diferença de grau: princípios seriam as normas mais importantes do ordenamento jurídico, enquanto que as regras concretizariam tais princípios. Outros defendem a divergência a partir do grau de abstração: princípios se apresentariam de forma mais geral e abstrata do que as regras. ${ }^{60}$

Não obstante as explicações sobre as diferenças, fato é que tanto princípios quanto regras são normas, na medida em que enunciam o dever-ser. Trata-se, pois, de uma distinção entre duas modalidades de normas.

\footnotetext{
${ }^{57}$ HESS, Konrad. A Força Normativa da Constituição. Porto Alegre: Sérgio Fabris Editor, 1991.

${ }^{58}$ ALEXY, Robert. Teoria dos Direitos Fundamentais. Trad. Virgílio Afonso da Silva. São Paulo: Malheiros, 2008. p. 51.

59 "Essa distinção é a base da teoria da fundamentação no âmbito dos direitos fundamentais e uma chave para a solução dos problemas centrais da dogmática dos direitos fundamentais. Sem ela não pode haver nem uma teoria adequada sobre as restrições a direitos fundamentais, nem uma doutrina satisfatória sobre colisões, nem uma teoria suficiente sobre o papel dos direitos fundamentais no sistema jurídico". (Ibid., p. 85)

${ }^{60}$ SILVA, Virgílio Afonso da. Direitos Fundamentais: conteúdo essencial, restrições e eficácia. $2^{\mathrm{a}}$ ed. São Paulo: Malheiros, 2010. p. 44.
} 
Em um primeiro momento, observa-se que a distinção entre princípios e normas pode ser verificada a partir de uma ótica lógica. Segundo Ronald Dworkin:

Os dois conjuntos de padrões apontam para decisões particulares acerca da obrigação jurídica em circunstâncias específicas, mas distinguem-se quanto à natureza da orientação que oferecem. ${ }^{61}$

Já Canotilho estabelece a proposição de critérios para auxiliar a distinção entre princípios e regras. Resolve a divergência a partir (i) do grau de abstração, sendo os princípios normas com grau maior de abstração do que as regras; (ii) do grau de determinação na aplicação do caso concreto, na medida em que os princípios prescindem de uma mediação concretizadora enquanto que as regras são diretamente aplicáveis; (iii) do caráter de fundamentalidade do sistema, já que os princípios são fundamentais por corresponderem à estrutura do sistema jurídico, enquanto que as regras desenvolvem-se a partir dos princípios; (iv) da proximidade da ideia de direito, sendo os princípios standards que traduzem ideias de justiça e de direito e as regras vinculadas ao seu conteúdo meramente funcional; e, por fim, (v) da natureza normogenética, uma vez que os princípios são fundamentos das regras. ${ }^{62}$

A distinção entre regras e princípios, a partir de uma teoria dos princípios ${ }^{63}$, é baseada na análise da estrutura dos direitos garantidos pela norma. Afasta-se, assim, uma diferença gradual e apresenta-se uma diferença qualitativa.

Princípios são normas consideradas como mandamentos de otimização, na medida em que podem ser satisfeitos em graus variados, porém, visando sempre à realização máxima. Ou seja, não dependem de uma realização total e completa para sua eficácia, mas "ordenam que algo seja realizado na maior medida possível dentro das possibilidades jurídicas e fáticas existentes". ${ }^{64}$ Assim, princípios garantem direitos (ou impõem deveres) prima facie.

\footnotetext{
${ }^{61}$ DWORKIN, Ronald. Levando os direitos a sério. 2. ed. São Paulo: Martins Fontes, 2007. p. 39.

${ }^{62}$ CANOTILHO José Joaquim Gomes. Direito Constitucional e Teoria da Constituição. $7^{\mathrm{a}}$ ed. 8. reimp. Coimbra: Almedina, 2003. p. 1160-1161.

${ }^{63}$ Distinção defendida por Robert Alexy e Virgílio Afonso da Silva.

${ }^{64}$ ALEXY, op. cit., p. 90.
} 
Mesmo os princípios cujos enunciados se assemelham a regras não apresentam consequências jurídicas automáticas diante das circunstâncias apresentadas. ${ }^{65}$

Por outro lado, regras são normas que se submetem à definitividade do direito garantido (ou dever imposto). Portanto, o direito nela previsto deve ser plenamente satisfeito para sua eficácia. É a regra do tudo ou nada: para a validade da regra, deve ser feito exatamente aquilo que ela exige. "Regras contém, portanto, determinações no âmbito daquilo que é fática e juridicamente possível.",66

Em contrapartida aos princípios, inclusive, às regras são admitidas exceções, devendo estas estar enumeradas no respectivo enunciado, sob pena de ser considerado incompleto ou impreciso. $^{67}$

A melhor forma de se verificar a questão da diferença entre regras e princípios, dentro da teoria dos princípios, é a partir dos conflitos normativos (colisões entre princípios e conflitos entre regras).

No caso das regras, na qual se impõe a definitividade dos direitos (ou deveres) e o raciocínio do tudo ou nada, a solução encontrada é a adoção de cláusula de exceção ou a declaração de invalidade de uma das normas conflitantes, no todo ou em parte.

Ou seja, quando se tem uma regra, não há graduação na sua validade. Não podem existir duas regras incompatíveis em razão de enunciados conflitantes. Deste modo, o conflito entre regras deve ser resolvido pela adoção de alguma exceção à regra existente ou no âmbito da validade da norma. ${ }^{68}$

Quanto se trata de princípios, as colisões são resolvidas de forma diferenciada, na medida em que apresentam uma dimensão de peso e de importância distinta das regras, cuja funcionalidade é que rege a respectiva importância. ${ }^{69}$ Como os princípios são mandamentos

\footnotetext{
${ }^{65}$ DWORKIN, op. cit., p. 40.

${ }^{66}$ ALEXY, op. cit., p. 81.

${ }^{67}$ DWORKIN, op. cit., p. 40.

68 "Sempre que há conflito entre regras, há alguma forma de declaração de invalidade. (...) Isso porque é possível reconstruir o primeiro exemplo - a instituição de uma cláusula de exceção - como uma declaração parcial de invalidade". (SILVA, op. cit., p. 49).

${ }^{69}$ DWORKIN, op. cit., p. 42-43.
} 
de otimização que exigem que algo seja realizado da melhor maneira possível diante das condições jurídicas e fáticas existentes, um dos princípios terá que ceder, a partir de relações condicionadas de precedência. $^{70}$

Pela necessidade de compatibilização entre os princípios, já que expressam direitos prima facie, conflitos devem ser resolvidos através do sopesamento (cotejo) entre os interesses conflitantes. E a função desse cotejo é justamente definir qual dos interesses em conflito - "que, abstratamente, estão no mesmo nível"71 - tem maior peso no caso concreto.

Ao contrário do que ocorre com o conflito entre regras, no qual a declaração de invalidade (total ou parcial) é medida necessária para a resolução, no caso dos princípios, a colisão é resolvida pela análise do caso concreto, em um sopesamento do interesse que, diante de circunstâncias fáticas e jurídicas específicas, apresenta uma importância maior e precedência perante o princípio conflitante.

Verifica-se, pois, que a determinação para a prevalência de um princípio sobre o outro, em uma determinada circunstância concreta, são as condições que essa circunstância apresenta. Assim, dois princípios conflitantes podem apresentar prevalência alternada de um sobre o outro conforme as condições fixadas em cada caso concreto.

Conflitos entre regras ocorrem na dimensão das validade, enquanto as colisões entre princípios - visto que só princípios válidos podem colidir ocorrem, para além dessa dimensão, na dimensão do peso. ${ }^{72}$

Não há, no caso dos princípios, relações incondicionadas de precedência. Não há existência de princípios absolutos, haja vista que não refletem direitos (ou deveres) definitivos. O resultado das eventuais colisões entre princípios será realizado, por consequência, a partir de análise das circunstâncias fáticas e jurídicas envolvidas em cada caso concreto, garantindo a prevalência de um ou outro conforme o interesse de maior peso.

Por fim, em um corolário lógico da análise das duas espécies de normas, princípios e regras, tem-se a verificação da possibilidade de colisão entre princípios e regras.

\footnotetext{
${ }^{70}$ SILVA, op. cit., p. 50.

${ }^{71}$ ALEXY, op. cit., p. 95.

${ }^{72}$ Ibid., p. 94.
} 
Normalmente, não se pode mencionar um cotejo entre princípios e normas, justamente por se encontrarem em níveis qualitativos diversos. Na realidade, o que se verifica é que a regra é o produto do sopesamento, produzido pelo legislador, de dois princípios que garantem direitos fundamentais (prima facie). "A relação entre a regra e um dos princípios não é, portanto, uma relação de colisão, mas uma relação de restrição. A regra é a expressão dessa restrição. Essa regra deve, portanto, ser simplesmente aplicada por subsunção". 73

\subsection{A questão da limitação (e da restrição) aos direitos humanos fundamentais}

Após análise da definição e fundamentação dos direitos fundamentais, faz-se necessário, para o desenvolvimento do presente estudo, a apreciação das questões que envolvam a existência de limitação ou de restrição (conforme a teoria adotada) dos mesmos.

Quando se fala em direitos, é natural que se presuma a existência de restrições e de limitações, sejam implícitas ou explícitas. O problema surge quando a questão envolve direitos fundamentais, em sua síntese, essenciais à dignidade humana.

A extensão do âmbito de proteção dos direitos fundamentais, como reflexo da amplitude das necessidades humanas, leva a uma consequente colisão desses direitos entre si e com outros interesses constitucionais e a redução dos mesmos em determinadas situações concretas. $^{74}$

Nessa sequência, a fim de verificar a questão da restrição (ou da limitação) dos direitos humanos fundamentais, importante se faz ressaltar a definição dos conteúdos e extensões dessas reduções. $^{75}$

Duas teorias cuidam de explicar a relação entre os direitos e seus limites e extensões: a teoria interna e a teoria externa ${ }^{76}$. Essas teorias já são utilizadas no âmbito do direito civil,

\footnotetext{
${ }^{73}$ SILVA, op. cit., p. 52.

${ }^{74}$ SILVA, op. cit., p. 126.

${ }^{75}$ ALEXY, op. cit., p. 276.

76 "Saber se correta é a teoria externa ou a teoria interna é algo que depende essencialmente da concepção de normas de direitos fundamentais como regras ou como princípios, ou seja, da concepção das posições de direitos fundamentais como posições definitivas ou prima facie. Se se parte de posições definitivas, então, a teoria
} 
muito embora não sejam objeto de estudos aprofundados no Brasil, principalmente, no que concerne à temática dos direitos fundamentais. ${ }^{77}$

De acordo com a teoria interna, a definição dos limites dos direitos (fundamentais ou não) é inerente ao próprio direito. Ou seja, os limites de um direito são limites imanentes, fixados por um processo interno, sem qualquer influência ou determinação de aspectos externos. Nessa medida, afasta-se a concepção de colisões com outros direitos.

Para os defensores da teoria interna, cada direito possui seu próprio conteúdo, definido de antemão, e estabelece suas próprias limitações. ${ }^{7879}$ Deste modo, não há o que se falar em sopesamento de direitos, nem em critérios de razoabilidade ou proporcionalidade, haja vista que os direitos fundamentais já apresentam seus limites previamente definidos, seja de forma implícita ou explícita, pela própria Constituição. ${ }^{80}$

Os direitos fundamentais não são, pois, direitos absolutos. Mas essa conclusão, pela teoria interna, advém do entendimento da existência de limites imanentes, os quais tão somente declaram limites previamente existentes.

Por outro lado, a teoria interna ainda justifica a limitação dos direitos fundamentais pelo que se reconhece como teoria institucional de Peter Häberle ${ }^{81}$, na qual as ideias de

externa pode ser refutada; se se parte de posições prima facie, então, é a teoria interna que o pode ser”. (ALEXY, op. cit., p. 278)

${ }^{77}$ SILVA, op. cit., p. 127.

${ }^{78}$ Nesse caso, não se usa a expressão "restrição", haja vista que o direito não se restringe a si próprio, mas apenas se limita a uma maior ou menor abrangência em determinadas circunstâncias. Nessa linha: "a opção pelo termo "limite", como se mencionou anteriormente, é proposital, já que se pretende denotar - como salienta o próprio Vieira de Andrade - que, nesses casos, não se deve falar em restrições aos direitos fundamentais ou colisões entre eles, mas de meros limites que decorrem da própria constituição. Nesse sentido, é comum dizer que tais limites fazem parte da própria essência dos direitos fundamentais, já que não se pode falar em liberdades ou em direitos limitados e que é tarefa por excelência da interpretação constitucional tornar seus contornos os mais claros possíveis."'( SILVA, op. cit., p. 132).

${ }^{79}$ Cf. ALEXY, op. cit., p. 277-278: "Um cenário completamente diferente é a base de sustentação da teoria interna. Segundo ela, não há duas coisas - o direito e sua restrição -, mas apenas uma: o direito com um determinado conteúdo. O conceito de restrição é substituído pelo conceito de limite. Dúvidas acerca dos limites do direito não são dúvidas sobre quão extensa pode ser sua restrição, mas dúvidas sobre seu conteúdo. Quando eventualmente se fala em "restrições" no lugar de "limites", então se fala em "restrições imanentes","

${ }^{80}$ SILVA, op. cit., p. 131.

${ }^{81}$ Constitucionalista alemão que, inspirado nas ideias de Hariou (conceito de instituição, que se baseia "em três elementos principais: (1) ideia diretriz que se realiza e permanece juridicamente em um meio social; (2) para a realização dessa ideia, organiza-se um poder que lhe confere órgãos; (3) entre os membros do grupo social interessado na realização dessa ideia surgem manifestações de comunhão dirigidas pelos órgãos de poder e reguladas por procedimentos)", desenvolveu teoria para explicar a questão dos limites dos direitos fundamentais e de seu conteúdo essencial. (SILVA, op. cit., p. 134-135). 
direitos fundamentais "realidade social ao mesmo tempo que também a definem. Dentro dessa perspectiva, ao serem considerados institutos, os direitos fundamentais, "como liberdade, personalidade, propriedade, são internalizados pelo Direito, sendo criados pela própria atividade estatal que, previamente, além de garantir sua observância, já estabelece seus limites" 82

Tem-se, portanto, a partir dessa teoria, uma noção dos direitos fundamentais como posições definitivas - regras -, sujeitas ao raciocínio do "tudo ou nada". Os limites são préestabelecidos. Já se sabe, de antemão, o âmbito de atuação dos direitos fundamentais.

Em suma: ao considerar as limitações dos direitos fundamentais como algo inerente ao próprio direito, afasta-se a necessidade de avaliação, em cada caso concreto, da supremacia de um direito sobre o outro. Prevalecendo uma posição definitiva, não cabe o cotejo de direitos fundamentais em situações específicas concretas.

A teoria externa, ao contrário da anterior, na qual o direito e seus respectivos limites são vistos como uma unidade, divide esse objeto em duas partes: o direito propriamente dito (em si) e, à parte desse direito, suas restrições. ${ }^{83}$

Nesse sentido, as restrições aos direitos fundamentais não atingem o conteúdo do direito em si, mas tão somente afetam o exercício de tais direitos. Deste modo, nessa hipótese, pode-se sustentar uma colisão de direitos, vigendo, em cada situação concreta, aquele que reflete, de forma mais aguda, a proteção à dignidade humana.

Vislumbrando a teoria externa, denota-se uma relação estreita entre a mesma e a teoria dos princípios. Isso porque, pela teoria dos princípios, os "direitos fundamentais são garantidos por uma norma que consagra um direito prima facie" ${ }^{84} \mathrm{E}$ são justamente essas normas que constituem as restrições aos direitos fundamentais, garantidos pelos respectivos princípios. $^{85}$

\footnotetext{
${ }^{82}$ Ibid., p. 137.

${ }^{83}$ SILVA, op. cit., p. 137.

${ }^{84}$ SILVA, op. cit., p. 139.

${ }^{85}$ Restrições a direitos fundamentais são normas que restringem a realização de princípios de direito fundamental. $O$ que significa restringir a realização de um princípio de direito fundamental é algo demonstrado de forma paradigmática por meio das normas mandatórias e proibitivas. (ALEXY, op. cit., p. 285)
} 
Os princípios garantidores de direitos fundamentais são, em síntese, ilimitados (prima facie). Porém, por não serem absolutos, são passíveis de restrições por princípios colidentes. Deste modo, não podem ser considerados como direitos definitivos (regra do tudo ou nada). E é exatamente essa posição que a teoria externa pressupõe.

Dentro da teoria externa, em um aspecto material, as restrições a direitos fundamentais baseiam-se em colisão de princípios, na medida em que se realizam através da solução encontrada, qual seja, a escolha de um deles. Em um aspecto formal, no entanto, a restrição poderá ocorrer de modos variados, seja por meio de regras (a solução do conflito entre princípios se manifesta na regra infraconstitucional), seja por meio de decisões judiciais em cada caso concreto, baseada em critérios de proporcionalidade e razoabilidade.

\subsubsection{Da proporcionalidade e da razoabilidade}

Conforme analisado no item anterior, adotando-se a teoria externa, é assumida a concepção de direitos fundamentais como princípios e o consequente entendimento de que suas restrições são reflexo da colisão entre o âmbito de atuação dos princípios, especialmente diante do suporte fático amplo preconizado pelos mesmos.

Deste modo, faz-se necessária a verificação de meios para sopesamento e a criação de condutas que qualifiquem e promovam as limitações aos direitos fundamentais. Os critérios mais utilizados para controle das restrições resultantes do choque entre princípios são a proporcionalidade e a razoabilidade. Em verdade, trata-se, pois, de limite dos limites (em verdade, restrição das restrições, já que não se trata de limites, mas de restrições) a direitos fundamentais e a bens constitucionalmente protegidos. ${ }^{86}$

Inicialmente à análise da questão dos critérios de apuração das condutas utilizadas para promover restrições aos direitos fundamentais, necessário se faz um esclarecimento acerca das expressões usadas nas referências dos cânones em exame.

\footnotetext{
86 STEINMETZ, Wilson. Princípio da Proporcionalidade e Atos de Autonomia Privada. Interpretação Constitucional. Org. Virgílio Afonso da Silva. 1a ed. $2^{\mathrm{a}}$ tiragem. São Paulo: Editora Malheiros, 2007. p. 13.
} 
O termo razoabilidade é utilizado pelo direito norte-americano, a fim de qualificar tudo o que seja conforme a razão. ${ }^{87}$ Tem sua origem e desenvolvimento fundamentados na garantia do devido processo legal (due process of law), instituto advindo do Direito anglosaxão. ${ }^{88}$ E tal instituto enseja a necessidade de análise da adequação do meio empregado pelo legislador e os fins objetivados, além da própria legitimidade de tais fins. Apenas se presentes tais condições, um direito individual poderá ser limitado. ${ }^{89}$

A interpretação do termo razoabilidade traduz uma ideia de "adequação, idoneidade, aceitabilidade, logicidade, equidade" 90 , uma ideia daquilo que não é absurdo, mas, ao contrário, é admissível, sensato, prudente e moderado.

Por outro lado, o termo proporcionalidade apresenta um sentido mais limitado, representando um equilíbrio, uma ideia de harmonização entre duas grandezas. Porém, é também admitida uma interpretação ampla a esse termo, envolvendo a adequação e a utilidade entre os meios e os fins na consecução de um ato para a proteção de um determinado direito. 91

A própria análise da questão da proporcionalidade ainda esbarra no debate acerca de sua correta nomenclatura. Entende Virgílio Afonso da Silva como incorreta a utilização da expressão "princípio da proporcionalidade”, na medida em que a análise da proporcionalidade apresenta uma estrutura de regra, porquanto impõe um dever definitivo, não estando sujeita a condicionantes fáticas e jurídicas do caso concreto ${ }^{92}$. Em sua concepção, a expressão mais correta e adequada seria, portanto, "regra da proporcionalidade", afastada da noção de regra

\footnotetext{
${ }^{87}$ BARROS, Suzana de Toledo. O Principio da Proporcionalidade e o Controle de Constitucionalidade das Leis Restritivas de Direitos Fundamentais. Brasília, DF: Livraria e Editora Brasília Jurídica, 1996. p. 67.

${ }^{88}$ BARROSO, Luis Roberto. Os Princípios da Razoabilidade e da Proporcionalidade no Direito Constitucional. Cadernos de Direito Constitucional e Ciência Política. Instituto Brasileiro de Direito Constitucional. ano 6. $\mathrm{n}^{\circ}$ 23. abril-junho de 1998. p. 65.

${ }^{89}$ BARROSO, op. cit., p. 66-67.

${ }^{90}$ BARROS, op. cit., p. 68.

91 "Há quem diga que a própria razoabilidade das leis, para os americanos, também significaria mais que um juízo de necessidade, adequação e justa medida das restrições impostas. Ela contempla um juízo de adequação dos valores eleitos pelo legislador como fator de restrição ou discrímen e aqueles aceitos pela sociedade americana. por isso dizerem alguns autores que a proporcionalidade, mesmo em sentido amplo, seria um aspecto da razoabilidade". (Ibid., p. 67).

${ }^{92}$ Essa questão terminológica é analisada detalhadamente por Virgílio Afonso da Silva no estudo O proporcional e o razoável. RT 798. ano 91. São Paulo: Editora Revista dos Tribunais, 2002.
} 
de conduta ou regra de atribuição de competências, mas considerada uma regra especial ou meta-regra. ${ }^{93}$

Em outro entendimento, Robert Alexy, ao referir-se à proporcionalidade como critério de solução de conflitos entre direitos fundamentais, menciona a expressão "máxima da proporcionalidade" ${ }^{94}$, conforme comumente adotada na doutrina alemã. Tal expressão, interpretada na linguagem jurídica brasileira, no entanto, pode ser refutada por traduzir uma impressão de mera recomendação. ${ }^{95}$

Ainda no debate acerca da terminologia a ser utilizada ao se analisar a questão da proporcionalidade, Humberto Ávila ${ }^{96}$ sugere a expressão “postulado normativo aplicativo”, por estabelecer a estrutura de aplicação de outras normas. Todavia, assim como defende Virgílio Afonso da Silva, o postulado normativo aplicativo da proporcionalidade também possui estrutura de regra, de modo que, no presente estudo, utilizaremos a expressão "regra de proporcionalidade".

Superada a questão da terminologia, e partindo-se da concepção de que a regra da proporcionalidade condiciona a aplicação de outras regras, faz-se necessário analisar os elementos que a configuram, ou seja, os elementos que lhe dão "a densidade indispensável para alcançar a funcionalidade pretendida pelos operadores de direito". 97

A doutrina alemã estabelece uma estrutura ${ }^{98}$ na qual a regra da proporcionalidade é formada por três elementos indispensáveis e indissociáveis, de forma a verificar se medida a intervir no âmbito de proteção de um direito fundamental é legítima: a adequação (Geeignetheit), a necessidade (Enforderlichkeit) e a proporcionalidade em sentido estrito (Verhältnismässigkeit).

\footnotetext{
${ }^{93}$ SILVA, op.cit., p. 168-169.

${ }^{94}$ ALEXY, op.cit., p. 116-118.

${ }^{95}$ SILVA, op. cit., p. 168.

96 ÁVILA, Humberto apud SILVA, op. cit., p. 168-169.

${ }^{97}$ BARROS, op. cit., p. 68.

${ }^{98}$ Tal estrutura é seguida por vários doutrinadores brasileiros, dentre eles Virgílio Afonso da Silva, Suzana de Toledo Barros, Luis Roberto Barroso.
} 
O primeiro elemento a ser aplicado pela regra de proporcionalidade é a adequação. O meio aplicado (pelo legislador ou pelo controle judicial) deve ser adequado e exigível para que o fim almejado seja alcançado.

A adequação pode ser traduzida na análise da idoneidade da medida restritiva à consecução da finalidade objetivada, sob pena de ser considerada inconstitucional. Em suma: deve-se avaliar a razão da intervenção em um direito fundamental, resultando em sua limitação: "a medida adotada é adequada para fomentar a realização do objetivo perseguido?",99

Importa ressaltar que a análise da adequação não considera a eventual realização completa do fim objetivado, mesmo porque é impossível saber, por antecipação, se a medida realizará, por completo, o fim a que se propõe.

O segundo elemento qualificador da regra da proporcionalidade é a necessidade (ou exigibilidade) da medida, também conhecido como "princípio da menor ingerência possível". 100

O exame do elemento necessidade consiste na avaliação do meio utilizado para o fim desejado, de forma a ser o menos gravoso possível dentro das opções existentes. É, em verdade, um teste comparativo, visando à proibição do excesso.

Enquanto a análise da adequação segue um critério absoluto, na medida em que apenas compatibiliza a relação entre um meio e um fim, o exame da necessidade considera a verificação da indispensabilidade da medida restritiva e a impossibilidade de substituição da mesma por outra igualmente eficaz, mas menos gravosa. Ou seja: "o meio mais idôneo e a menor restrição possível". ${ }^{101}$

Para considerar uma medida exigível e necessária, para fins de proporcionalidade, é importante que (i) se verifique a inexistência de outra medida menos gravosa e que, portanto,

\footnotetext{
${ }^{99}$ SILVA, op. cit., p. 170.

${ }^{100}$ BARROSO, op. cit., p. 72.

${ }^{101}$ LERCHE apud BARROS, op.cit., p. 76.
} 
reflita menor restrição e, (ii) ao mesmo tempo, esteja apta a, no mínimo, fomentar a realização do objetivo perseguido.

Diante disso, é forçoso concluir que o elemento adequação antecede a análise da necessidade. Só é possível analisar a necessidade (ou exigibilidade) de uma medida restritiva se o meio empregado for idôneo e adequado.

Muito embora seja possível se admitir que, em certas hipóteses, os elementos da adequação e da necessidade possam, por si sós, ser suficientes para justificar a adoção de uma medida restritiva de direitos fundamentais, a verdade é que muitas vezes tais requisitos não são passíveis de determinar a justiça da medida adotada, podendo resultar em um desequilíbrio da relação meio-fim.

Deste modo, faz-se necessária a utilização de um critério apto a identificar se o meio utilizado pela medida restritiva encontra-se em razoável proporção com o objetivo buscado, promovendo um equilíbrio entre valores e bens. ${ }^{102}$

$\mathrm{O}$ terceiro requisito da regra de proporcionalidade é identificado como proporcionalidade em sentido estrito. Trata-se da "ponderação entre os danos causados e os resultados a serem obtidos. Em palavras de Canotilho, trata-se de "uma questão de 'medida' ou 'desmedida' para se alcançar um fim: pesar as desvantagens dos meios em relação às vantagens do fim"', 103

Em resumo: a função do exame da proporcionalidade em sentido estrito é justamente evitar o exagero, evitar que medidas restritivas, ainda que adequadas e necessárias, "restrinjam direitos fundamentais além daquilo que a realização do objetivo perseguido seja capaz de justificar". ${ }^{104}$ Vai, portanto, além da simples adequação e da premente necessidade: é uma análise da melhor forma que a restrição pode se apresentar, a fim de que não se torne excessiva.

\footnotetext{
${ }^{102}$ BARROS, op. cit., p. 80.

${ }^{103}$ BARROSO, op. cit., p. 72

${ }^{104}$ SILVA, op. cit., p. 175.
} 
Aliás, a basilar diferença entre o requisito da necessidade e o da proporcionalidade strictu sensu reside justamente no fato de que a necessidade analisa a otimização com relação a possibilidades fáticas, enquanto que a proporcionalidade em sentido estrito envolve a otimização de possibilidades jurídicas. ${ }^{105}$

Por depender e estar intimamente conectada aos demais requisitos da regra de proporcionalidade (adequação e necessidade), a proporcionalidade em sentido estrito jamais poderá ser analisada em um primeiro momento e apartada dos outros elementos.

\begin{abstract}
A proporcionalidade em sentido estrito, como visto, é um princípio que pauta a atividade do legislador segundo a exigência de uma equânime distribuição de ônus. Todavia, por si, não indica a justa medida do caso concreto. Esta há de ser inferida a partir da técnica de ponderação de bens, na qual o juízo de valoração de quem edita ou controla a medida restritiva de direito é bastante amplo, dando margem à tese, defendida por muitos, de que se trata de tarefa impossível de ser efetuada, pela dificuldade de separar, medir e comprovar valores e interesses em conflito. ${ }^{106}$
\end{abstract}

A regra da proporcionalidade é, pois, um método de ponderação de bens e interesses, resultado da colisão de princípios face a um suporte fático amplo dos direitos fundamentais. É a partir da análise dessa regra que se pode apurar a eventual limitação (ou restrição) de direitos refletivos do princípio da dignidade humana em casos concretos.

A questão que se enfrenta ao permitir restrições aos direitos fundamentais (em razão de conflitos entre princípios, esclareça-se) é a possibilidade de se atingir o conteúdo essencial de um direito fundamental a partir de uma análise de proporcionalidade.

Tal questionamento será enfrentado no item a seguir.

\title{
1.5.2 Do conteúdo (núcleo) essencial dos direitos fundamentais
}

A Constituição Alemã, em seu artigo $19, \S 2^{\circ}$, traz a proibição da afetação dos direitos fundamentais em seu conteúdo essencial ${ }^{107}$. Muito embora não estabeleça a definição do que

\footnotetext{
${ }^{105}$ BARROS, op. cit., p. 81.

${ }^{106}$ BARROS, op. cit., p. 82-83.

${ }^{107}$ ALEXY, op. cit., p. 296.
} 
seja conteúdo essencial, tal preceito traduz uma forma de limitar a própria restrição a direitos fundamentais.

A ideia do núcleo essencial surge como último limite de garantia contra leis e medidas excessivamente restritivas aos direitos fundamentais. Ou seja, trata-se de uma tentativa de delimitar o mínimo de direito fundamental necessário para a manutenção do princípio maior da dignidade humana ${ }^{108}$.

Dentro da concepção de conteúdo essencial, sua definição pode ser vislumbrada a partir de dois enfoques: o objetivo e o subjetivo. ${ }^{109}$ Em uma concepção objetiva, o núcleo essencial de um direito fundamental deve ser definido conforme sua importância para a vida de toda a sociedade, de forma a proibir limitações à eficácia desse direito. Já por uma concepção subjetiva, a função do conteúdo essencial é de defesa, visando tão somente proteger o direito fundamental dentro de uma perspectiva individual.

Diante da proteção buscada pela ingerência de um núcleo essencial, ambos os enfoques devem estar interligados, de forma a garantir não só a defesa dos direitos fundamentais em uma perspectiva global, mas também dentro de um contexto individual, a partir de posições jurídicas e condutas individuais. ${ }^{110}$

No que concerne à abrangência do conteúdo essencial dos direitos fundamentais, a doutrina alemã apresenta duas teorias. A teoria do conteúdo essencial absoluto defende que este é instransponível, independentemente dos interesses envolvidos, não podendo sofrer qualquer tipo de relativização, ainda que decorrentes de urgências ou contingências. ${ }^{111}$

Já a teoria do conteúdo essencial relativo, ao contrário da anterior, estabelece a possibilidade de variação do núcleo dos direitos fundamentais, afastando a incidência de um contorno fixo e previamente definido, sendo dependente das "condições fáticas e das colisões

\footnotetext{
108 "Não é à toa que juristas do porte de Ernst Benda chegaram a afirmar que os direitos e garantias fundamentais constituem garantias específicas da dignidade da pessoa humana, da qual são - em certo sentido - mero desdobramento". (SARLET, Ingo Wolfgang. Dignidade da Pessoa Humana e Direitos Fundamentais na Constituição de 1988. Porto Alegre: Livraria do Advogado, 2001. p. 103).

${ }^{109}$ SILVA, op. cit., p. 185.

${ }^{110}$ Ibid., p. 186.

${ }^{111}$ Ibid., p. $187-188$.
} 
entre diversos direitos e interesses no caso concreto."112 Deste modo, segundo a teoria relativa, "o conteúdo essencial é aquilo que resta após o sopesamento", ${ }^{113}$ ou seja, é um conceito-limite surgido após a aplicação da regra da proporcionalidade.

Para essa teoria, portanto, a existência de um suporte fático amplo dos direitos sociais e a utilização da regra da proporcionalidade como forma de controle da aplicação dos princípios, torna inviável a defesa de um conteúdo essencial absolutamente imutável, na medida em que as restrições que passam pelo controle de proporcionalidade (restrição proporcional) não tem o condão de atingir o núcleo essencial de um direito fundamental, já que não o extirpam do ordenamento jurídico ${ }^{114}$.

O principal desafio da teoria do núcleo essencial dos direitos fundamentais, independente de sua escolha - se absoluta ou relativa, é, em verdade, precisar um limite para a atividade do legislador, estabelecendo um conteúdo mínimo inviolável da norma constitucional, sem o qual o direito fundamental poderia ser eliminado. A função desse conteúdo essencial é, portanto, estabelecer uma linha fronteiriça, coibindo excessos por parte do legislador infraconstitucional.

Essa definição de núcleo essencial como limite dos limites é bem precisa quando a questão relaciona-se aos casos de restrições às dimensões negativas dos direitos, liberdades e garantias públicas, no qual deve o Estado permanecer inerte, abstendo-se de qualquer medida que implique a extinção do direito fundamental pessoal. Mas, e quando se trata de direitos sociais? Como aplicar uma teoria de conteúdo essencial aos direitos fundamentais sociais, que demandam uma posição ativa do Estado?

Nesse caso, a abordagem deve ser diversa. Muito embora possa ser assumida a posição de que o conteúdo essencial dos direitos sociais destina-se à proteção de um mínimo existencial, deve-se ter em mente a necessidade de uma participação estatal ativa para que o direito fundamental social possa ser realizado.

\footnotetext{
${ }^{112}$ SILVA, op. cit., p. 196.

113 ALEXY, op. cit., p. 297.

114 “(...) não se deve confundir a necessidade de harmonizar, no caso concreto, a dignidade na sua condição de norma princípio (que, por definição, admite vários níveis de realização) com outros princípios e direitos fundamentais, de tal sorte que se poderá tolerar alguma relativização, com a necessidade de respeitar, proteger e promover a igual dignidade de todas as pessoas, não olvidando que, antes mesmo de ser norma jurídica, a dignidade é, acima de tudo, a qualidade intrínseca do ser humano e que o torna merecedor ou, pelo menos, titular de uma pretensão de respeito e proteção". (SARLET, op. cit., p. 139).
} 
O conteúdo essencial de um direito social, portanto, está intimamente ligado, a partir da teoria relativa, a um complexo de fundamentações necessárias para a justificação de eventuais não realizações desse direito. Em outras palavras: tanto quanto qualquer direito, um direito social também deve ser realizado na maior medida do possível, diante das condições fáticas e jurídicas presentes. O conteúdo essencial, portanto, é aquilo realizável nessas condições. Recursos a conceitos como o "mínimo existencial" ou a "reserva do possível" só fazem sentido diante desse arcabouço teórico. Ou seja, o mínimo existencial é aquilo que é possível realizar diante das condições fáticas e jurídicas, que, por sua vez, expressam a noção, utilizadas às vezes de forma extremamente vaga, de reserva do possível. ${ }^{115}$

Nesse sentido, verifica-se que para cada direito social é imprescindível não só a delimitação da garantia de existência do direito propriamente dito, mas também das prestações que devem ser realizadas a fim de garantir o direito fundamental estabelecido, estando ambos embutidos no conceito de conteúdo essencial. ${ }^{116}$

Nada obstante a ideia de núcleo essencial dos direitos fundamentais vigorar entre as principais categorias da "dogmática jurídico-constitucional do último meio século", ${ }^{117} \mathrm{o}$ ordenamento jurídico brasileiro não adotou, em sua Lei Maior, expressa previsão nesse sentido. Aliás, a Constituição Brasileira de 1988 sequer previu a regra da proporcionalidade, deixando a cargo dos Tribunais ${ }^{118}$ a utilização dessa sistemática com base no princípio do devido processo legal, em uma acepção de limite ao Legislativo ${ }^{119}$.

\footnotetext{
${ }_{115}^{11}$ SILVA, op. cit., p. 187-188.

116 "Em recente trabalho, tentam-se fornecer algumas pistas inovadoras a este respeito. Os pontos de partida para a compreensão do chamado Lep (Livelliessenzialidelleprestazioni), consagrado no art. 117 $/ 2$ da Constituição italiana (revista), parecem formulados em linguajar clássico: (i) o nível essencial de uma prestação referente a um direito social consubstancia um autêntico direito individual irrestringível fundado nas normas constitucionais; (ii) a constitucionalização de um direito essencial de prestação constitui uma heterodeterminação constitucional à autonomia normativa e administrativa de todos os níveis de governo, começando no governo central e acabando nos governos regionais e locais; e (iii) o nível essencial de prestação condiciona as políticas econômicas e financeiras". (CANOTILHO, José Joaquim Gomes. O Direito Constitucional como ciência de direç̧ão - o núcleo essencial de prestações sociais ou a localização incerta da socialidade (contributo para a reabilitação da força normativa da "Constituição Social". Direitos Fundamentais Sociais. Org. José Joaquim Gomes Canotilho, Marcus Orione Gonçalves Correia e Érica Paula Barcha Correia. São Paulo: Saraiva, 2010. p. 27).

${ }^{117}$ Ibid., p. 26.

118 “(...) a superação dos antagonismos existentes entre princípios constitucionais há de resultar da utilização, pelo STF, de critérios que lhe permitam ponderar e avaliar, hic et nunc, em função de determinado contexto e sob uma perspectiva axiológica concreta, qual deva ser o direito a ponderar no caso, considerada a situação de conflito ocorrente, desde que, no entanto, a utilização do método da ponderação de bens e interesses não importe em esvaziamento do conteúdo essencial dos direitos fundamentais, tal como adverte o magistério da doutrina." (Ministro Celso de Mello, RTJ 188, 858 (912) apud SILVA, Virgílio Afonso da.op. cit. p. 198-199).

${ }^{119}$ FELICIANO, Guilherme Guimarães. Direito à Prova e Dignidade Humana: cooperação e proporcionalidade em provas condicionadas à disposição física da pessoa humana (abordagem comparativa). São Paulo: LTr, 2007. p. 73.
} 
Por se tratar a Constituição Brasileira de carta com cunho eminentemente protecionista e compromissário, é possível (e imperativo) adaptar a acepção do conteúdo essencial dos direitos fundamentais prevista na Constituição Alemã ao direito brasileiro, de forma não só a garantir uma efetiva proteção dos direitos fundamentais (individuais ou sociais) face a eventuais ofensas e excessos, mas também a estabelecer condutas positivas tendentes a trazer eficácia aos direitos lá delimitados.

Essa noção configura-se determinante para a apuração do aspecto nuclear do direito fundamental a ser protegido em razão da proibição do retrocesso social a partir de uma constituição dirigente, tema que será revisitado no próximo capítulo.

\subsection{A influência da noção de direitos humanos no ordenamento jurídico brasileiro: a Constituição de 1988}

A Constituição Federal de 1988 foi a primeira constituição brasileira a elencar a prevalência dos direitos humanos, como princípio fundamental a reger o Estado brasileiro. É, portanto, a primeira constituição brasileira a consagrar um universo de princípios a reger o Brasil no que concerne à questão dos direitos humanos, introduzindo um "avanço extraordinário na consolidação dos direitos e garantias fundamentais". ${ }^{120}$ Vale ressaltar a importância dessa Constituição, por se tratar de um marco jurídico no retorno ao regime democrático, após mais de vinte anos de ditadura política.

Desde o seu preâmbulo, portanto, observa-se a consolidação de um Estado Democrático de Direito, no qual é assegurado

o exercício dos direitos sociais e individuais, a liberdade, a segurança, o bem-estar, o desenvolvimento, a igualdade e a justiça, como valores supremos de uma sociedade fraterna, pluralista e sem preconceitos, fundada na harmonia social e comprometida, na ordem interna e internacional, com a solução das controvérsias. ${ }^{121}$

\footnotetext{
${ }^{120}$ PIOVESAN, Flávia. Justiciabilidade dos direitos sociais e econômicos: desafios e perspectivas. Direitos Fundamentais Sociais. Org. José Joaquim Gomes Canotilho, Marcus Orione Gonçalves Correia e Érica Paula Barcha Correia. São Paulo: Saraiva, 2010. p. 54.

${ }^{121}$ Preâmbulo da Constituição da República Federativa do Brasil, promulgada em 05 de outubro de 1988.
} 
Ademais, além da construção de um Estado Democrático, a atual Lei Maior também promove a consolidação das garantias e direitos fundamentais, destacando-se a cidadania e a dignidade da pessoa humana.

A partir dela, os direitos humanos ganham relevo extraordinário, situando-se a Carta de 1988 como o documento mais abrangente e pormenorizado sobre os direitos humanos jamais adotado no Brasil. ${ }^{122}$

Diante dessa premissa, pode-se defender que a Carta Magna de 1988 elegeu a dignidade da pessoa humana como valor essencial que lhe dá unidade e sentido. Conferindo à dignidade da pessoa humana uma condição especial de ser o fundamento de todo o ordenamento jurídico brasileiro, a Carta de 1988 estabeleceu o entendimento de que todas as normas, inclusive as constitucionais, devem apresentar-se em consonância com esse princípio fundamental $^{123}$.

E mais. $\mathrm{Na}$ esteira do que ocorreu em outros países, como a Alemanha, não apenas estabeleceu sentido, justificação e finalidade para o exercício do poder estatal, mas também reconheceu, expressa e categoricamente, que o Estado existe em função da pessoa humana, constituindo o ser humano finalidade precípua da atividade estatal. ${ }^{124}$

$\mathrm{Na}$ busca pela dignidade da pessoa humana, apresentada como fundamento da República Federativa do Brasil (art. 3º III), a Constituição de 1988 assume, cristalinamente, o compromisso com a concepção contemporânea dos direitos humanos, institucionalizando-os e tratando de forma universal, indivisível e igualitária tanto os direitos individuais como os direitos sociais.

Essa é mais uma inovação trazida pela Magna Carta de 1988: a integração dos direitos sociais como direitos fundamentais de aplicabilidade imediata, já que anteriormente tais

\footnotetext{
${ }^{122}$ PIOVESAN, Flávia. Direitos Humanos e o Direito Constitucional Internacional. 3. ed. atual. São Paulo: Editora Max Limonad, 1997. p. 55.

123 "Importa considerar, neste contexto, que, na qualidade de princípio fundamental, a dignidade da pessoa humana constitui valor-guia não apenas dos direitos fundamentais, mas de toda a ordem jurídica (constitucional e infraconstitucional) - razão pela qual para muitos se justifica plenamente sua caracterização como princípio constitucional de maior hierarquia axiológico-valorativa (höchsteswertsetzendesVerfassungsprinzip)". (SARLET, Ingo Wolfgang. Algumas notas em torno da relação entre o princípio da dignidade da pessoa humana e os direitos fundamentais na ordem constitucional brasileira. Dos Princípios Constitucionais. Considerações em Torno das Normas Principiológicas da Constituição. Org. George Salomão Leite. São Paulo: Malheiros, 2003. p. 218).

${ }^{124}$ SARLET, op. cit., p. 215.
} 
direitos eram tratados de forma pulverizada e aleatória, dispersos pelo texto constitucional, não constando de um título dedicado aos direitos e garantias.

Importante salientar que, a exemplo do ocorrido com a Constituição Americana, a Constituição Brasileira de 1988 consagrou a ideia da abertura material do catálogo constitucional dos direitos e garantias fundamentais, assegurando direitos fundamentais em várias partes do texto constitucional, além de acolher direitos positivados em tratados internacionais e assumir a existência de direitos não escritos e implícitos (como o princípio da proibição do retrocesso social, objeto deste estudo), decorrentes dos princípios trazidos pela nova esfera constitucional. ${ }^{125}$

A alteração na ordem constitucional em razão do advento da Constituição de 1988 ainda promoveu o alargamento das obrigações do Estado, limitando os domínios da política, anteriormente livres e desvinculados, e gerando imposições, através de uma vinculação material normativa da própria atividade política. ${ }^{126}$

Ao serem incorporados ao ordenamento jurídico, por meio do texto constitucional, que é a expressão máxima da sistemática jurídica de um país, os direitos humanos apresentados como fundamentais passam a refletir um direito subjetivo, objeto de tutela protetiva e de participação ativa do Estado em sua concretização. Deste modo, tais direitos considerados fundamentais são retirados da esfera de disponibilidade dos poderes constituídos. De fato, a Lei Maior de 1988 conferiu a eles a condição de cláusula a, que se refere ao núcleo imutável e intocável da Constituição (art. $60, \S 4^{\circ}$, IV).

Ressalte-se que a existência de cláusula pétrea não se confunde com a aplicação de um conteúdo essencial aos direitos fundamentais, nos moldes vistos no item anterior. Isso porque as cláusulas pétreas são voltadas a coibir qualquer medida que importe a abolição dos direitos por ela cobertos, não se prestando a protege-los em caso de readequação, modificação ou qualquer alteração de condição ou efeito dos mesmos. Sendo a Constituição essencialmente mutável, uma vez que reflete os ideais e anseios de uma sociedade organizada, a simples estagnação dos direitos não deve ser acolhida.

\footnotetext{
${ }^{125}$ SARLET, op. cit., p. 228.

${ }^{126}$ PIOVESAN, Flávia. Justiciabilidade dos direitos sociais e econômicos: desafios e perspectivas. Direitos Fundamentais Sociais. Org. José Joaquim Gomes Canotilho, Marcus Orione Gonçalves Correia e Érica Paula Barcha Correia. São Paulo: Saraiva, 2010. p. 56.
} 
E é nessa medida que se destina a acepção do núcleo essencial. Sua função é, para além de resguardar os direitos de eventual extinção, garantir a existência de uma última barreira a alterações e/ou readequações trazidas pelo sistema, de forma evitar que o direito fundamental seja atingido em sua essência e, principalmente, em sua eficácia.

Não obstante a condição de cláusula pétrea, a Constituição de 1988 ainda reforçou a imperatividade das normas de direitos humanos traduzidas em direitos e garantias fundamentais. Nos termos do artigo $5^{\circ}$, parágrafo $1^{\circ}$ do texto constitucional, as normas definidoras de direitos e garantias fundamentais têm aplicabilidade imediata, inclusive decorrentes de normas internacionais. Isso significa que, com a previsão de um regime jurídico específico destinado a esses direitos, fica o Poder Público incumbido de "conferir eficácia máxima e imediata a todo e qualquer preceito definidor de direito e garantia fundamental". ${ }^{127} \mathrm{Em}$ verdade, a intenção da aplicabilidade imediata estatuída é justamente promover uma força dirigente e vinculante aos direitos humanos fundamentais, de forma a torná-los indistintamente aplicados pelos Poderes Executivo, Legislativo e Judiciário.

Nas palavras de Canotilho:

aplicação direta não significa apenas que os direitos, liberdades e garantias se aplicam independentemente da intervenção legislativa. Significa também que eles valem directamente contra a lei, quando esta estabelece restrições em desconformidade com a Constituição. ${ }^{28}$

Nesse diapasão, o princípio da prevalência dos direitos humanos adotado pela Lei Maior deve nortear todas as legislações a serem produzidas, sob pena de inconstitucionalidade, além de desrespeito aos instrumentos internacionais de proteção aos direitos humanos ratificados pelo Brasil.

\footnotetext{
${ }^{127}$ PIOVESAN, Flávia. Direitos Humanos e o Direito Constitucional Internacional. 3. ed. atual. São Paulo: Editora Max Limonad, 1997. p. 64.

${ }^{128}$ CANOTILHO apud PIOVESAN, op. cit., p. 64.
} 


\section{DA PROTEÇÃO DOS DIREITOS HUMANOS: O PRINCÍPIO DA PROIBIÇÃO DO RETROCESSO SOCIAL}

\subsection{A Proteção dos Direitos Humanos}

Diante de tudo o que já foi anteriormente mencionado, denota-se a existência de um arquétipo constitucional no sentido de promover a proteção indistinta dos direitos humanos, de tal forma a traduzi-los como fundamentais.

Toda a estrutura jurídico-constitucional é organizada com o objetivo de observar tais direitos e, a partir daí, garantir sua aplicabilidade, inviabilizar sua eliminação e limitar eventual e necessária restrição.

Expressamente, a Constituição brasileira de 1988 estabeleceu duas formas de proteção aos direitos humanos: a primeira, por meio da própria previsão legal, elevando tais direitos à categoria de direitos fundamentais e destacando-os como necessários à promoção da dignidade humana. A segunda, com a criação das chamadas cláusulas pétreas, que impedem a mera proposta de emenda constitucional tendente a abolir os direitos fundamentais.

Um dos maiores problemas enfrentados na proteção dos direitos humanos, entretanto, é justamente estabelecer o ponto que separa o limite máximo de relativização da afetação da essência daquele direito considerado fundamental. E essa identificação é a chave para a manutenção do catálogo constitucional de direitos humanos fundamentais e sua aplicabilidade.

Uma solução para a questão da consignação da linha fronteiriça entre o ponto máximo de relativização do direito fundamental e a afetação de sua essência ou até mesmo sua total aniquilação, conforme já visto no capítulo anterior, é a acolhida da teoria do núcleo essencial intransponível dos direitos humanos fundamentais, à luz do que estabelece a constituição alemã.

Tal entendimento, especialmente quando se trata de direitos sociais, que demandam uma postura ativa do Estado para sua implementação, assume um papel relevante quando se 
descortinam formas implícitas de proteção aos direitos fundamentais, como é a questão da proibição do retrocesso social, que será analisada neste capítulo.

\subsubsection{Identificação do aspecto nuclear do direito a ser protegido}

A Constituição alemã prevê, em seu texto, a existência de um núcleo essencial dos direitos humanos fundamentais ${ }^{129}$. Por essa determinação, esse núcleo seria intangível, ou seja, não poderia ser objeto de revisão, alteração e, tampouco, extinção.

A Constituição Brasileira de 1988, nada obstante frisar a importância da proteção aos direitos fundamentais, não trouxe em seu bojo qualquer manifestação no sentido de estabelecer um núcleo limitador de eventuais restrições. Contudo, como já visitado no capítulo anterior, é imperioso admitir a aplicação da teoria do conteúdo essencial ao ordenamento jurídico brasileiro, face ao caráter protecionista com que se apresenta.

Para se desenvolver a questão da proteção aos direitos fundamentais (em especial direito fundamentais sociais, objeto específico desse estudo) à luz de uma questão de retrocesso social, é preciso analisar, ainda que de forma breve, de que forma a aplicação da teoria do núcleo essencial tem efetividade nesse propósito, a partir de uma identificação do que seja esse conteúdo intocável.

É necessário salientar, no entanto, que não é objetivo do presente estudo aprofundar às minúcias as questões que envolvem a análise da identificação do conteúdo essencial do direito fundamental. Isso porque tal verificação demandaria um estudo específico da matéria, o que foge do escopo do presente trabalho. Tentar-se-á, neste momento, tão somente demonstrar a necessidade de manutenção de uma parcela do conteúdo de um direito fundamental,

\footnotetext{
129 “Artigo 19 Restrição dos direitos fundamentais - Via judicial (1) Na medida em que, segundo esta Lei Fundamental, um direito fundamental possa ser restringido por lei ou em virtude de lei, essa lei tem de ser genérica e não limitada a um caso particular. Além disso, a lei terá de citar o direito fundamental em questão, indicando o artigo correspondente. (2) Em nenhum caso, um direito fundamental poderá ser violado em sua essência. (3) Os direitos fundamentais também são válidos para as pessoas jurídicas sediadas no país, conquanto, pela sua essência, sejam aplicáveis às mesmas. (4) Toda pessoa, cujos direitos forem violados pelo poder público, poderá recorrer à via judicial. Se não se justificar outra jurisdição, a via judicial será a dos tribunais ordinários. Mantém-se inalterado o artigo 10 §2, segunda frase.” (Constituição da República Federal da

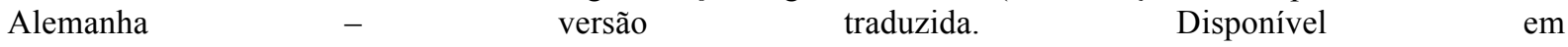
$<$ http://www.brasil.diplo.de/Vertretung/brasilien/pt/01 Willkommen/Constituicao Hino Bandeira/Constitui cao Seite.html>. Acesso em 20 de outubro de 2012.
} 
principalmente a partir de uma vinculação do legislador, sem a qual tal direito perde a sua mínima eficácia. ${ }^{130}$

Conforme já analisado anteriormente, a garantia do conteúdo essencial tem como escopo a restrição das restrições (ou limitação das limitações, conforme a teoria que se adote), ou seja, ser a última barreira impeditiva da ingerência do poder de revisão, sem a qual o direito fundamental estaria extinto.

Essa restrição, à luz da doutrina alemã, pode assumir duas diferentes faces, de acordo com a situação de regulação constitucional: objetiva e subjetiva. ${ }^{131}$ Longe de serem contrapostas, essas duas teorias se complementam. ${ }^{132133}$

A aplicação da teoria objetiva é premente, na medida em que a garantia do conteúdo essencial deve ser analisada como um todo, com efeitos para toda a sociedade. Em suma: a proteção ao núcleo essencial, sobre esse aspecto, visa coibir a restrição (ou a limitação) à eficácia de um direito fundamental, de modo a torná-lo sem aplicabilidade para todos os indivíduos de uma sociedade, ou pelo menos boa parte deles.

Portanto, diante da aplicação indistinta dos direitos fundamentais a todos os membros de uma sociedade, bem como de sua garantia para alcance da dignidade humana, não há como se afastar o entendimento de que sua proteção deve ter dimensão objetiva.

\footnotetext{
${ }^{130}$ SARLET, Ingo Wolfgang. A Eficácia dos Direitos Fundamentais: uma teoria geral dos direitos fundamentais na perspectiva constitucional. $10^{\mathrm{a}} \mathrm{ed}$. rev., atual. e ampl. Porto Alegre: Livraria do Advogado, 2009.

${ }^{131}$ ALEXY, op. cit., p. 296.

132 "O próprio Tribunal Federal Constitucional alemão, ao interpretar a Constituição, deixa em aberto a questão da análise a partir de uma teoria objetiva ou subjetiva do artigo $19, \S 2^{\circ}$, que trata do conteúdo essencial do direito fundamental, justamente por admitir que é desnecessário, para apurar a restrição a direito fundamental, se a mesma decorre de caso específico ou de uma afetação da garantia geral. Nada obstante, tal Tribunal mormente associa a garantia do conteúdo essencial a posições individuais, na medida em que é dessa forma que invariavelmente a questão se apresenta. "Se a Constituição estabelece algo tão importante quanto uma proibição de afetação do conteúdo essencial dos direitos fundamentais, então, isso diz respeito no mínimo também a posições de direitos fundamentais individuais". (Ibid., p. 296. (grifos no original)).

${ }^{133}$ Ao tratar do princípio da salvaguarda do núcleo essencial, menciona Canotilho que "a solução do problema não pode reconduzir-se a alternativas radicais porque a restrição dos direitos, liberdades e garantias deve ter em atenção a função dos direitos na vida comunitária, sendo irrealista uma teoria subjectiva desconhecedora dessa função, designadamente pelas consequências daí resultantes para a existência da própria comunidade, quotidianamente confrontada com a necessidade de limitação dos direitos fundamentais mesmo no seu núcleo essencial (ex.: penas de prisão longas para crimes graves, independentemente de se saber se depois do seu cumprimento restará algum tempo de liberdade ao criminoso). Todavia, a proteção do núcleo essencial não pode abdicar da dimensão subjectiva dos direitos fundamentais e daí a necessidade de evitar restrições conducentes à aniquilação de um direito subjectivo individual (ex.: proibição de prisão perpétua ou pena de morte, pois estas penas violariam o núcleo essencial do direito à liberdade ou do direito à vida)". (CANOTILHO, op. cit., p. 459)
} 
Por outro lado, mesmo com uma proteção trazida pela concepção objetiva, a restrição (ou a limitação) a um direito fundamental invariavelmente afetará o âmbito individual de um membro da sociedade, especialmente quando houver colisão de princípios decorrente de situação concreta. Nessa medida, vislumbra-se também a possibilidade de uma acepção subjetiva na regulação constitucional. Nesse sentido:

Se se pretende, com o recurso à garantia de um conteúdo essencial dos direitos fundamentais, proteger tais direitos contra uma restrição excessiva e se os direitos fundamentais, ao menos em sua função de defesa, têm como função proteger sobretudo condutas e posições jurídicas individuais, não faria sentido que a proteção se desse apenas no plano subjetivo. Isso porque é perfeitamente possível - e provável - que uma restrição, ou até mesmo uma eliminação, da proteção de um direito fundamental em caso concreto individual não afete sua dimensão objetiva, mas poderia significar uma violação ao conteúdo essencial daquele direito naquele caso concreto. ${ }^{134}$

Independentemente do aspecto que se analise o direito fundamental, se através de uma perspectiva de sociedade ou se através de uma perspectiva individual, fato é que a defesa e a concretização dos direitos fundamentais, e em especial, de seu núcleo essencial, devem ser feitas a partir de uma inserção sistemática da ordem constitucional. ${ }^{135}$

Dentro de uma análise sistêmica, e principalmente, em vistas de um estudo sobre a revisão e a aplicabilidade das normas constitucionais e o retrocesso social, a utilização de um entendimento objetivo é uma questão de coerência argumentativa.

A partir dessa constatação, o ponto principal para diagnosticar a importância do núcleo essencial para a proteção dos direitos fundamentais é identificar o próprio núcleo sobre o qual não se pode atingir.

A Constituição alemã, nada obstante mencionar a existência de um núcleo inatingível, não faz qualquer menção sobre qual seria esse núcleo, de modo que sua verificação depende de outro par de conceitos: núcleo essencial absoluto ou núcleo essencial relativo.

\footnotetext{
${ }^{134}$ SILVA, op. cit., p. 186.

${ }^{135}$ NETTO, Luísa Cristina Pinto e. O Princípio da Proteção do Retrocesso Social. Porto Alegre: Livraria do Advogado, 2010. p. 178.
} 
Absoluto é o núcleo essencial que não sofre qualquer tipo de relativização a partir de contingências concretas. Vale ressaltar que não necessariamente será imutável, apenas não comportará variações interpretativas de cada circunstância. Assim, mesmo não sofrendo relativização, poderá o conteúdo essencial assumir uma postura dinâmica, desenvolvendo-se de forma a se tornar apto a reagir às mudanças da realidade. Ou seja, "a estaticidade deste conteúdo essencial não impede a dinamicidade do conteúdo total."136

\begin{abstract}
Dinâmico e absoluto é o conteúdo essencial de um direito fundamental quando, embora constitua uma área intransponível em qualquer situação, seu conteúdo pode ser modificado com a passagem do tempo. A característica "absoluta" do conteúdo essencial não significa nem exige, portanto, imutabilidade. Absoluto, nesse contexto, implica apenas que aquilo é protegido pelo conteúdo essencial não sofre relativizações de acordo com urgências e contingências. ${ }^{137}$
\end{abstract}

No núcleo essencial relativo não há predefinição de conteúdo. O ponto essencial advirá com análise das condições fáticas e das colisões entre diversos direitos e interesses em cada caso concreto. Assim, o núcleo essencial de um direito jamais será sempre o mesmo, podendo variar em cada circunstância apresentada, a partir da aplicação da regra da proporcionalidade.

Adotando-se a teoria relativa, tem-se que o núcleo essencial de um direito é variável conforme um sopesamento de princípios. Ou seja, em um determinado caso concreto, havendo colisão entre o âmbito de proteção de dois direitos fundamentais, um deverá ser sacrificado em detrimento do outro. Porém, se tal sacrifício for realizado dentro das perspectivas do razoável, adequado, necessário e proporcional, não haverá ofensa ao núcleo essencial do direito, de modo que tal restrição será considerada constitucional.

A questão que se coloca é que a verificação do âmbito inicial de proteção de um direito não se resolve por meio de ponderação. Ainda, as posições prima facie adscritas à disposição de direito fundamental também não se fazem por ponderação. E, principalmente, a verificação das normas e posições essenciais para a identificação do direito fundamental também não se faz por meio de ponderação com outras normas. ${ }^{138}$ Inaplicável, pois, a teoria relativa.

\footnotetext{
${ }^{136}$ SILVA, op. cit., p. 190. (grifos no original).

${ }^{137}$ Ibid., p. 188.

${ }^{138}$ NETTO, op. cit., p. 179.
} 
Em posição contrária à defendida por grandes doutrinadores ${ }^{139}$, pode-se estabelecer que a determinação do núcleo essencial de um direito fundamental não é determinada pela

ponderação com outros direitos ou bens dignos de tutela, mas pela análise da importância - vínculo material - das normas e posições para a identificação deste direito, conferindo-lhe significado normativo como elemento da ordem jurídica. $^{140}$

Isso ocorre porque o que se determina como conteúdo essencial não são as normas e posições definitivas - essas, sim, definidas por meio da regra da proporcionalidade solucionadora de conflitos em casos concretos -, mas as normas e posições indispensáveis para sua caracterização.

A aceitação de uma teoria absoluta, contudo, não significa que o conteúdo essencial de um direito fundamental seja absolutamente imutável. Sua determinação, conforme já mencionado, comporta uma posição dinâmica, dependente de um contexto espacial, temporal e cultural.

O sopesamento entre princípios não pode ser, deste modo, caracterizado como elemento definidor do núcleo essencial, na medida em que não delimita nem identifica o âmbito de proteção inicial do direito (normas e posições prima facie), mas apenas baliza as eventuais intervenções no âmbito de proteção dos direitos, para além do núcleo essencial, averiguando inconstitucionalidades a partir de critérios de adequação, necessidade e proporcionalidade. É nessa medida que se aplicam as "relações condicionadas de precedência"141, resultantes da utilização da ponderação entre princípios garantidores de direitos fundamentais. ${ }^{142}$

\footnotetext{
139 “A extensão da proteção "absoluta" depende de relação entre princípios."(ALEXY, op. cit., p. 301). "A simples aceitação da proporcionalidade já traz consigo a garantia de um conteúdo essencial para esses direitos" (SILVA, op. cit., p. 203).

${ }^{140}$ Ibid., p. 181.

141 SILVA, op. cit., p. 50.

142 "Ainda no que diz com a legitimidade de eventuais medidas restritivas, há que considerar que a aferição da proporcionalidade da restrição poderá ser realizada apenas à luz do caso concreto, já que a resposta depende da comparação entre o interesse público na restrição e o interesse individual do titular do direito na sua preservação, não podendo, portanto, ser pré-estabelecida de forma genérica e abstrata." (SARLET, Ingo Wolfgang. O Estado Social de Direito, a Proibição de Retrocesso e a Garantia Fundamental da Propriedade. Revista Eletrônica sobre a Reforma do Estado (RERE). n 9. Salvador: Instituto Brasileiro de Direito Público, março/abril/maio, 2007. Disponível em $<$ http://www.direitodoestado.com.br/rere.asp $>$. Acesso em 20 de março de 2011).
} 
O conteúdo essencial, ao contrário, é umbilicalmente ligado à identificação do direito em seu componente abstrato, integrando as faculdades e possibilidades de atuação de forma preexistente ao próprio momento legislativo. ${ }^{143}$ Sua interpretação deve ser feita de forma autônoma, "estando a salvo de disposições legislativas independentemente de quaisquer ponderações concretas de direitos e interesses." 144

A resistência do núcleo essencial dos direitos fundamentais traduz-se, na realidade, em um reforço de proteção, em uma nova barreira que impede sua inviabilização e sua extirpação. Nessa medida, a resistência do conteúdo essencial às leis infraconstitucionais ocorre não porque são invioláveis ou intocáveis por si sós ou por entendimento da própria lei, mas porque sua intangibilidade decorre de um "direito superior constitutivo de nossa identidade jurídico-cultural" ${ }^{\prime 145}$.

Quem propõe, em sede de revisão constitucional, a supressão de um preceito formulador de um direito terá de demonstrar que a eliminação do texto escrito deixa imperturbados os princípios ou o núcleo essencial do bem protegido, esses sim materialmente irrevisíveis. ${ }^{146}$

Deste modo, observa-se que, ao se considerar a aplicabilidade e a regulamentação de normas constitucionais e o conteúdo essencial dos direitos fundamentais, pode-se assumir o entendimento de que o princípio material do núcleo apresenta contornos mais estreitos, tornando a garantia do direito fundamental insuscetível de interpretação casuística que leve à sua perturbação ou à sua extinção.

Partindo dessa premissa, surge a principal questão acerca do núcleo essencial dos direitos fundamentais: a identificação pontual do que é considerado vital em cada direito fundamental. $^{147}$

\footnotetext{
${ }^{143}$ GEBRAN NETO, João Pedro. A Aplicação Imediata dos Direitos e Garantias Individuais: a busca de uma exegese emancipatória. São Paulo: Editora Revista dos Tribunais, 2002. p. 53.

${ }^{144}$ FELICIANO, Guilherme Guimarães. Tutela Processual de Direitos Humanos Fundamentais: inflexões no "due processo of law". Tese. Lisboa: Faculdade de Direito da Universidade de Lisboa, 2012 (prelo).

${ }^{145}$ CANOTILHO, José Joaquim Gomes. Estudo sobre Direitos Fundamentais. Coimbra: Coimbra Editora, 2004.

${ }^{146}$ CANOTILHO, op. cit., p. 143.

${ }^{147} \mathrm{Na}$ Espanha, o julgado STC 11/1981 serviu de leading case ao estabelecer que o núcleo essencial de um direito fundamental deve ser constituído (i) pelas possibilidades de atuação necessárias para que o direito possa ser reconhecido e inserido na própria descrição do tipo e (ii) pela identificação do interesse juridicamente protegido. (GEBRAN NETO, op. cit., p. 52-53):

"1. Los Jueces Ordinarios pueden no aplicar aquellas normas anteriores a la Constitución que consideren derogadas por ésta y pueden también plantear la cuestión de inconstitucionalidad ante el Tribunal Constitucional. 2. En el recurso de inconstitucionalidad es larga de los recurrentes el aportar argumentación consistente, y el
} 
Não há, contudo, qualquer indicação dogmática do aspecto nuclear de um direito fundamental. Mesmo porque os direitos fundamentais previstos na Constituição têm caráter distintos, sejam individuais, sociais, difusos. Consequentemente têm aspectos vitais diferenciados, podendo até mesmo, dentro de sua essencialidade, exigir uma posição ativa

Tribunal Constitucional puede optar entre rechazar la acción en aquello en que se encuentre insuficientemente fundada o examinar el fondo del asunto si encuentra razones para ello. 3. El objeto del proceso Constitucional no es la norma, sino la Ley, y para decidir acerca de la legitimidad de ésta no es preciso enjuiciar los criterios de aplicación del Derecho. 4. La reserva de Ley no tiene carácter retroactivo. 5. Del hecho de que el legislador no derogue una normativa anterior no puede deducirse que la haya asumido como propia. 6 . La Constitución es un marco de coincidencias suficientemente amplio para que dentro de él quepan opciones política de muy diferente signo. 7. Corresponde al legislador ordinario regular con mayor o menor generosidad las condiciones de ejercicio de un derecho siempre que no pase más allá de los límites impuestos por las normas constitucionales, límites que existen siempre y que, en ocasiones, se establecen sólo de modo mediato o indirecto. 8. El contenido esencial del derecho subjetivo, al que se refiere el art. 53 de la C.E., puede determinarse a partir del tipo abstracto, conceptualmente previo al momento legislativo, que resulta de las ideas generalizadas o convicciones generalmente admitidas entre los juristas, los Jueces y, en general, los especialistas en Derecho, de modo que constituyen el contenido esencial de un derecho subjetivo aquellas facultades o posibilidades de actuación necesarias para que el derecho sea recognoscible como pertinente al tipo descrito. 9. El contenido esencial puede determinarse también complementariamente a partir de lo que se llama los intereses jurídicamente protegidos, de modo que se rebasa o se desconoce el contenido esencial cuando el derecho queda sometido a limitaciones que lo hacen impracticables lo dificultan más allá de lo razonable o lo despojan de la necesaria protección. 10. El derecho de huelga es más que la simple libertad de huelga, ya que no consiste solamente en el levantamiento de las específicas prohibiciones, sino en el derecho de los trabajadores a colocar el contrato de trabajo en una fase de suspensión, y de este modo limitar la libertad del empresario, a quien se le veda contratar otros trabajadores y llevar a cabo arbitrariamente el cierre de la empresa. 11. El contenido esencial del derecho de huelga consiste en la cesación del trabajo en cualquiera de las manifestaciones o modalidades que puede revestir, lo que no excluye que el legislador, al regular las condiciones de ejercicio pueda considerar que algunas determinadas modalidades de cesación del trabajo pueden resultar abusivas siempre que los tipos o modalidades que admita sean bastante por sí solos para reconocer que el derecho existe como tal y eficaces para obtener las finalidades del derecho de huelga. 12. La titularidad del derecho de huelga pertenece a los trabajadores «uti singuli» pero las facultades en que consiste el ejercicio del derecho de huelga, en cuanto acción colectiva y concertada, corresponden tanto a los trabajadores como a sus representantes y a las organizaciones sindicales. 13. El derecho de huelga no ampara las perturbaciones en la producción de bienes y de servicios o en el normal funcionamiento de estos últimos introducidas con el fin de presionar sobre la Administración pública o sobre los órganos del Estado introducidas para conseguir que se adopten medidas gubernativas o que se introduzca una nueva normativa más favorable para los intereses de una categoría. 14. Los derechos constitucionales son irrenunciables. 15. El ejercicio del derecho de huelga puede quedar sometido por la Ley a procedimientos o a algún tipo de formalidades, porque el art. 53 de la C.E. permite que el legislador regule las condiciones de ejercicio de los derechos fundamentales. Es preciso, sin embargo, que el procedimiento y los formalismos no sean arbitrarios, que tengan por objeto proteger otros bienes e intereses constitucionalmente protegidos y que no sean tan rígidos o difíciles de cumplir que en la práctica hagan imposible el ejercicio del derecho. 16. Las huelgas de solidaridad están amparadas por el derecho de huelga. 17. No se puede equiparar la huelga, reconocida como derecho fundamental en el art. 28 de la C.E., con el cierre patronal, simple derecho cívico reconocido en el art. 37, que no puede ejercerse lícitamente cuando vacía de contenido el derecho constitucional de hacer huelga o se alza como barrera que lo impide. La Constitución Española no recoge el llamado principio de igualdad de armas. 18. Las limitaciones al derecho a la negociación colectiva que se consagra en el art. 37 de la C.E. sólo son lícitas si se encuentran justificadas ya que de otro modo afectarían al contenido constitucional definido en ese precepto. (Referencia número: 11/1981. Tipo: Sentencia. Fecha de Aprobación: 8/4/1981. Publicación BOE: 25/4/1981. Sala: Pleno: Excmos. Sres. GarcíaPelayo, Latorre, Díez de Velasco, Rubio, Begué, Díez-Picazo, Tomás, Gómez-Ferrer, Escudero, Fernández y Truyol. Ponente: don Luis Díez-Picazo y Ponce de León. Número registro: 192/1980 Recurso tipo: Recurso de inconstitucionalidad). Disponível em $<$ http://www.boe.es/buscar/doc.php?coleccion=tc\&id=SENTENCIA-1981$\underline{0011}>$. Acesso em 20 de março de 2012. (g.n.) 
para sua eficácia, sob pena de não serem devidamente garantidos, como é o caso dos direitos sociais.

Para os direitos sociais, culturais e econômicos em específico, haja vista dependerem de uma atuação do Estado no sentido de lhes garantir eficácia, a questão do conteúdo essencial ganha outro enfoque: a impossibilidade de se extinguir um direito de forma arbitrária e sem a devida substituição ou equivalência.

Para o mero fim de uma sistematização, pode-se considerar como núcleo essencial de um direito fundamental o mínimo necessário à consecução daquilo que se quer ver protegido, do objeto que define o direito humano fundamental, seja por meio de ações negativas ou ações positivas. Ademais, tal mínimo existencial também deve abranger um

padrão mínimo de segurança jurídica, que permita aos indivíduos confiar na manutenção das condições básicas de vida, o que se afigura como indispensável num Estado Democrático de Direito vocacionado para a promoção da justiça social. ${ }^{148}$

Qualquer tentativa de relativização de direitos considerados fundamentais, portanto, deverá respeitar o limite material do núcleo essencial de cada direito, ou seja, o mínimo existente para manter inalterada a integridade do bem que sustenta a acepção de fundamentalidade dos direitos e que está sendo por eles previsto e protegido: a dignidade humana.

E mais: as leis de regulamentação devem manter a garantia que conferem para a aplicabilidade do direito de cunho social, uma vez que a eliminação ou restrição dos mecanismos que garantam eficácia de um direito fundamental também têm o condão de afetar o núcleo essencial desse direito, na medida em que inviabiliza a sua total abrangência.

\subsection{Evolução histórica e definição do princípio da proibição do retrocesso social}

A questão da proibição do retrocesso social é relativamente recente, tendo surgido em consequência da busca por uma efetiva concretização dos direitos sociais constitucionalmente protegidos.

${ }^{148}$ DERBLI, op. cit., p. 182. 
Nada obstante o dissenso na nomenclatura ${ }^{149}$, o princípio da proibição do retrocesso social encontra-se mais desenvolvido em países como a Alemanha, a Itália e Portugal.

$\mathrm{Na}$ Alemanha, a questão da proibição do retrocesso social teve início com a discussão acerca da eficácia dos direitos fundamentais sociais, em especial os de caráter prestacional ${ }^{150}$. Foi em razão de manifestação do Tribunal Federal Constitucional, todavia, que a vedação ao retrocesso social foi enfrentada a partir de um entendimento diverso.

O Tribunal Federal Constitucional alemão identificou a matéria do princípio da proibição do retrocesso social a partir de uma vinculação do sistema de prestações sociais ao direito e garantia fundamental da propriedade, prevista no artigo 14 da Constituição alemã. Entendeu o Tribunal alemão que, da mesma forma que a propriedade do pós guerra era protegida em seu aspecto patrimonial e de conteúdo, por ser considerada base para o sustento do indivíduo, o mesmo entendimento poderia ser aplicado às prestações da seguridade social, que visavam, primordialmente, a garantia da existência do titular do direito subjetivo. E se para a propriedade vigorava a proibição do retrocesso (supressão) do direito, o mesmo se aplicaria às questões de seguridade social. ${ }^{151}$

Na Itália, a questão do retrocesso social também foi reconhecida pelo Direito Constitucional, principalmente em razão das doutrinas de Balladore Pallierie Gustavo

\footnotetext{
${ }^{149}$ Proibição do retrocesso social, vedação de retrocesso social, princípio do não retrocesso social, princípio do não retorno da concretização, proibição da contra revolução social ou da evolução reacionária etc. (DERBLI, op. cit., p. 199).

150 "Na medida em que os direitos sociais dependem da atuação do legislador para sua efetivação, a ausência de qualquer atividade nesse sentido é inadmissível, além de ser proibida a supressão de lei que regulamente ou venha regulamentar direitos fundamentais sociais". (DERBLI, op. cit., p. 137-139).

151 "Ainda no que diz com a proteção de posições jurídico-subjetivas de natureza pública por meio da garantia fundamental da propriedade, o Tribunal Federal Constitucional, já em arestos anteriores, entendeu que esta proteção tem por pressuposto a circunstância de que ao titular do direito é atribuída uma posição jurídica equivalente à da propriedade privada e que, no caso de uma supressão sem qualquer compensação, ocorreria uma colisão frontal com o princípio do Estado de Direito, tal como plasmado na Lei Fundamental. Paradigmática é, portanto, a virtual equiparabilidade das posições subjetivas de direito público com a condição de proprietário. Com a inclusão de direitos subjetivos patrimoniais de natureza pública na esfera da seguridade social no âmbito de proteção da garantia fundamental da propriedade, verificou-se uma ampliação do conceito de propriedade vigente no direito privado, do qual o conceito constitucional de propriedade acabou por se desprender quase que completamente." (SARLET, Ingo Wolfgang. O Estado Social de Direito, a Proibição de Retrocesso e a Garantia Fundamental da Propriedade. Revista Eletrônica sobre a Reforma do Estado (RERE). ${ }^{\circ}$ 9. Salvador: Instituto Brasileiro de Direito Público, março/abril/maio, 2007. Disponível em

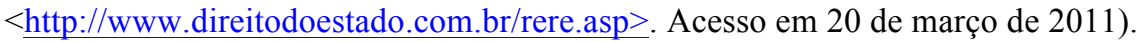


Zagrebelsky $^{152}$, que defenderam a impossibilidade de o legislador retroagir a um estágio anterior à concretização ou regulamentação de um direito social, o qual invariavelmente prescinde de uma posição ativa por parte do mesmo. ${ }^{153}$

Foi em Portugal, porém, que a questão do retrocesso social ganhou maior destaque, principalmente em razão da contribuição do constitucionalista José Joaquim Gomes Canotilho. Em seu livro Constituição Dirigente e Vinculação do Legislador, publicado em $1982^{154}$, Canotilho defendeu que os direitos econômicos, sociais e culturais apresentam uma dimensão subjetiva, dentro de uma metódica constitucional, resultante

a) da consagração constitucional destes direitos como direitos fundamentais dos cidadãos e não apenas como "direito objectivo" expresso através de "normas programáticas" ou de "imposições constitucionais" (direitos originários de prestações); b) da radicação subjectiva de direitos através da criação por lei, actos administrativos, etc., de prestações, instituições e garantias necessárias à concretização dos direitos constitucionalmente reconhecidos. É neste segundo sentido que se fala de direitos derivados a prestações (assistência social, subsídio de desemprego, etc.) que justificam o direito de judicialmente ser reclamada a manutenção do nível de realização e de se proibir qualquer tentativa de retrocesso social. ${ }^{155}$

E Canotilho ainda vai além ao desenvolver a institucionalização da proibição do retrocesso social a partir do princípio da democracia econômica e social ${ }^{156}$ ao asseverar que uma vez conquistados direitos sociais e econômicos, eles se tornam uma garantia institucional na medida em que representam uma pretensão dos cidadãos contra as entidades públicas sempre que for dificultada ou obstada sua realização. Deste modo, é estabelecida uma proibição de "evolução reacionária" direcionada aos órgãos do Estado e que justifica sanção de inconstitucionalidade das normas que visem a eliminar as conquistas sociais. ${ }^{157}$

\footnotetext{
152 "A todo esto sería necesario, sin embargo, añadir, en lo que concierne a la libertad del legislador, que estas proclamaciones constitucionales orientadas hacia la expansión de los "derechos" de los particulares, sirven al menos para impedir a la ley dar marcha atrás en relación al nivel alcanzado por estos derechos en un momento anterior." (ZAGREBELSKY, Gustavo. El Tribunal Constitucional Italiano. In FAVOREU, Louis et. alii. Tribunales Constitucionales Europeos y Derechos Fundamentales. Madrid: Centro de Estudios Constitucionales, 1984. p. 450)

${ }^{153}$ DERBLI, op. cit., p. 161-165.

${ }^{154} \mathrm{Em} 1^{\mathrm{a}}$ edição.

${ }^{155}$ CANOTILHO, José Joaquim Gomes. Constituição Dirigente e Vinculação do Legislador. $2^{\mathrm{a}}$ ed. Coimbra: Coimbra Editora, 2001. p. 374. (grifos no original).

${ }^{156}$ DERBLI, op. cit., p. 145.

157 "O princípio da democracia económica e social aponta para a proibição de retrocesso social. A ideia aqui expressa também tem sido designada como proibição de "contra-revolução social" ou da "evolução reaccionária". Com isto quer dizer-se que os direitos sociais e económicos (ex.: direito dos trabalhadores, direito à assistência, direito à educação), uma vez obtido em determinado grau de realização, passam a constituir, simultaneamente, uma garantia institucional e um direito subjetivo. (...) A violação do núcleo essencial
} 
Seguindo o mesmo entendimento, o Tribunal Constitucional português reconheceu a existência do princípio da proibição do retrocesso social em uma paradigmática decisão, declarando a inconstitucionalidade de lei infraconstitucional (art. 17 do Decreto 254, de 29 de junho de 1982) que revogara grande parte da Lei $\mathrm{n}^{\circ}$ 56, de 15 de setembro de 1979, que dispunha sobre o Serviço Nacional de Saúde de Portugal. O relator do acórdão, Conselheiro Vital Moreira, afastou a tese de inconstitucionalidade formal e passou à análise da inconstitucionalidade material de tal dispositivo revogador, fundamentando seu entendimento de que a criação do Serviço Nacional de Saúde era uma forma de realização do direito fundamental social de proteção à saúde e, como tal, exige prestações positivas do Estado, sem que, com isso, lhe seja negada a jusfundamentalidade. Deste modo, conclui que se a própria Constituição determinou a criação de uma lei para realizar um direito fundamental, é vedado ao legislador revogar essa lei, retornando ao estado de coisas anterior. ${ }^{158159}$

efectivado justificará a sanção de inconstitucionalidade relativamente a normas manifestamente aniquiladoras da chamada “justiça social”"'. (grifos no original) (CANOTILHO, José Joaquim Gomes. Direito Constitucional e Teoria da Constituição. 7. ed. Coimbra: Almedina, 2003. p. 338-339).

158 "Se a Constituição impõe ao Estado a realização de uma determinada tarefa - a criação de uma certa instituição, uma determinada alteração na ordem jurídica —, então, quando ela seja levada a cabo, o resultado passa a ter a proteção directa da Constituição. O Estado não pode voltar atrás, não pode descumprir o que cumpriu, não pode tornar a colocar-se na situação de devedor. Quando, por exemplo, em cumprimento do artigo $101 .^{\circ},{ }^{\circ}{ }^{\circ}$, da Constituição, que ordenava a extinção do regime de colónia, este veio a ser efectivamente extinto, o Estado não pode, posteriormente, vir a revogar a extinção da colónia e a restaurar essa figura. Se o fizesse, incorreria em violação positiva do artigo 101. ${ }^{\circ}$ da Constituição. (...) É que aí a tarefa constitucional a que o Estado se acha obrigado é uma garantia do direito fundamental, constitui ela mesma objecto de um direito dos cidadãos. Quando a tarefa constitucional consiste na criação de um determinado serviço público (como acontece com o Serviço Nacional de Saúde) e ele seja efectivamente criado, então a sua existência passa a gozar de protecção constitucional, já que a sua abolição implicaria um atentado a uma garantia institucional de um direito fundamental e, logo, um atentado ao próprio direito fundamental. A abolição do Serviço Nacional de Saúde não significa apenas repor uma situação de incumprimento, por parte do Estado, de uma concreta tarefa constitucional; uma vez que isso se traduz na revogação da execução dada a um direito fundamental, esse acto do Estado implica uma ofensa ao próprio direito fundamental. Em grande medida, os direitos sociais traduzem-se para o Estado em obrigação de fazer, sobretudo de criar certas instituições públicas (sistema escolar, sistema de segurança social, etc.). Enquanto elas não forem criadas, a Constituição só pode fundamentar exigências para que se criem; mas após terem sido criadas, a Constituição passa a proteger a sua existência, como se já existissem à data da Constituição. As tarefas constitucionais impostas ao Estado em sede de direitos fundamentais no sentido de criar certas instituições ou serviços não o obrigam apenas a criá-los, obrigam-no também a não aboli-los uma vez criados. Quer isto dizer que a partir do momento em que o Estado cumpre (total ou parcialmente) as tarefas constitucionalmente impostas para realizar um direito social, o respeito constitucional deste deixa de consistir (ou deixa de consistir apenas) num obrigação positiva, para se transformar (ou passar também a ser) numa obrigação negativa. O Estado, que estava obrigado a actuar para dar satisfação ao direito social, passa a estar obrigado a abster-se de atentar contra a realização dada ao direito social. (...) Impõe-se a conclusão: após ter emanado uma lei requerida pela Consumição para realizar um direito fundamental, é interdito ao legislador revogar essa lei, repondo o estado de coisas anterior. A instituição, serviço ou instituto jurídico por ela criados passam a ter a sua existência constitucionalmente garantida. Uma nova lei pode vir alterá-los ou reformá-los nos limites constitucionalmente admitidos; mas não pode vir extingui-los ou revogálos". (Tribunal Constitucional Português. Acórdão n 39/84. Lisboa, 11 de abril de 1984. Disponível em $<$ http://w3.tribunalconstitucional.pt/acordaos/Acordaos84/1-100/3984.htm >. Acesso em 14 de maio de 2011.

${ }_{159}$ Esse julgamento contou com três votos divergentes proferidos por Joaquim Costa Aroso, José Manuel Cardoso da Costa e Messias Bento. Joaquim Costa Aroso defendeu que no caso em análise não houve retrocesso 
Essa decisão sacramentou, em um primeiro momento, a posição da doutrina portuguesa sobre o retrocesso social ${ }^{160}$. E estabeleceu a notável diferença com relação à tese elaborada na Alemanha, que embasava tal princípio a partir da existência de uma contribuição pecuniária de seu titular.

Posteriormente, a doutrina alemã passou a ter maior influência no pensamento constitucional português, estabelecendo-se um debate acerca da observância, pelo legislador, das imposições legislativas constitucionais. Surge, portanto, a questão da proteção ao núcleo essencial dos direitos fundamentais, primeiramente, sob o âmbito da limitação da reversibilidade dos direitos adquiridos e das expectativas de direito e, posteriormente, defendendo a liberdade de atuação e legitimidade do legislador para estabelecer os parâmetros infraconstitucionais dos direitos sociais, a partir de decisões políticas, desde que tais decisões

social, mas tão somente repristinação da pressuposta inconstitucionalidade por omissão anterior à lei sobre o Serviço Nacional de Saúde, na medida em que a simples normação da parte organizacional do Serviço não pode ser entendida como garantia institucional, como se a lei tivesse adquirido força constitucional, principalmente porque não chegou sequer a ser implantado. Portanto, não atinge o direito fundamental à saúde. José Manuel Cardoso da Costa defendeu que para haver retrocesso social duas situações dever estar amplamente demonstradas: (i) que o princípio constitucional em causa seja suficientemente claro e afirmativo para que dele se possa retirar indicação inequívoca da direção e sentido a se seguir e os meios a serem utilizados em sua efetivação; e (ii) que a revogação ocorrida tenha gerado a aniquilação de uma situação jurídica e institucional que já tenha criado a sua volta um consenso social radicado na consciência jurídica geral a convicção de sua obrigatoriedade constitucional. No caso analisado, a estrutura organizativa do Serviço Nacional de Saúde sequer chegou a ser implantada, não tendo, portanto, sua revogação promovido a destruição ou aniquilação de qualquer conteúdo constitucional. Messias Bento, por sua vez, defendeu que, em razão do Serviço Nacional de Saúde jamais ter sido criado (subjetivado), não se pode falar em extinção de um direito que apenas existiu no papel (na letra da lei). Ademais, ainda que assim não fosse, ressaltou que os direitos fundamentais, inclusive sociais, sempre admitem restrições - respeitado o conteúdo essencial dos respectivos preceitos constitucionais -, uma vez que a total vinculação do legislador equivaleria a atribuir-lhe, num primeiro momento, poderes constituintes, para logo em seguida, remetê-lo a uma função meramente executiva, surrupiando-lhe as verdadeiras características da função legislativa: liberdade constitutiva e autorevisitabilidade. Por fim, completou: "a concepção de Constituição, que um tal entendimento das coisas pres-suporia, é, no entanto, uma concepção que, de todo, não perfilho: a Lei Fundamental, tal como a entendo, não se pode confundir com um mero programa de governo; há-de ser antes - e sempre - um quadro nor-mativo, aberto à criatividade e à inventiva do poder democrático. Há-de permitir a este que - empenhado na criação de condições de justiça social, capazes de possibilitar a cada homem uma cada vez mais completa reali-zação da sua personalidade - rasgue caminhos vários que cada um, atento às exigências do bem comum, possa livremente percorrer em busca do seu próprio modelo de bem-estar." (Tribunal Constitucional Português. Acórdão n ${ }^{\circ}$ 39/84. Lisboa, 11 de abril de 1984. Disponível em <http://w3.tribunalconstitucional.pt/acordaos/Acordaos84/1-100/3984.htm>. Acesso em $14 \mathrm{de}$ maio de 2011.

160 "Essa proibição de retrocesso, segundo Gomes Canotilho e Vital Moreira, pode ser considerada uma das consequências da perspectiva jurídico-subjetiva dos direitos fundamentais sociais na sua dimensão prestacional, que, neste contexto, assumem a condição de verdadeiros direitos defesa contra medidas de cunho retrocessivo, que tenham por objeto a sua destruição ou redução". (SARLET, Ingo Wolfgang. A Eficácia dos Direitos Fundamentais: uma teoria geral dos direitos fundamentais na perspectiva constitucional. 10 ed. rev. atual. e ampl. Porto Alegre: Livraria do Advogado, 2009. p. 440). 
não gerem restrições arbitrárias que atinjam o conteúdo essencial do direito à existência mínima garantida pela dignidade da pessoa humana. ${ }^{161}$

$\mathrm{Na}$ doutrina pátria, a discussão sobre a questão do retrocesso social é recente, tendo ganhado força, contudo, após a promulgação da Constituição de 1988.

No plano doutrinário, o constitucionalista José Afonso da Silva estabeleceu em seus estudos a existência de um direito subjetivo negativo, no qual encontra-se viabilizada a impugnação de toda e qualquer medida que esteja em confronto com a Constituição ou que, supervenientemente, subtraia de uma norma constitucional a concretização que já lhe havia sido conferida previamente pelo legislador. ${ }^{162}$ Nessa medida, ainda que indiretamente, admitiu a existência de uma proibição constitucional ao retrocesso, a partir de uma análise das normas constitucionais programáticas (que apenas se limitam a estabelecer determinações, exigindo uma atuação do legislador para que possam produzir efeitos).

No mesmo sentido, Luís Roberto Barroso defende o reconhecimento da vedação do retrocesso na ordem jurídica brasileira, nada obstante a ausência de uma previsão expressa. Em seu entendimento:

Por este princípio, que não é expresso, mas decorre do sistema jurídicoconstitucional, entende-se que se uma lei, ao regulamentar um mandamento constitucional, instituir determinado direito, ele se incorpora ao patrimônio jurídico da cidadania e não pode ser arbitrariamente suprimido. ${ }^{163}$

Tal posicionamento demonstra que uma vez satisfeito um direito, este transforma-se em um direito de defesa perante o Estado, que, por sua vez, deve se abster de atentar contra ele.

Embasado nessa perspectiva de reconhecimento de um princípio implícito da proibição do retrocesso social na ordem constitucional brasileira, Ingo Sarlet ainda aponta vários argumentos de matriz jurídico-constitucional dos quais decorrem a aplicação da vedação ao retrocesso, a fim de consolidar o posicionamento de sua aplicação na sistemática

\footnotetext{
${ }^{161}$ DERBLI, op. cit., p. 154.

${ }^{162}$ SILVA. José Afonso da. Aplicabilidade das Normas Constitucionais. 6.ed. São Paulo: Malheiros, 2002. p. 158.

${ }^{163}$ BARROSO, Luís Roberto. O Direito Constitucional e a Efetividade de suas Normas. 9.ed. Rio de Janeiro: Renovar, 2009. p. 152.
} 
jurídica brasileira, especialmente para os direitos sociais, de cunho prestacional: o princípio do Estado Democrático e Social de Direito, que impõe um mínimo de segurança jurídica para proteger e dar continuidade à ordem jurídica vigente ${ }^{164}$; o princípio da dignidade da pessoa humana, que demanda satisfação de uma vida digna a todos, inviabilizando a criação de medidas que desvirtuem essa noção ${ }^{165}$; o princípio da máxima eficácia e efetividade das normas definidoras dos direitos fundamentais, estabelecido no artigo $5^{\circ}, \S 1^{\circ}$ da Constituição de 1988, que estabelece a maximização da proteção dos direitos fundamentais; as determinações constitucionais que preveem proteção contra medidas retrocessivas; entre outros. ${ }^{166167}$

Em sentido contrário, Felipe Derbli defende que não é possível utilizar os princípios da segurança jurídica e da dignidade da pessoa humana como fundamentos para o princípio da proibição do retrocesso social, na medida em que tal procedimento conduziria ao reconhecimento de um caráter instrumental ao mesmo, o que não reflete a realidade. Para este autor, o princípio da proibição do retrocesso judicial possui caráter finalístico próprio, qual

\footnotetext{
${ }^{164}$ Felipe DERBLI aponta que o princípio do retrocesso social não necessariamente deve estar associado ao princípio da segurança jurídica. Isso porque seus objetos de normatização são distintos. "A questão da preservação da certeza e da previsibilidade do ordenamento jurídico não se confunde com o problema da manutenção do padrão de concretização dos direitos fundamentais sociais atingido por obra do legislador; é até possível que se contrarie a proibição de retrocesso social mesmo sem prejuízo à segurança jurídica." (DERBLI, op. cit., p. 218).

${ }^{165}$ Quanto à questão da associação da dignidade da pessoa humana e retrocesso social, Felipe DERBLI também apresenta posição conflitante, ao defender que "seria um exagero encarar como sendo diretamente contrária ao princípio da dignidade da pessoa humana toda e qualquer afronta do legislador aos direitos fundamentais, como se o mencionado princípio fosse a panacéia para todos os males da sociedade. Ao revés, a tentativa de abarcar todas as situações da vida relacionadas com os direitos fundamentais com o princípio da dignidade humana ampliaria demasiadamente o seu sentido e alcance, com sensível prejuízo para a sua eficácia e para a sua efetividade - no afã de disciplinar tudo, não disciplinaria nada." (Ibid., p. 211).

${ }^{166}$ SARLET, op. cit., p. 446-447.

${ }^{167}$ No mesmo sentido: "Dessa forma, a partir dos pressupostos da Hermenêutica Filosófica, consideram-se como primeiros passos para a atribuição de sentido ao Princípio da Proteção do Retrocesso Social, denunciar: 1) que Segurança Jurídica que o Estado Democrático de Direito visa conferir às relações sociais não se exaure nas categorias conceituais do Direito Adquirido; 2) que o instituto do "Direito Adquirido", considerado de forma objetificada, foi a solução encontrada pelo pensamento liberal (e atualmente, pela dogmática jurídica) para conferir estabilidade ao sistema, fundado na clássica noção de subsunção do conceito primordial-fundante ao fato concreto; 3) que, em face da transformação da sociedade, os pressupostos iluministas não perduram, o que importa em uma inadequação do pensar dogmático às necessidades de contemporaneidade; 4) que tal inadequação, somada ao desconhecimento do caráter transformador do Estado Democrático de Direito por parte dos intérpretes, leva à utilização do instituto do "Direito Adquirido" a consubstanciar-se em uma "capa de verdade", onde todas as situações que não subsumam ao seu conceito estariam desprotegidas pelo sistema; 5) que no Paradigma do Estado Democrático de Direito a subsunção cede espaço à ideia da Ponderação dos Princípios Constitucionais e o formalismo à ideia de materialização dos Direitos Fundamentais; 6) que uma correta atribuição de sentido ao Princípio da Proibição do Retrocesso Social somente é possível com a ponderação do Princípio da Segurança Jurídica, do Princípio da Confiança, do Princípio da Máxima Efetividade das normas constitucionais com vistas à consecução do objetivo maior do Estado, que a consecução do Princípio da Dignidade da Pessoa Humana." (CONTO, Mário de. O Princípio da Proibição do Retrocesso Social: uma análise a partir dos pressupostos da hermenêutica filosófica. Porto Alegre: Livraria do Advogado Editora, 2008. p. 88-89).
} 
seja, garantir a observância do grau de concretização do direito já conquistado, impedindo, comissivamente, o retorno a um nível anterior de ausência de legislação regulamentadora. Nessa medida, apresenta uma posição eminentemente substantiva. ${ }^{168169}$

$\mathrm{Na}$ seara jurisprudencial, por outro lado, a aplicação do princípio da proibição do retrocesso social tem sido menos incisiva. No Supremo Tribunal Federal, a temática foi objeto de pronunciamento pela primeira vez apenas em 2004, e, mesmo, assim, em um voto vencido do Ministro Sepúlveda Pertence. ${ }^{170}$

${ }_{169}^{168}$ DERBLI, op. cit., p. 220-221.

${ }^{169}$ Ao que rebate Ingo Wolfgang SARLET ao salientar, primeiramente, que o instituto da segurança jurídica, em uma constituição consagradora de direitos fundamentais sociais, não pode ficar limitada à mera tutela dos direitos adquiridos ou da irretroatividade de medidas públicas, mas, sim, apresentar-se em sintonia com a tutela plena e promoção dos direitos fundamentais em geral, inclusive sociais. Ademais, por atuar o princípio da proibição do retrocesso social como balizador para a impugnação de medidas que levem à abolição ou à restrição de direitos sociais concretizadores da dignidade da pessoa humana, sua aferição depende também de critérios adicionais, como a proteção da confiança, o mínimo existencial, além da própria noção de dignidade humana. Porém, nem por isso terá tal princípio caráter meramente instrumental, mas tão somente abre-se a possibilidade de analisar a proibição do retrocesso social em sentido amplo, em constante diálogo com outros institutos constitucionais. (SARLET, Ingo Wolfgang. Segurança Social, Dignidade da Pessoa Humana e Proibição de Retrocesso: revisitando o problema da proteção dos direitos fundamentais sociais. Direitos Fundamentais Sociais. Org. José Joaquim Gomes Canotilho, Marcus Orione Gonçalves Correia e Érica Paula Barcha Correia. São Paulo: Saraiva, 2010. p. 79).

170 "De outro lado, a preliminar, nos termos peremptórios em que articulada, vai de encontro a um dogma da teoria contemporânea da Constituição: o de que toda norma constitucional, mesmo as despidas de eficácia plena e ainda as ditas programáticas, tem positividade jurídica imediata, que se manifesta - assinala Canotilho (Direito Constitucional, $5^{\text {a }}$ ed., 1991, p. 190) - não apenas em sentido afirmativo, como "vinculação do legislador, de forma permanente, à sua realização" e como "diretrizes materiais permanentes" a tomar "em consideração em qualquer dos momentos da atividade concretizadora (legislação, execução, jurisdição)", mas também que "como limites negativos, justificam a eventual censura, sob a forma de inconstitucionalidade, em relação aos atos que as contrariam". No Brasil, essa eficácia negativa de tais normas, já a evidenciara o ensaio clássico de José Afonso da Silva (Aplicabilidade das Normas Constitucionais, ed. RT, 1968, p. 114 ss), com observações de ajustada pertinência ao caso. Assim é que - versando sobre as "normas constitucionais de princípio institutivo", categorias de sua classificação em que caberia encartar a do art. 194, par. ún,. VII, CF ora invocado - assinala com precisão o notável mestre mineiro das Arcadas paulistas (op. cit, p. 122): “...ao surgir uma Constituição, como a nossa, muitas das leis, referidas em suas normas de eficácia limitada, já existem, e isso tem importância prática, porque tais leis preexistentes, integrativas, não poderão mais ser revogadas pura e simplesmente, pois, aí, se terá uma atividade legislativa inconstitucional e sujeita ao controle jurisdicional. Essa assertiva tem seu fundamento no fato de que a discricionariedade do legislador, diante das normas constitucionais de eficácia incompleta, só se verifica quanto à iniciativa da lei integrativa; emitida esta (a preexistência a isso se equivale), a questão passa a ser jurídico-constitucional, visto ter a lei aderido ao ditame da Lei Maior, com o que não é mais permitido constitucionalmente, sendo, no entanto, facultado ao legislador modificar a lei, desde que mantenha seus termos na conformidade do princípio ou esquema que lhe ditou o constituinte." Na mesma trilha, Luís Roberto Barroso (O Direito Constitucional e a Efetividade de suas Normas, $2^{\mathrm{a}}$ ed., Renovar, 1993, p. 112): “As normas constitucionais programáticas, dirigidas que são aos órgãos estatais, hão de informar, desde o seu surgimento, a atuação do Legislativo, ao editar leis, bem como a da Administração e do Judiciário ao aplicá-las, de ofício ou contenciosamente. Desviando-se os atos de qualquer dos Poderes da diretriz lançada pelo comando normativo superior, viciam-se por inconstitucionalidade, pronunciável pela instância competente". E adiante: "Objetivamente, desde o início de sua vigência, geram as normas programáticas os seguintes efeitos imediatos: (A) revogam os atos normativos anteriores que disponham em sentido colidente com o princípio que substanciam; (B) carreiam um juízo de inconstitucionalidade para os atos normativos editados posteriormente, se com elas incompatíveis." O mesmo cabe dizer em tese, mutatis mutandis, da viabilidade da argüição posta nesta ação direta, malgrado aqui a lei cuja "revogação pura e simples" se tacha de inconstitucional, por violar o referido art. 194, VII, CF, seja posterior à Lei Fundamental 
Verifica-se, portanto, que a questão do retrocesso social encontra-se bastante difundida na doutrina estrangeira, e encontrando um espaço cada vez maior dentro do contexto do Direito Constitucional pátrio.

O reconhecimento da aplicação do princípio da proibição do retrocesso social significa impedir que a efetividade da Constituição seja frustrada, limitando que a atuação do legislador infraconstitucional seja realizada em contrariedade à vontade do Poder Constituinte originário. Assim, o texto constitucional, além de estabelecer tarefas ao Estado no sentido de criar instituições ou serviços para realizar um direito fundamental de cunho social, obriga também a sua não abolição uma vez criados. ${ }^{171}$

O princípio da vedação do retrocesso social proclama, portanto, que uma vez realizado o direito fundamental social a partir da regulamentação infraconstitucional, ou seja, uma vez integrado seu conteúdo no ordenamento jurídico a fim de garantir sua eficácia e aplicabilidade, torna-se incabível qualquer reversão dessa medida sem que seja realizada uma nova regulamentação substitutiva ou equivalente. ${ }^{172}$

Torna-se, portanto, premente a utilização de um mecanismo que garanta a observância do grau já conquistado de definição constitucional e concretização infraconstitucional dos direitos fundamentais sociais. Um mecanismo que, se não fundamentado pelos princípios da

\footnotetext{
vigente. Pouco importa. Certo, quando, já vigente à Constituição, se editou lei integrativa necessária à plenitude da eficácia, pode subsequentemente o legislador, no âmbito de sua liberdade de conformação, ditar outra disciplina legal igualmente integrativa do preceito constitucional programático ou de eficácia limitada; mas não pode retroceder - sem violar a Constituição - ao momento anterior de paralisia de sua efetividade pela ausência da complementação legislativa ordinária reclamada para implementação efetiva de uma norma constitucional. Vale enfatizar a esclarecer o ponto. Ao contrário do que supõem as informações governamentais, com o admitir, em tese, a inconstitucionalidade da regra legal que a revogue, não se pretende emprestar hierarquia constitucional à primeira lei integradora do preceito da Constituição, de eficácia limitada. Pode, é óbvio, o legislador ordinário substituí-la por outra, de igual função complementadora de Lei Fundamental; o que não pode é substituir a regulação integradora precedente - pré ou pós-constitucional - pelo retorno ao vazio normativo que faria retroceder a regra incompleta da Constituição à sua quase impotência originária" (grifos no original) (Supremo Tribunal Federal. Ação Direta de Inconstitucionalidade n ${ }^{\circ}$ 2065/DF. Relator Ministro Maurício Corrêa. Ementa publicada no Diário da Justiça em 06 de junho de 2004. Disponível em $<$ http://www.stf.gov.br>. Acesso em 11 de maio de 2011).

${ }^{171}$ SARLET, op. cit., p. 447.

172 "Em outras palavras, cumprida a deliberação constitucional no sentido da concretização dos direitos fundamentais sociais, o legislador infraconstitucional torna-se vinculado, não lhe sendo lícito eliminar os direitos implementados, sem oferecer mecanismos de recomposição do respectivo direito social. Este já se engloba no "patrimônio social" daquela coletividade ou categoria." (MARTINS, Patricia do Couto Abbud. A Proibição do Retrocesso Social como Fenômeno Jurídico. In GARCIA, Emerson (org.). A Efetividade dos Direitos Sociais. Rio de Janeiro: Editora Lumen Juris, 2004).
} 
segurança jurídica e da confiança, já que substantivo, possa ser considerado corolário desses ideais ${ }^{173}$, visando à manutenção do Estado Democrático de Direito. E esse mecanismo surge justamente com o reconhecimento de um princípio que inviabilize o retrocesso social.

Enfim, proibição de retrocesso não significa apenas inviabilizar a eliminação do direito fundamental do texto constitucional, mas engloba também evitar uma conduta comissiva do legislador, no sentido de promover a extinção ou a redução, - ainda que tácita de leis infraconstitucionais que prevejam, regulamentem ou ampliem direitos fundamentais sociais, sem que seja acompanhada de uma nova regulação que a substitua ou que resguarde a proteção previamente alcançada, garantindo sempre uma concretização progressiva de tais direitos.

\subsubsection{Posicionamentos contrários versus fundamentos}

Em contrariedade à aplicação do princípio da proibição de retrocesso social, utilizamse vários argumentos, que, no entanto, podem ser rebatidos com a análise dos fundamentos da aplicação do princípio da proibição do retrocesso social. O presente estudo, ater-se-á apenas àquelas posições divergentes que, de algum modo, enfocam questões vinculadas à busca que ora se propõe.

Um primeiro argumento contrário à utilização do princípio do retrocesso social é que a definição do núcleo essencial dos direitos fundamentais sociais - o que se visa proteger com tal vedação - é, em verdade, realizada pelo legislador infraconstitucional, a partir de uma decisão política. Deste modo, a liberdade de atuação englobaria a autonomia de rever as decisões tomadas previamente, sendo tal autonomia limitada apenas pelo princípio da confiança e pela obrigatoriedade de motivação e justificação das medidas restritivas. ${ }^{174}$ É o que garante o princípio da democracia.

O princípio da democracia é dito como entrave à aplicação do princípio da proibição do retrocesso social em razão do entendimento de que a democracia exige espaço para a atuação do legislador, no sentido de impor a realização de medidas e decisões importantes

\footnotetext{
173 “O Princípio da Segurança Jurídica e da Confiança no Estado Democrático, ligados ao Princípio da Proibição do Retrocesso Social, apresentam maior profundidade, na medida em que visam coibir não só as medidas de cunho retroativo, mas notadamente as medidas de cunho retrocessivo." (CONTO, op. cit., p. 92).

${ }^{174}$ SARLET, op. cit., p. 443.
} 
politicamente, de forma a garantir o pluralismo e a alternância no poder. Assim, a impossibilidade de revisibilidade de questões sociais, principalmente diante de fatores econômicos e, até mesmo sociais, impede a escolha de prioridades a partir do juízo de conveniência e oportunidade, e, consequentemente, atinge o espaço de conformação do legislador, inviabilizando a democracia. ${ }^{175}$

Inicialmente, cabe salientar que, em razão de todo o analisado até o presente momento, não se pode admitir ser outorgado ao legislador tal poder extremo de estabelecer o conteúdo essencial dos direitos fundamentais sociais, mesmo porque confrontaria a própria limitação constitucional de reforma do texto maior. Ademais, conferir ao legislador infraconstitucional a autonomia de delimitar o ponto essencial dos direitos fundamentais sociais baseada em decisões de cunho meramente político atinge frontalmente a segurança jurídica e a confiança que deve permear as relações entre o Estado Democrático de Direito (que exige a submissão do próprio exercício democrático do poder às normas jurídicas) e o indivíduo. ${ }^{176}$

E mesmo que assim não fosse, o reconhecimento da fundamentalidade dos direitos sociais implica o reconhecimento de uma necessária vinculação do legislador, de forma a proteger tais direitos de uma ampla liberalidade legislativa. Ora, o objetivo da fundamentalidade é justamente retirar tais direitos da esfera de disponibilidade do legislador, uma vez que não podem se sujeitar às conveniências políticas.

Além disso, a própria Constituição, em uma acepção de sistema de regras e princípios, na qual estes funcionam como elemento unificador de todo o sistema constitucional,

\footnotetext{
175 “A objeção fundada no princípio democrático contra uma proibição de retrocesso na seara dos direitos sociais parte da afirmação de que democracia exige espaço de conformação para o Legislador, espaço que envolva decisões importantes para a comunidade política e se abra a diversos projetos, numa perspectiva pluralista e possibilitadora de alternância no poder. [...] Neste contexto, não haveria como, sem aniquilar o princípio democrático, proibir o Legislador de, uma vez emanada legislação concretizadora de direitos sociais, alterá-la de modo a retroceder no nível de concretização alcançado. Uma tal proibição representa uma cristalização da ordem jurídica, com retirada de espaço de conformação do Legislador e de sua capacidade de autorreversibilidade em prejuízo da democracia e do pluralismo, além de não se coadunar com os condicionantes fáticos que pesam sobre os direitos sociais." (NETTO, op. cit., p 139).

176 “Além disso, mediante a supressão pura e simples do próprio núcleo essencial legislativamente concretizado de determinado direito social (especialmente dos direitos sociais vinculados ao mínimo existencial) estará sendo afetada, em muitos casos, a própria dignidade da pessoa, o que desde logo se revela inadmissível, ainda mais em se considerando que na seara das prestações mínimas (que constituem o núcleo essencial mínimo judicialmente exigível dos direitos a prestações) para uma vida condigna não poderá prevalecer até mesmo a objeção da reserve do possível e a alegação de uma eventual ofensa ao princípio democrático e da separação dos poderes." (SARLET, op. cit., p. 444).
} 
estabelece conteúdos necessários, conteúdos permitidos e conteúdos proibidos, limitando, já neste aspecto, o espaço de conformação do legislador para escolhas de ordem política. ${ }^{177}$

Nesta esteira, se se compreende constitucionalmente adequada a existência de imposições concretas dirigidas ao Legislador para garantir eficácia aos direitos sociais, parece desarrazoado compreender também constitucionalmente adequada a proibição dirigida ao Legislador de retroceder na garantia desta eficácia, proibindo-se o retrocesso social. ${ }^{178}$

Deste modo, não é possível identificar o conflito entre a proibição do retrocesso social e a democracia, na medida em que não impede a revisão de leis, inviabilizando a atividade do legislador. Ao contrário, o princípio da proibição do retrocesso social exige uma fundamentação para tais revisões, de tal forma a apresentar-se idoneamente necessário diante de novas circunstâncias fáticas, sem, contudo, desconsiderar o grau de concretização legislativa previamente alcançado. ${ }^{179}$

Outro argumento contrário à aplicabilidade da proibição ao retrocesso social relacionase com a suposta identidade entre retrocesso social e omissão do legislador. Tal questão resume-se ao entendimento de que com o retrocesso social haveria um retorno ao status quo de ausência de concretização da norma constitucional, equivalendo-se, portanto, a uma omissão legislativa.

Muito embora seja possível - e lógico - se reconhecer que "tanto o retorno na concretização de normas constitucionais quanto a ausência de ato infraconstitucional concretizador $a b$ initio signifiquem o descumprimento de imposição legiferante" ${ }^{\text {"180 }}$, não se pode conferir a ambos o mesmo tratamento. Isso porque apesar da correlação não há equivalência entre os dois institutos.

A inconstitucionalidade de uma lei por ofensa ao princípio da proibição do retrocesso social decorre de um ato comissivo, de agressão a normas constitucionais. Ou seja, já se vislumbra, na norma constitucional, um mínimo garantido, de modo que a nova lei deverá obrigatoriamente respeitá-lo, sob pena de ser considerada inconstitucional. Já a

\footnotetext{
${ }^{177}$ NETTO, op. cit., p. 144.

178 Ibid.

${ }^{179}$ DERBLI, op. cit, p. 291.

${ }^{180}$ Ibid., p. 266.
} 
inconstitucionalidade por omissão demanda a ausência de qualquer medida por parte do legislador, no sentido de não realizar o mínimo por ela previamente determinado.

Em suma: a proibição do retrocesso social evita justamente retornar à condição de omissão previamente existente. Mas com ela não se confunde, na medida em que, para sua observância, alguma parte da realização da norma já foi concretizada. Portanto, a confusão nessas definições não encontra qualquer respaldo fático ou jurídico.

Por fim, no que concerne à questão da reserva do possível, comumente utilizada para fundamentar a limitação da eficácia do texto constitucional, também não se pode vislumbrar justificativa para o afastamento do princípio da proibição do retrocesso social.

Reserva do possível, em uma definição simplificada, é

o condicionamento fático da concretização dos direitos fundamentais à existência de recursos financeiros para suportar os custos destes direitos, ou seja, fundamenta que se admita que um direito social não se concretize pela ausência de recursos, e obviamente, também se presta a embasar a compressão ou mesmo supressão da concretização de direitos sociais. ${ }^{181}$

Considerando, pois, a reserva do possível como inviabilizador da ampla e irrestrita concretização dos direitos sociais, em decorrência dos custos necessários para sua implementação e manutenção, esse argumento se torna um obstáculo à aplicação do princípio da proibição do retrocesso social, na medida em que seriam justificados retrocessos em circunstâncias de escassez de recursos ou mudanças no cenário econômico.

É indiscutível que a concretização de direitos fundamentais - principalmente os de cunho social - gera custos ao Estado. Porém, não se pode utilizar esse argumento para comprometer a eficácia de um mínimo necessário à prestação de um direito constitucionalmente garantido. Eventuais condições fáticas podem influenciar na verificação dos níveis de proteção ou até, excepcionalmente, no processo de realização dos direito. Contudo, não há o que se justificar a ideia da reserva do possível dentro do núcleo essencial do direito fundamental.

${ }^{181}$ NETTO, op. cit., p. 144. 
Observa-se, assim, que dentro dessa perspectiva, que reserva do possível e retrocesso social não detém aplicações contrapostas, mas convivem em uma relação de tensão a ser resolvida a partir de critérios de razoabilidade e proporcionalidade.

Sem desconhecer a existência da condicionante fática mencionada, nem a necessidade de guiar as prestações estatais por critérios de proporcionalidade e razoabilidade, considera-se que a reserva do possível não tem o condão de afastar legitimamente a concretização, pelo menos, do núcleo essencial dos direitos fundamentais - garantindo um mínimo de exequibilidade para as normas constitucionais que os preveem -, com destaque, aqui, para os direitos sociais, mais diretamente atingidos pela invocação dessa cláusula. ${ }^{182}$

Por outro lado, a utilização da reserva do possível deve ser ponderada conjuntamente com os princípios da segurança jurídica e da máxima efetividade das normas constitucionais, devendo ser considerada para fins de elevação do nível de realização da norma e não, simplesmente, como forma de justificar a aplicação de medidas retrocessivas. ${ }^{183}$

Portanto, se a reserva do possível não legitima o enfraquecimento da aplicabilidade dos direitos fundamentais sociais, retirando-lhe o seu mínimo essencial, não pode ser considerada um obstáculo para a utilização de um princípio de proibição do retrocesso social.

Verificada a ausência de qualquer incompatibilidade entre os princípios da democracia e da reserva do possível e o princípio da proibição do retrocesso social, bem como a ausência de equivalência deste último com a omissão legislativa, a questão que se apresenta premente relaciona-se com o alcance dessa proibição de retrocesso social. Isso porque essa proteção não pode assumir um caráter absoluto sob pena de se, aí sim, atingir a autonomia da função legiferante.

\subsubsection{Do alcance do conceito de retrocesso social}

Muito embora os fundamentos contrários não sejam suficientes para embasar o afastamento de um princípio da proibição do retrocesso social, alguns dos argumentos lançados podem ser utilizados para se apurar a amplitude da proteção trazida pelo conceito de retrocesso social.

\footnotetext{
${ }^{182}$ NETTO, op. cit., p. 163.

${ }^{183}$ CONTO, op.cit., p.94.
} 
Em função do princípio da democracia (pluralismo político), que garante a discricionariedade do legislador na escolha das formas de concretização do direito fundamental social ${ }^{184}$, denota-se que a proteção contra o retrocesso não pode assumir um caráter absoluto, principalmente no que concerne às prestações. A ideia de uma proibição absoluta do retrocesso social vai de encontro à possibilidade de opções discricionárias por parte do legislador, promovendo um engessamento da função legislativa.

Ademais, a aceitação de um feição absoluta para a proibição do retrocesso social obstaculizaria a necessária revisão que é fundamental à atividade legislativa, além de impedir a constante reavaliação que deve ser realizada para implementação das metas de ação do Estado e para avaliação do desempenho das mesmas, para garantir a efetivação dos direitos sociais. $^{185}$

Não se pode encarar a proibição do retrocesso como tendo a natureza de uma regra geral de cunho absoluto, já que não apenas a redução da atividade legislativa à execução pura e simples da Constituição se revela insustentável, mas também pelo fato de que esta solução radical, caso tida como aceitável, acabaria por conduzir a uma espécie de transmutação das normas infraconstitucionais em direito constitucional, além de inviabilizar o próprio desenvolvimento deste. ${ }^{186}$

Deste modo, diante da sistemática do Estado Democrático de Direito, motivador do princípio da confiança e da segurança jurídica, e da garantia da observância dos mínimos sociais alcançados dentro de uma máxima eficiência e efetividade das normas de direitos fundamentais sociais, é possível conferir a possibilidade de aplicação de uma reversibilidade relativa ao princípio da proibição do retrocesso social, adstrita, por óbvio, à total e irrestrita proteção ao núcleo essencial, este, sim, conforme já apontado, de caráter absoluto.

Por outro aspecto, a aceitação de uma visão relativa para a proibição do retrocesso social também acaba por liquidar o entendimento de que o princípio da proibição do retrocesso social encontra óbice no princípio da reserva do possível. Isso porque a interpretação da reversibilidade relativa do retrocesso social atende a perspectiva da realização de ajustes nos programas legais de forma a garantir o cumprimento da máxima

\footnotetext{
${ }^{184}$ MARTINS, Patrícia do Couto Villela Abbud. A Proibição do Retrocesso Social como Fenômeno Jurídico. $A$ Efetividade dos Direitos Fundamentais. Coord. Emerson Garcia. Rio de Janeiro: Lumen Juris, 2004. p. 409.

${ }^{185}$ SARLET, op. cit., p. 448.

${ }^{186}$ Ibid., p. 449.
} 
eficácia possível dos direitos fundamentais dentro de uma limitação dos recursos financeiros, sempre pautado na busca pela garantia da proteção dos direitos fundamentais sociais já alcançados.

Em suma e até mesmo em função de classificação como princípio, a proibição do retrocesso social não pode assumir um caráter geral e absoluto, podendo o direito fundamental social ser objeto de revisões pelo legislador, como consequência de uma discricionariedade que é inerente à sua atividade.

A partir dessa primeira análise dos contornos do alcance do princípio da proibição do retrocesso social, é preciso apurar, portanto, a forma de se aferir os limites de aplicação deste princípio.

O principal alcance (e, consequentemente, objetivo) para a aplicação de uma proteção contra o retrocesso social é garantia do núcleo essencial, cujo conceito já foi visitado neste trabalho. Mesmo diante da admissão de um caráter relativo à sua observância, a proibição do retrocesso social vai até o limite da proteção ao núcleo essencial e ao nível de conformação por ele já assegurado. Assim, é o núcleo essencial e sua concretização a primeira barreira de vinculação do legislador para não realização de retrocesso social, uma vez que tal noção está intimamente conectada ao princípio da dignidade da pessoa humana.

Nessa medida, é preciso ter em mente que eventuais revisões não podem atingir o núcleo essencial do direito fundamental nem os mínimos de concretização já atingidos, sob pena de se caracterizar o retrocesso.

Superada a questão da necessária manutenção do núcleo essencial e do grau mínimo de conformação conseguido, outra forma de amplitude deve estar indispensavelmente vinculada à noção de proteção contra o retrocesso social.

É fato que a proibição do retrocesso social vai além das simples vedações a medidas retroativas trazidas pelos institutos da coisa julgada, do direito adquirido e do ato jurídico perfeito. Isso porque, conforme já incansavelmente mencionado, visa, primordialmente, à garantia da manutenção e efetividade dos direitos fundamentais sociais. 
Dentro dessa perspectiva, toda e qualquer medida restritiva de direitos sociais deve ser encarada com reservas e sob uma presunção, ainda que relativa, de inconstitucionalidade, estando sujeita a um exame de justificativa e proporcionalidade, sempre à luz da dignidade da pessoa humana. ${ }^{187}$

Portanto, a proibição do retrocesso social alcançará a necessária averiguação, dentro da liberdade de escolha legislativa, da justificativa comprovável da alteração, considerando critérios de proporcionalidade e, sob nenhuma hipótese, poderá autorizar a modificação arbitrária, discriminatória ou ofensiva da garantia do direito a um mínimo de existência digna.

Toda e qualquer medida que apresente, ainda que minimamente, caráter retrocessivo, deverá ser constitucionalmente justificada, a partir da ponderação “entre a agressão (dano) provocada pela lei restritiva à confiança individual e a importância do objetivo almejado pelo legislador para o bem da coletividade". ${ }^{188}$

Nota-se, por mais uma vez, a importância da utilização do critério da proporcionalidade dentro de uma concepção de efetividade de direitos fundamentais. Todavia, neste momento, a regra da proporcionalidade tem como função impedir a realização de uma proteção insuficiente ou incompatível com as exigências da garantia da dignidade da pessoa humana, garantindo a aplicabilidade do princípio da proibição do retrocesso social para esses casos.

Diante dessas considerações, tem-se que o alcance da proibição do retrocesso social atinge duas vertentes: a primeira, a própria noção de núcleo essencial e do nível mínimo de concretização do direito fundamental social já atingido, não sendo autorizada qualquer medida que viole esses parâmetros. E a segunda é a necessidade de justificativa constitucional da medida, de modo que seja feita a análise proporcional da viabilidade do retrocesso versus o bem da coletividade e a garantia de um padrão mínimo de continuidade da ordem jurídica, com vistas à preservação da confiança e da segurança jurídica.

Em última análise, a proteção contra o retrocesso social visa garantir que o Estado assegure "de modo eficiente - nunca menos do que uma vida com dignidade para cada

\footnotetext{
${ }^{187}$ SARLET. op. cit., p. 453-454.

${ }^{188}$ Ibid., p. 456.
} 
indivíduo e, portanto, uma vida saudável para todos os integrantes (isolada e coletivamente considerados) do corpo social."189

\subsection{A Constituição dirigente: instrumento de realização da justiça social}

Nada obstante a prévia existência prática de uma constituição de cunho dirigente, este termo somente foi apresentado à doutrina jurídica no ano de 1982, quando o jurista José Joaquim Gomes Canotilho, em sua tese de doutoramento, retoma aspectos da concepção de dirigismo contratual apontada por Peter Lerche ${ }^{190}$ com o objetivo de identificar a força normativa da Constituição de Portugal de 1976.

Assim, o livro Constituição Dirigente e Vinculação do Legislador: contributo para a compreensão das normas constitucionais programáticas foi criado para defender a razão de ser de uma Constituição promulgada em decorrência de um movimento revolucionário (Revolução dos Cravos) e que promoveu a ruptura política com o regime ditatorial anterior, com uma profunda alteração na estrutura jurídico-constitucional do país. ${ }^{191}$

A Constituição Portuguesa de 1976, em sua redação original de metanarrativas emancipatórias $^{192}$, trouxe disposições que estabeleciam um regime social, econômico e jurídico bem diferente do anteriormente visto no país, com expressões que enalteciam a revolução ocorrida e a busca por uma sociedade socialista ${ }^{193}$. Essa Carta Maior teve como principal característica a identificação dos valores e conquistas democráticos e a esperança de modificação da realidade da sociedade portuguesa daquele período. "O contexto apelava para o esforço de conferir juridicidade ao programa constitucionalmente projetado, apesar do reconhecimento de pontos de tensão entre a plataforma normativa e a dinamicidade do processo político."194

\footnotetext{
${ }^{189}$ SARLET. op. cit., p. 457.

${ }^{190}$ Concepção criada em 1961, defende que a Constituição possui quarto partes distintas: normas de princípio; direitos, garantias e divisão de competências; dispositivos garantidores do fim e determinações de direção constitucional.

${ }^{191}$ OLIVEIRA. Fábio de. A Constituição Dirigente: Morte e Vida no Pensamento do Doutor Gomes Canotilho. Revista Brasileira de Direito Comparado. número 28. Rio de Janeiro: Instituto de Direito Comparado LusoBrasileiro, 2005. p. 199.

${ }^{192}$ CANOTILHO. José Joaquim Gomes. Constituição Dirigente e Vinculação do Legislador: contributo para a compreensão das normas constitucionais programáticas. 2. ed. Coimbra: Coimbra Editora, 2001, prefácio, p. IX.

${ }^{193}$ Posteriormente, tais menções foram alteradas em razão de sucessivas revisões constitucionais.

${ }^{194}$ OLIVEIRA. op. cit., p. 199.
} 
Diante desse quadro, nada mais natural que a defesa de uma Constituição dirigente, que se apresenta por meio de um conteúdo pragmático-constitucional no qual é atribuído ao Estado a realização de fins e consecução de tarefas. Portanto, essa concepção de Constituição não se restringe à distribuição de competências estatais ou à proteção dos direitos individuais, mas ergue-se como legitimadora de um verdadeiro Estado Democrático de Direito, que como tal, deve se apresentar como um Estado de efetiva justiça social.

Para Canotilho, as normas constitucionais devem definir as tarefas e finalidades do Estado com vistas ao atingimento da justiça social, sob pena de tal objetivo sujeitar-se à vontade do grupo político dominante em detrimento daquilo que a sociedade deseja. Desse modo, a legitimidade da Constituição repousa na definição de um estatuto de organização de um plano normativo geral entre Estado e sociedade. ${ }^{195}$

Portanto, baseado nessa interpretação, o legislador deve pautar sua atuação pelos preceitos constitucionais.

O bloco constitucional dirigente cuida, na verdade, de vincular o legislador negativa e positivamente, na medida em que, quanto ao primeiro aspecto, the veda a edição de normas que lhe contrariem o conteúdo material e, quanto ao segundo, estabelece um dever jurídico de criar as leis necessárias à concretização do comando constitucional.

(...)

É através do bloco constitucional dirigente que, para além da limitação à direção política, se institui o fundamento constitucional para a política, fornecendo-se um impulso diretivo material permanente e, para o legislador, uma exigência de atuação."196

\footnotetext{
195 "O problema nuclear da legitimação de uma ordem constitucional deriva do facto de a constituição, como complexo normativo, consagrar um "domínio" e apontar "fins" políticos. Como se justifica e conserva esse domínio? Pelo "poder"? Pelo "consenso"? Uma "ordem constitucional" deve "construir-se" através de uma praxis comum, conscientemente escolhida, ou deve "reconstruir-se" mediante o estabelecimento de regras e pressupostos de comunicação, de modo a atingir-se um "consenso" entre participantes livres e iguais? E qual o "contexto" para a realização deste consenso? O status quo social? O "sistema"? Uma "praxis revolucionária"? Qualquer que seja a resposta, o problema da dignidade de reconhecimento de uma ordem constitucional não é um problema de fundamentação dos "fins últimos", mas o de explicitar, na medida do possivel, a "pretensão de legitimidade", através da fixação dos fins e tarefas que incumbem ao Estado e do estabelecimento da forma de derivação do poder estadual. Eis porque é um problema de legitimação o fenómeno da "dinamização da constituição, expresso, entre outras coisas, a consagração de "linhas de direcção", na tendência para "sujeitar" os órgãos de direcção política à execução de "imposições constitucionais", na mudança de "compreensão" dos direitos fundamentais e na constitucionalização de direitos económicos, sociais e culturais (direitos a prestações)." (grifos no original) (CANOTILHO, op. cit., p. 18-19).

${ }^{196}$ DERBLI, op. cit., p. 48-56. (grifos no original)
} 
Nessa medida, as imposições constitucionais vinculam o legislador de três diferentes formas: por meio da realização dos preceitos constitucionais impositivos (não há análise do se para o ato legislativo); por meio da concretização das matérias objeto da imposição legislativa (o quê do ato legiferante) e por meio de diretivas materiais também contidas nas imposições legislativas e em outros preceitos constitucionais para os quais o legislador pode ser remetido, de forma expressa ou implícita (o como da legislação). ${ }^{197}$

Isso, contudo, não significa que o legislador não possua liberdade de atuação. A atividade legislativa é, em uma constituição dirigente, vinculada às determinações constitucionais, aos fins prescritos no texto constitucional. Porém, o legislador deve utilizar-se de determinantes autônomas com o objetivo de selecionar os meios mais adequados à consecução do fim proposto pela Constituição, a partir de juízos de proporcionalidade. ${ }^{198}$

Vale ressaltar que a tarefa de concretização das normas constitucionais dirigentes não é adstrita a uma função de governo ou do parlamento, "mas recorta-se como tarefa global de planificação, fixação e execução dos fins constitucionalmente normativizados", sendo, na realidade, uma "tarefa constitucional de direção política". 199

A execução-actualização dos preceitos constitucionais dirigentes é mais do que acto de legislação; é um processo complexo de regulação que através de leis e regulamentos, de actos de planeamento, de linhas políticas e instruções, e na forma de iniciativa, programação, coordenação e integração, exige a participação activa de vários órgãos constitucionais. Radica já nesta ideia a necessidade de substituir a expressão imposições legiferantes pela fórmula imposições constitucionais e de perpectivar o problema da concretização destas imposições como um problema de direcção politica."200

Dentro dessa perspectiva de uma constituição dirigente, em que o legislador (ou qualquer órgão constitucional de direção política) vincula-se à implementação das imposições

\footnotetext{
197 "É assim: (1) a existência de uma ordem material permanente e concreta dirigida essencialmente ao legislador, no sentido de este emanar os actos legislativos concretizadores; (2) o dever de o legislador regular positivamente as matérias contidas nas imposições; (3) o dever de o legislador "actuar" os preceitos impositivos, Segundo as directivas materiais neles formuladas." (CANOTILHO, op. cit., p. 316).

198 "Não se pense que o cumprimento do programa constitucional não permita alternativas ou variáveis de decisão política, porque, embora esta não seja normativamente desvinculada, também não é meramente induvidosa, rígida, automática ou de execução ao concretizar os valores constitucionais." (OLIVEIRA, op. cit., p. 201). (grifos no original)

${ }^{199}$ CANOTILHO, op. cit., p. 178.

${ }^{200}$ Ibid., p. 179. (grifos no original)
} 
constitucionais $^{201}$, o não cumprimento de tais disposições, a partir de uma abstenção do legislador apresenta os contornos de uma agressão de tal maneira gravosa, que assemelha-se a uma ofensa direta à norma constitucional de direito fundamental. ${ }^{202}$

E será justamente no âmbito dos direitos fundamentais sociais que essa questão do não cumprimento das imposições legislativas se apresentará mais importante, haja vista que tais direitos demandam prestações positivas do Estado (e consequentemente do legislador) para sua garantia e proteção.

E é dentro desse contexto que surge o princípio da proibição do retrocesso social, diretamente relacionado com a efetivação permanente e progressiva dos direitos sociais em prol da justiça social, a partir da preservação daqueles já realizados. Nessa medida,

o dirigismo constitucional carrega não só o dever inescusável do legislador de editar os atos que dêem concretude à Constituição - especialmente no sentido da redução das desigualdades sociais -, como também o dever de observar o padrão obtido na consecução, por impulso legislativo, do desiderato constitucional de desenvolvimento da cidadania. ${ }^{203}$

Tal princípio decorre ainda da dimensão subjetiva dos direitos econômicos, sociais e culturais, apontada por Canotilho ao tratar das diretivas constitucionais que reconhecem direitos prestacionais. É a partir da radicação subjetiva de tais direitos por meio da formulação legislativa de prestações e garantias necessárias à sua concretização que se justificam "o direito de judicialmente ser reclamada a manutenção do nível de realização e de se proibir qualquer tentativa de retrocesso social." ${ }^{204}$

Nada obstante a genialidade dos ensinamentos de Canotilho, o ilustre doutrinador português surpreendeu seus seguidores ao apresentar, pouco mais de vinte anos após sua grande obra, um artigo no qual refuta grande parte de sua teoria, chegando a alardear a morte

\footnotetext{
201 “(...) mas, por outro lado, é admissível e exigível a aplicação imediata dos preceitos constitucionais, sempre que isso possa ser feito sem mediação legislativa, e neste caso, pode dizer-se que as imposições constitucionais se dirigem também ao juiz e à administração." (CANOTILHO, op. cit., p. 295-296).

202 "(...) a omissão legislativa inconstitucional significa que o legislador não "faz" algo que positivamente lhe era imposto pela constituição. Não se trata, pois, apenas de um simples negativo "não fazer"; trata-se, sim, de não fazer aquilo a que, de forma concreta e explícita, estava constitucionalmente obrigado." (Ibid., p. 331). (grifos no original)

${ }^{203}$ DERBLI, op. cit., p. 83.

${ }^{204}$ CANOTILHO, op. cit., p. 374.
} 
da Constituição dirigente, deixando órfãos vários ordenamentos jurídicos seguidores desse modelo constitucional.

Tal artigo, denominado Rever ou Romper com a Constituição Dirigente? Defesa de um Constitucionalismo Moralmente Reflexivo, traduz uma reflexão do autor acerca de certos conceitos expostos em sua tese de doutoramento, com a proposta de uma reformulação do dirigismo e da programaticidade constitucionais. ${ }^{205}$

Mencionado artigo, posteriormente transformado em prefácio da $2^{\mathrm{a}}$ edição de seu paradigmático livro sobre a constituição dirigente, sustenta que a Constituição não pode se resumir a um mero instrumento de governo, entregando-se à estrutura processual toda a determinação de seu fundamento material (conteúdo).

Para entender a mudança no pensamento jurídico do mestre lusitano, há que primeiro se verificar as circunstâncias históricas da ocasião, que, inclusive, foi relevante na percepção de uma nova visão para a teoria da constituição.

Do mesmo modo que a adoção de um modelo programático foi consequência de um pensamento emancipatório (textos constitucionais narrativamente emancipatórios) decorrente do declínio do governo ditatorial ocorrido em Portugal no fim da década de 70 (e também no Brasil no início da década de 80), a revisão da criação de Canotilho baseou-se em novos acontecimentos político-culturais que modificaram o pensamento jurídico e apresentaram uma visão eminentemente pós-modernista que não mais sustentavam um dirigismo constitucional.

Nessa medida, os textos constitucionais dirigentes inseriam-se em um movimento de modernidade projetante, no qual havia a crença na capacidade transformadora das normas constitucionais sobre a realidade. ${ }^{206}$ Contudo, com o decorrer do tempo, o desmoronamento dos sistemas socialistas (que mais depositavam pretensões na programaticidade emancipatória das constituições dirigentes), a queda do Muro de Berlim, a globalização econômica e o neoliberalismo, novos questionamentos foram surgindo, conduzindo a uma crise da política regulativa, cuja vinculatividade exacerbada e pretensão utópica de dirigir a sociedade ${ }^{207}$

\footnotetext{
${ }^{205}$ DERBLI, op. cit., p. 56.

${ }^{206}$ CANOTILHO, op. cit., p. VI.

${ }^{207}$ DERBLI, op. cit., p. 58.
} 
acabaram por rechaçar a aplicabilidade de uma constituição dirigente e levaram seu maior defensor a repensar suas concepções anteriores.

Portanto, diante do novo quadro histórico que se descortinou, Canotilho passa a defender uma relativização da constitucionalidade dirigente, de forma a permitir a busca por alternativas políticas viáveis, a partir de programas políticos dos vários governos possíveis ${ }^{208}$, porém, sem negar a "vinculação aos programas constitucionais como impulsionadores normativos do progresso social". 209

Ao defender a evolução de seu pensamento, Canotilho demonstra que o dirigismo constitucional está em crise baseado em duas principais premissas: as constituições dirigentes cristalizam a política, convertendo o direito em instrumento funcional da direção exclusiva da sociedade pelo Estado (norma constitucional conformando autoritariamente a sociedade); o autismo nacionalista e patriótico de tais constituições, que se mantêm presas a um conceito de soberania, que não se encaixa no atual contexto de político-organizatório internacional.

A partir da primeira premissa, vislumbra-se a dificuldade da constituição dirigente se adequar a novos problemas surgidos, como à conformação da esfera jurídica a âmbitos e práticas sociais diferentes, ao surgimento de novos sujeitos do poder, como as entidades organizativas e os atores neocorporativos, à impossibilidade de gerar um conjunto de respostas racionais e coerentes ao conjunto complexo e crescente de demandas e exigências decorrentes do sistema social; ao surgimento de novos universos paralelos (mercado, empresa, tecnologias); às inovações jurídicas (novos direitos sociais); entre outros. ${ }^{210}$

Já na segunda premissa, observa-se a necessidade de adequação da força normativa constitucional à supra nacionalização e a internacionalização do direito com as liberdades globalizadas. $^{211}$

Diante dessa crise que se apresenta (a partir de um novo contexto histórico-políticocultural), Canotilho é taxativo ao sacramentar que

\footnotetext{
${ }^{208}$ OLIVEIRA, op. cit., p. 215.

${ }^{209}$ Ibid., p. 212.

${ }^{210}$ CANOTILHO. op. cit., prefácio, p. XXIII-XXVI.

${ }^{211}$ Ibid., p. XXV.
} 
a Constituição Dirigente está morta se o dirigismo constitucional for entendido como normativismo constitucional revolucionário capaz de, só por si, operar transformações emancipatórias. Também suportará impulsos tanáticos qualquer texto constitucional dirigente introvertidamente vergado sobre si próprio e alheio aos processos de abertura do direito constitucional ao direito internacional e aos direitos supranacionais. ${ }^{212}$

Longe de debater pontualmente as razões que levaram Canotilho a rever seu famoso posicionamento, o presente trabalho tem como objetivo, neste momento, apenas analisar se, de fato, a Constituição dirigente, nos moldes originariamente apresentados, está ultrapassada (para não dizer morta, utilizando a expressão do próprio autor) e de que forma essa análise afeta o estudo do princípio da proibição do retrocesso social, cujo surgimento e desenvolvimento tiveram como elemento norteador as bases de um dirigismo constitucional.

Apesar do primeiro impacto das palavras do Prof. Canotilho ao proclamar a morte da Constituição dirigente, uma análise mais detida sobre a questão permite verificar alguns pontos divergentes dessa constatação.

Logo, preliminarmente, já é possível perceber que o mestre lusitano relaciona a morte da Constituição dirigente com uma definição específica: enquanto normativismo constitucional revolucionário com vistas a transformações emancipatórias. Neste aspecto, já se conclui que, se a Constituição dirigente apresentar viés revolucionário, com vistas a consolidar a força normativa da Constituição, a partir de propósitos socializantes inalcançáveis, sua estrutura não mais se coaduna com o atual momento histórico de harmonia institucional. $^{213}$

$\mathrm{Na}$ acepção de Canotilho, a Constituição dirigente foi um projeto positivado de uma revolução que precisava ser feita e efetivamente foi. Portanto, trata-se de "um produto

\footnotetext{
${ }^{212}$ CANOTILHO, op. cit., p. XXIX. (grifos no original)

213 "Ocorre que a "morte" do dirigismo constitucional anunciada por Canotilho diz respeito exatamente à sua desilusão diante da existência de fórmulas que, por mais que exprimissem o espírito revolucionário no momento constituinte, estabeleceriam promessas utópicas de felicidade que, porquanto inalcançáveis, serviriam apenas para desacreditar a força normativa da Constituição. Vale dizer, uma vez superada a quadra histórica da revolução e consolidadas as instituições democráticas, não caberia mais a positivação, em sede constitucional, de um normativismo revolucionário que atribuísse ao Estado toda a responsabilidade pela condução da vida social. $\mathrm{Na}$ verdade, esse normativismo revolucionário que se adequava a um momento de instabilidade já não seria mais conveniente para uma nova circunstância de harmonia institucional.” (DERBLI, op. cit., p. 66-67). (grifos no original)
} 
acabado de um projeto de modernidade". ${ }^{214}$ Realizado o objetivo para o qual foi criada, a Constituição dirigente está realmente acabada.

Porém, nada obstante essa constatação, Canotilho não afasta por completo ou enfraquece a noção de dirigismo e programaticidade constitucional. Ao contrário, salienta que algumas dimensões importantes merecem ser mantidas, como por exemplo, o necessário enquadramento do legislador (ausência absoluta de liberdade de conformação) aos fins que integram o programa constitucional. ${ }^{215}$

Aliás, a própria criação de organizações supranacionais, apontada como um fator que levou à queda do dirigismo contratual, acabou por corroborar a sobrevivência da diretividade programática, na medida em que grande parte da imperatividade do texto constitucional foi deslocada para os textos internacionais vinculantes.

Deste modo, ainda que se considerem superados a programaticidade e o dirigismo constitucionais, a bem da verdade é que parte dessa estrutura ainda sobrevive, especialmente no que diz respeito à fixação de limites para o legislador quanto ao exercício de sua atividade para a realização do programa constitucional. Por esta razão, admite-se que a Constituição ainda se coloca como um instrumento de governo, como "elemento substancial de vinculação do legislador. A Constituição dirigente ainda é o arcabouço normativo necessário para o desenvolvimento de um projeto de combate à pobreza, mediante esquemas de socialidade." ${ }^{216}$

E é essa estrutura que ainda se faz necessária na realidade brasileira, de forma integral, aliás, nada obstante os defensores da tese de que não é mais possível a aplicabilidade de um dirigismo constitucional (mesmo no Brasil) ${ }^{217}$.

\footnotetext{
214 CANOTILHO. José Joaquim Gomes in COUTINHO, Jacinto Nelson de Miranda (Org.). Canotilho e a Constituição Dirigente. 2. ed. Rio de Janeiro: Renovar, 2005. p. 14.

${ }^{215}$ Ibid., p. 14-15.

${ }^{216}$ DERBLI, op. cit., p. 69.

217 "O discurso em favor da retirada do texto constitucional da sua programaticidade e, consequentemente, da redução da vinculação jurídica do legislador à Constituição baseia-se, em grande parte, no argumento de que o dirigismo constitucional busca substituir-se ao processo de decisão política característico dos regimes democráticos, com a pretensão de ocupar todos os espaços da regulação jurídica da sociedade. Sinaliza-se um retorno à Constituição-garantia do liberalismo, restrita a limitar o poder político e, no máximo, prever os direitos de índole social minimamente necessários à fruição dos direitos de liberdade.” (DERBLI, op. cit., p. 71).
} 
Isso porque, inicialmente, ainda que a Constituições Brasileira e Portuguesa tenham sido desenhadas e promulgadas em contextos históricos semelhantes (redemocratização a partir da derrocada de regimes autoritários), não é possível observar na Constituição Brasileira qualquer propósito revolucionário e socializante, que Canotilho bem frisou como sendo o responsável por uma redefinição de uma constituição de caráter diretivo.

No Brasil, a Lei Maior de 1988 teve como claro objetivo a realização de reformas sociais voltadas à promoção da justiça social e à redução das desigualdades, por meio da instituição plena de um Estado Democrático e Social de Direito, que nada mais é do que a própria promessa de modernidade de uma constituição dirigente (legitimar juridicamente a política a partir de sua racionalização). ${ }^{218}$

Contudo, na realidade brasileira essa promessa de modernidade ainda não foi cumprida, na medida em que os padrões de desenvolvimento social permanecem inaceitáveis (ainda há pobreza, fome, desigualdade e outros males a impedir a sociedade brasileira de atingir a plenitude de seus direitos sociais). Como estão negar a existência de um dirigismo constitucional a garantir a aplicabilidade dos programas sociais constitucionais? Como utilizar os argumentos de um excesso socializante se os direitos sociais sequer são primariamente observados?

Por óbvio que o Brasil ainda se encontra em uma situação na qual não é admissível (ou sequer cogitável) afastar o dever do Poder Público em realizar tarefas com vistas ao atingimento dos fins constitucionais, vinculando-se positiva e negativamente ao cumprimento de sua obrigação. E, curiosamente, é justamente esse o propósito de uma Constituição dirigente: vincular materialmente o agente político a partir de parâmetros previamente estabelecidos, vedando-lhe a realização de determinadas condutas e obrigando-lhe o cumprimento de certas tarefas, direcionando suas ações à consecução das finalidades previstas na própria Constituição. ${ }^{219}$

Em razão dessa situação claramente diferenciada, o questionamento que logo se apresenta é com relação à possibilidade de manutenção de uma categoria absoluta e universal para a teoria da constituição. Neste aspecto, o Professor Canotilho lança dúvida quanto à

\footnotetext{
${ }^{218}$ DERBLI, op. cit., p. 67-69.

${ }^{219}$ Ibid., p. 73.
} 
necessidade de se estabelecer novos diálogos, admitindo teorias das constituições (ou interconstitucionalidade $)^{220}$, a partir da aceitação da existência de problemas políticos e sociais distintos enfrentados por cada Estado. ${ }^{221}$ “A Constituição (e cada Constituição) depende de sua identidade nacional, das especificidades de cada Estado Nacional e de sua inserção no cenário internacional."222

De toda sorte, dentro dessa perspectiva, não há como se afastar o entendimento de que a Constituição Brasileira é uma constituição dirigente e que, à parte das novas teorias desenvolvidas, continua em plena atividade em solo nacional. ${ }^{223} \mathrm{O}$ Brasil ainda não atingiu um grau suficiente de maturidade social que lhe permita relativizar (já que o próprio Canotilho aceitou a manutenção de algumas dimensões da programaticidade constitucional ${ }^{224}$ ) o dirigismo constitucional.

Vale, contudo, salientar que, conforme já mencionado alhures, a aceitação de um bloco constitucional dirigente não significa a imutabilidade absoluta de suas proposições. Uma constituição legítima é uma constituição em consonância com a constante evolução da sociedade e aberta às suas exigências.

A Constituição, portanto, precisa conservar permanente diálogo com a realidade para que se mantenha a sua capacidade de conformação social e, para tanto, é indispensável que se admita a sua evolução, o seu desenvolvimento, para utilizar o termo preferido de Canotilho.

Nessa ordem de ideias, se a Constituição dirigente veicula um projeto contínuo de modernidade, consubstanciado na busca permanente da justiça

\footnotetext{
${ }^{220}$ CANOTILHO in COUTINHO, op. cit., p. 34.

221 Lenio Luiz Streck aponta a existência de uma teoria da constituição dirigente adequada a países de modernidade tardia para justificar a manutenção do dirigismo constitucional. Por esta teoria, a Constituição traria em seu bojo um conteúdo programático-dirigente mínimo, além de mecanismos de acesso à jurisdição constitucional e participação democrática. (STRECK, Lenio Luiz. Jurisdição Constitucional e Hermenêutica. 2. ed. rev. e ampl. Rio de Janeiro: Forense, 2004. p. 133-145.

222 STRECK, op. cit., p. 133.

223 "Quando os esquemas políticos, económicos, sociais e culturais forem totalmente outros, quando as novas gerações não se identificarem com a Constituição, quando a Constituição deixar de ter força reflexiva, isto é, capacidade de conformação da própria realidade social, então ela caduca, ela será substituída, ela acabará por se dissolver nos próprios mecanismos sociais. Em suma: as constituições dirigentes existirão enquanto foram historicamente necessárias." (CANOTILHO in COUTINHO, op. cit., p. 40).

224 "Mas isto não pode significar que não sobrevivam algumas dimensões importantes da programaticidade constitucional e do dirigismo constitucional. (...) Em primeiro lugar, em termos jurídico-programáticos, uma Constituição dirigente - já explicitei isso várias vezes - representa um projecto histórico pragmático de limitação dos poderes de questionar do legislador, da liberdade de conformação do legislador, de vinculação deste aos fins que integram o programa constitucional. Nessa medida, penso que continuamos a ter algumas dimensões de programaticidade: o legislador não tem absoluta liberdade de conformação, antes tem de mover-se dentro do enquadramento constitucional. Esta a primeira sobrevivência da Constituição dirigente em termos jurídicoprogramáticos.” (Ibid., p. 15).
} 
social, há de se entender que as normas constitucionais merecerão exegese renovável de acordo com as exigências da sociedade. ${ }^{225}$

Portanto, dentro da concepção da necessidade de concretização das normas constitucionais pelo legislador, de forma a garantir a manutenção dos níveis de proteção já atingidos na busca pelo atingimento do fim constitucional, denota-se que mantém-se intacta a aplicabilidade do princípio da proibição do retrocesso social.

Se o legislador permanece vinculado a programas governamentais de busca à justiça social, a partir da criação e efetivação dos mesmos, em um cristalino projeto de programaticidade constitucional, suas obrigações não se resumem a efetivar permanente e progressivamente a justiça social, mas também garantir que o padrão de consecução já obtido não seja reduzido ou eliminado.

O compromisso constitucional brasileiro, baseado em premissas do dirigismo e da programaticidade constitucional, com vistas ao desenvolvimento de um projeto de justiça social e de cidadania, não apenas sustenta, mas também exige que o retrocesso social seja terminantemente vedado.

\subsection{O retrocesso social como ofensa à dignidade da pessoa humana}

Conforme já verificado anteriormente, a utilização de um princípio de proibição de retrocesso social tem como primordial objetivo a garantia da proteção e da aplicabilidade dos direitos fundamentais sociais.

Nada obstante tal temática já ter sido tratada logo no início do presente trabalho, cabe neste momento uma breve definição da intrínseca relação entre direitos fundamentais e dignidade humana:

Dignidade da pessoa pode ser definida como sendo "a qualidade intrínseca e distintiva de cada ser humano que o faz merecedor do mesmo respeito e consideração por parte do Estado e da comunidade, implicando, neste sentido, um complexo de direitos e deveres fundamentais que assegurem a pessoa tanto contra todo e qualquer ato de cunho degradante e desumano, como venham a lhe garantir as condições existenciais mínimas para uma vida saudável, além de propiciar e promover sua participação ativa e

\footnotetext{
${ }^{225}$ DERBLI, op. cit., p. 82.
} 
corresponsável nos destinos da própria existência em comunhão com os demais seres humanos. ${ }^{226}$

Denota-se, portanto, que os direitos fundamentais têm grande relevância na certificação da dignidade humana, na medida em que seu reconhecimento e efetivação tem sido constantemente considerados uma exigência para o alcance desta dignidade, bem como para a própria noção de Estado de Direito. Isso decorre do fato de que os direitos fundamentais são desmembramentos da própria dignidade humana, na medida em que esta está intrinsecamente inserida em seus respectivos conteúdos ou, ainda, em suas projeções. ${ }^{227}$

Por esta razão, nada mais lógico do que a efetivação de retrocesso afetar diretamente ao princípio basilar da dignidade da pessoa humana, porquanto objetivo final e primordial dos direitos fundamentais.

Ora, se a existência de retrocesso social afeta diretamente à dignidade humana, haja vista ser estruturada a partir da existência de direitos fundamentais, a proibição, ainda que implícita, de tal retrocesso revela, por via de consequência, um caráter protetivo com vistas à manutenção da dignidade da pessoa humana.

Assim, a proteção garantida aos direitos fundamentais a partir do entendimento de que o retrocesso social é absolutamente vedado no ordenamento jurídico brasileiro, pode revelarse também como um mecanismo de defesa dessa modalidade exclusiva de direitos e solução para a conflituosa relação entre direitos fundamentais sociais e irrevisibilidade das cláusulas pétreas previstas no texto constitucional.

\subsubsection{A proibição como mecanismo de defesa de direitos fundamentais (segurança jurídica)}

Em um primeiro momento, tem-se o entendimento de que a proibição do retrocesso social tem como função a garantia da aplicabilidade dos direitos fundamentais sociais,

\footnotetext{
${ }^{226}$ SARLET. Ingo Wolfgang. A Eficácia do Direito Fundamental à Segurança Jurídica: dignidade da pessoa humana, direitos fundamentais e proibição de retrocesso social no direito constitucional brasileiro. Revista Brasileira de Direito Comparado. número 28. Rio de Janeiro: Instituto de Direito Comparado Luso-Brasileiro, 2005. p. 101.

${ }^{227}$ Ibid., p. 102.
} 
carecedores, em sua essência, de prestações positivas, na medida em que obsta a revisão redutiva das formas de efetivação de tais direitos.

Portanto, defende-se a observância do princípio da vedação do retrocesso com base na simples garantia de ser o último bloco de proteção do direitos sociais contra eventual restrição.

Contudo, ao analisarmos detidamente a definição, forma de atuação e principalmente, o escopo desse princípio, vislumbramos a possibilidade de utilizarmos essa mecânica não só como última barreira de proteção aos direitos fundamentais, mas também como um importante mecanismo de defesa desses direitos na busca pela dignidade da pessoa humana.

Se considerarmos que a dignidade humana somente será observada e protegida em um ambiente com garantia de segurança e tranquilidade, isto é, um ambiente de confiança na estabilidade, clareza, racionalidade e transparência nas posições jurídicas e nos atos do poder público $^{228}$, é possível entender a indispensabilidade da continuidade na ordem jurídica e a legitimidade constitucional das leis para a defesa dos direitos fundamentais que embasam essa dignidade.

Logo, faz-se necessário um patamar mínimo de segurança jurídica no sentido de proteção da confiança na ordem constitucional e jurídica vigente, para que se atinja a máxima eficácia e efetividade das normas definidoras de direitos fundamentais (inclusive sociais), conforme previsto na Carta Magna de 1988.

Esse patamar mínimo de segurança jurídica é garantido pela confiança na irretroatividade de posições jurídicas tomadas, na própria Constituição ou em decorrência dela, de forma a defender os direitos fundamentais reconhecidos e garantidos, viabilizando sua efetividade e impossibilitando a adoção de medidas que visem à restrição ou à extinção de tais direitos e dos efeitos por eles já realizados.

Diante da amplitude dos direitos fundamentais não se pode submeter a segurança jurídica à mera aplicabilidade dos conceitos de direito adquirido, coisa julgada e ato jurídico

${ }^{228}$ SARLET, op. cit., p. 101-103. 
perfeito, exemplificados na Constituição brasileira. Dentro dessa concepção maior é necessário que se vislumbre a segurança jurídica como a crença na importância desses direitos de tal forma que o impedimento à sua completa e irrestrita efetividade conduziria à inviabilização da dignidade humana.

A garantia de irretroatividade com vistas à defesa de uma estabilidade jurídica dos direitos fundamentais é justamente o objetivo da Constituição ao instituir a vedação ao retrocesso social. Nessa medida, segurança jurídica, no sentido de proteção da confiança, guarda estreita relação com a proibição de retrocesso.

\begin{abstract}
Após sua concretização em nível infraconstitucional, os direitos fundamentais assumem, simultaneamente, a condição de direitos subjetivos a determinadas prestações estatais e de uma garantia institucional, de tal sorte que não se encontram mais na (plena) esfera de disponibilidade do legislador, no sentido de que os direitos adquiridos não podem mais ser reduzidos ou suprimidos, sob pena de flagrante infração do princípio da proteção da confiança (por sua vez, diretamente deduzido do princípio do Estado de Direito), que, de sua parte, implica a inconstitucionalidade de todas as medidas que inequivocamente venham a ameaçar o padrão de prestações já alcançado. ${ }^{229}$
\end{abstract}

Apesar de o conceito de segurança jurídica ser bem mais amplo que a noção de proibição de retrocesso social, fato é que há direta ligação entre a manutenção da proteção social e um padrão mínimo de segurança jurídica, porquanto esta é necessária para a confiança na realização daquela, dentro de um Estado Democrático de Direito. ${ }^{230}$

E é essa ligação que embasa a justificativa para a utilização do instituto da vedação ao retrocesso social como mecanismo de defesa dos direitos fundamentais. A proibição de retrocesso não apenas garante a aplicabilidade desses direitos, mas também defende a existência dos mesmos, que poderiam ser atingidos sem uma confiança em sua necessidade e, principalmente, em sua continuidade para a realização da justiça social. Nessa medida, o princípio ora em voga acaba por atuar como relevante fator assecuratório de um padrão mínimo de continuidade dos direitos fundamentais dentro do ordenamento jurídico brasileiro. $^{231}$

\footnotetext{
${ }^{229}$ SARLET, op. cit., p. 117.

230 "É imprescindível que se outorgue ao princípio fundamental da dignidade da pessoa humana, em todas as suas manifestações e aplicações (portanto, também no âmbito da proibição de retrocesso e da correlata noção de segurança jurídica) a sua máxima eficácia e efetividade possível (....).” (Ibid., p. 147).

${ }^{231}$ SARLET, op. cit., p. 144.
} 
As conquistas relativas aos direitos fundamentais não podem ser destruídas, anuladas ou combalidas, por se cuidarem de avanços da humanidade, e não de dádivas estatais que pudessem ser retiradas segundo opiniões de momento ou eventuais maiorias parlamentares. ${ }^{232}$

Aliás, o entendimento de que as prestações garantidoras dos direitos fundamentais sociais devem ser efetivadas dentro de uma concepção de confiança e realização de justiça social é que embasou a criação de uma constituição dirigente, dentro da qual também se fundamenta a vedação ao retrocesso social. É a partir do reconhecimento da imprescindibilidade dos direitos sociais, bem como da consequente necessidade de protegê-lo constantemente para a garantia da dignidade da pessoa humana a partir de uma continuidade da sistemática vigente que o princípio da proibição do retrocesso veio à lume.

Por outro lado, vale relembrar que as posições jurídicas assumidas tanto pelo legislador constitucional, ao positivar os direitos fundamentais, quanto pelo legislador, ao garantir a efetividade dos direitos fundamentais sociais, têm a presunção de boa-fé, de forma que a confiança nessas relações assume um caráter de maior compromisso. Deste modo, a continuidade dos direitos fundamentais a ser viabilizada pelo princípio de proibição do retrocesso social está diretamente vinculada ao atingimento total e irrestrito de condições que garantam a dignidade da pessoa humana. ${ }^{233}$

Em suma: direitos fundamentais são defendidos com a criação de mecanismos que inviabilizem a possibilidade de removê-los do ordenamento jurídico, bem como quando são organizadas formas de garantia e manutenção de sua efetividade e aplicabilidade. A admissão do princípio do não retrocesso social como garantia de sobrevivência dos direitos sociais perante a lei, impedindo mudanças interpretativas ou legislativas que determinem a redução do âmbito de atuação desses direitos, promove a defesa dos direitos fundamentais sociais de forma plena, ao asseverar a concretização dos mesmos em prol da dignidade da pessoa humana.

\footnotetext{
${ }^{232}$ SARLET, op. cit., p. 146.

233 "Importa lembrar aqui o fato de que a proteção da confiança constitui um dos elementos materiais do princípio da boa-fé, tendo por corolário - notadamente no âmbito das relações negociais, o dever da parte de não fraudar as legítimas expectativas cridas pelos próprios atos, o que evidencia a conexão direta da boa-fé com a proteção da confiança no sentido de uma certa auto vinculação dos atos, e portanto, de uma inequívoca relação com a noção de proibição de retrocesso.” (Ibid., p. 106).
} 


\subsubsection{A proibição como solução para o dilema da natureza não pétrea das normas definidoras de direito sociais}

Já é antiga a discussão envolvendo a questão da ausência de caracterização dos direitos fundamentais sociais como cláusulas pétreas, no âmbito da Constituição Federal de 1988.

Nada obstante o entendimento de que os direitos de cunho social são parte integrante do círculo de direitos mínimos necessários à obtenção de uma vida digna, a impossibilidade de serem observados sem a respectiva prestação estatal comumente os leva a uma espécie de segundo plano em hierarquia de importância no rol dos direitos fundamentais. E tal subestimação sustenta-se justamente pelo fato de que o artigo 60 , parágrafo $4^{\circ}$, da Constituição Federal de 1988, ao proibir a proposta emenda que vise ao extermínio de direitos, não se dirige especificamente a modalidade genérica dos direitos fundamentais, mas fazer referência apenas aos direitos e garantias individuais.

Vários doutrinadores e quase a totalidade da jurisprudência já apresentaram diversas justificativas para essa inconsistência do texto constitucional. Defesas que vão do simples erro material (remete ao título II, portanto engloba todos os direitos individuais, coletivos e sociais), passando pela equivalência de todos os direitos fundamentais em prol da dignidade humana e chegando até a alegação de que os direitos sociais, estão, em última análise, também inseridos dentro de um contexto individual e surgiram com o simples objetivo de tentar entender a decisão do legislador e garantir aos direitos sociais a mesma deferência textualmente conferida aos direitos individuais.

Atualmente, encontra-se pacificado o posicionamento do ordenamento jurídico brasileiro quanto à equivalência de todos os direitos fundamentais na busca pelo fundamento maior da República Federativa do Brasil: a dignidade da pessoa humana, nada obstante seja recorrente o debate acerca da razão pela qual o legislador constitucional manteve apenas a referência aos direitos e garantias individuais na garantia da cláusula pétrea, principalmente face ao princípio basilar da hermenêutica jurídica de que não há palavras inúteis no texto constitucional. 
A solução para essa questão pode ser verificada a partir da análise do método utilizado pela Constituição para garantir a inviolabilidade e a irrevisibilidade dos direitos fundamentais. Em outras palavras: é realmente necessária a inclusão de uma cláusula constitucional expressamente indicando os limites de atuação do legislador infraconstitucional no que concerne aos direitos fundamentais ou há outros métodos adequados para tanto?

A normatização de cláusulas pétreas tem como objetivo determinar expressamente o limite material de revisão de algumas questões consideradas primordiais dentro de um ordenamento jurídico em prol da manutenção de um Estado Democrático de Direito. De outro turno, a utilização de tal mecanismo, além de gerar debates acerca do sentido e alcance jurídico e político dessas limitações, ainda abre espaço para discussões acerca da própria amplitude da proteção trazida, principalmente, quando apresenta rol taxativo de itens a serem protegidos, como é o caso da Constituição Brasileira de 1988.

Há de se convir, portanto, que a utilização da terminologia cláusula pétrea reflete uma imprecisão conceitual, gerada pela própria impossibilidade de se definir o alcance concreto. É nessa esteira que constantemente se coloca em questionamento "a necessidade, eficácia, legitimidade e conformação substantiva das cláusulas de irrevisibilidade."234

E a dúvida acerca do método mais adequado de garantir a proteção dos direitos fundamentais baseia-se principalmente no fato de tal cláusula não abarcar expressamente a totalidade de tais direitos. Sua função, conforme assinalada por Canotilho, restringe-se a três circunstâncias: clarificação da positivação constitucional dos limites materiais implícitos, assim chamados núcleos essenciais; individualização das normas constitucionais infringidas a fim de permitir a constante fiscalização jurisdicional das leis de revisão e advertência política e constitucional de projetos de revisão perturbadores dos direitos, liberdades e garantias fundamentais. $^{235}$

Portanto, faz-se necessária a busca de novos mecanismos garantidores da irrevisibilidade dos direitos fundamentais, mecanismos estes que possam ser aplicados irrestritamente a todo e qualquer direito fundamental. Mesmo porque se analisarmos

\footnotetext{
${ }^{234}$ CANOTILHO. José Joaquim Gomes. Estudos sobre Direitos Fundamentais. Coimbra: Coimbra Editora, 2004. p. 141.

${ }^{235}$ Ibid., p. 142-143.
} 
detidamente a definição de cláusula pétrea, denota-se que sua primordial função é proibir qualquer medida tendente a abolir direitos fundamentais. Ou seja, não menciona a possibilidade de tais direitos serem apenas restringidos. Nessas hipóteses qual a solução adequada?

A escolha mais lógica é pela revisitação do conceito de núcleo essencial dos direitos fundamentais, cuja resistência às leis de revisão não se sustentam apenas em decorrência da manifestação expressa de indisponibilidade e intransponibilidade conferidas pelas cláusulas pétreas, mas, sim, pelo seu caráter de "direito superior constitutivo de nossa identidade jurídico-cultural."236

Dentro dessa perspectiva, a utilização das cláusulas pétreas para proteção dos direitos fundamentais por meio da imposição de limites à sua extinção parece não assumir grande importância, salvo se consideradas as funções supra assinaladas.

Em rigor, ela não proíbe a restrição de direitos, liberdades e garantias através de leis de revisão, o que colocaria as leis de revisão com mais limites do que as próprias leis ordinárias restritivas. Impede, porém, que o "legislador constitucional" aproveite a natureza da lei de revisão para ultrapassar o limite de qualquer direito: o núcleo essencial. ${ }^{237}$

Face a esta constatação é correto assumir que a forma mais eficiente de proteção dos direitos fundamentais, a partir de uma visão constitucional de irrevisibilidade, é a utilização do conceito de conteúdo essencial dos direitos fundamentais.

Isso porque a própria proposição de supressão de qualquer direito fundamental (individual, coletivo, social), em sede de revisão constitucional, encontra barreira no núcleo essencial do bem protegido, materialmente inviolável, intransponível e irrevisível.

A utilização do método do núcleo essencial para definição da irrevisibilidade dos direitos fundamentais, inclusive, soluciona a problemática envolvendo a forma de garantir que direitos fundamentais sociais não sejam restringidos em sua efetividade.

\footnotetext{
${ }^{236}$ CANOTILHO, op. cit., p. 142.

${ }^{237}$ Ibid., p. 144.
} 
Conforme mencionado alhures, essa modalidade de direitos fundamentais enfrenta, além da barreira da ausência de previsão expressa no rol dos direitos abarcados pela cláusula pétrea, a dificuldade em se estabelecer os limites de sua restrição, na medida em que são direitos que dependem de prestações para sua aplicabilidade.

E é justamente nesse contexto que o princípio da proibição do retrocesso social surge como substituto para a lacuna deixada pela cláusula pétrea, utilizada por muitos para subestimar os direitos fundamentais sociais, relegando-o a segundo plano.

Mais importante do que o rol fixado no artigo 60, parágrafo $4^{\circ}$ da Constituição Federal de 1988 é a verificação da intransponibilidade do núcleo essencial presente em todos os direitos fundamentais, inclusive nos de cunho social.

Todavia, quando se trata de direitos fundamentais sociais é certo que a efetividade de tais direitos está estreitamente vinculada às prestações garantidoras de sua aplicabilidade. Deste modo, o núcleo essencial desses direitos se amplia até a consecução de seus efeitos, na medida em que o mínimo necessário para sua existência é atrelado à sua realização prática.

Portanto, a condição para a irrevisibilidade dos direitos sociais é que as prestações já alcançadas e garantidas não sejam restringidas ou extirpadas, sem que haja correspondente substituição nos mesmos moldes anteriormente havidos. A inobservância dessa sistemática configura retrocesso social, inclusive em termos de revisão constitucional.

Corolário lógico dessa análise traduz-se na verificação de que a vedação ao retrocesso social garante a proteção ao núcleo essencial dos direitos fundamentais sociais, método mais eficaz que a existência expressa de uma previsão limitada de cláusula pétrea, já que vinculada à mera supressão de direitos, na consecução e proteção de todos os direitos fundamentais refletivos da dignidade humana.

\subsection{Dos efeitos e consequências da proibição do retrocesso social}

Conforme amplamente aduzido anteriormente, o conteúdo da proibição de retrocesso social reside no reconhecimento da vinculação do legislador aos ditames constitucionais relativos aos direitos sociais. Isso significa que, ao alcançar um determinado grau de 
concretização, a norma constitucional de direito social (definidora de conduta comissiva ou omissiva a ser obrigatoriamente seguida) vincula o legislador de forma a impedi-lo de suprimir ou reduzir a concretização atingida sem a imediata criação de mecanismo, no mínimo, equivalente. ${ }^{238}$

Sua função, para além da simples eficácia jurídica das normas de direitos fundamentais, apresenta inquestionável natureza principiológica, decorrente da própria garantia de um mínimo de concretização e do permanente e contínuo desenvolvimento dessa concretização dos direitos fundamentais de cunho social.

A garantia trazida pelo princípio da proibição social desdobra-se em duas vertentes, positiva e negativa. A garantia negativa impede o legislador de reduzir ou suprimir o grau de densidade normativa já atingido pelos direitos sociais, realizado por meio de legislação infraconstitucional concretizadora dos direitos fundamentais sociais constitucionalmente previstos. $^{239}$

E ao alcançar um consenso básico de concretização legal, as normas de direito fundamental social passam, consequentemente, a assumir um status jusfundamental negativo, próprio dos direitos de defesa, oponíveis ao legislador.

O princípio da proibição de retrocesso social gera para os direitos sociais a mesma proteção garantida aos direitos de liberdade, de tal maneira que, uma vez concretizados por leis que, inseridas no consenso básico, provoquem o desenvolvimento dos conteúdos das próprias normas constitucionais, possam os direitos sociais apresentar o status negativus pacificamente reconhecido aos direitos de liberdade. ${ }^{240}$

A garantia positiva traduz-se justamente na constante necessidade de ampliar, de forma progressiva, o grau de concretização dos direitos fundamentais, em consonância com condições fáticas e jurídicas (reserva do possível), uma vez que o mínimo necessário já está devidamente previsto e protegido. É a "imposição da obrigação de avanço social". 241

\footnotetext{
${ }^{238}$ FILETI, Narbal Antônio Mendonça. A Fundamentalidade dos Direitos Sociais e o Princípio da Proibição de Retrocesso Social. Florianópolis: Conceito Editorial, 2009. p. 178.

${ }^{239}$ Ibid., p. 177.

${ }^{240}$ DERBLI, op. cit., p. 297.

${ }^{241}$ FILETI, op. cit., p. 177.
} 
A proibição do retrocesso social, no entanto, tanto em sua modalidade positiva como em sua modalidade negativa, não pode ser considerada a partir da oposição a um ato específico, muito embora direcionada diretamente ao legislador.

Justamente por seu caráter principiológico, sua análise retrospectiva visa apenas e tão somente à preservação do grau de concretização da norma já conquistado, inviabilizando condutas restritivas ou supressivas que atinjam o nível previamente observado. Seus efeitos, nessa medida, não determinam uma engessada descrição de condutas permitidas, obrigatórias ou proibidas.

Por outro lado, reconhecer a existência da proibição do retrocesso social não significa que a atuação legislativa infraconstitucional seja constitucionalizada. Isto é, que a proteção trazida pela legislação infraconstitucional seja necessariamente elevada à categoria de uma norma constitucional.

$\mathrm{Na}$ realidade, o que se verifica nessa circunstância é a possibilidade de um desenvolvimento da proteção constitucional, realizada pela propulsão legislativa e radicada na consciência jurídica coletiva, de forma que inviabilizada sua redução ou supressão sem a correspondente substituição.

Na prática, a aplicação do princípio da proibição do retrocesso social não depende simplesmente de uma postura ativa ou negativa do Poder Legislativo. Seus efeitos terão maior abrangência a partir da cooperação harmoniosa dos poderes na busca da máxima amplitude de materialização das normas constitucionais de direitos fundamentais sociais.

Nessa medida, a vinculação trazida pela proibição de retrocesso social aplica-se a todos os poderes estatais: Legislativo, em sua total acepção - conquanto foco maior da aplicação do princípio; Executivo, a partir de uma administração pública compromissária com políticas públicas condizentes com os objetivos constitucionais; e Judiciário, por meio do controle dos atos dos poderes, adequando-os aos ditames constitucionais dirigentes. ${ }^{242}$

${ }^{242}$ CONTO, op. cit., p. 97. 
No que concerne ao Poder Legislativo, suas atribuições já foram incansavelmente replicadas neste estudo. Mesmo porque a noção de participação do legislador e sua vinculação aos ditames constitucionais são elementos essenciais para o entendimento da própria definição de proibição de retrocesso social.

Nesse sentido, uma vez que a Constituição adquire caráter normativo e dirigente, ocorre a vinculação da atividade estatal a seus princípios. Nesse sentido é que restam evidentes as limitações à conformação legislativa, no sentido de que não há absoluta liberdade para a atuação do poder legislativo, que permanece vinculado aos valores e princípios constitucionais. ${ }^{243}$

$\mathrm{Na}$ mesma medida, os outros poderes do Estado têm suas atividades vinculadas às normas constitucionais garantidoras de direitos fundamentais sociais porquanto também, por óbvio, sujeitos à observância da inteligência da proibição do retrocesso social.

Afastando-se dos conceitos ultrapassados de primazia do interesse público e da estrita legalidade (vinculação compulsória do Poder Público à lei que o criou), o princípio da proibição do retrocesso social exige o surgimento de um Poder Executivo compromissado com um paradigma de Estado Democrático de Direito. ${ }^{244}$

A partir do embasamento do princípio da proibição do retrocesso social pela Constituição Brasileira, num modelo de teoria da constituição dirigente e compromissária, a legalidade e a dicotomia entre Estado e Sociedade assumem novas facetas dentro do papel a ser entabulado pela Administração Pública (aqui entendida como Poder Executivo propriamente dito).

Não é mais possível vislumbrar tais conceitos afastados dos objetivos do Estado Democrático de Direito, que é a dignidade da pessoa humana. Nessa medida, a função do Poder Executivo é promover políticas públicas implementadoras das diretrizes constitucionais, realizando os direitos fundamentais sociais que demandam uma atuação positiva do Estado (avanço social - garantia positiva). É justamente dentro desse contexto que se enquadra a discricionariedade administrativa. ${ }^{245}$

\footnotetext{
${ }^{243}$ CONTO, op. cit., p. 102-103.

${ }^{244}$ Ibid., p. 97-98.

${ }^{245}$ Ibid., p. 99.
} 
Dessa forma, resta claro que o Princípio da Proibição do Retrocesso Social é vinculante às atividades da Administração Pública que, independentemente da ideologia política que adote, está proibida de atentar contra os Direitos Fundamentais implementados. A proteção aos Direitos Fundamentais, além disso, figura como fator de legitimação e deslegitimação da ação administrativa. ${ }^{246}$

Diante de uma Constituição dirigente e compromissária, a Administração Pública deve, necessariamente, adotar a mesma perspectiva constitucionalista. Nesse sentido, o princípio da proibição do retrocesso social também deve ser analisado como elemento legitimador dos atos do Poder Executivo, protegendo o Estado contra medidas retrocessivas advindas por meio de políticas públicas supressoras ou redutoras de direitos sociais.

Dessa forma, a Administração Pública, no paradigma do Estado Democrático de Direito, abandona as leituras tecnificantes e passa a ter o dever (a pré-ocupação) de transformação do status quo através da efetivação e da proteção dos Direitos Fundamentais Sociais. ${ }^{247}$

A terceira esfera do poder, o Judiciário sempre apresentou papel pacificador, no sentido de aplacar os ânimos tensionados dos demais poderes e, ainda, da sociedade. Dentro dessa perspectiva, o Poder Judiciário não interfere nas esferas reservadas aos demais poderes, realizando apenas e tão somente o enquadramento das medidas realizadas pelo Legislativo e pelo Executivo à luz dos ditames constitucionais.

Contudo, dentro de um Estado Democrático de Direito, cujo principal objetivo é a dignidade humana, fundamentada na garantia de direitos fundamentais, essa concepção inicial de Poder Judiciário passa a sofrer alguns ajustes.

O reconhecimento da imperatividade de se proteger os direitos fundamentais constitucionalmente previstos e, mais além, de se garantir um standard mínimo de eficácia e desenvolvimento contínuo, em especial no que concerne aos direitos sociais, trouxe em seu bojo a necessidade de se rever o posicionamento dessa esfera do poder, principalmente em face da aplicação do princípio da proibição do retrocesso social.

\footnotetext{
${ }^{246}$ CONTO, op. cit., p. 100.

${ }^{247}$ Ibid., p. 101.
} 
Nesse sentido, passa o Poder Judiciário a ser visto como "um instrumento de controle entre os poderes, visando à efetivação dos Direitos Fundamentais Sociais e à observância da programaticidade constitucional." 248

A inadequação da atuação dos Poderes Legislativo e Executivo perante os preceitos constitucionais dirigentes, torna o Poder Judiciário responsável pelo controle dos respectivos atos de cada Poder, de forma a garantir a efetividade dos Direitos Fundamentais, em especial de cunho social. Essa postura, consubstanciada pelo reconhecimento da proibição de retrocesso, transforma o Poder Judiciário em um poder intervencionista, na medida em que passa a agir de maneira ativa na adequação dos meios (políticas públicas e legislação) aos fins sociais constitucionais. $^{249}$

\begin{abstract}
A Jurisdição Constitucional assume papel extremamente relevante no Brasil, uma vez que, em face do abismo existente entre realidade social e as promessas da modernidade ainda não cumpridas, o foco de tensão mormente em relação aos Direitos Fundamentais Sociais - tem se deslocado do Poder Judiciário. ${ }^{250}$
\end{abstract}

Portanto, os efeitos de uma proibição de retrocesso social, trazida pela programaticidade constitucional e pela estruturação de um Estado Democrático de Direito, acabam por vincular a atividade estatal nas suas três expressões de poder, diminuindo a conformidade legislativa, dirigindo a atividade executiva e realizando judicialmente os direitos fundamentais a partir de controle das atividades estatais.

Ao longo dos efeitos trazidos pela inteligência do princípio da proibição do retrocesso social, ainda é possível identificar algumas consequências positivas trazidas pelo afastamento de medidas retrocessivas.

Além de garantir a busca a uma plena e irrestrita dignidade para a pessoa humana, a partir do reconhecimento de direitos fundamentais necessários à consecução de tal fím, tais medidas ainda ratificam a força normativa da Constituição, garantindo que as disposições lá existentes atinjam o máximo possível de eficácia e de aplicabilidade.

\footnotetext{
${ }^{248}$ CONTO, op. cit., p. 105.

${ }^{249}$ Ibid., p. 105-107.

${ }^{250}$ Ibid., p. 106-107.
} 
Nessa medida, o reconhecimento de um princípio de proibição do retrocesso social reflete: uma manutenção do núcleo essencial do direito fundamental, com a constante busca do atingimento da eficácia prestacional plena; um meio constitucionalmente legítimo para atingir o objetivo maior do Estado, que é a dignidade da pessoa humana; um último embate de proteção à utilização de alternativas mais gravosas para o direito social; uma garantia à segurança jurídica e à proteção da confiança; uma busca incessante por políticas públicas adequadas à proteção e às tarefas constitucionalmente previstas, com a constante participação social; entre outras consequências.

Desta feita, seja pela sua definição e fundamentação, seja pelos seus efeitos e consequências, a proibição do retrocesso social é medida premente e necessária para manutenção de um Estado Democrático de Direito voltado para a consecução de uma dignidade humana.

\subsection{Antecedentes comparativos: jurisprudência}

Por se tratar de uma discussão relativamente jovem, a questão da proibição do retrocesso social tem encontrado manifestação reduzida nos tribunais brasileiros. Poucas foram as situações em que esse assunto foi trazido à lume como forma de justificar um posicionamento ou até mesmo de demonstrar a constitucionalidade de uma medida.

Nada obstante se tratar de questão há muito discutida na seara do direito social internacional, o Supremo Tribunal Federal do Brasil, última instância judicial do país, somente tratou especificamente sobre o assunto (embora suscitado brevemente em outros casos), em um voto vencido do Ministro Sepúlveda Pertence em um julgamento sobre a constitucionalidade da revogação de artigos das Leis 8.212/91 e 8.213/91, promovendo a extinção do Conselho Nacional de Seguridade Social e dos Conselhos Estaduais e Municipais de Previdência Social.

Muito embora a ação direta de inconstitucionalidade acima mencionada não tenha sido conhecida, sob a justificativa de que a revogação havida se tratava de ato normativo de efeitos concretos, não apta ao controle concentrado de constitucionalidade, uma vez que ausente a 
generalidade e a abstração ${ }^{251}$, o voto vencido do Ministro Sepúlveda Pertence trata especificamente da questão da proibição do retrocesso social pela primeira vez naquela Corte, ao estatuir que, por se tratar a norma constitucional ofendida (caráter democrático e descentralizado da administração da seguridade social) de norma programática, depende de ato legislativo para surtir efeitos, criando para o legislador, como consequência, a obrigação de proceder à sua concretização, além da proibição de realizar qualquer medida que comprometa o grau de eficácia já atingido, sob pena de se configurar retrocesso social. ${ }^{252}$

No mesmo sentido dessa manifestação, outros julgamentos também apresentaram votos tratando da questão do retrocesso social, como forma de embasar o posicionamento adotado. No julgamento do Recurso Especial n ${ }^{\circ} 567.873$ - MG, ocorrido em 10 de fevereiro de 2004, o então Ministro do Superior Tribunal de Justiça Luiz Fux citou um estudo realizado pelo Procurador da República Marlon Alberto Weinchert sobre a existência de retrocesso social quando somente é permitida isenção de IPI para a compra de veículos movidos a álcool por pessoas portadoras de necessidades especiais, para embasar sua decisão em caso semelhante ${ }^{253}$.

No Supremo Tribunal Federal outras decisões foram marcantes para que o princípio da proibição do retrocesso social fosse amplamente analisado e aplicado concretamente com vistas à proteção irrestrita dos direitos fundamentais sociais.

No julgamento da Ação Direta de Inconstitucionalidade $n^{\circ} 3.105 / \mathrm{DF}$ a questão do retrocesso social foi levantada pelo Ministro Celso de Mello, em voto vencido. Frente à busca pela declaração de inconstitucionalidade do artigo $4^{\circ}$, caput e parágrafo único da Emenda Constitucional $n^{\circ} 41 / 2003$, que instituiu a contribuição previdenciária dos servidores públicos inativos e pensionistas, o Ministro Celso de Mello concluiu pela total inconstitucionalidade da norma, sob o argumento de que, por se tratar o direito previdenciário de direito fundamental, está submetido ao princípio da proibição do retrocesso social, o qual impede que as conquistas já alcançadas sejam desconstituídas, ou seja, que os níveis de concretização anteriormente

\footnotetext{
${ }^{251}$ DERBLI, op. cit., p. 19.

${ }^{252}$ Supremo Tribunal Federal. Ação Direta de Inconstitucionalidade ${ }^{\circ}$ 2.065/DF. Relator Ministro Maurício Corrêa. Ementa publicada no Diário da Justiça em 06 de junho de 2004. Disponível em $<$ http://www.stf.gov.br $>$. Acesso em 11 de maio de 2011.

${ }^{253}$ No caso em análise foi deferida a concessão de isenção de IPI para compra de automóvel por pessoa portadora de necessidade especial mesmo quando o veículo não será dirigido pela mesma. (Superior Tribunal de Justiça. Recurso Especial n 567.873/MG. Relator Ministro Luiz Fux. Ementa publicada no Diário da Justiça em 25 de fevereiro de 2004. Disponível em $<$ http://www.stj.gov.br>. Acesso em 20 de janeiro de 2012).
} 
atingidos sejam reduzidos ou suprimidos sem a correspondente implementação de política compensatória. $^{254}$

Também no julgamento do Mandado de Segurança $n^{\circ} 24.875$, no qual foi aduzido o abuso de poder do Ministro Presidente do Supremo Tribunal Federal em razão de ter considerado, para fins de apuração do subsídio-teto, as vantagens pessoais de natureza pro labore facto, em contrariedade ao estabelecido no artigo 37, XV da Constituição Federal, reduzindo, com isso, os proventos de aposentadoria, a questão do retrocesso social foi suscitada. $^{255}$

Ao deferir totalmente a segurança, o Ministro Marco Aurélio de Mello, em voto vencido, aduziu que a percepção da vantagem pessoal se fez a partir da legislação em vigor à época, passando a integrar o patrimônio dos impetrantes como direito e garantia individual, não passíveis de serem atingidos, seja por lei ou por poder de reforma da Constituição. Deste modo, ao ser alcançado um benefício a título de vantagem pessoal, protegido pela Constituição Federal, o mesmo não pode ser objeto de retrocessão, sob pena de se "grassar a mais absoluta insegurança no tocante a algo já integrado ao patrimônio do cidadão. ${ }^{256}$

Sobre esse julgamento, vale ainda salientar o voto do Ministro Celso de Mello, que, apesar de ter seguido o voto do Relator e deferido a segurança apenas parcialmente (mantendo o acréscimo pessoal de $20 \%$ sobre os proventos, mas até que seu montante seja absorvido pelo subsídio fixado em lei para o Ministro do STF, sob o fundamento da irredutibilidade de vencimentos), fez questão de registrar a questão da proibição do retrocesso social, ao destacar o impedimento de se desconstituir conquistas já alcançadas pelo cidadão, "que não pode ser

\footnotetext{
254 Supremo Tribunal Federal. Ação Direta de Inconstitucionalidade $n^{\circ}$ 3.105/DF. Relatora Ministra Ellen Gracie. Ementa publicada no Diário da Justiça em 18 de fevereiro de 2005. Disponível em $<$ http://www.stf.gov.br > . Acesso em 20 de janeiro de 2012.

${ }^{255}$ Supremo Tribunal Federal. Mandado de Segurança $n^{\circ}$ 24.871/DF. Relator Ministro Sepúlveda Pertence. Ementa publicada no Diário da Justiça em 06 de outubro de 2006. Disponível em <http://www.stf.gov.br $>$. Acesso em 20 de janeiro de 2012.

256 "Conserte-se o Brasil - com "s" e com "c" -, mas sem retrocesso cultural, sem retroação, sem gerar-se, quanto a situações jurídicas aperfeiçoadas, porque surgidas sob a égide de certo arcabouço normativo, insegurança, o sentimento de não saber o que poderá ser o amanhã, tendo em vista o que alcançado, anteriormente - repito - em harmonia com a ordem jurídica em vigor." Disponível em $<$ http://www.stf.gov.br $>$. Acesso em 20 de janeiro de 2012.
} 
despojado, por isso mesmo, em matéria de direitos sociais, no plano das liberdades reais, dos níveis positivos de concretização por ele já atingidos." 257

Em outro julgamento de Ação Direta de Inconstitucionalidade $n^{\circ} 3.104 / \mathrm{DF}^{258}$, que buscava a inconstitucionalidade dos $\operatorname{artigos} 2^{\circ}$ e da expressão $8^{\circ}$ do artigo 10 , ambos da Emenda Constitucional 41/2003, em razão da alteração dos critérios de transição anteriormente propostos para fins de aposentadoria no regime próprio de previdência social, a questão do retrocesso social foi novamente suscitada, porém, com maior enfoque na questão da segurança jurídica, a exemplo do defendido por Ingo Sarlet, acima revisitado.

Os votos vencidos dos Ministros Carlos Britto e Marco Aurélio de Mello, que julgaram pela procedência da ação, vislumbraram a questão da proibição do retrocesso social, como forma de proteger os direitos fundamentais sociais e, também a questão da segurança jurídica das relações, em especial previdenciárias, cujas constantes alterações têm sido inesgotável fonte de retrocesso. Assim, no dizer do Ministro Carlos Britto:

Não me parece lógico, até porque um dos sentidos das cláusulas pétreas é impedir o retrocesso. É garantir o avanço. Esse o significado último de uma cláusula pétrea. A nova Constituição traz uma conquista política, social, econômica e fraternal, de que natureza for, e a petrealidade passa a operar como uma garantia do avanço, então obtido. Uma interdição ao retrocesso.

No que é complementado pelo Ministro Marco Aurélio de Mello:

Digo que não é regra alterar uma cláusula de transição via idêntica medida, pelo menos para que se possa cogitar de um mínimo de segurança jurídica e o Estado está organizado para proporcionar aos cidadãos segurança jurídica. Não é aconselhável a mudança de uma cláusula de transição.

Será que o sacrifício de um valor maior que é a estabilidade, a segurança jurídica, será que mediante o sacrifício dos servidores públicos, bodes expiatórios, haverá a solução da Previdência Social? Será que com o sacrifício de um valor básico - e paga-se um preço por se viver em uma

\footnotetext{
${ }^{257}$ Destaque-se ainda a seguinte passagem do voto proferido pelo Ministro Celso de Mello: "Na realidade, a cláusula que proíbe o retrocesso em matéria social traduz, no processo de sua concretização, verdadeira dimensão negativa pertinente aos direitos sociais de natureza prestacional, impedindo, em consequência, que os níveis de concretização dessas prerrogativas, uma vez atingidos, venham a ser reduzidos ou suprimidos, exceto nas hipóteses - de todo incorrente na espécie - em que políticas compensatórias venham a ser implementadas pelas instâncias governamentais." Disponível em $<$ http://www.stf.gov.br $>$. Acesso em 20 de janeiro de 2012.

${ }^{258}$ Supremo Tribunal Federal. Ação Direta de Inconstitucionalidade ${ }^{\circ}$ 3.105/DF. Relatora Ministra Carmen Lúcia. Ementa publicada no Diário da Justiça em 09 de novembro de 2007. Disponível em $<$ http://www.stf.gov.br $>$. Acesso em 20 de janeiro de 2012.
} 
democracia, e ele é módico, ao alcance de todos -, o respeito às regras estabelecidas, ter-se-á a salvação da Previdência?

Recentemente, outras decisões ${ }^{259}$ proferidas pelo Pretório Excelso concernentes à matéria de direitos fundamentais têm-se utilizado do princípio da proibição do retrocesso social como fundamento balizador na defesa de tais direitos. Isso demonstra que a questão do retrocesso social, apesar de seu tímido início, vem ganhando cada vez mais espaço nas decisões das Cortes brasileiras, na busca por uma garantia total e irrestrita dos direitos sociais. Para além disso, faz-se

necessário, contudo, avançar em estratégias de litigância no âmbito nacional, que otimizem a justiciabilidade e a exigibilidade dos direitos econômicos e sociais, como verdadeiros direitos públicos subjetivos, por meio do empowerment da sociedade civil e de seu ativo e criativo protagonismo.

Há que se reinventar a relação com o Poder Judiciário, ampliando seus interlocutores e alargando o universo de demandas, para converter esse Poder em um locus de afirmação de direitos, que dignifique a racionalidade emancipatória dos direitos sociais e econômicos como direitos humanos nacional e internacionalmente garantidos. ${ }^{260}$

\subsection{Da aplicação do retrocesso social diante da globalização econômica}

É certo afirmar que a construção do constitucionalismo fundou-se às custas do surgimento de uma sociedade burguesa, que demandou a instituição de um mecanismo de organização do exercício do poder político e de proteção de direitos individuais dentro de um sistema anteriormente concebido de limitação de direitos e poderes.

Assim, observa-se que o constitucionalismo nasceu e teve sua primeira fase de desenvolvimento baseado em ideias de individualismo, intervenção estatal mínima e liberalismo econômico que sustentou o modo capitalista de produção, em especial após a Revolução Industrial.

A fúria do avanço capitalista observada em consequência da Revolução Industrial teve como principal efeito a exploração desenfreada do trabalho humano, realizado em condições

\footnotetext{
${ }^{259}$ ADC 29/DF - Relator Ministro Luiz Fux; ADC 30/DF - Relator Ministro Luiz Fux; ADI 4578/AC - Relator Ministro Luiz Fux; ARE 639337 AgR/SP - Relator Ministro Celso de Mello; RE 251750/RJ - Relator Ministro Marco Aurélio de Mello.

${ }^{260}$ PIOVESAN, Flávia. Justiciabilidade dos direitos sociais e econômicos: desafios e perspectivas. Direitos Fundamentais Sociais. Org. José Joaquim Gomes Canotilho, Marcus Orione Gonçalves Correia e Érica Paula Barcha Correia. São Paulo: Saraiva, 2010. p. 69.
} 
indignas e sub humanas, a fim de suportar o crescimento econômico da classe burguesa emergente.

O resultado desse colapso das relações de trabalho, pautado pela coisificação da vida humana, gerou a necessidade de uma postura ativo-protetiva do Estado, em detrimento do absenteísmo anterior. Denota-se, então, o surgimento de um Estado intervencionista, voltado para a proteção dos indivíduos, para o reconhecimento dos direitos sociais e para a busca da garantia de condições mínimas de sobrevivência. É o Estado de Bem Estar Social (Welfare State), cuja Constituição, além de se ocupar em organizar o exercício do poder político e estabelecer direitos fundamentais, ainda tem como função planejar programas de ação a serem perseguidos pelo Estado. ${ }^{261}$

O constitucionalismo, portanto, ressurgiu com um caráter dirigente e suportado por conceitos de nação, Estado e soberania, além dos princípios de legalidade, hierarquia das leis e segurança jurídica. ${ }^{262}$

Durante muito tempo, essa formatação de constitucionalismo permaneceu vigente, abarcando novas facetas de direitos fundamentais e novos princípios, como o da própria proibição do retrocesso social, temática de abrangência deste estudo. Porém, a busca pelo crescimento e desenvolvimento econômico iniciou um movimento progressivo de desregulamentação financeira, o qual promoveu a quebra das barreiras nacionais dos Estados de forma a garantir a expansão dos mercados (capitalismo) e a homogeneização das práticas comerciais e financeiras.

Esse movimento, conhecido como globalização, desenhado a partir do desenvolvimento das tecnologias e das comunicações, ramificou seus efeitos para além do aspecto econômico, atingindo a interligação social, cultural e até política. Dentro dessa perspectiva, a organização política e jurídica do Estado sofre considerável abalo, principalmente no que concerne à consequente relativização da soberania estatal. ${ }^{263}$

\footnotetext{
${ }^{261}$ DERBLI, op. cit., p. 19.

${ }^{262}$ Ibid., p. 20.

${ }^{263}$ DERBLI, op. cit., p. 21.
} 
concebidas para a disciplina de relações unidimensionais; o Estado se revela cada vez mais impotente para interferir nas relações socioeconômicas, agora fixadas em bases geográficas que transcendem os limites territoriais aos quais se circunscreve o poder estatal; os paradigmas do Direito vão sofrendo contínua erosão, tornando-se insuficientes para trabalhar as novas categorias de relações mundiais. ${ }^{264}$

O Estado sofre, nessa medida, uma restrição em sua margem de atuação, principalmente no que concerne à proteção social, a partir do entendimento de que o capital internacional e os meios de produção passam a reger as regras de desenvolvimento econômico, fazendo com que os grupos econômicos transacionais, orientados para a busca do maior lucro possível, façam uso de sua internacionalidade para não mais estarem sujeitos a normas que não lhes sejam favoráveis.

A consequência imediata dessa nova postura decorrente da globalização é a tentativa de flexibilização do direito interno por países em busca do crescimento econômico, inclusive com a modificação de suas Constituições, para atrair investimentos, a partir da promessa de garantia de legislação propícia ao incremento dos lucros. ${ }^{265}$

Diante da problemática ora verificada, como se aplicar um princípio de proibição de retrocesso social, quando as barreiras legais deixam de existir em função de um crescimento econômico globalizado? Quando a soberania estatal passa a se curvar diante das exigências do mercado capitalista? Quando as empresas exigem redução na proteção social para garantia de um aumento na lucratividade? Quando relações sociais deixam ser nacionais para se tornarem supranacionais, envolvendo Estados com diferentes perspectivas?

Em que pese o Brasil ser um país com uma Constituição eminentemente dirigente, voltada para proteção social através da prévia definição dos fins públicos, observa-se a tentativa de flexibilização de alguns direitos sociais com vistas a adequar o país às novas regras trazidas pelo mundo globalizado.

A tentativa de limitação de direitos sociais, no entanto, sempre encontrou óbice em barreiras principiológicas de proteção, como é o caso da proibição de retrocesso, cuja

${ }^{264}$ DERBLI, op. cit., p. 20.

265 "Portanto, o domínio da lex mercatoria retira do Estado a exclusividade da normatização, passando a predominar os usos do comércio internacional, os contratos de adesão, as regulamentações profissionais elaboradas por suas entidades representativas e os princípios gerais comuns às legislações dos diversos países." (Ibid., p. 24). 
fundamentação decorre da natureza intervencionista e hegemônica da Constituição Federal de 1988.

Diante do enfraquecimento da soberania estatal, é comumente dito que as Constituições intervencionistas, incluindo a brasileira, não tiveram alternativa senão se adaptar à nova sistemática, o que atingiu diretamente a proteção social duramente conquistada.

Contudo, essa solução não nos parece a mais adequada ou sequer imprescindível para a manutenção da competitividade e do crescimento econômico. A resposta está na defesa da dignidade da pessoa humana acima de qualquer causa ou circunstância, fato já consagrado no entendimento da atual sociedade contemporânea. E com o reconhecimento da necessidade premente e inviolável da defesa da dignidade humana, princípios como o da proibição do retrocesso social encontram abertura de aplicabilidade mesmo dentro de uma mentalidade eminentemente voltada para a redução dos custos de produção para aumento do lucro.

Dentro do ordenamento jurídico interno de um Estado, ainda que em um mundo globalizado, a proibição do retrocesso social encontra respaldo na própria garantia aos direitos fundamentais existentes em função da proteção à dignidade da pessoa humana, decorrente de um constitucionalismo social que ainda apresenta vestígios, principalmente em razão da universalização dos direitos humanos.

Assim, a tentativa de flexibilização de direitos fundamentais sociais encontra óbice na necessidade de manutenção do núcleo essencial de tais direitos, que não é passível de qualquer redução ou limitação.

Portanto, mesmo com um novo perfil de constitucionalismo neoliberalista, com o retorno ao Estado mínimo e a promoção da redução das normas programáticas, as Constituições atuais, ainda que tendentes a flexibilizar direitos, permanecem fundadas nos princípios da soberania popular e da democracia, o que, em razão do poder originário da sociedade e da consagração histórica dos direitos fundamentais, cria entraves à afetação do núcleo essencial desses direitos. E é essa impossibilidade de afetação dos direitos fundamentais o que justamente embasa a proibição de retrocesso social e justifica a sua aplicabilidade. 
Observa-se, pois, que a participação do Estado ainda é imprescindível para a garantia das reduções das desigualdades sociais e a da garantia de vida em uma sociedade digna e justa.

Nesse mister, é imperioso reconhecer a força normativa da Constituição, capaz de operar na sociedade as mudanças por ela desejadas. Por mais sensíveis que tenham sido os abalos causados sobre os paradigmas de Direito Constitucional pelo fenômeno da globalização, não se pode ser ignorada toda uma bem sucedida evolução do constitucionalismo, interrompendo-se o projeto de modernidade cuja implementação tanto custou a iniciar. ${ }^{266}$

Nessa medida, o caráter dirigente da Constituição encontra subsídios para se manter, reforçando a legitimidade do exercício democrático do poder público.

Por outro lado, considerando o aspecto supranacional, a proibição do retrocesso social ainda encontra razões para se manter ativa, nada obstante os avanços de uma economia globalizada.

Mesmo que se admita que o constitucionalismo contemporâneo, baseado em premissas dirigentes e normas programáticas, tenha restado ultrapassado pela progressivo e irrefreável crescimento da economia globalizada, ainda é possível identificar blocos internacionais de proteção universalizada dos direitos humanos, aí incluídos os direitos sociais, cujo objetivo final é sempre a garantia da dignidade da pessoa humana.

Desde o fim da Segunda Guerra Mundial, tem-se desenvolvido ao redor do mundo a necessidade de uma proteção universalizada aos direitos humanos, de forma a garantir que sejam observados em qualquer parte do globo. Assim, a comunidade internacional unificou-se para a criação de um sistema de tutela dos direitos fundamentais em escala mundial, justificada pelo fato de que questões de tal importância não podem ser deixadas apenas sob a tutela dos Estados. Mesmo porque, na maioria das vezes, são os próprios Estados os maiores agressores desses direitos. ${ }^{267}$

Portanto, a proteção conferida pelos Estados foi deslocada para os grandes órgãos internacionais, tais como a Organização das Nações Unidas e a Organização Internacional do

\footnotetext{
${ }^{266}$ DERBLI, op. cit., p. 41.

${ }^{267}$ Ibid., p. 25.
} 
Trabalho, cujos tratados, declarações, cartas, orientações e demais documentos são provenientes de um entendimento consubstanciado na proteção à dignidade da pessoa humana a partir do reconhecimento e exigibilidade de direitos fundamentais.

Vale ressaltar, inclusive, que os direitos fundamentais reconhecidos em documentos internacionais de proteção aos direitos humanos também serviram de base para a construção de Constituições ao redor do mundo, sendo muitas vezes recepcionado pelo direito interno dos Estados como norma de caráter constitucional, como é o caso do Brasil.

Nessa medida, se considerarmos a fundamentalidade desses direitos internacionalmente reconhecidos, protegidos e garantidos, torna-se ponto comum o entendimento de que tais direitos também possuem um núcleo essencial intangível. Consequentemente, qualquer ofensa a esse núcleo intocável atingiria diretamente a dignidade humana, promovendo retrocesso social.

Presente, pois, a concepção de proibição de retrocesso social na esfera supranacional como última barreira de proteção aos direitos humanos sociais fundamentais.

A única falha nessa modalidade de sistema é a ausência de condutas coercitivas para a obrigatoriedade do cumprimento das decisões proferidas pelos órgãos internacionais. Nada obstante a criação de Tribunais Internacionais para correção dessa questão, ainda se faz necessário dotar tais Tribunais de necessária autoridade para coibir atos atentatórios à dignidade humana.

De qualquer modo, deve-se ter sempre em mente que a dignidade humana jamais pode ser atingida, não importa o quanto seja necessário o crescimento e o desenvolvimento econômico de um Estado e a sua posição dentro de um mundo globalizado. E é justamente essa percepção, já enraizada na sociedade mundial, que garante a aplicação do princípio da proibição do retrocesso social para certificar um mínimo de proteção social aos indivíduos. 


\section{DIREITOS HUMANOS SOCIAIS: DO DIREITO À PREVIDÊNCIA SOCIAL}

\subsection{Breve notícia histórica}

A Seguridade Social (assistência social, previdência social e saúde) teve seu início a partir de uma noção de indigência, embasando a motivação de atitudes por parte da humanidade com o objetivo de combater esse mal social, no qual as pessoas não possuem condições de satisfazer suas necessidades mais básicas de sobrevivência. Nesse sentido, a indigência traduz-se em um fenômeno de exclusão social, presente desde os primórdios das civilizações e que, desde então, vem sendo objeto de iniciativas na tentativa de acabar com essa questão social séria. ${ }^{268}$

Desde a Antiguidade, denota-se a existência de preocupação quanto a contingências futuras. Muito embora nesse período histórico o indivíduo fosse apenas um objeto de poder, estando vinculado às leis ditadas por divindades, denotam-se agrupamentos profissionais no antigo oriente e nos colégios gregos e romanos. E essas instituições, principalmente os Collegia romanos possuíam natureza mutualista, na medida em que, além de finalidades religiosas e econômicas, mantinham um regime de ajuda recíproca entre seus membros. Esses Collegia existiram até a queda do Império Romano. ${ }^{269}$

Já na Idade Média, caracterizada pelo regime feudal, também podem ser encontrados antecedentes da noção de Seguridade Social, principalmente após o surgimento da burguesia, que alavancada pela noção de individualismo, promoveu o progresso da indústria e a expansão do comércio, ocasionando uma revolução mercantil.

Surgem nesse período as associações e as guildas (de características religiosas), através da noção de assistência em caso de pobreza, velhice ou doença, que consolidaram um reflexo natural da associação dos homens livres que buscavam a defesa de interesses comuns e cuja evolução notável terá consequências profundas na construção de um novo tipo de sociedade. ${ }^{270}$

\footnotetext{
${ }^{268}$ FERREIRA, op. cit., p. 92.

${ }^{269}$ ROCHA, op. cit., p. 21.

${ }^{270}$ Ibid., p. 23.
} 
Na Idade Moderna, surgida com o Renascimento e seu pensamento liberal, trouxe a noção de indivíduo como sujeito de direitos. E dentre esses direitos, havia a proteção das necessidades sociais. Nesse período histórico, a Inglaterra destacou-se como o país no qual a instituição da assistência do Estado aos pobres atingiu um desenvolvimento mais amplo e característico, a exemplo do Poor Relief Act (Lei de Amparo aos Pobres), cujo objetivo era a assistência paroquial aos pobres.

A Idade Contemporânea surge com o advento das declarações de direito, proferidas na América (1776) e na França (1789), que converteram direitos naturais em direitos constitucionais dotados de valor jurídico. A Revolução Francesa trouxe a Declaração Universal dos Direitos do Homem e do Cidadão, que alavancou a noção de justiça social, com a busca por melhores condições de vida como pressuposto da dignidade da pessoa humana.

A Revolução Francesa, marco da ascensão da burguesia ao poder, também promoveu a implementação de um Estado Liberal, cujo princípio adotado foi o da intervenção mínima, no qual as crises sociais deveriam ser resolvidas pela própria sociedade, sem a interferência estatal, em respeito à sua autonomia. Com isso, a proteção social inicialmente prevista pela Declaração Universal foi relegada a segundo plano.

A busca pelo crescimento econômico promovida pela burguesia fez surgir a Revolução Industrial, que criou um desenvolvimento econômico sem precedentes. Contudo, apenas uma pequena parcela da sociedade foi favorecida por este crescimento. Os demais, trabalhadores em sua maioria, sofreram um brutal regime de exploração, com consequentes riscos no exercício da atividade laborativa, principalmente, em decorrência da utilização de maquinário industrial.

Por outro lado, a busca por melhores condições de vida fez com que a população do campo migrasse para a cidade, promovendo uma crescente concentração populacional nos centros urbanos, que, por sua vez, não dispunham de infraestrutura adequada para suportar a demanda de pessoas.

Tais problemas embasaram a formação de um Estado Social de Direito, no qual se impunha a necessidade de uma postura empreendedora do Estado para implementação dos direitos sociais, com o fim de restabelecer um equilíbrio mínimo nas relações sociais. 
Em 1883, Otto Von Bismarck cria na Alemanha um projeto de seguro operário, com cobertura compulsória dos riscos de acidente do trabalho. Em 1889, é criado o seguro invalidez e velhice. Essa reforma tinha como objetivo impedir movimentos socialistas fortalecidos com a crise industrial.

Nessa mesma esteira de Estado Social, são promulgadas, em 1917 a Constituição do México, primeira a inserir em seu bojo normas sobre seguro social, e em 1919 a Constituição de Weimar, também apresentando direitos relativos à seguridade social.

Com a crise econômica de 1929, os Estados Unidos adotaram a política do New Deal, desenvolvida por Franklin D. Roosevelt, através da doutrina do Welfare State (Estado de Bem Estar Social), buscando estabelecer um conjunto de políticas estatais para criar novos empregos e uma rede de previdência e saúde públicas. Em decorrência dessa decisão, em 1935 surge o Social Security Act, que empregou pela primeira vez a expressão "seguridade social", assumindo o Estado a responsabilidade por toda a segurança social, com objetivo de defender e impulsionar o desenvolvimento de toda a população e não apenas dos trabalhadores.

Em 1941, o economista inglês Sir William Beveridge realiza um estudo sobre a seguridade social na Inglaterra. O resultado dessa análise é denominado Plano Beveridge, que unificou as ideias de busca da erradicação de todas as necessidades do homem (de Roosevelt) e de distribuição de renda mais igualitária (de Keynes), criando um sistema de segurança a ser prestado do berço ao túmulo, isto é, englobando as contingências da vida: nascimento, doença, velhice, morte.

Os efeitos devastadores da $2^{\mathrm{a}}$ Guerra Mundial contribuíram para a formação dos Estados de Bem Estar Social, embasados pela Declaração dos Direitos Universais do Homem promovida pela Organização das Nações Unidas (ONU) em 1948, no qual a proteção previdenciária insere-se como um dos direitos fundamentais da pessoa humana. ${ }^{271}$

\footnotetext{
${ }^{271}$ Art. 25: $\$ 1$. Toda pessoa tem direito a um padrão de vida capaz de assegurar a si e a sua família saúde e bemestar, inclusive alimentação, vestuário, habitação, cuidados médicos e os serviços sociais indispensáveis, e direito à segurança em caso de desemprego, doença, invalidez, viuvez, velhice ou outros casos de perda dos meios de subsistência em circunstâncias fora de seu controle. §2. A maternidade e a infância têm direito a
} 
No Brasil, o desenvolvimento não foi caracterizado pela transição do feudalismo para o capitalismo moderno, com um mínimo de intervenção social. Por sua situação de colônia até praticamente a primeira revolução industrial (1820/1830), antes mesmo de ingressar na era industrial, o Brasil já apresentava contornos marcados por desigualdades, principalmente em razão de má (ou inexistente) distribuição de renda. ${ }^{272}$

Deste modo, todas as oito constituições brasileiras buscaram a proteção social através da expressão do ideário de cada época. A Constituição de 1824, outorgada durante a transição de colônia para monarquia institucional refletiu os interesses dos grandes latifundiários escravocratas, apenas prevendo a garantia a socorros públicos. Mais tarde, ainda sob a sua égide, alguns decretos foram editados criando alguns fundos de proteção de determinadas classes de trabalhadores. Os principais instrumentos de proteção social eram a beneficência e a assistência pública.

Somente com a Constituição de 1891 verifica-se a primeira referência a um benefício previdenciário típico: aposentadoria para funcionários públicos. Sob sua égide, surgiu a primeira norma a instituir a previdência social: Lei Eloy Chaves (Decreto $n^{\circ} 4682$, de 24 de janeiro de 1923), com a criação das Caixas de Aposentadorias e Pensões para ferroviários, em nível nacional. Foi a partir da Lei Eloy Chaves que a administração colegiada dos gestores da caixa passou a contar com representantes do governo, das empresas e dos empregados.

O período entre 1931 e 1959 concentra o surgimento dos grandes institutos de aposentadoria e pensões, de âmbito nacional e por categoria profissional, até porque o sistema introduzido pela Lei Eloy Chaves, por empresa, não foi suficiente para proteger todos os trabalhadores.

A Constituição de 1934 sofreu influência direta da Constituição mexicana de 1917 e da Constituição de Weimar de 1919, razão pela qual teve importância fundamental no reconhecimento da proteção dos direitos sociais no Brasil, que também foram reafirmados pela Constituição de 1946.

cuidados e assistência especiais. Todas as crianças, nascidas dentro ou fora de matrimônio, gozarão da mesma proteção social.

${ }^{272}$ ROCHA, op. cit., p. 45. 
Com a criação da LOPS - Lei Orgânica da Previdência Social (Lei no 3807/1960), o sistema previdenciário brasileiro começou a buscar uma organização efetiva. O sistema por ela criado abrangia todos que exercessem atividade remunerada no território nacional, exceto os trabalhadores rurais, funcionários públicos e militares, além dos empregados domésticos, que mantinham seus próprios regimes.

Em 1966 foi criado o Instituto Nacional de Previdência Social - INPS, que unificou todas as caixas e institutos de aposentadorias e pensões existentes. Nessa fase, existiu uma preocupação especial do governo brasileiro com a área previdenciária, principalmente em função da Revolução de 1964, na qual entendeu-se que a má distribuição dos serviços previdenciários gerava insatisfação das massas, ocasionando tensões sociais prejudiciais à segurança nacional.

A Constituição Federal de 1988 restabeleceu a ordem democrática no país, assegurando o exercício dos direitos sociais e individuais, com vistas à preservação da dignidade da pessoa humana. A seguridade social é concebida como gênero de técnicas de proteção social.

Diante da nova política econômica dos anos 90, com a abertura comercial, a privatização das empresas e atividades exercidas pelo Estado, além da desregulamentação das relações econômicas e de trabalho, houve um déficit significativo no sistema previdenciário, que necessitava de urgente reforma. A Emenda Constitucional $n^{\circ}$ 20/1998 foi editada em um cenário desfavorável, apresentando um caráter eminentemente restritivo. ${ }^{273}$ Suas alterações propostas tinham como princípio basilar o aumento da arrecadação a fim de burlar o déficit apresentado, através de implementação de maiores requisitos para obtenção de benefícios, além da manutenção do segurado por mais tempo no regime, ampliando a contribuição.

Em 2003, a Emenda Constitucional $n^{0}$ 41/2003 estabeleceu alterações também no regime próprio previdenciário dos servidores públicos, com o objetivo de diminuir os custos e nivelar por baixo a previdência mantida pelo Estado, de forma a permitir a introdução de um

${ }^{273}$ ROCHA, op. cit., p. 76. 
pilar obrigatório de previdência privada, o qual deveria permitir o aumento da capacidade de poupança interna para viabilizar a aceleração do desenvolvimento econômico.

E é dentro desse contexto que se insere a necessidade e a importância da aplicação do princípio da proibição do retrocesso social. Pelas constantes mudanças trazidas por Emendas Constitucionais, se torna imprescindível a análise da afetação do núcleo essencial de cada direito fundamental social voltado à seguridade social em geral e à previdência social em particular, a fim de se determinar se essas medidas estão sendo realizadas à luz da garantia da dignidade da pessoa humana.

\subsection{Do direito fundamental à Previdência Social}

A existência humana comporta uma série de acontecimentos que, diante de sua imprevisibilidade, podem impedir a satisfação das necessidades básicas do ser humano na busca por uma vida digna. Tais acontecimentos, como a doença, a invalidez, a velhice, o desemprego, a morte, são denominados contingências sociais.

Nesse sentido, uma concepção de previdência social deve partir, necessariamente, da ideia de proteção contra essas contingências sociais, que provocam as necessidades sociais.

Consideram-se contingências sociais eventos futuros e incertos que podem ocorrer na vida de um indivíduo de forma a diminuir ou a suprimir sua capacidade de manutenção de sua subsistência e de sua família, como a doença, a morte, a invalidez, a velhice, o desemprego. Nesse conjunto também podem ser incluídos fatos que acarretem maiores encargos, como por exemplo, o nascimento de filhos. Conclui-se, nessa medida, que as contingências sociais têm como elemento comum a perda da possibilidade de trabalho ou o aumento de gastos.

Observa-se, portanto, uma necessária interligação entre o interesse individual e o interesse social, na medida em que as contingências sociais não afetam apenas os indivíduos, mas repercutem na organização social, provocando desequilíbrios e problemas para toda a coletividade. ${ }^{274}$

\footnotetext{
274 VIDAL NETO, Pedro. Natureza Jurídica da Seguridade Social. Tese (Titular). Faculdade de Direito da Universidade de São Paulo. São Paulo, 1993. p. 12.
} 
Cumpre salientar que a previdência social, não obstante seu caráter protetivo, não tem finalidade indenizatória, a fim de ressarcir ou compensar dano sofrido pelo indivíduo. Ao contrário, seu objetivo é proporcionar ao indivíduo atingido por alguma contingência social meios de satisfazer suas necessidades básicas, dando-lhe um mínimo de cobertura para enfrentar os acontecimentos que o colocaram em estado de necessidade.

A finalidade, portanto, da previdência social é o bem estar social, sendo seu objetivo principal a preservação da dignidade da pessoa humana e consequentemente, a proteção dos direitos humanos.

Dentro dessa perspectiva, o direito do indivíduo à proteção social prevista por um sistema de previdência social constitui-se em um valor. E, para haver a respectiva observância e consequente exigência, esse valor deve ser garantido como um direito fundamental, na medida em que tratam da satisfação das mais elementares e vitais necessidades da pessoa. ${ }^{275}$

Nesse contexto, a fruição da proteção trazida pelos regimes previdenciários é um dos mais importantes direitos fundamentais do ser humano, devendo ser garantido não só em patamar constitucional, mas também no plano institucional, a partir de

\begin{abstract}
um modelo de ação estatal, que traça as políticas de ação social tendentes à satisfação das necessidades básicas do indivíduo, mas é também um padrão de comportamento da própria sociedade organizada. Constitui-se também num espaço vital que liga o ser humano com outro ser humano e com a sociedade, num processo de solidariedade que lhe é típico e necessário ao próprio funcionamento. E é, por último, um regime ou plano de ação, de objetivos e fins estruturado de forma sistêmica, tornando-se o arcabouço de um processo de socialização e estabilização do comportamento social. ${ }^{276}$
\end{abstract}

Assim sendo, ao também se enquadrar na condição de instituição, deve a previdência social postar-se de forma alheia a questões não relacionadas ao seu mister, qual seja, garantia da dignidade humana, sendo preservada como sistema de proteção social e de redistribuição de renda.

\footnotetext{
${ }^{275}$ SIMM, Zeno. Os Direitos Fundamentais e a Seguridade Social. São Paulo: LTr, 2005. p. 115.

${ }^{276}$ SIMM, op. cit., p. 116-117. (grifos no original)
} 
Com base nessa análise, o direito à previdência social apresenta um núcleo essencial inafastável e intocável, o qual não pode ser objeto de restrição ou extinção, sob pena de se configurar retrocesso social.

E o núcleo essencial do direito à previdência social pode ser verificado por meio dos próprios eventos listados pela Constituição brasileira nos incisos de seu artigo 201, assim considerados pelo legislador constitucional originário como relevantes circunstâncias que podem afetar negativamente o desenvolvimento do homem de tal modo a ponto de atingir sua dignidade.

Portanto, situações como morte, doença, invalidez, velhice, maternidade, desemprego, reclusão e formação de família, para além da proteção da cláusula pétrea, formaram o foco da atenção e objeto de escolha da Constituição para a garantia previdenciária com vistas à justiça social e dignidade da pessoa humana.

Nessa medida, a eliminação dessas contingências ou a ausência de prestações previdenciárias que garantam a plena eficácia e eficiência da proteção contra tais situações atinge frontalmente o núcleo essencial do direito à previdência social. Nessas hipóteses, a ofensa ao princípio da proibição do retrocesso social é cristalina e indiscutível.

\subsubsection{Direito comparado}

Por se tratar de um direito fundamental social, conquistado a partir da necessidade humana pela busca da dignidade, a previdência social tem previsão em vários outros ordenamentos jurídicos pelo mundo.

Nada obstante a já consagrada importância para o desenvolvimento social do homem, a garantia de uma previdência social em vários ordenamentos jurídicos traduz-se hoje na garantia desse direito fundamental em um mundo globalizado, na medida em que tratados internacionais e acordos entre países preveem a possibilidade de reciprocidade na percepção desse direito.

A Declaração Universal dos Direitos Humanos da Organização da Nações Unidas já estabelecia desde 1948 a necessidade de garantia de uma segurança social, de forma garantir a 
observância de direitos sociais indispensáveis ao alcance da dignidade humana. ${ }^{277}$ Nessa mesma esteira, o Pacto Internacional dos Direitos Econômicos, Sociais e Culturais, de 1966, estabeleceu expressamente o direito à previdência social, a ser garantido pelos países signatários. $^{278}$

Ainda sobre o tema, a Convenção 102 da Organização Internacional do Trabalho, de 1955, estabeleceu padrões mínimos relativos à seguridade social, de forma a garantir a observância e a proteção a esse direito fundamental. ${ }^{279}$

Ratificada pelo Brasil em 25 de setembro de 1992, a Convenção Americana de Direitos Humanos (Pacto de San Jose da Costa Rica, de 22 de novembro de 1969), além de estabelecer a necessidade de um desenvolvimento progressivo para a efetividade plena dos direitos decorrentes de normas econômicas, sociais, de educação, ciência e cultura, ainda assegura o desenvolvimento de uma política eficiente de previdência social (artigo 45, h). ${ }^{280}$

A vigência dos tratados de direitos humanos reclama algumas regras especiais, justamente por tratarem de matéria de relevante interesse para a sociedade internacional. Desta feita, tornam-se obrigatórios para todos os que ratificarem os tratados internacionais de direitos humanos, gerando responsabilidade internacional em caso de não cumprimento. Ademais, os pactos de direitos humanos exigem, além da observância dos princípios e regras nele estabelecidos, o comprometimento dos Estados dele signatários de adotar medidas necessárias para assegurar o seu pleno exercício.

Em atenção às normas supra mencionadas, Brasil, Argentina, Cuba, Chile e Uruguai foram pioneiros na formação de sistemas de pensões na América Latina. Esses países

\footnotetext{
${ }^{277}$ Artigo XXII: Todo ser humano, como membro da sociedade, tem direito à segurança social, à realização pelo esforço nacional, pela cooperação internacional e de acordo com a organização e recursos de cada Estado, dos direitos econômicos, sociais e culturais indispensáveis à sua dignidade e ao livre desenvolvimento da sua personalidade.

${ }^{278}$ Artigo 9 $9^{\circ}$ : Os Estados Membros no presente Pacto reconhecem o direito de toda pessoa à previdência social, inclusive ao seguro social.

${ }^{279}$ Ratificada pelo Brasil em 15 de junho de 2009.

${ }^{280}$ SAVARIS, José Antonio. Traços Elementares do Sistema Constitucional de Seguridade Social. Curso de Especialização em Direito Previdenciário. Org. Daniel Machado da Rocha e José Antonio Savaris. vol. 1. $1^{\mathrm{a}}$ ed., $2^{\text {a }}$ tir. Curitiba: Juruá, 2006. p. 124.
} 
organizaram seus sistemas a partir de um regime de capitalização coletiva, que, posteriormente, acabou sendo modificado para um regime de repartição. ${ }^{281}$

Os sistemas previdenciários latino-americanos foram resultado de um processo conjunto de pressão por proteção social de um lado, e de atração dos grupos de interesse por meio de ações populistas pelo Estado provedor dos benefícios sociais, de outro. Assim, os Estados iniciaram a formação de um conjunto de benefícios, de cunho previdenciário, a ser direcionado, inicialmente, à classe trabalhadora, e, posteriormente, promovendo a expansão seletiva dos programas. Além disso, o Estado acabou por assumir a responsabilidade pela administração do custeio e da concessão dos benefícios, especialmente em países como o Brasil e a Argentina. ${ }^{282}$

O reflexo futuro dessa preocupação transpareceu na própria formação do Mercosul (Mercado Comum do $\mathrm{Sul}^{283}$ ). Nada obstante ter sido concebido com objetivos comerciais, a integração trazida envolveu aspectos sociais (de cunho trabalhista e de seguridade social), na medida em que admitiu-se o trânsito irrestrito de pessoas entre os países participantes.

Assim, a Declaração Sociolaboral do Mercosul $^{284}$, apesar de não estabelecer leis sociais, teve como objetivo promover direitos sociais para os cidadãos dos países pertencentes ao bloco econômico então formado, corroborando o entendimento de que os direitos sociais são fundamentais para o alcance da dignidade e do desenvolvimento humano, a exemplo do já profetizado pela Organização das Nações Unidas e pela Organização Internacional do Trabalho.

Também na Europa, a criação da União Europeia teve como objetivo a promoção da unidade de seus membros com o fim de proteger e instituir o progresso econômico e social,

\footnotetext{
${ }^{281}$ HORVATH JUNIOR, Miguel. Previdência Social em face da Globalização. São Paulo: Quartier Latin, 2006. p. 65.

${ }^{282}$ SILVA, Sidney Jard da. Novos Modelos Previdenciários na América Latina: lições da experiência argentina. Revista de Economia Política. vol. 28. n. 2. São Paulo: Centro de Economia Política, junho 2008. p. 315-316.

${ }^{283}$ Bloco econômico criado pelo Tratado de Assunção, em 26 de março de 1991, com vistas ao desenvolvimento de um mercado regional envolvendo países como Argentina, Brasil, Paraguai, Uruguai, Chile, Bolívia, Peru, Colômbia e Equador (esses cinco últimos como Estados associados).

${ }^{284}$ Aprovada em 10.12.1998 na cidade do Rio de Janeiro, pelos Presidentes dos quatro países membros originais (Argentina, Brasil, Paraguai e Uruguai) divide seu texto: direitos individuais (do trabalhador e do empregador), direitos coletivos, política social e disposições de aplicação e seguimento através de uma Comissão sócio-laboral de composição tripartite. (MANSUELI, Hugo Roberto. Derechos Sociales en El Mercosur. Direito Previdenciário em Debate. Coord. Instituto Brasileiro de Direito Previdenciário. Curitiba: Juruá, 2007. p. 24-25).
} 
por meio do estabelecimento de padrões mínimos de segurança social ${ }^{285286287}$ para todos os países membros, com o acompanhamento constante da evolução deste domínio.

Para tanto, o Conselho da Europa estabeleceu, por meio do Código Europeu de Segurança Social (CETS $n^{\circ}$ 048) e seu respectivo Protocolo, normas de segurança social baseadas em uma harmonização mínima do nível de segurança social, com a adoção de normas mínimas e a possibilidade de os estados membros ultrapassarem esses padrões, alterando a quantidade de benefício ou até a duração do tempo de qualificação. A ideia é justamente promover um modelo de seguridade social com vistas à justiça social por meio do estabelecimento de metas a serem alcançadas pelos estados-membros, deixando a seu cargo a determinação da forma de alcance das mesmas.

Para garantia da observância dos standards mínimos protetivos estabelecidos pelo Código Europeu de Segurança Social, um procedimento de fiscalização exige que os estadosmembros reportem sua conformidade com as normas previstas no Código. O não cumprimento gera a determinação para regularização da situação em atenção às obrigações internacionais assumidas.

Ainda, a Convenção Europeia para a Segurança Social (CETS n 078), aplicada a todos os regimes gerais de seguridade social, contributivos ou não, à luz do estabelecido pelo Código Europeu de Segurança Social, traz em seu bojo quatro princípios de coordenação internacional dos regimes nacionais de Seguridade Social: igualdade de tratamento, conjunto

\footnotetext{
285 "il principio della diretta efficacia del diritto comunitario, in base al quale le direttive, le cui disposizioni sono incondizionate e sufficientemente precise, sono immediatamente efficaci anche se lo Stato non ha provveduto, entro il tempo stabilito, a trasporre l'atto nell'ordinamento nazionale (sent. Corte UE 19-1-1982, causa 8/81)." (DEL GIUDICE, F. et alii. Compendio di Diritto dela Previdenza Sociale. I volume di base. V edizioni. Napoli: Gruppo Editoriale Esselibri - Simone, 2007. p. 31 (grifos no original)).

286 "La importancia de la Carta [Social Europea] ha sido marcar un ideal de cobertura, ya predeterminado en el Convenio n. ${ }^{\circ} 102$ OIT, sobre norma mínima de la Seguridad Social; aunque con diferencias en cuanto a los medios, a la financiación, al relieve de las pensiones públicas o privadas, al nível de cobertura de las prestaciones y al ámbito subjetivo de aplicación (Montero)." (HERNÁNDEZ, Juan Gorelli. et alii. Sistema de Seguridad Social. duodécima edición. Madrid: Editorial Tecnos, 2010. p. 39).

287 'Le 'Code' européen de sécurité sociale adopté le 16 avril 1964, a été élaboré lorsqu'il apparut que l'OIT en tiendrait à logique de la Convention 102 qui ne définit que des normes dites 'minimales'. Le Conseil de l'Europe a donc repris à son compte l'idée d'une convention sur des normes mieux adaptées au niveau de développement économique et social des nations européennes et comportant un niveau d'exigences plus élevé." (DUPEYROUX, Jean-Jacques. etalii. Droit de la sécurité sociale. $15^{\mathrm{e} e ́ d i t i o n . ~ P a r i s: ~ E ́ d i t i o n s ~ D a l l o z, ~ 2005 . ~ p . ~ 399) . ~}$
} 
único de legislação nacional aplicável, manutenção dos direitos adquiridos e em expectativa e pagamento de benefícios no exterior. ${ }^{288}$

Além das fontes de proteção realizadas por códigos e convenções internacionais, com abrangência global ou apenas ao bloco econômico respectivo, a Previdência Social também encontra respaldo em acordos bilaterais firmados entre países, que disciplinam direitos sociais a trabalhadores (permanentes ou temporários) e residentes estrangeiros, sendo-lhes aplicado o regime de previdência de cada Estado contratante. A título exemplificativo, o Brasil possui acordos internacionais de Previdência Social com países como Argentina, Cabo Verde, Espanha, Grécia, Chile, Itália, Luxemburgo, Uruguai e Portugal. ${ }^{289}$

Denota-se, portanto, que a questão da proteção social por meio de mecanismos de Previdência Social encontra respaldo em várias fontes de direito internacional, influenciando e, por vezes, direcionando o direito pátrio, de forma a consolidar o entendimento de se tratar de um direito indispensável à justiça social e ao alcance da dignidade da pessoa humana.

\subsubsection{Interpretação do Direito Previdenciário}

Para apreensão do significado de uma norma jurídica é necessário que o direito seja interpretado, de forma a lhe garantir uma dicção definitiva, porém constantemente atualizada de acordo com as necessidades crescentes da sociedade. ${ }^{290}$

Interpretar o direito significa transformar a disposição textual em norma jurídica. É extrair do conteúdo normativo sua compreensão, de modo a vislumbrar o espírito da norma. Nessa seara, interpretar o direito é concretizá-lo em cada caso, formulando uma produção prática a ser reproduzida em cada específica situação. ${ }^{291}$ A escola da subsunção, que supunha que a existência de normas prontas e acabadas para cada problema, já não mais se sustenta.

\footnotetext{
288 Informações obtidas por meio do Conselho da Europa. Disponível em $<$ http://www.coe.int/t/dg3/socialpolicies/socialsecurity/default en.asp > . Acesso em 06 de agosto de 2012.

${ }^{289}$ SAVARIS, op. cit., p. 126.

290 CORREIA, Marcus Orione Gonçalves. Interpretação do Direito da Segurança Social. Curso de Especialização em Direito Previdenciário. Org. Daniel Machado da Rocha e José Antonio Savaris. vol. 1. $1^{\mathrm{a}}$ ed., $2^{a}$ tir. Curitiba: Juruá, 2006. p. 249-250.

${ }^{291}$ GRAU, Eros Roberto. Ensaio e discurso sobre a interpretação/aplicação do direito. $4^{\text {a }}$ ed. São Paulo: Malheiros, 2006. p. xiii.
} 
A nova hermenêutica traz consigo a compreensão de que texto normativo e norma não se identificam, uma vez que esta é produzida a partir do trabalho feito pelos intérpretes com base naquele. Daí porque se diz que o direito é alográfico ${ }^{292}$, porquanto depende exclusivamente do trabalho de um intérprete.

A interpretação do direito, dentro dessa concepção, se faz, portanto, a partir da necessidade da solução de uma lide. Interpreta-se o direito com o objetivo de aplicá-lo, a partir da tomada de uma decisão jurídica em um caso concreto que se apresenta.

Nesse sentido, se a norma é extraída a partir da interpretação de textos normativos, pode-se concluir que a Constituição é formada por um conjunto de disposições normativas, que, devidamente interpretadas, passam a se expressar como normas constitucionais.

Os métodos utilizados para interpretação do direito devem levar em consideração três contextos distintos, mas igualmente importantes para o ponto de partida do processo de interpretação: o contexto linguístico, a partir da avaliação da semântica das disposições normativas; o contexto sistêmico, que considera a interpretação da lei em razão de sua posição dentro do ordenamento jurídico (sistema) e o contexto funcional, que embasa a interpretação do direito na análise da finalidade do texto normativo dentro de um contexto funcional. ${ }^{293}$

Transportando o entendimento acima desenvolvido, tem-se que a interpretação do direito previdenciário é formada a partir da textos e disposições normativos sobre a matéria.

A questão previdenciária encontra-se disposta no texto constitucional, haja vista estar intrinsecamente ligada à questão social. A Constituição brasileira de 1988 estabeleceu o direito à previdência social como um direito fundamental de cunho social, porquanto a proteção contra contingências futuras que impeçam o homem de garantir sua própria subsistência e de sua família é indispensável ao exercício de uma vida com dignidade.

\footnotetext{
292 Comparação comumente utilizada pelo Ministro Eros Grau em seus textos e palestras ao expor sobre a interpretação do direito.

${ }^{293}$ NASCIMENTO, Sérgio. Interpretação do Direito Previdenciário. São Paulo: Quartier Latin, 2007. p. 98-99.
} 
Se o direito previdenciário é um direito social fundamental, nada mais correto do que utilizar o texto normativo constitucional como mecanismo embasador para interpretação da norma jurídica com vistas à solução dos litígios que envolvam tal temática.

Deste modo, toda interpretação do direito previdenciário deve ser feita à luz de uma leitura constitucional, principalmente porque demandam posturas positivas por parte do Estado a fim de garantir a observância da proteção previdenciária. Tem-se, portanto, para esse caso, uma atividade constitutiva de interpretação da lei. ${ }^{294}$

A interpretação da lei para o Direito Previdenciário, portanto, deve ser feita a partir da análise do texto constitucional e, primordialmente, dos princípios constitucionais formadores da Constituição, de forma a obter os conceitos e as definições de seguridade social, além das relações sociais ideais a serem preservadas (dever ser). ${ }^{295}$

É justamente essa relação ideal que se depreende da interpretação do direito previdenciário à luz da Constituição Federal. A análise do dever ser pauta a interpretação do direito no sentido de sustentar a inteligência e a aplicação do texto normativo em cada caso concreto, transformando-o em norma a ser respeitada.

A interpretação constitucional para direitos fundamentais sociais depende fundamentalmente da interpretação dos princípios constitucionais. Essa interpretação, por comportar uma extensa gama de possibilidades, na medida em que os princípios permitem variados níveis de satisfação, tende a gerar dificuldades para estabelecer posições definitivas ou uníssonas, de forma a estabelecer uma norma a ser aplicada in concreto.

Assim, para solução dessa questão, recorre-se à ideia da existência de dois superprincípios, os quais devem ser utilizados como parâmetros balizadores da intepretação constitucional com vistas à aplicação da norma jurídica. Assim, a interpretação do direito social a partir dos princípios constitucionais deve sempre considerar como elementos balizadores a dignidade humana e a democracia. Isso porque o próprio texto constitucional é

\footnotetext{
${ }^{294}$ NASCIMENTO, op. cit., p. 97.
}

${ }^{295}$ CORREIA, op. cit., p. 253-254. 
claro ao elencar esses dois referenciais como essenciais ao Estado Democrático de Direito, que rege todo o nosso ordenamento jurídico. ${ }^{296}$

Sendo o Direito um reflexo das relações humanas em sociedade, e o Direito Previdenciário o reflexo das conquistas humanas em direitos sociais, por óbvio sua interpretação está sujeita a variações conforme o momento histórico apresentado: as exigências de proteção previdenciária na época da promulgação da Constituição de 1988 certamente já se tornaram mais complexas e diferenciadas atualmente. Por esta razão, se torna essencial que sua interpretação seja sempre realizada à luz dos ideais de dignidade humana e em respeito à democracia, não sendo permitidas interpretações tão somente baseadas na realidade circunstancial dos fatos, sob pena de se ter uma Constituição servil e juridicamente insegura. $^{297}$

A compreensão de um sistema de seguridade social, em especial, de previdência social, interpretado a partir do texto constitucional e de seus princípios fundantes, deve necessariamente considerar, portanto, a dignidade humana como elemento essencial para o estabelecimento dos conceitos, definições e normas jurídicas sobre a matéria.

Ainda, a interpretação do direito previdenciário a partir dos princípios constitucionais deve levar em conta sua natureza de direito fundamental, considerando seu núcleo essencial como parte irretocável de sua estrutura. Isso significa que toda interpretação e aplicação de direito previdenciário deve necessariamente verificar o que é nuclear no conceito interpretado, de forma a não invadí-lo e promover retrocesso social.

Dentro dessa perspectiva é possível identificar que, pela noção de direito fundamental social, o conceito constitucional de direito previdenciário tem caráter nuclear, não estando sujeito a interpretações que venham a lhe retirar e/ou limitar a eficácia. Isso porque, o direito à previdência (segurança social) é decorrente da conquista evolucionista humana.

O mesmo raciocínio pode ser aplicado aos benefícios previdenciários concedidos em razão das contingências previstas na Constituição de 1988. A interpretação da concessão dos benefícios deve ser feita a partir do entendimento de que são aspectos nucleares do direito

\footnotetext{
${ }^{296}$ CORREIA, op. cit., p. 259.

${ }^{297}$ Ibid., p. 260.
} 
fundamental à previdência social, na medida em que não existe previdência sem benefícios. Inclusive, a interpretação do direito previdenciário deve, necessariamente, levar em consideração o objetivo intrínseco ao próprio direito fundamental à previdência social, que é a proteção do indivíduo face a circunstâncias que o impeçam de prover sua subsistência e de sua família, a fim de estabelecer e garantir uma unidade político-constitucional a partir do entendimento do que é justo dentro dos conceitos de justiça constitucional. ${ }^{298}$

Por outro lado, alguns aspectos puramente organizacionais da matéria podem se sujeitar a alterações e interpretações de acordo com as necessidades contingenciais e fáticas da sociedade atual, desde que não estejam relacionados ao núcleo essencial do direito previdenciário.

Em resumo, pode-se observar que o direito à previdência social, em razão de sua característica fundamental, deve ser interpretado a partir do texto e dos princípios constitucionais, de forma que as demais regras e normas se adaptem e sejam produzidas em consonância com aquele entendimento. A partir dessa constatação, a leitura dos direitos previdenciários deve buscar a maximização dos resultados, com respeito ao núcleo essencial e com vistas à dignidade humana.

\subsection{Definição, estrutura e fundamento do direito à Previdência Social}

\subsubsection{Definição}

Diante de tudo o que foi debatido neste trabalho, amplamente demonstrada a fundamentalidade dos direitos sociais, em especial do direito à previdência social.

A seguridade social, e sua principal vertente, a previdência social, traduz-se em um dos mais importantes direitos humanos sociais, uma vez que promove a proteção da dignidade da pessoa humana a partir da garantia ao bem estar com justiça social. ${ }^{299}$

\footnotetext{
${ }^{298}$ CORREIA, op. cit., p. 262/265.

${ }^{299}$ FERREIRA, op. cit., p. 194.
} 
Sua principal função reside na garantia de um mínimo essencial à população, ou seja, um patamar mínimo de condição de vida adequada, de modo a eliminar a exclusão e/ou marginalização social em sociedades em há grandes indícios de desigualdade.

Dentro dessa perspectiva, o reconhecimento do direito fundamental à previdência social assegura o pleno exercício dos demais direitos e garantias fundamentais, na medida em que, ao promover a coesão social, garante que todo e qualquer indivíduo possa ter seus direitos plenamente observados e resguardados perante a sociedade, viabilizando sua dignidade. Isso porque a marginalização social e o estado de necessidade são os principais catalisadores da supressão de direitos humanos.

É tarefa do Estado assegurar a implementação de medidas que garantam a proteção e aplicabilidade do direito à previdência social com todos os meios e recursos possíveis, podendo, em caso de omissão, ser responsabilizado pela violação de direitos subjetivos dos indivíduos da sociedade. ${ }^{300}$

Indiscutível a natureza fundamental do direito social à previdência social, torna-se corolário lógico desse entendimento a existência de um núcleo essencial desse direito, intransponível para sua garantia e proteção, a exemplo do que ocorre com os demais direitos fundamentais, e medida limítrofe para a atuação do retrocesso social.

A questão que ora se apresenta é, portanto, delimitar esse núcleo essencial do direito fundamental à previdência social, de forma a inviabilizar qualquer medida que atente à sua observância.

Conforme já defendido anteriormente, quando se trata de direitos sociais, econômicos e culturais, a questão do núcleo essencial apresenta enfoque um tanto quanto diverso, por meio da impossibilidade de extinção do respectivo direito sem a devida substituição ou equivalência.

Isso significa que, além da necessária garantia e proteção de um mínimo necessário à obtenção do que se quer ver protegido (no presente caso, um patamar mínimo de condição de

\footnotetext{
${ }^{300}$ FERREIRA, op. cit., p. 199.
} 
vida adequada frente a contingências imprevisíveis que impossibilitem a subsistência), há que se estabelecer um mínimo de segurança jurídica, de forma a garantir a eficácia e a aplicabilidade desse direito.

Ou seja, o núcleo essencial do direito à previdência social apresenta dupla vertente: positiva, no sentido de garantir o mínimo necessário à sobrevivência e evitar a marginalização social, e negativa, no sentido de garantir a segurança jurídica quanto à eficácia e efetividade do próprio direito, a partir da abstenção de práticas administrativas ou alterações legislativas que coloquem em risco o standard mínimo já alcançado e incorporado ao patrimônio jurídico do segurado. ${ }^{301}$

Perpassada a questão da identificação do núcleo essencial do direito à previdência social, cabe, neste momento, definir sistematicamente o direito à previdência social dentro do ordenamento jurídico brasileiro.

O modelo constitucional brasileiro agrega previdência social, assistência social e saúde como vertentes da Seguridade Social, que traduz-se essencialmente no direito à segurança econômica, de forma a contribuir para a melhora da situação das classes sociais, seja na defesa contra situações de necessidade, seja na superação das adversidades, sempre com vistas a elevar o nível de vida dos cidadãos e a garantir a inclusão e a coesão social. ${ }^{302}$

A Previdência Social, principal vertente da Seguridade Social, por seu turno, nada obstante também ter como objetivo a proteção social em caso de infortúnios imprevisíveis que impeçam a manutenção da subsistência do indivíduo, relaciona-se mais especificamente com a questão laboral-produtiva, apresentando-se na forma de substituição de salário ou remuneração. ${ }^{303}$ Por esta razão, tem caráter eminentemente contributivo, ou seja, somente há garantia da proteção social previdenciária quando é demonstrado o recolhimento das respectivas contribuições.

Ao contrário da Assistência Social, que pode ser entendida como a última esfera de proteção social, para o caso de o indivíduo não conseguir manter a si próprio nem ter direito a

\footnotetext{
${ }^{301}$ ROCHA, op. cit., p. 115.

${ }^{302}$ SERAU JUNIOR, Marco Aurélio. Seguridade Social como Direito Fundamental Material. Curitiba: Juruá, 2009. p. 150.

${ }^{303}$ SERAU JUNIOR, op. cit., p. 151.
} 
qualquer benefício previdenciário, e que, por esta razão permite uma ampla gama de formas de proteção, a Previdência Social, justamente por seu caráter contributivo, apresenta um quadro normativo muito elucidativo e denso, fazendo com que a vinculação do legislador se torne mais nítida e necessária. ${ }^{304}$

Em razão de sua natureza contributiva, a Previdência Social promove contornos mais delimitados para a relação jurídica dela decorrente. Consequentemente, a questão econômica não pode ser sustentada como alegação para a não observância de benefícios previdenciários ou para alterações nas formas de contribuição, desde que os requisitos tenham sido devidamente preenchidos pelo interessado. ${ }^{305}$

É em razão da previdência social estabelecer um vínculo entre a capacidade contributiva e as prestações previdenciárias ofertadas, convertendo uma parte do resultado da atividade produtiva e a solidariedade social em proteção social individual e previsível, que se materializa uma expectativa jurídica legítima, nos beneficiários, de serem amparados em momentos de necessidade social. ${ }^{306}$

Portanto, tendo havido o respectivo pagamento em consonância com a forma da lei, tendo sido completados todos os requisitos legalmente exigidos para a obtenção de um benefício, denota-se o dever de atuação protetiva da entidade previdenciária. ${ }^{307}$ A ausência dessa atuação configura-se cristalino retrocesso social.

O conceito de Previdência Social, surge, deste modo, como uma forma de controle da desigualdade social e da concentração da renda, bem como para promover a diminuição da pobreza e a preservação da dignidade da pessoa humana. Tem como objetivo, em suma, a preservação dos direitos humanos a partir da realização de um padrão digno de vida a todos os cidadãos, com desenvolvimento social, cultural, econômico e político. ${ }^{308}$

E o principal desafio desse direito fundamental social é justamente ter uma implementação progressiva, com ampliação do alcance de proteção social a todos os indivíduos (atuação positiva), sem que isso implique também aumento nas formas de

\footnotetext{
${ }^{304}$ SERAU JUNIOR, op. cit., p. 152.

${ }^{305}$ ROCHA, op. cit., p. 114.

${ }^{306}$ Ibid., p. 114-115

${ }^{307}$ Ibid., p. 115.

${ }^{308}$ FERREIRA, op. cit., p. 208.
} 
contribuição ou redução e/ou restrição da proteção social já existente (atuação negativa), sob pena de se promover retrocesso social.

Para tanto,

Deve-se ter em mente que a solução desses desafios começa com uma alteração de postura em relação à seguridade social. Ao invés de se analisar a seguridade social através de um olhar estritamente econômico e financeiro, do impacto que esse sistema pode gerar nas contas publicas, deve-se olhá-la, antes de tudo, através do olhar social, do impacto que esse ordenamento de proteção social gera na vida das pessoas. ${ }^{309}$

\subsubsection{Estrutura}

Diante dos parâmetros e objetivos demonstrados, denota-se que a Previdência Social deve ser organizada de forma a atingir, com a maior eficácia e disponibilidade possíveis, os seus propósitos. Para tanto, faz-se necessária a observância de alguns princípios basilares, norteadores da criação e promovedores do desenvolvimento de um sistema coerente e justo.

A Constituição brasileira de 1988 sabiamente elencou alguns pontos referenciais para a criação de um Sistema de Seguridade Social, no qual a Previdência Social está embutida. Deste modo, à luz de toda a proteção necessária à garantia desse importante direito social, alguns desses princípios devem ser aplicados

É certo que a Previdência Social deve, portanto, ser compreendida a partir dos princípios da universalidade, da uniformidade, da seletividade e distributividade, da equidade da forma de participação no custeio, na diversidade na base de financiamento e na gestão democrática e descentralizada, a fim de garantir uma prestação justa, equânime, protetiva e, principalmente, eficiente.

Dentro da concepção de Previdência Social, o princípio da universalidade deve ser aplicado considerando-se o ideal de extensão geral do âmbito de proteção, mediante a respectiva contribuição, a todos os que se encontrem submetidos a contingências sociais que impeçam a manutenção da subsistência. Isso significa que a Previdência Social tem como

${ }^{309}$ FERREIRA, op. cit., p. 222. 
função a cobertura total dos riscos sociais que possam levar o indivíduo a situações de necessidade $^{310}$, atendendo a todos aqueles que fazem parte de seu programa. ${ }^{311}$

A partir de um sistema universalizado, a estrutura eficaz de sistema previdenciário pressupõe a uniformidade no atendimento a todos os participantes. Não é possível garantir uma universalidade no atendimento sem que todos os que participam do programa tenham acesso aos mesmos benefícios e serviços disponibilizados, independentemente de sua classificação social.

Nessa medida, participantes da esfera urbana ou rural, trabalhador ou não, que sejam vinculados à Previdência Social, terão sempre direito à mesma proteção social trazida pelo sistema, independentemente de sua localização física ou sua forma de participação (cujo reflexo apenas gera efeitos em termos valorativos).

A seletividade e distributividade dos benefícios e serviços previdenciários também visam garantir às finalidades estabelecidas pela ordem social prevista constitucionalmente. Assim, selecionam-se as contingências a serem atingidas pela proteção securitária, identificando seu nível de vulnerabilidade social e o grau de proteção necessário, distribuindo as prestações previdenciárias (disponibilizadas a todos) de forma a garantir o atingimento das mesmas àqueles que apresentarem maior necessidade. ${ }^{312}$

Nada obstante seu aparente contraponto ao princípio da universalidade, a seletividade e distributividade dos benefícios e serviços tem como objetivo tão somente aperfeiçoar a eficácia protetiva universalizada prevista na Constituição Federal, de forma a garantir a expressão da justiça social, na qual os níveis de proteção social são estabelecidos a partir das necessidades mais prementes.

A equidade na forma de participação no custeio, a exemplo dos princípios norteadores acima descritos, também é um reflexo da igualdade estabelecida em matéria de proteção social. Mais importante do que simplesmente discernir o montante da contribuição

\footnotetext{
${ }^{310}$ SAVARIS, op. cit., p. $140-141$.

311 A Seguridade Social brasileira estende-se, dentro do princípio da universalidade estabelecido pela Constituição Federal, a todos os cidadãos inseridos dentro do território nacional. A Previdência Social, por ser parte integrante do Sistema de Seguridade Social brasileiro também assume a concepção de universalidade, porém, limitada àqueles participantes do programa, ou seja, aos contribuintes do sistema de Previdência Social.

${ }^{312}$ SAVARIS, José Antonio. op. cit. p. 143.
} 
previdenciária a partir das condições econômicas de cada participante e/ou mero contribuinte ou a partir do risco social inerente a cada atividade econômica, por meio desse princípio, há a garantia de que ninguém será obrigado a contribuir além de suas possibilidades e que, ademais disso, não será prejudicado ou terá sua proteção social reduzida ou inviabilizada em consequência de suas limitações econômicas.

A par da equidade na participação, como forma de permitir a viabilização de um sistema previdenciário eficaz e eficiente, o custeio das prestações sociais conta também com uma diversificação nas possibilidades de financiamento, não se submetendo a uma rígida estrutura contributiva, que poderá comprometer a própria existência do sistema, em caso de ausência/impossibilidade de algum dos contribuintes. Deste modo, além de contar com uma gama de fontes de custeio (trabalhadores e não trabalhadores - estes, ainda que por opção -, empregadores, empresas no geral, participantes de concurso de prognósticos, importadores, etc.), o princípio da diversidade ainda permite uma redistribuição interna de recursos entre os vários setores da sociedade, à luz do princípio da equidade.

Por fim, o princípio da gestão democrática e descentralizada, com a participação do governo e da sociedade nas ações e decisões envolvendo a matéria previdenciária, traduz-se em um reflexo do próprio elemento central da ordem constitucional brasileira, trazida pelo parágrafo $1^{\circ}$, da Constituição Federal de $1988^{313}$ : a democracia participativa. Por ser o povo o sujeito da democracia e, principalmente, por ser a sociedade o objeto da proteção previdenciária (além, obviamente, de principal mantenedora da estrutura previdenciária), nada mais justo e correto do que garantir sua participação efetiva na gestão do sistema securitário em geral.

No caso específico da Previdência Social no Brasil, a gestão quadripartite (governo, trabalhadores, empregadores e aposentados) do sistema é realizada por meio do Conselho Nacional de Previdência Social (CNPS), cuja função é atuar no acompanhamento e avaliação dos planos e programas previdenciários promovidos pela Administração Pública, com vistas a um melhor desempenho nos serviços previdenciários prestados à sociedade. ${ }^{314}$

\footnotetext{
313 "Todo poder emana do povo, que exerce por meio de representante eleitos ou diretamente, nos termos dessa Constituição."

314 Conforme descrição trazida pelo Ministério da Previdência Social. Disponível em $<$ http://www.mps.gov.br/conteudoDinamico.php?id=43> . Acesso em 27 de outubro de 2012.
} 
Denota-se, portanto, que a estrutura previdenciária brasileira vem sendo construída de forma a permitir que a proteção social seja amplamente externalizada de forma eficiente, produtiva e justa. Cada conquista social no âmbito previdenciário deve ser assumida e garantida, sob pena de se configurar retrocesso social.

\subsubsection{Do Custeio}

A manutenção de um sistema de proteção social depende da existência de um financiamento disponibilizado para tanto. Dentro das vertentes da Seguridade Social brasileira, apenas a Previdência Social apresente caráter eminentemente contributivo. Isso significa que, para participar do programa, o interessado deverá contribuir financeiramente para o mesmo.

Conforme já visto anteriormente, essa contribuição é feita com estrita observância dos princípios da equidade na forma de participação e da diversidade da base de financiamento. E por se tratar de princípios voltados à proteção de direitos sociais, não obstante seu caráter claramente tributário, também estão sujeitos à aplicabilidade de um outro princípio fundante: o da proibição do retrocesso social.

O sistema de financiamento da Seguridade Social brasileira como um todo e da Previdência Social brasileira em particular adota um modelo de repartição para recolhimento e distribuição dos montantes das contribuições. Nesse modelo, ao contrário da capitalização $^{315}$, no qual a contribuição é recolhida mensalmente em uma reserva ou fundo individual de cada contribuinte (a exemplo do FGTS), toda as contribuições são reunidas em um fundo único, que é utilizado para o pagamento das prestações previdenciárias a quem delas necessite, em uma verdadeira noção de solidariedade, conforme será visto a seguir.

Dentro desse contexto, o custeio da Previdência Social tem como escopo garantir financeiramente a efetivação dos direitos sociais previdenciários, por meio da concessão de benefícios e serviços a quem deles necessite em determinada situação de vulnerabilidade social. Na prática, a sociedade economicamente ativa contribui para o manutenção das prestações previdenciárias daqueles que se encontram inativos, seja em razão da idade, da

\footnotetext{
${ }^{315}$ Apenas oito países adotam o modelo de capitalização: Chile, Peru, Argentina, Colômbia, Uruguai, México, Bolívia e El Salvador.
} 
fragilidade da saúde ou em consequência de alguma circunstância social que o impeça de prover seu próprio sustento naquele momento.

Nesse primeiro aspecto do custeio já é possível delimitar a atuação estatal no sentido de não cometimento de retrocesso social. O sistema de repartição é um sistema baseado em um modelo de solidariedade entre os indivíduos (de mesma geração e de gerações subsequentes, conforme se verá adiante), de modo a garantir a sobrevivência dos cidadãos em caso de contingência social que impeça sua subsistência. Todos contribuem conjuntamente para a manutenção dos mais necessitados.

Para além de um simples sistema de financiamento de benefícios e serviços é um modo de garantia de inclusão social e de manutenção da dignidade mesmo em circunstâncias adversas. Deste modo, não pode ser suprimido, modificado, reduzido ou limitado, sem a organização de outro sistema igualmente eficaz e igualmente protetivo, sob pena de se proceder a um retrocesso social.

Por outro lado, é necessário fazer com que o sistema de financiamento seja economicamente viável para garantir que os benefícios e serviços da Previdência Social sejam mantidos e disponibilizados de maneira eficiente a fim de resguardar seu papel de importante mecanismo de proteção social. ${ }^{316}$

Grandes questões se apresentam e devem ser enfrentadas na busca pela sustentabilidade financeira de um sistema de financiamento da Previdência Social. Problemas como o envelhecimento da população, a própria capacidade de gerenciamento de um sistema de custeio e a influência da globalização são temas recorrentes não só no Brasil, mas também em outros países do mundo.

A opção pela alteração no modelo de gerenciamento do sistema de financiamento (repartição para capitalização, por exemplo) não encontrou bons resultados na experiência internacional. Além de ser claramente prejudicial ao indivíduo, na medida em que o resultado final do investimento individual está eminentemente vinculado à economia e ao mercado de capitais interno, cuja flutuação e instabilidade pode reduzir ou mesmo inviabilizar a proteção

\footnotetext{
${ }^{316}$ FERREIRA, op. cit., p. 212.
} 
social, configurando retrocesso social, tal alteração ainda não resolveu a questão da eficiência administrativa, principalmente em consequência do aumento dos custos administrativos e das distorções econômicas.

A questão do envelhecimento da população surge a partir do avanço da medicina e do desenvolvimento de políticas de assistência e vigilância sanitária e atinge diretamente o modelo de repartição, na medida em que se reduz o número de pessoas economicamente ativas e se verifica um aumento no números de beneficiários do sistema de previdência social (idade avançada, fragilidade da saúde, etc.), que por sua vez, recebem as prestações durante um período maior tempo. ${ }^{317}$

Dentro dessa perspectiva, faz-se necessária uma reavaliação do sistema de forma a se adaptar às novas mudanças trazidas pelo desenvolvimento humano. Contudo, é imprescindível ter em mente, à luz do princípio da proibição do retrocesso social, a impossibilidade de qualquer modificação que promova a redução dos direitos sociais anteriormente garantidos, a limitação do acesso aos mesmos ou a modificação daqueles sem uma correspondente substituição igualmente protetiva e eficaz. Deste modo, a percepção de novos modelos de financiamento do sistema de previdência social deve buscar soluções viáveis a partir do mercado de trabalho e de novas políticas econômicas e sociais ${ }^{318}$, sem que o que nível de proteção já garantido sofra qualquer revés.

O gerenciamento de um sistema de financiamento sempre é um ponto polêmico e complicado de se abordar. Isso porque essa questão normalmente enfrenta problemas tanto de ordem econômica quanto de ordem social.

A capacidade de gerir um sistema envolve solucionar impasses quanto à frequente necessidade de redução de gastos, quanto ao constante aumento dos custos previdenciários do trabalhador, quanto ao próprio envelhecimento da população e a consequente mudança na estrutura demográfica, e até mesmo quanto a circunstâncias sociais que afetam a organização previdenciária, como o trabalho informal, o desemprego e a recessão econômica. ${ }^{319}$

\footnotetext{
${ }^{317}$ FERREIRA, op. cit., p. 214-215.

318 Ibid., p. 216.

${ }^{319}$ FERREIRA, op. cit., p. 219.
} 
Nessa medida, para ser preparado e eficiente, o gerenciamento do sistema de financiamento da previdência social tem que ser capaz de lidar habilmente com todos os pontos que possam afetar o seu equilíbrio, considerando todas as vertentes econômicas e sociais que possam intervir nessa relação. E isso tudo, sem afetar o direito fundamental à previdência social, dentro de seu princípio de universalidade da cobertura e do atendimento $^{320}$, sob pena de se configurar retrocesso social.

Portanto, a capacidade de um gerenciamento adequado para o sistema de financiamento da previdência social é medida de extrema importância para a viabilização do próprio direito fundamental social.

Por fim, um último aspecto merece ser considerado no âmbito na avaliação da importância do custeio na promoção dos direitos sociais previdenciários e cuja influência tem gerado situações nas quais o retrocesso social resta mais evidente. Trata-se de um dos grandes desafios da Previdência Social na atualidade e um dos que mais afeta o custeio do sistema e a busca por uma eficácia contínua na proteção dos direitos sociais previdenciários: a globalização.

O advento da globalização promoveu, além da abertura comercial e financeira entre os países, uma competição desenfreada entre os mesmos a fim de atrair maiores e melhores investimentos, na medida em que foram liberadas as fronteiras econômicas e sociais no mundo. Essa competição tem como principal entrave os custos operacionais da instalação de um novo negócio, aí incluindo, quase que em sua totalidade, os custos relacionados ao trabalhador.

Como consequência do aumento da competitividade e da facilidade de deslocamento de investimentos e pessoas, travaram-se discussões acerca da necessidade de se promover uma redução dos custos trabalhistas e, principalmente, previdenciários. E a redução desses custos acarretará a diminuição na arrecadação de recursos para custeio das prestações previdenciárias o que indubitavelmente afetará o nível de proteção social garantido às pessoas. $^{321}$

\footnotetext{
${ }^{320}$ FERREIRA, op. cit., p. 219.

${ }^{321}$ Ibid.
} 
Deste modo, à luz da necessidade de proteção aos direitos fundamentais e, principalmente, de garantia da dignidade humana, faz-se necessária a busca por alternativas válidas e eficazes que impossibilitem a redução dos direitos sociais já consagrados e garantidos sem limitar a competitividade frente à uma estrutura globalizada.

A eficiência na gestão do sistema de financiamento, com a redução de gastos injustificados e a vedação do escoamento das verbas sociais para fontes não voltadas à efetiva proteção social é apenas o primeiro passo de uma jornada em busca do pleno reconhecimento e garantia dos direitos sociais como um todo, e securitários, como a previdência social, em particular.

Deve-se ter em mente que a solução desses desafios começa com uma alteração de postura em relação à seguridade social. Ao invés de analisar a seguridade social através de um olhar estritamente econômico e financeiro, do impacto que esse sistema pode gerar nas contas públicas, deve-se olhá-la, antes de tudo, através do olhar social, do impacto que esse ordenamento de proteção social gera na vida das pessoas.

Deve-se analisar a seguridade social não somente pelo lado financeiro, mas, sobretudo, pela razão principal de sua existência: ser um mecanismo de preservação dos direitos humanos, da dignidade e do combate às vicissitudes da vida. ${ }^{322}$

\subsubsection{Das Prestações}

Já foi mencionado neste estudo que a Previdência Social tem como principal objetivo a manutenção do indivíduo quando sujeito à contingência social, constitucionalmente prevista, que o impeça de prover seu próprio sustento e de sua família.

Portanto, a Constituição Federal de 1988 traz em seu bojo um rol de situações que podem impedir o cidadão de exercer amplamente sua dignidade, na medida em que retira ou dificulta sua possibilidade de subsistência: desemprego, maternidade, prisão, idade avançada, doença, invalidez, morte.

A partir das contingências listadas na Constituição como objeto de proteção social, o sistema de Previdência Social estabelece prestações a serem garantidas ao usuário do sistema como contraprestação aos riscos sociais a que está submetido em determinado momento. Vale

${ }^{322}$ FERREIRA, op. cit., p. 222. 
lembrar que a Previdência Social brasileira é um sistema eminentemente contributivo, como analisado acima, de modo que as prestações previdenciárias garantidas a partir da configuração de uma contingência social somente serão destinadas àqueles que contribuem para o sistema, chamados, assim, de segurados.

Dentro dessa medida, pode-se definir prestação previdenciária como o mecanismo para atendimento às necessidades vitais da sociedade, face à obrigatoriedade do Estado em respeitar e assegurar a dignidade da pessoa humana. ${ }^{323}$

As prestações previdenciárias correspondem às obrigações impostas ao ente público pela ordem jurídica, a fim de que sejam minimizados os efeitos das contingências sociais. ${ }^{324}$

As prestações previdenciárias podem ser subdivididas em benefícios e serviços, sendo as primeiras prestações consubstanciadas na entrega de certo montante em pecúnia e os segundos, em atividades que visem à plena recolocação do indivíduo ativamente na sociedade, a exemplo dos serviços de reabilitação.

A escolha da melhor forma de prestação, em termos de maior eficiência no atendimento ao cidadão e eficácia do direito social a ser protegido, é feita pelo legislador infraconstitucional, à luz do princípio da seletividade e distributividade dos benefícios e serviços. Dentre o montante de possibilidades, o legislador faz a opção pela que atende aos ditames constitucionais da forma mais abrangente possível, a fim de garantir a amplitude dos direitos fundamentais sociais.

Assim, por exemplo, quando a Constituição garantiu a proteção em caso de idade avançada, o legislador infraconstitucional optou pela escolha do benefício da aposentadoria, em suas modalidades por idade e por tempo de contribuição. Quando fala de doença ou invalidez, o legislador optou pelo benefício do auxílio-doença, da aposentadoria por invalidez e pelo serviço da reabilitação, conforme a situação em que o indivíduo segurado pelo sistema se encontre. E assim sucessivamente para todas as contingências elencadas na Constituição.

\footnotetext{
${ }^{323}$ SERAU JUNIOR, op. cit., p. 156.

${ }^{324}$ ROCHA, Daniel Machado da. Uma Contribuição para o Estudo da Relação Jurídica de Previdência Social. Curso de Especialização em Direito Previdenciário. Org. Daniel Machado da Rocha e José Antonio Savaris. vol. 2. $1^{\text {a }}$ ed., $2^{\mathrm{a}}$ tir. Curitiba: Juruá, 2006. p. 40.
} 
Não é o caso aqui de se pontuar todos os benefícios e serviços oferecidos pela Previdência Social brasileira, já que foge ao escopo do presente estudo. Mesmo porque a sistemática de avaliação do objeto da proteção social é a mesma para qualquer prestação previdenciária, estando todas vinculados à garantia da dignidade humana a partir da inclusão social em caso de situação de necessidade.

Denota-se, portanto, que as prestações concedidas pela Previdência Social têm como escopo garantir a sobrevivência do indivíduo que faz parte do sistema (segurado) durante o período em que atingido por uma contingência social que o impossibilita de prover o próprio sustento e de sua família. Ou seja, são prestações concedidas com o objetivo de garantir a dignidade humana mesmo em situações adversas, evitando-se a exclusão social.

Por esta razão é que as prestações de cunho previdenciário devem ser analisadas à luz do direito fundamental social à Previdência Social, haja vista que garantem a sua observância e sua aplicabilidade. Dentro dessa perspectiva, qualquer alteração na estrutura das prestações concedidas deve estar submetida ao princípio da proibição do retrocesso social.

Já foi mencionado alhures que o direito fundamental social, independentemente de sua definição, demanda posição/atuação ativa e negativa do Estado. Negativa no sentido de abster-se de qualquer medida que coloque em risco sua existência e eficácia e ativa (ou positiva) no sentido de exigir que o Estado promova medidas que garantam a sua aplicabilidade imediata.

No caso específico das prestações previdenciárias, essa obrigação estatal se apresenta de uma forma bem mais clara. Deve o Estado, a exemplo dos demais direitos fundamentais, se posicionar no sentido de impedir a eliminação ou a limitação ao direito de ter proteção previdenciária. Por outro lado, mais além, deve garantir sua observância e aplicabilidade a partir da criação de políticas que viabilizem o acesso ao direito fundamental à Previdência Social. Em ambas as hipóteses, a questão deve ser analisada à luz do princípio da proibição do retrocesso social.

Em uma visão da atuação negativa do Estado, essa questão surge de forma cristalina: qualquer tentativa de remover o direito de proteção previdenciária, consubstanciado no fornecimento de benefícios e serviços, ou limitar os seus efeitos, padece de retrocesso social, 
figura proibida no ordenamento jurídico brasileiro. Isso porque a proteção previdenciária perfaz o núcleo essencial do direito fundamental à Previdência Social.

Portanto, sob esse aspecto, a prestação previdenciária se torna elemento essencial para a efetivação do direito à Previdência Social, de modo que o Estado deve se abster de práticas que coloquem em risco a garantia deste direito. Em resumo, respeitar a existência do mesmo e seus efeitos e garantir que esse direito fundamental atinja seus escopos.

Por outro lado, é na atuação positiva do Estado nas questões previdenciárias, que o princípio da proibição do retrocesso social ganha nuances um pouco mais diversificadas. Dentro dessa perspectiva, não basta apenas abster-se de práticas que promovam a eliminação ou a limitação do direito fundamental à Previdência Social. Aqui, a posição do Estado é no sentido de garantir, na prática, que esse direito seja realmente observado, por meio de medidas específicas que lhe assegurem um mínimo de eficácia, a partir de uma noção de dignidade humana. É justamente em uma constituição com características dirigentes que a questão do retrocesso social apresenta contornos mais apurados e, por consequência, se torna mais difícil de se analisar e aplicar. Não se trata mais, pois, da mera existência do direito fundamental previdenciário, mas da abrangência e extensão dessa existência, do que já foi conquistado e garantido por meio das prestações previdenciárias.

Em se tratando de direito fundamental de cunho social, é imprescindível a atuação do Estado para efetivação de tais direitos. Corolário lógico desse raciocínio é que para a efetivação do direito fundamental à Previdência Social necessário se faz que o Estado produza normas que contenham as formas pelas quais a proteção aos riscos sociais se dará. Ou seja, como o Estado irá atender ao indivíduo submetido a um risco social considerado relevante pela Constituição? Em outras palavras, quais prestações serão fornecidas quando demonstrada a situação de necessidade do indivíduo face a uma contingência social constitucionalmente prevista.

Para atender às exigências da Constituição Federal, portanto, o Estado estabelece, por meio de leis infraconstitucionais, quais os benefícios e serviços serão prestados em caso de ocorrência de cada uma das contingências elencadas. E essa decisão considerará o mínimo necessário de proteção, da forma mais abrangente possível, com vistas a garantir que o indivíduo seja restabelecido na sociedade e, consequentemente, mantenha sua dignidade. 
Dentro dessa concepção, tem-se que a opção feita pelo legislador, em cada hipótese de contingência social, é a melhor forma encontrada, considerando fatores econômicos e sociais, para garantir o direito fundamental à Previdência Social caso submetido a uma situação considerada adversa. Portanto, qualquer redução ou alteração tem, necessariamente, garantir que (i) o mínimo garantido seja observado; e (ii) que a extensão da proteção alcançada até aquele momento não sofra qualquer revés, sob pena de se resvalar em retrocesso social.

A título de exemplo, pode-se analisar a questão da contingência social doença. A Constituição Federal garante proteção previdenciária para o indivíduo segurado que é acometido temporariamente de uma doença que o impeça de exercer sua atividade laborativa e prover seu sustento e de sua família. Nessa hipótese, o legislador infraconstitucional previu a concessão de um benefício previdenciário denominado auxílio-doença, que é fornecido enquanto perdurar a enfermidade.

Esse benefício é garantido indistintamente a qualquer segurado da Previdência Social mediante a observância de alguns requisitos, tais como carência e comprovação da doença por um atestado médico oficial do órgão concessor do benefício (no caso o Instituto Nacional de Seguridade Social - INSS).

Optou, portanto, o legislador, que o direito fundamental à Previdência Social, no caso de doença, seria garantido da melhor forma possível por meio da concessão do benefício do auxílio doença, com as regras acima listadas. E se é o mínimo garantido, qualquer alteração inadequada, injustificada e sem a devida substituição por outra forma igual ou mais protetiva, não encontra qualquer respaldo na dinâmica dos direitos sociais. É nesse aspecto que se torna prejudicial ao indivíduo e, portanto, matéria de retrocesso social.

Denota-se que, uma vez estabelecida uma forma de proteção previdenciária, seja sob qualquer modelo de prestação, ela se torna uma conquista no indivíduo de ter sua dignidade preservada. Eventual alteração nessa sistemática somente pode ser vislumbrada em progressivo crescimento ou em eventual reversibilidade restrita à proteção do núcleo essencial, sem contudo, desconsiderar o que já foi admitido (e interiorizado) na esfera jurídica do indivíduo. A projeção retroativa, nesse sentido, atinge o núcleo essencial do direito à 
proteção previdenciária, já que inviabiliza a garantia minimamente considerada e reproduz efeitos retrocessivos.

Importante ressaltar que essa análise não conduz à afirmação de que a proteção previdenciária uma vez garantida se torna imutável ou impassível de qualquer revisão. Como a própria sociedade é dinâmica e o ordenamento jurídico deve necessariamente seguir os passos do desenvolvimento social, todo e qualquer direito fundamental deve ser adaptado às novas exigências do homem e de sua dignidade.

Contudo, as revisões, modificações e ponderações havidas não podem resultar na redução inadequada, arbitrária ou injustificada de direitos já consagrados e incorporados no consciente coletivo, considerando o mínimo anteriormente assegurado.

Toda e qualquer alteração deve ser inicialmente precedida de uma necessária justificativa constitucional e, posteriormente, da aplicação de uma medida substitutiva ou equivalente, de forma a garantir o nível mínimo de concretização já garantido, sob pena de atingimento do núcleo essencial do direito fundamental e, consequentemente, de ofensa ao princípio da proibição do retrocesso social.

Iremos revisitar essa análise do retrocesso social em prestações previdenciárias em quatro situações diferentes, ocorridas no decorrer dos últimos anos e que tiveram reflexo direto para indivíduos em sociedade.

\subsubsection{Fundamento formal e material}

Os direitos humanos, reconhecidos como indispensáveis ao desenvolvimento do ser humano, tornam-se fundamentais a partir de sua positivação em cada ordenamento jurídico. Essa positivação de direitos, individuais ou sociais, baseia-se em fundamentos formais e materiais, a partir da própria identidade constitucional e da estrutura sobre a qual o Estado é formado.

Fundamentos formais podem ser traduzidos pela própria posição jurídica decorrente do enunciado expressamente consagrado no texto constitucional. Assim, o fundamento formal dos direitos sociais (e da previdência social), por exemplo, está acolhido de forma irrefutável 
e não exaustiva no artigo $6^{\circ}$ da Constituição Federal brasileira (educação, saúde, trabalho, moradia, lazer, segurança, previdência social, entre outros). ${ }^{325}$

A fundamentalidade material, de outro turno,

decorre do reconhecimento de que determinados direitos, integrando a essência do Estado Constitucional e constituindo prioridades do ordenamento jurídico, contribuem decisivamente para a dignificação da pessoa humana. ${ }^{326}$

Provém, portanto, do entendimento de que determinado direito, a partir de uma gama de posições jurídicas, abrangendo princípios, deveres, direitos, competências, ações estatais positivas e negativas $^{327}$, tem sua atuação voltada para a concretização dos objetivos elencados como relevantes pelo constituinte originário, tais como a justiça e a dignidade humana. ${ }^{328}$

Essa questão da fundamentalidade material ou jusfundamentalidade dos direitos sociais (aí incluindo o direito à previdência social) não é unanimemente acolhida pela doutrina pátria. Há autores que sustentam a inexistência dessa jusfundamentalidade e outros que apenas vinculam a fundamentalidade material dos direitos sociais ao mínimo existencial.

A questão da mera negativa de jusfundamentalidade é claramente rebatida pela simples análise da estreita vinculação entre direitos sociais e dignidade humana e justiça social (combate à marginalização e desigualdade social). ${ }^{329}$

Por outro lado, a questão da fundamentalidade material encontrar-se baseada apenas no mínimo existencial (para além do mínimo, há a sujeição dos direitos sociais à reserva do possível) também não encontra melhor respaldo. Além de, conforme já mencionado anteriormente, ser estreita a ligação entre direitos sociais, dignidade humana e a necessária garantia de igualdade material dentro de um Estado Democrático de Direito, ${ }^{330}$ a própria

\footnotetext{
${ }^{325}$ ROCHA, op. cit., p. 110.

${ }^{326}$ Ibid., p. 110.

${ }^{327}$ SERAU JUNIOR, op. cit., p. 161.

${ }^{328}$ DERBLI, op. cit., p. 101-102.

${ }^{329}$ Ibid., p. 102.

330 “Destarte, é possível sustentar, desse ponto de vista, que a fundamentalidade material haverá de alcançar não apenas os direitos sociais vinculados ao mínimo existencial (vale dizer, os relacionados com a garantia da autonomia privada), mas também aqueles que se traduzam em condições sociais da democracia, isto é, os direitos sociais necessários a uma participação materialmente igual dos indivíduos na vida pública." (DERBLI, op. cit., p. 104).
} 
Constituição traz em sua ideologia a promoção da justiça social, de modo que é a justiciabilidade (exequibilidade) do direito que deve estar condicionada à sua jusfundamentalidade. ${ }^{331}$

No caso específico do direito à previdência social, a fundamentalidade material encontra-se consubstanciada na obrigação estatal de prover uma existência humanamente digna ao indivíduo que, em razão de algum risco social, encontra-se incapacitado de se manter dentro de um nível de subsistência minimamente adequado.

\subsubsection{Da questão da solidariedade}

Muito embora a caracterização de solidariedade já pudesse ser encontrada desde os remotos tempos da Antiguidade, sob a percepção de amizade, amor e união, ajuda mútua, irmandade e companheirismo, foi somente a partir da Revolução Francesa e seu ideal de fraternidade que a ideia de solidariedade moderna se difundiu. ${ }^{332}$

Essa fraternidade contemplaria no seu núcleo: a) uma amizade que alcança a todo gênero humano; b) um objetivo de comunidade ou de unidade; c) o uso comum de bens; d) uma ajuda mútua, a qual decorre do fato de cada um dever tratar o outro como gostaria de ser tratado. A solidariedade dos modernos emergiu como resposta à nova mentalidade econômica que negava espaço para a existência da solidariedade como virtude. ${ }^{333}$

Com o desenvolvimento da concepção de direitos humanos, a compreensão da solidariedade tornou-se definitiva para a consecução um bem estar coletivo, integrando todos os indivíduos, da melhor forma possível, na vida em sociedade. Dentro dessa perspectiva, a solidariedade deixa de ser considerada uma virtude ou uma forma de garantir o desenvolvimento econômico e passa a ser encarada com um valor integrante de uma sociedade juridicamente organizada, fornecendo as bases da convivência social. ${ }^{334}$

\footnotetext{
${ }^{331}$ BARROSO, Luís Roberto. O Direito Constitucional e a Efetividade de suas Normas: limites e possibilidades da Constituição brasileira. $9^{\mathrm{a}}$ ed. Rio de Janeiro: Renovar, 2009, p. 102.

${ }^{332}$ ROCHA, op. cit., p. 129.

${ }^{333}$ Ibid., p. 130.

${ }^{334}$ ROCHA, op. cit., p. 130.
} 
A partir dessa nova visão de solidariedade, desenvolvida em razão de uma consciência social (que, por sua vez, sustenta o surgimento dos direitos sociais) ${ }^{335}$, vislumbram-se as primeiras noções estruturais de previdência social nos moldes atualmente implantados.

Às voltas com os problemas de agravamento das condições de trabalho e da marginalização social criados pela Revolução Industrial, a sociedade passa a exigir do Estado uma intervenção efetiva no sentido de equacionar as dificuldades existentes, resultando na criação de um sistema de bem estar social (Estado Social de Direito), fundado nos ideais de cooperação mútua (Estado e sociedade) para atingimento de uma dignidade humana generalizada.

Apesar de poder ser considerada como princípio fundante dos direitos sociais, a questão da solidariedade não se restringe apenas ao aspecto da proteção social. Sua acepção está presente em todos os aspectos da convivência humana, garantindo, com isso, que a dignidade humana seja preconizada indistintamente sob toda e qualquer circunstância. ${ }^{336}$

Na Constituição Federal de 1988, a solidariedade foi materializada formalmente como princípio e objetivo fundamental do ordenamento jurídico brasileiro, com a clara intenção de fortalecer a sociedade em sua generalidade. Dentro de um Estado Democrático de Direito, no qual são consagrados como princípios fundantes a cidadania, a democracia e a dignidade humana, a questão da solidariedade se torna um compromisso não só natural ${ }^{337}$, mas primordial para toda a ordem constitucional.

Teve, portanto, o constituinte originário a intenção de enfrentar as desigualdades sociais e erradicar a pobreza, geradora de marginalização e segregação, a partir de um sistema

\footnotetext{
335 "A solidariedade prende-se à ideia de responsabilidade de todos pelas carências e necessidades de qualquer indivíduo ou grupo social. É a transposição, no plano da sociedade política, da obligatio in solidium do direito privado romano. O fundamento ético desse princípio encontra-se na ideia de justiça distributiva, entendida como a necessária compensação de bens e vantagens entre as classes sociais, com a socialização dos riscos normais da existência humana. Com base no princípio da solidariedade, passaram a ser reconhecidos como direitos humanos os chamados direitos sociais, que se realizam pela execução de políticas públicas, destinadas a garantir amparo e proteção social aos mais fracos e mais pobres; ou seja, aqueles que não dispõem de recursos próprios para viver dignamente." (COMPARATO, Fábio Konder. Afirmação Histórica dos Direitos Humanos. 7. ed. rev. e atual. São Paulo: Saraiva, 2010. p. 77).

336 "A solidariedade diferencia-se dos demais valores por fundamentar indiretamente os direitos, isto é, assegurálos à medida que os deveres são respeitados. A solidariedade constitucional, na lição de Perlingieri, atua limitando e funcionalizando os interesses protegidos pelo ordenamento jurídico, de forma a harmonizá-los com o interesse social. (ROCHA, op. cit., p. 133).

${ }^{337}$ ROCHA, op. cit., p. 134.
} 
de redistribuição de renda, consubstanciado no princípio da solidariedade e de justiça social, no qual todos têm acesso às vantagens sociais, com vistas à manutenção de um padrão de vida digno necessário à condição humana.

Mesmo a partir de uma concepção contratualista da sociedade, tem-se a essencialidade de um modelo de solidariedade. Se a sociedade é resultado de um pacto entre indivíduos, no qual são definidas as bases, os direitos individuais e sociais mínimos, além da determinação dos objetivos comuns da sociedade, como realizar tais tarefas sem que os membros estejam num ideal de participação, cooperação e auxílio mútuos?

No caso específico dos direitos sociais, a solidariedade surge como "uma necessidade fundamental para viabilizar o convívio em sociedade, ou seja, a prevenção e a reparação, na medida do possível, dos riscos sociais. " ${ }^{338}$ Assim, a solidariedade torna-se elemento essencial para a garantia de uma proteção social eficiente e eficaz, uma vez que justifica a participação de toda a sociedade no financiamento do sistema.

Com base em uma participação engajada de toda a sociedade é possível obter a supressão de situações de carência social e econômica dos membros da sociedade, utilizandose da contribuição dos mais afortunados para garantir condições de sobrevivência digna aos menos favorecidos. E é justamente esse o principal objetivo de um sistema de Seguridade Social, em especial de Previdência Social: garantir aos indivíduos menos favorecidos um padrão mínimo de subsistência para viver dignamente, de forma a também assegurar o fortalecimento do grupo social com um todo. ${ }^{339}$

A questão da participação engajada da sociedade, no entanto, para fins de garantia de uma proteção social ampla e irrestrita, deve ser analisada sob o aspecto da vontade e materialização da lei, como um comando para a pautar as ações sociais. Torna-se, nessa medida, além de ética, também obrigatoriamente observada.

Diante desse contexto, tanto o custeio como as prestações previdenciárias devem ser analisadas sob uma ótica de participação solidária, na qual todos contribuem para um fim

\footnotetext{
${ }^{338}$ ROCHA, op. cit., p. 136.

${ }^{339}$ FERREIRA, op. cit., p. 162-163.
} 
comum: a garantia de que, a partir do auxílio mútuo, todos terão uma proteção social justa em caso de necessidade atual ou futura.

\begin{abstract}
A solidariedade assume uma posição de destaque na seguridade social, já que permite que esse sistema de proteção social seja financiado por toda a sociedade para, quando um indivíduo for afetado por qualquer contingência, que acarrete a diminuição de sua renda, a ponto de não conseguir suprir as suas necessidades básicas para viver dignamente, possa ser assistido por uma prestação prevista pelo sistema, que permita a ele viver dignamente, enquanto perdurar o fato danoso. ${ }^{340}$
\end{abstract}

Na prática da garantia previdenciária, o princípio da solidariedade se consubstancia no aporte de recursos financeiros oriundos da sociedade, cujo montante será concentrado em um fundo único e comum, gerenciado pelo Estado com o objetivo de ser distribuído àqueles indivíduos que, em consequência de contingências sociais danosas, não detém condições de prover seu próprio sustento e sua família.

Esse sistema de solidariedade pode ocorrer de forma geral ou atual, ou entre gerações. A solidariedade geral ou atual é um sistema de cooperação entre a sociedade como um todo e o membro que necessita de ajuda naquele momento. Assim, em um mesmo momento da vida, os economicamente ativos contribuem para suprir as necessidades dos que estão fora do mercado de trabalho, os sadios para a manutenção dos doentes, os jovens para auxiliar os que já atingiram idade avançada, e assim sucessivamente.

Já na solidariedade entre gerações (ou intergeracional) engloba também a contribuição em favor daqueles que futuramente possam descobrir-se incapacitados de prover seu próprio sustento e de sua família. Essa modalidade de solidariedade social, contudo, nada mais é do que um desdobramento de uma concepção geral de auxílio e cooperação mútuos.

Em resumo, a questão da proteção previdenciária encontra respaldo também no princípio da solidariedade, expressamente esculpido no texto constitucional brasileiro. E por se tratar de um princípio absoluto, na medida em que é garantidor da dignidade humana e da efetivação da justiça social, elementos fundamentais da República Federativa do Brasil, resvala ao direito à previdência social a impossibilidade de se submeter a medidas retrocessivas que tenham como objetivo rever e/ou limitar sua eficácia.

${ }^{340}$ FERREIRA, op. cit., p. 164. 


\subsubsection{Da garantia institucional e do dever do Estado}

Face a tudo o que foi anteriormente analisado com relação a direitos humanos e sua convolação em direitos fundamentais, observa-se que tais direitos detém tal importância que sem eles o ser humano não encontra sua completa realização. Dentre os direitos humanos fundamentais, os direitos sociais, objeto desse estudo, assumem uma posição de extrema relevância na consagração de uma vida digna, na medida em que preveem a proteção das necessidades vitais e básicas do homem. ${ }^{341}$

São as necessidades sociais não atendidas que promovem desigualdade social, pobreza, marginalização, exclusão social e todas as formas degradantes de vida humana. Nessas circunstâncias, a ausência de dignidade humana é fator preponderante.

É na busca da erradicação dessas situações indignas e inadmissíveis, que os direitos fundamentais sociais encontram espaço para o desenvolvimento e a garantia de aplicabilidade imediata. No entanto, por se tratarem de direitos que, em sua essência, dependem de regulamentação estatal, a previsão e proteção constitucional não se revelam suficientes para sua completa eficácia. É nesse aspecto que a garantia institucional se torna premente.

A questão da garantia institucional é uma criação da doutrina alemã e compreendia as garantias jurídico-públicas e jurídico-privadas. Nada obstante ter embasamento e proteção constitucional, não se confunde com direito fundamental, na medida em que não se traduz em direitos atribuídos diretamente a uma pessoa, mas apenas reflete a proteção dos direitos fundamentais, individuais e sociais. ${ }^{342}$

Do ponto de vista da proteç̧ão jurídica constitucional, as garantias institucionais não garantem aos particulares posições subjectivas autónomas e daí a inaplicabilidade do regime dos direitos, liberdades e garantias. [...] A protecção das garantias institucionais aproxima-se da protecção dos direitos fundamentais quando se exige, em face das intervenções limitativas do legislador, a salvaguarda do "mínimo essencial" (núcleo essencial das instituições). ${ }^{343}$

\footnotetext{
${ }^{341}$ SIMM, op. cit., p. 115.

${ }^{342}$ CANOTILHO, José Joaquim Gomes. Direito Constitucional e Teoria da Constituição. 7. ed. Coimbra: Almedina, 2003. p. 397.

${ }^{343}$ CANOTILHO, op. cit., p. 397-398.
} 
Nessa medida, as instituições acabam por apresentar elementos diversos dos direitos fundamentais, recebendo proteção constitucional em razão de configurarem realidades sociais objetivas. $^{344}$ A instituição pode ser definida como o fenômeno jurídico no qual são apresentados esquemas regulativos para existência e funcionamento de normas constitucionais. $^{345}$

Portanto, inquestionável a garantia e a regulação constitucional das instituições. Faz-se necessário, contudo, identificar exatamente como pode se apresentar uma instituição sobre a qual repousa o amparo constitucional:

(1) um modelo de acção ou padrão de comportamento; (2) um espaço de ligação do indivíduo com outras pessoas ou com a sociedade; (3) uma estrutura de socialização e estabilização dos padrões de conduta e forma de comportamento. ${ }^{346}$

Apurada a existência de uma garantia institucional trazida pela Constituição e vinculada a um direito fundamental, pertinente se faz a verificação de instituições que assegurem a extensão dos direitos fundamentais sociais, em especial o direito à proteção em caso de contingência social prejudicial à manutenção de uma vida digna.

Em outras palavras, faz-se necessária a verificação se a Seguridade Social, em geral, e a Previdência Social, em particular, podem ser consideradas garantias institucionais, protegidas pelo manto constitucional e objeto da atenção do Estado e da sociedade.

Transportando a identificação de instituição assinalada por Canotilho para a realidade da Previdência Social é possível verificar que a mesma comporta todos os requisitos de uma instituição. Por primeiro, porque é um modelo de ação do Estado, na medida em que estabelece políticas de atuação social voltadas ao atendimento das necessidades básicas do indivíduos que se apresentem em situação de marginalização social, além de um padrão de comportamento, refletindo uma organização da própria sociedade. ${ }^{347}$

\footnotetext{
${ }^{344}$ CANOTILHO, op. cit., p. 397-398.

${ }^{345}$ Ibid., p. 1145.

${ }^{346}$ Ibid.

${ }^{347}$ SIMM, op. cit., p. 116.
} 
Por segundo, porque a concreta ligação entre todos os membros da sociedade está presente em razão do princípio da solidariedade, característico da Previdência Social, no qual todos se cotizam para garantir condições mínimas de sobrevivência digna aos sujeitos aos riscos sociais. ${ }^{348}$

E, finalmente, por terceiro, porque traduz-se também em um "regime ou plano de ação, de objetivos e de fins estruturado de forma sistêmica, tornando-se o arcabouço de um processo de socialização e estabilização do comportamento social." ${ }^{349}$

Portanto, nada mais concreto e razoável que analisarmos a Previdência Social, além de um direito fundamental social, também sob o prima de uma instituição destinada a promover e regular, esquematicamente, de forma eficiente e eficaz, as disposições constitucionais sob a questão da proteção previdenciária em face das agruras sociais.

E, consequentemente, por se tratar de uma garantia institucional, a Previdência Social (e a Seguridade Social como um todo), em sua estruturação, também conta com a proteção constitucional, sendo-lhe assegurada a segurança e a sobrevivência de sua condição de instituição.

E na condição de instituição, a Seguridade Social deve estar a salvo das crises econômicas, deve gozar da especial atenção do Estado e da sociedade, deve ser preservada como sistema de proteção e redistribuição de renda, deve estar acima e além de quaisquer fronteiras, inclusive as territoriais, albergando o ser humano onde ele se encontrar, independentemente da sua nacionalidade, das suas origens e das duas condições pessoais. ${ }^{350}$

Ainda, por se tratar de um garantia institucional, a proteção à instituição Previdência Social (assim como a proteção ao direito fundamental à previdência social) é um dever do Estado, na medida em que resvala em interesse legítimo da sociedade que o sustenta. Justamente por não ser delegado ao indivíduo, por si só ou em grupo, promover e conservar um sistema de proteção de tal vulto, cabe ao Estado assumir essa tarefa, principalmente em decorrência dos princípios fundamentais da dignidade humana, da solidariedade e da justiça social. $^{351}$

\footnotetext{
${ }^{348}$ SIMM, op. cit., p. 116-117.

${ }^{349}$ Ibid. (grifos no original)

${ }^{350}$ SIMM, op. cit., p. 117.

${ }^{351}$ SIMM, op. cit., p. 117.
} 
Mesmo porque a própria noção de Previdência Social, decorrente de um direito fundamental social, exige prestações positivas do Estado destinadas à salvaguarda de condições mínimas de sobrevivência digna à pessoa sujeita a uma contingência social. Ao contrário dos direitos fundamentais individuais, a atuação estatal nos direitos sociais não está limitada a uma postura de não interferência, de modo que a atuação efetiva do Estado é medida de garantia da observância imediata dessa modalidade de direitos.

E é justamente a partir desse entendimento que surge a concepção dos direitos subjetivos públicos do cidadão, ou seja, de direitos a certa atuação ou prestação do Poder Público, decorrentes de uma obrigação constitucional do Estado.

Aliás, a questão do dever do Estado em assumir uma postura ativa no que concerne ao direito fundamental à previdência social e, em consequência, à instituição a ele vinculada, inclusive, expressamente manifestada na própria Constituição Federal Brasileira ao estabelecer que a Seguridade Social, compreendendo os direitos relativos à saúde, à previdência e à assistência social, será organizada a partir de um conjunto integrado de ações de iniciativa do próprio Estado (Poderes Públicos) e de toda a sociedade.

A noção de um Estado interveniente nas relações sociais decorre de um postulado de bem estar social, cujo modelo iniciado no início do século XX pode ser observado até os dias atuais, justificando uma postura estatal ativa no sentido de promover ações para a garantia de direitos sociais. No entanto, essa forma de Estado vem atravessando, ao redor do mundo, uma ferrenha crítica, especialmente no que concerne aos direitos e garantias trabalhistas e previdenciários, em razão da globalização e do crescimento do sistema econômico capitalista.

O principal impacto da crise do Estado social pode ser traduzido na incapacidade financeira de prover um sistema de previdência social eficiente e adequado. É por essa razão que constantes reformas têm sido implementadas nos sistemas previdenciários no mundo e no Brasil, de forma a garantir apenas o mínimo necessário às necessidades mais básicas do indivíduo, repassando à iniciativa privada a obrigação de suprir o que mais for necessário para o atingimento de uma vida digna. ${ }^{352}$

${ }^{352}$ SIMM, op. cit., p. 112. 
Essa medida, no entanto, vai de encontro à garantia de proteção do indivíduo em face do risco social, consubstanciada não só pelo direito fundamental social, mas, ainda, pela garantia institucional de um sistema previdenciário. Ao se furtar do dever de garantir a manutenção de uma vida digna aos membros da sociedade que o forma e sustenta, o Estado atinge o núcleo essencial do direito fundamental, promovendo retrocesso social.

Não pode o Estado, sob o argumento de incapacidade financeira, delegar à iniciativa privada o encargo de proteção social, ao menos no que respeita aos seus padrões mínimos. Não se trata de uma atividade lucrativa que possa ser explorada economicamente; antes e ao contrário, é, sim, um dispêndio, um ônus financeiro do Estado como tantos outros, impondo-se o intervencionismo estatal como forma de tornar reais e efetivos os ideias de solidariedade, de bem comum e de justiça social. É inegável, portanto, que a Seguridade Social constitui-se em um dos mais relevantes direitos fundamentais da pessoa humana, em garantia institucional e em dever indelegável do Estado. ${ }^{353}$

${ }^{353}$ SIMM, op. cit., p. 117. 


\section{DA APLICAÇÃO CONCRETA DO PRINCÍPIO DA PROIBIÇÃO DO RETROCESSO SOCIAL NA PREVIDÊNCIA SOCIAL BRASILEIRA}

\subsection{A adequação de hipóteses de reversibilidade do nível de proteção de acordo com o princípio da proibição do retrocesso social}

Durante o desenvolvimento deste trabalho, muito já foi mencionado a respeito da importância da proteção aos direitos humanos fundamentais, principalmente, os de cunho social, essenciais para a garantia da dignidade humana.

Também já foi mencionado que cada direito fundamental tem um núcleo essencial, que lhe dá subsistência e do qual não se pode disponibilizar. Verificou-se, ainda que o objeto da proibição do retrocesso social apresenta-se intimamente vinculado a essa noção, uma vez que se transforma em instrumento de garantia da intangibilidade do núcleo essencial dos direitos fundamentais.

A questão que se enfrenta agora é avaliar se é possível flexibilizar a proteção social, ou seja, que se possa vislumbrar situações, ainda que substanciais, de medidas retrocessivas sem que haja prejuízo à dignidade humana.

Inicialmente, é preciso revisitar algumas colocações anteriormente estabelecidas neste trabalho, a fim de fundamentar as ponderações a serem apresentadas adiante.

Conforme já mencionado anteriormente, o princípio da proibição do retrocesso social não pode ser entendido de forma absoluta. Daí se tratar de princípio e não de regra, na qual a margem de proteção fica imbuída de caráter imutável.

Uma noção de proibição absoluta ao retrocesso social acaba por ir de encontro à possibilidade do legislador de escolher a melhor opção dentre as existentes, de forma discricionária. Impede, ainda, o legislador de promover os ajustes necessários ao atingimento da maior eficácia possível ao direito fundamental social, dentro do limite do que já foi 
conquistado. E mais: desestabiliza o princípio da democracia e atinge frontalmente a noção da reserva do possível. ${ }^{354}$

Portanto, há de se considerar a possibilidade de se permitir uma reversibilidade relativa dos direitos fundamentais. E essa reversibilidade somente pode ser relativamente entendida porque, para produzir efeitos, necessariamente precisa atender a dois requisitos essenciais: o primeiro é o não atingimento do núcleo essencial e do nível de conformação já alcançado e o segundo é o exame da justificativa e proporcionalidade da medida de reversibilidade, já que detém uma presunção de inconstitucionalidade pela própria natureza do direito em debate.

No primeiro momento, conforme também já analisado anteriormente, a aferição da constitucionalidade da medida retrocessiva apresentada é feita com base no núcleo essencial do direito fundamental, que é intransponível e não se sujeita a critérios de ponderação. Assim, se uma medida é considerada ofensiva ao núcleo essencial do direito fundamental, não se faz necessária qualquer outra análise: é cristalinamente retrocessiva e será atingida pela máxima da proteção trazida pelo princípio da proibição do retrocesso social.

Por outro lado, podem-se verificar medidas que apresentem teor de reversibilidade, mas que, após uma análise com base no núcleo essencial do direito fundamental, chega-se à conclusão de que o mesmo não foi atingido, nem o grau de concretização afetado. Essas medidas serão fulminadas pelo princípio da proibição do retrocesso social? Depende.

Depende da aferição do segundo requisito de apuração da possibilidade de reversibilidade do direito fundamental: a avaliação de que tal medida encontra-se justificada e é proporcional ao fim almejado (bem comum). É, portanto, a partir do segundo requisito de aferição de eventuais efeitos retrocessivos de uma medida que se apresenta o juízo de ponderação justificador da designação de princípio ao ideal de proibição de retrocesso social, na medida em que demonstra que o nível de proteção por ele trazido está sujeito a critérios de proporcionalidade.

\footnotetext{
${ }^{354}$ SARLET, Ingo Wolfgang. A Eficácia dos Direitos Fundamentais: uma teoria geral dos direitos fundamentais na perspectiva constitucional. 10. ed. rev., atual. e ampl. Porto Alegre: Livraria do Advogado, 2009. p. 448-450.
} 
Isso porque toda medida que atinge o núcleo essencial é retrocessiva e fulminada pelo princípio da proibição do retrocesso social, mas nem toda medida que apresente caráter de reversibilidade é retrocessiva, uma vez que sujeita à avaliação de atingimento do núcleo essencial e ao juízo de ponderação da justificativa e proporcionalidade da modificação proposta. Não é toda reversibilidade que é proibida porque não é toda alteração que afeta o núcleo essencial ou é arbitrária, discriminatória, ou ofensiva.

Dentro dessa concepção, podem-se descobrir medidas com caráter de reversibilidade que não estão sujeitas ao grau máximo de proteção do princípio da proibição do retrocesso social, primeiro porque não atingem o núcleo essencial do direito e segundo, porque, após o juízo de ponderação, foi verificada sua conformidade com os ditames normativos vigentes e a necessidade de sua efetivação em benefício da sociedade em geral. Apesar do caráter retrocessivo, o princípio da proibição do retrocesso social cede espaço para outros interesses sociais considerados mais relevantes.

Superada a questão do primeiro requisito (respeito ao núcleo essencial do direito fundamental) para apuração da possibilidade da aplicação de uma medida flexibilizadora pelo Legislador dentro de sua liberdade conformadora, resta a avaliação do segundo elemento: a conformação da medida a critérios de adequação e proporcionalidade, com vistas ao afastamento do princípio da proibição do retrocesso social. Para isso, alguns parâmetros devem ser utilizados de modo a auxiliar nessa avaliação: proporcionalidade em sentido amplo ou proibição de proteção deficiente, que engloba aferição de idoneidade ou aptidão da medida, necessidade ou indispensabilidade e proporcionalidade em sentido estrito; igualdade; segurança jurídica e proteção da confiança; e, finalmente, racionalidade da fundamentação da medida. $^{355}$

A questão da proporcionalidade em sentido amplo ou proibição da proteção deficiente deve ser analisada sob a perspectiva de uma adequação dos meios aos fins, afastando-se qualquer medida arbitrária, exagerada ou inadequada. ${ }^{356}$

A identificação da medida com a maior e melhor adequação depende, pois, de critérios de proporcionalidade, de modo a garantir que, ainda que a medida tenha caráter retrocessivo,

\footnotetext{
${ }^{355}$ NETTO, op. cit., p. 199.

${ }^{356}$ Ibid.
} 
seja evitada uma proteção deficiente. Tais critérios são utilizados para se apurar se o afastamento do princípio da proibição do retrocesso social é constitucional e válido.

Considerando a proporcionalidade em sentido amplo, devem ser analisados seus 3 subprincípios: pertinência, aptidão ou adequação - conformidade do meio ao fim perseguido -, necessidade - extensão da medida em conformidade com o fim - e proporcionalidade em sentido estrito utilização dos meios adequados à luz do conjunto de interesses em jogo. Deve-se verificar, por meio desses subprincípios, se a medida retrocessiva é proporcional no sentido de respeitar a proibição da proteção deficiente. ${ }^{357}$

A análise da pertinência, aptidão ou adequação considera, de forma objetiva e comprovada, se a medida em questão é útil para o atingimento do fim buscado. Ou seja, se é efetivamente um meio autêntico para se alcançar o objetivo perseguido. ${ }^{358}$

Sobre esse aspecto de adequação, dois pontos merecem destaque. O primeiro é relativo ao objetivo perseguido: deve ser constitucionalmente legítimo e aceito. O segundo é relativo ao meio escolhido: deve ser, além de idôneo e legítimo, o mais eficaz, rápido e seguro possível. $^{359}$

Deste modo, uma medida idônea, legítima e adequada (no sentido de apta) para o alcance de um objetivo legitimamente aceito pela Constituição conduz ao afastamento de uma proteção deficiente, de forma que, mesmo com reflexos de reversibilidade, já apresenta os primeiros indícios para ser constitucionalmente sustentada.

No que concerne à necessidade da medida, a avaliação encontra-se condicionada à ponderação entre as vantagens e desvantagens da escolha realizada, de modo a garantir que a opção feita seja a menos agressiva possível, isto é, que afete o direito no menor grau possível. ${ }^{360}$

Por fim, o último item de aferição da proporcionalidade em sentido amplo para garantia da observância do princípio da proibição deficiente pode ser traduzido como

\footnotetext{
${ }^{357}$ NETTO, op. cit., p. 202.

358 Ibid., p. 203.

359 "A idoneidade determina que haja uma relação de causalidade positiva entre a medida determinada e o fím perseguido, ou seja, que o meio eleito pelo Legislador facilite à obtenção do fim, havendo, por certo, graus distintos nesta relação, referentemente á eficácia, rapidez e segurança do meio na obtenção ou facilitação da obtenção do fim." (Ibid.).

${ }^{360}$ Ibid., p. 205.
} 
proporcionalidade em sentido estrito. Esse elemento tem como fator principal a questão da justa medida, ou seja, da adequação justificada da escolha do legislador frente à afetação a ser causada na esfera social. ${ }^{361}$

O objetivo desse item de ponderação é, portanto, avaliar se a medida escolhida pelo legislador é suficientemente justificada, considerando as noções de justiça social e dignidade humana, num embate entre a gravidade da restrição e a real fundamentalidade do fim almejado. $^{362}$

Além da proporcionalidade em sentido amplo e do respeito à proibição de proteção deficiente, cuja extensão é avaliada a partir de mecanismos de idoneidade, necessidade e justa adequação, outros critérios também podem (e devem) ser utilizados a fim de se ponderar se a medida de reversibilidade retrocessiva afronta ou não o princípio da proibição do retrocesso social.

Uma medida de caráter retrocessivo, que não atinja o núcleo essencial do direito fundamental, para não ser fulminada pelo princípio da proibição do retrocesso social deve, ainda, ser estabelecida em conformidade com o princípio da igualdade.

Para entendimento desse critério, importante se faz a identificação do tipo de igualdade que se pretende ver observada. Para fins de direitos fundamentais, a igualdade que se busca não é a igualdade meramente formal, estabelecida na Lei Maior e pela qual todos são iguais perante a lei. $\mathrm{O}$ que se busca na proteção dos direitos fundamentais com vistas à dignidade humana é a chamada igualdade fática, material ou substancial, na qual a todos sejam garantidas as mesmas condições de vida, oportunidades e efetiva participação na sociedade.

Dentro dessa concepção de igualdade fática, a medida escolhida pelo legislador não pode, sob qualquer hipótese, ser substancialmente discriminatória, isto é, garantir circunstâncias privilegiadas a certo grupo de pessoas em detrimento do resto da sociedade,

\footnotetext{
${ }^{361}$ NETTO, op. cit., p. 206.

362 "O controle de proporcionalidade em sentido estrito leva a analisar o desvalor do sacrifício que é imposto ao direito social em relação ao valor da satisfação do bem que se persegue. As fases anteriores do controle, referentes à idoneidade e necessidade, centram-se na análise do meio e do fim; nesta fase, o que se faz é valorar as grandezas que estão em relação, ou seja, a precedência estabelecida, a gravidade da restrição sobre determinado direito e a importância das razões que a justificam”. (Ibid.)
} 
salvo se esse situação se justificar pela correção de desigualdades sociais em favor das classes mais necessitadas (análise da justa medida). ${ }^{363}$

Portanto, para que a medida flexibilizadora retrocessiva não se sujeite aos ditames do princípio da proibição do retrocesso social, não pode ter caráter socialmente discriminatório, ou seja, deve-se submeter ao tratamento do princípio da igualdade, materialmente considerado.

\footnotetext{
Neste contexto, percebe-se que o princípio da proibição de retrocesso social não é invocável para perpetuar privilégios, como se disse anteriormente; pelo contrário, deve coadunar-se com a busca pela igualdade material, imposta pelo princípio da sociabilidade, bem como pela dignidade da pessoa humana. Pode haver retrocesso, respeitado o núcleo essencial do direito social e os parâmetros abordados, que seja reclamado pela igualdade material com a alteração de situações de privilégio não justificadas. ${ }^{364}$
}

A questão da segurança jurídica já foi objeto de análise anterior no presente estudo. Trata-se de um mecanismo de proteção à continuidade da ordem jurídica vigente. É um postulado que deriva da noção de Estado de Direito, no qual é garantida uma mínima estabilidade para as normas, de forma a sustentar a proteção da confiança na ordem constitucional em vigência.

Não se limita, portanto, a fundamentar o princípio da proibição do retrocesso social, mas vai além, e se torna critério para aferição da relativização do nível de proteção contra medidas retrocessivas.

Somado à intangibilidade do direito adquirido, da coisa julgada e do ato jurídico perfeito, o critério da segurança jurídica e da proteção da confiança tem como objetivo averiguar se a medida tomada é fundamentada na premissa de boa fé e da manutenção e preservação da ordem jurídica.

Esse critério tem especial importância quando se trata de matérias cujas modificações são recorrentes, como é o caso da Previdência Social. Nesse exemplo, uma medida previdenciária de caráter retrocessivo somente terá o princípio da proibição do retrocesso

\footnotetext{
${ }^{363}$ NETTO, op. cit., p. 208.

364 Ibid., p. 209.
} 
social afastado na hipótese de, além de superados os critérios anteriores, mantiver um mínimo de estabilidade da norma e respeitar os direitos, as expectativas e os interesses legítimos. ${ }^{365}$

Por fim, o último critério de aferição da possibilidade de legitimação de medida de caráter retrocessivo é a racionalidade da fundamentação da opção selecionada.

A criação de toda e qualquer norma deve ser fundamentada por meio de uma argumentação racional e jurídica, com base na exposição dos interesses e valores envolvidos, de forma a possibilitar o controle de sua legitimação. ${ }^{366}$ Com uma norma que apresenta vertentes retrocessivas, essa premissa não seria diferente. Ao contrário, sua fundamentação exige uma racionalidade e uma justificativa muito mais aprofundadas.

Tais normas, em especial em razão de sua natureza, demandam um rigoroso controle material, de modo que sua fundamentação necessariamente deve "demonstrar, de forma racional, sua adequação aos parâmetros materiais plasmados na Constituição - para além da adequação formal - de molde a permitir sua compreensão e controle", 367

Essa obrigação de uma justificativa racional deriva essencialmente da fundamentalidade dos direitos humanos sociais e da subsunção ao princípio da democracia, uma vez que qualquer alteração em direito fundamental para ter eficácia deve ser feita por um representante da sociedade interessada e ter motivos plenamente embasados. ${ }^{368}$

Em suma: a medida de caráter retrocessivo deve ter sua fundamentação facilmente identificada (porém não necessariamente com explicitação formal) e justificada, de forma a permitir o seu controle. Assim, a fundamentalidade racional da medida retrocessiva deve se apresentar apta a responder prontamente a todos os critérios de averiguação de sua viabilidade.

A racionalidade da fundamentação da medida deve, portanto, demonstrar cabalmente se esta não atinge o núcleo essencial do direito fundamental. Ainda, deve comprovar que o meio utilizado é idôneo, legítimo e o mais eficaz, rápido e seguro possível, e que o fim

\footnotetext{
${ }^{365}$ NETTO, op. cit., p. 211.

${ }^{366}$ Ibid., p. 215.

${ }^{367}$ Ibid.

${ }^{368}$ Ibid.
} 
almejado é legitimamente aceito pela Constituição. Não bastasse isso, deve também evidenciar ser necessária e o menos gravosa possível, além de ser a mais justa medida. Por fim, deve esclarecer não ser discriminatório nem ser ofensivo a um mínimo de estabilidade exigido para manter a proteção da confiança no ordenamento jurídico vigente. ${ }^{369}$

Portanto, superada a ofensa ao núcleo essencial dos direitos fundamentais, respeitados os critérios de adequação e proporcionalidade e demonstrada a possibilidade de a medida se apresentar apta a revelar imediata e racionalmente sua fundamentação, considera-se afastado do princípio da proibição do retrocesso social, sendo legitimada uma medida retrocessiva.

Se uma medida formalizada pelo legislador não atingir o conteúdo essencial do direito fundamental social e superar, integralmente, todos os critérios acima estabelecidos, ainda que apresente cunho retrocessivo, não estará sujeita à aplicação do princípio da proibição do retrocesso social. Isso porque além de amplamente justificada, sua efetivação pressupõe-se mais importante e vantajosa aos interesses gerais da sociedade.

\subsection{Da modulação temporal de efeitos no controle de constitucionalidade pela proibição do retrocesso social.}

Perpassada a questão da possibilidade de uma medida retrocessiva não ser atingida pelo princípio da proibição do retrocesso social e, consequentemente, ser considerada constitucional, faz-se necessária uma breve análise da temática envolvendo também a possibilidade (ou não) de modulação dos efeitos da proibição do retrocesso social, a partir do controle de constitucionalidade das normas pelo Poder Judiciário.

\footnotetext{
369 "Com este objetivo, entende-se que a fundamentação racional da medida passa pela possibilidade de demonstração dos seguintes aspectos: a) o retrocesso não esvazia o núcleo essencial do direito social, preservando-se sua eficácia prestacional essencial; b) o fim visado com o retrocesso é fim compatível com a máxima eficácia do sistema de direitos fundamentais e com o sistema constitucional; c) o retrocesso é meio apto a atingir o fim visado; a medida se torna idônea; d) o retrocesso foi determinado em comparação com outras alternativas mais gravosas para o direito social, para o sistema de direitos fundamentais e para o sistema constitucional; a medida resulta necessária; e) o retrocesso foi determinado considerando a intensidade da restrição do direito social relativamente ao favorecimento do bem a que se visa proteger; a medida resulta proporcional; f) o retrocesso não é arbitrário à luz da igualdade; g) o retrocesso se coaduna com a segurança jurídica e com a proteção da confiança, sendo previstas, se for o caso, normas de transição ou compensações indenizatórias; h) o retrocesso foi determinado no bojo de medidas voltadas ao aproveitamento pleno e otimizado dos recursos disponíveis, inserido em políticas públicas adequadas às tarefas constitucionalmente previstas; g) o retrocesso, segundo as normas aplicáveis, conforma-se à participação social na definição de políticas públicas. Estes são os aspectos essenciais que a fundamentação da medida retrocessiva deve ser apta a revelar, demonstrando sua racionalidade e tornando-a compreensível e controlável.” (NETTO, op. cit., p. 215-216).
} 
Partindo-se do pressuposto que uma medida foi declarada inconstitucional, porquanto retrocessiva, uma vez que em que não foi capaz de superar qualquer dos dos critérios acima descritos, há a possibilidade desses efeitos serem modulados, ou seja, ela ser considerada, no todo ou em parte, em algum período de tempo, constitucional?

Para esclarecer essa questão, inicialmente é importante estabelecer o conceito de modulação, seu surgimento e a forma como pode se apresentar. Importa, no entanto, esclarecer que o objetivo dessa análise não é exaurir a matéria de controle de constitucionalidade e seus efeitos, mesmo porque foge do objeto do presente estudo. O escopo dessa avaliação é tão somente entender a implicação da possibilidade de modulação quando se trata de retrocesso social.

Para a estruturação de um Estado Democrático de Direito, no qual são privilegiadas as disposições trazidas por uma Constituição rígida e soberana, todas as situações jurídicas havidas devem se conformar com os preceitos e princípios constitucionais. ${ }^{370}$

Nessa medida, para a guarda da Constituição e a consequente garantia de sua efetividade, uma fiscalização contra as inconstitucionalidades revela-se imprescindível. Essa fiscalização foi tratada pela doutrina contemporânea como controle de constitucionalidade, cuja instauração se deu de modo efetivo por meio de uma construção judicial ocorrida nos Estados Unidos ${ }^{371}$ (caso Marbury x Madison ${ }^{372}$ ). Por esta razão, ao sistema que atribui ao Poder Judiciário o controle de constitucionalidade, convencionou-se chamar sistema americano $^{373}$.

Dentro deste modelo de controle de constitucionalidade, surgem dois critérios para efetivação da supremacia constitucional: o controle difuso, no qual a inconstitucionalidade pode ser declarada por qualquer juiz ou Tribunal, reconhecendo-se o exercício da jurisdição constitucional a todos os componentes do Poder Judiciário, e o controle concentrado, no qual

\footnotetext{
${ }^{370}$ SILVA, José Afonso da. Curso de Direito Constitucional Positivo. 14 ed. rev. e atual. nos termos da Reforma Constitucional. São Paulo: Editora Malheiros, 1997. p. 50.

371 FERREIRA FILHO, Manoel Gonçalves. Princípios Fundamentais de Direito Constitucional. 2. ed. São Paulo: Saraiva, 2010. p. 133-135.

${ }^{372}$ U.S. Supreme Court. 1803.

${ }^{373}$ Em contraposição ao modelo americano, surge, no século XX, na Europa, o chamado sistema europeu (também conhecido como sistema de justiça constitucional), no qual o controle de constitucionalidade é atribuído a um órgão independente do Judiciário. Não se trata, portanto, de um controle judicial.
} 
apenas a um Tribunal Constitucional ou Corte Especial de cúpula do Poder Judiciário é permitido o exercício do controle de constitucionalidade. ${ }^{374}$

No Brasil, a Constituição de 1988 manteve o sistema difuso já previsto em constituições anteriores, além de alargar a abrangência do controle concentrado ${ }^{375}$. O objetivo foi justamente intensificar a defesa da Constituição e demonstrar o papel político deste controle, principalmente pela legitimidade conferida a certos órgãos de cunho político, como os partidos políticos, as confederações sindicais e as entidades de classe. ${ }^{376}$

Deste modo, o ordenamento jurídico brasileiro combina os critérios difuso e concentrado (este de competência do Supremo Tribunal Federal) na proteção aos direitos fundamentais e demais ditames constitucionais.

A questão que surge a partir da necessidade do controle da constitucionalidade das leis à luz da Constituição Federal é acerca dos efeitos do reconhecimento da inconstitucionalidade da norma, se nulo ou anulável.

A teoria da nulidade absoluta dos atos declarados inconstitucionais se origina do mesmo modo que a própria concepção de controle de constitucionalidade: pelo sistema americano. No mesmo julgado Marbury x Madison, ficou constatada a nulidade absoluta de leis que contrariem disposições constitucionais. ${ }^{377}$

A interpretação das Constituições brasileiras, inclusive a atual, defende a teoria da nulidade absoluta, sob a argumentação de que a validade de uma lei ou qualquer outro ato normativo depende de sua consonância com as previsões constitucionais. Os efeitos da declaração de inconstitucionalidade, portanto, revestem-se de efeito ex tunc. No entanto, tal entendimento foi modificado após novos precedentes americanos, sob a justificativa de que,

\footnotetext{
${ }^{374}$ SILVA, op. cit., p. 53.

${ }^{375}$ Art. 103. Podem propor a ação direta de inconstitucionalidade e a ação declaratória de constitucionalidade: I o Presidente da República; II - a Mesa do Senado Federal; III - a Mesa da Câmara dos Deputados; IV - a Mesa de Assembleia Legislativa ou da Câmara Legislativa do Distrito Federal; V - o Governador de Estado ou do Distrito Federal; VI - o Procurador-Geral da República; VII - o Conselho Federal da Ordem dos Advogados do Brasil; VIII - partido político com representação no Congresso Nacional; IX - confederação sindical ou entidade de classe de âmbito nacional.

${ }^{376}$ FERREIRA FILHO, op. cit., p. 145.

${ }^{377}$ Nesse julgado, três paradigmas foram consignados: (i) a Constituição é lei suprema; (ii) a lei que contraria a Constituição é reconhecidamente nula e (iii) o órgão competente para o interpretar a Constituição e declarar a conformação de uma lei é o Poder Judiciário, representado pela Corte Suprema.
} 
em certos casos, a nulidade da medida provocaria graves efeitos sociais e econômicos, que deveriam ser evitados em benefício de uma segurança jurídica.

É nesse contexto que o Supremo Tribunal Federal passa a adotar a possibilidade de se afastar a nulidade absoluta da inconstitucionalidade de norma ${ }^{378}$, estabelecendo efeitos temporais ex nunc ao controle de constitucionalidade, ou seja, válidos apenas a partir da data da decisão. E em decorrência desse entendimento, surge o instituto da modulação temporal de efeitos no controle de constitucionalidade, consubstanciado pelo disposto na Lei 9.868/99, em seu artigo 27, que dispõe:

Art. 27. Ao declarar a inconstitucionalidade de lei ou ato normativo, e tendo em vista razões de segurança jurídica ou de excepcional interesse social, poderá o Supremo Tribunal Federal, por maioria de dois terços de seus membros, restringir os efeitos daquela declaração ou decidir que ela só tenha eficácia a partir de seu trânsito em julgado ou de outro momento que venha a ser fixado.

Assim, pela edição de uma lei que dispõe sobre o processo e o julgamento da ação direta de inconstitucionalidade e da ação declaratória de constitucionalidade perante o Supremo Tribunal Federal, permitiu-se que este Tribunal Superior estabelecesse a partir de qual momento a inconstitucionalidade de determinada medida passaria a vigorar, criando-se,

378 “O dogma da nulidade da lei inconstitucional pertence à tradição do direito brasileiro. A teoria da nulidade tem sido sustentada por importantes constitucionalistas. Fundada na antiga doutrina americana, segundo a qual 'the inconstitutional statute is not law at all', significativa parcela da doutrina brasileira posicionou-se pela equiparação entre inconstitucionalidade e nulidade. Afirmava-se, em favor dessa tese, que o reconhecimento de qualquer efeito a uma lei inconstitucional importaria na suspensão provisória ou parcial da Constituição. Razões de segurança jurídica podem revelar-se, no entanto, aptas a justificar a não-aplicação do princípio da nulidade da lei inconstitucional. Não há negar, ademais, que aceita a ideia da situação 'ainda constitucional', deverá o Tribunal, se tiver que declarar a inconstitucionalidade da norma, em outro momento fazê-lo com eficácia restritiva ou limitada. Em outros termos, o 'apelo ao legislador' e a declaração de inconstitucionalidade com efeitos limitados ou restritos estão intimamente ligados. Afinal, como admitir, para ficarmos no exemplo de Walter Jellinek, a declaração de inconstitucionalidade total com efeitos retroativos de uma lei eleitoral tempos depois da posse dos novos eleitos em um dado Estado? Nesse caso, adota-se a teoria da nulidade e declara-se inconstitucional e ipso jure a lei, com todas as consequências, ainda que dentre elas esteja a eventual acefalia do Estado? Questões semelhantes podem ser suscitadas em torno da inconstitucionalidade de normas orçamentárias. Há de se admitir, também aqui, a aplicação da teoria da nulidade tout court? Dúvida semelhante poderia suscitar o pedido de inconstitucionalidade, formulado anos após a promulgação da lei de organização judiciária que instituiu um número elevado de comarcas, como já se verificou entre nós. Ou, ainda, o caso de declaração de inconstitucionalidade de regime de servidores aplicado por anos sem contestação. Essas questões - e haveria outras igualmente relevantes - parecem suficientes para demonstrar que, sem abandonar a doutrina tradicional da nulidade da lei inconstitucional, é possível e, muitas vezes, inevitável, com base no princípio da segurança jurídica, afastar a incidência do princípio da nulidade em determinadas situações. Não se nega o caráter de princípio constitucional ao princípio da nulidade da lei inconstitucional. Entende-se, porém, que tal princípio não poderá ser aplicado nos casos em que se revelar absolutamente inidôneo para a finalidade perseguida (casos de omissão ou de exclusão de benefício incompatível com o princípio da igualdade), bem como nas hipóteses em que a sua aplicação pudesse trazer danos para o próprio sistema jurídico constitucional (grave ameaça à segurança jurídica)". (Superior Tribunal de Justiça. RE n 364.304 AgR/RJ. Relator Ministro Gilmar Mendes. Ementa publicada no Diário da Justiça em 06 de novembro de 2006. Disponível em < http://www.stj.gov.br>. Acesso em 20 de outubro de 2012). 
assim, uma nova forma de estabelecimento dos efeitos temporais, conhecida como modulação dos efeitos temporais, com o objetivo de garantir a segurança jurídica das relações e a proteção da confiança de que os atos praticados em decorrência da medida permaneçam válidos. $^{379}$

Essa modulação, contudo, está sujeita à análise de dois requisitos: um, de natureza formal, vinculado à aprovação pela maioria absoluta dos membros do Tribunal e o outro, de natureza material, no qual é imprescindível a existência de razões de segurança jurídica ou de excepcional interesse social a justificar a medida. Presentes ambos os requisitos, autoriza-se o Pretório Excelso a prever, para o passado ou para o futuro, os limites da inconstitucionalidade da lei colocada sob análise.

Transportando a noção de modulação dos efeitos do controle de constitucionalidade para as medidas que apresentem caráter retrocessivo, resta analisar se, nessas hipóteses, a inconstitucionalidade reconhecida pode ser limitada no tempo, ou seja, gerar efeitos apenas ex nunc, a exemplo da possibilidade conferida ao Supremo Tribunal Federal.

Para se ofender o princípio da proibição do retrocesso social e, consequentemente, ser declarada inconstitucional, a medida deve deixar de cumprir os critérios estabelecidos no item anterior. Assim, deve atingir o núcleo essencial ou ser incapaz de suprir as exigências de idoneidade, necessidade, justa medida, igualdade, segurança jurídica e racionalidade da fundamentação. E, para que os efeitos de uma declaração de inconstitucionalidade sejam modulados, tem que ser justificado a necessidade de segurança jurídica ou o excepcional interesse social.

Se uma medida de caráter retrocessivo viola o núcleo essencial de um direito fundamental social, ela deve ser imediatamente declarada inconstitucional, sem sequer ser considerada a possibilidade de modulação de seus efeitos. Isso porque, quando uma medida atinge o núcleo essencial de um direito, e, portanto, da própria dignidade humana, não pode haver razão que justifique o interesse social na constitucionalidade da medida. Não há interesse social que ratifique a ofensa ao princípio basilar da dignidade da pessoa humana.

\footnotetext{
${ }^{379} \mathrm{O}$ surgimento da modulação dos efeitos temporais de medidas declaradas inconstitucionais até hoje sofrem ferrenhas críticas, embasadas, primordialmente, pelo repúdio a uma atuação política por parte do Supremo Tribunal Federal (poder normativo), cuja função primordial, ao contrário, é zelar pela correta aplicação da Constituição, sem se submeter a realizar a concretização da mesma.
} 
A modulação dos efeitos temporais pelo argumento da segurança jurídica, por outro lado, também não se justifica nessa caso, uma vez que a própria segurança jurídica é um dos fundamentos da proteção constitucional aos direitos fundamentais. Ainda, não pode haver confiança em um ordenamento jurídico que sustenta medidas retrocessivas que atingem o mínimo básico existencial, em detrimento do bem maior dos direitos humanos e dignidade.

Já no que concerne a medidas retrocessivas que não atingem o núcleo essencial do direito fundamental social, a avaliação da segurança jurídica e do excepcional interesse social deve perpassar os critérios de idoneidade, necessidade, justa medida, igualdade, segurança jurídica e racionalidade da fundamentação para justificar uma modulação dos efeitos.

A partir dessa constatação, questiona-se: é possível uma medida inidônea, desnecessária, injusta, discriminatória, que gere insegurança (aí já até elimina a avaliação da segurança jurídica para a modulação), e, consequentemente, impossível de se fundamentar racionalmente tenha seus efeitos considerados de relevante interesse social a ponto de se permitir uma modulação temporal dos mesmos? Em suma: uma medida cristalinamente prejudicial aos membros da sociedade, porquanto retrocessiva, injustificada à luz da proteção dos direitos fundamentais, tem como apresentar algum interesse social?

Ademais, a própria análise da constitucionalidade ou inconstitucionalidade da medida é feita pela ponderação dos requisitos acima descritos. Para uma medida retrocessiva atingir o princípio da proibição do retrocesso social e ser, em um corolário lógico, considerada inconstitucional, a questão da segurança jurídica e do interesse social já foi objeto de profunda e completa verificação.

Portanto, vislumbra-se que, nada obstante a modulação dos efeitos temporais do controle de constitucionalidade ser uma realidade no ordenamento jurídico brasileiro, sua aplicação não deve ser estendida a medidas retrocessivas de cunho social, uma vez que sob todos os ângulos analisados, não se identifica possibilidade de justificativa para tal procedimento, uma vez que os requisitos que poderiam embasar a sua utilização, elucidados no artigo 27 da Lei 9.868/99, já foram superados e afastados pelo próprio reconhecimento da inconstitucionalidade. 


\subsection{Da análise dos casos práticos}

Face a tudo o que foi exposto até agora no presente estudo, faz-se necessária a visualização prática da aplicação dos critérios acima expostos para a avaliação da constitucionalidade ou inconstitucionalidade de certas medidas aparentemente retrocessivas à luz do princípio da proibição do retrocesso social. Os exemplos trazidos não são necessariamente os que mais renderam discussões doutrinárias e jurisprudenciais quando de sua inclusão no ordenamento jurídico brasileiro, mas servem de modelo para a análise que ora se propõe a título ilustrativo de todas as noções e entendimentos aqui perpassados.

\subsubsection{Fator Previdenciário na aposentadoria por tempo de contribuição}

A aposentadoria é considerada o carro chefe e o principal benefício da Previdência Social Brasileira, seja pelo quantidade de concessões, seja pelo valor envolvido no pagamento desse benefício. Tamanha importância é, inclusive, corroborada pela descrição dos requisitos

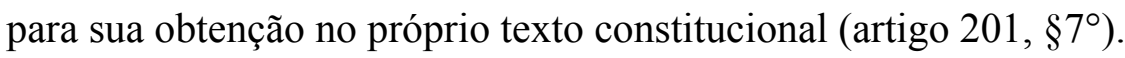

A aposentadoria por tempo de contribuição se traduz na possibilidade do segurado receber um benefício previdenciário em decorrência de ter contribuído por mais de 30 anos (se mulher) e 35 anos (se homem). É a antiga contribuição por tempo de serviço, tendo a nomenclatura (e a forma de apuração do principal requisito - tempo) sido alterada quando da publicação da Emenda Constitucional $n^{\circ}$ 20, alcunhada de Reforma da Previdência, ocorrida em 15 de dezembro de 1998.

Esta Reforma da Previdência, teve como principal objetivo rever alguns critérios para a organização da estrutura previdenciária, bem como estabelecer um novo regime previdenciário geral único no Brasil, de forma a garantir o equilíbrio financeiro e atuarial do sistema, expressão que, inclusive, passou a integrar o caput do artigo 201 da Constituição Federal. Dentro desse objetivo, várias alterações foram propostas e muitas dessas propostas se tornaram efetivas por meio da Emenda Constitucional, como, por exemplo, a eliminação da aposentadoria por tempo de serviço proporcional e a criação de uma regra de transição de forma de garantir a segurança jurídica e a proteção da confiança. 
Outras propostas, que visavam estabelecer novos requisitos para a obtenção do benefício da aposentadoria ordinária, como a integração do critério idade para a concessão do benefício, acabaram por ser afastadas por ocasião da aprovação do projeto da Emenda. Ou seja, não foi aprovada qualquer alteração, por Emenda Constitucional, dos requisitos para a concessão do benefício da aposentadoria por tempo de contribuição.

Em consequência das alterações trazidas pela Emenda Constitucional $n^{\circ}$ 20/98, principalmente com a inserção da expressão "observados critérios que preservem o equilíbrio financeiro e atuarial" e da exclusão do texto constitucional dos critérios de cálculo do valor do benefício (alteração da redação original do artigo 202), que foi delegado à forma da lei, o legislador infraconstitucional decretou uma lei para estabelecer novas condições de apuração dos cálculos dos benefícios.

A Lei $\mathrm{n}^{\circ}$ 9.876, de 26 de novembro de 1999, traz, entre outras previsões, o aumento do período básico de cálculos dos benefícios e a implementação do fator previdenciário para as aposentadorias por tempo de contribuição e por idade, sendo esta última de caráter opcional.

Traduz-se o fator previdenciário em uma fórmula matemática, criada com o objetivo de "equiparar a contribuição do segurado ao valor do benefício" "380 na qual são considerados a alíquota de contribuição, a idade do trabalhador no momento da aposentadoria, o tempo de contribuição à Previdência Social na data do pedido de aposentadoria e a expectativa de sobrevida do segurado, considerada a partir da tábua completa de moralidade desenvolvida pelo IBGE (Fundação Instituto Brasileiro de Geografia e Estatística), considerando-se uma média nacional única para ambos os sexos.

A justificativa para o desenvolvimento desses novos critérios de cálculo do valor dos benefícios, em especial a aposentadoria por tempo de contribuição, foi estimular os trabalhadores a permanecerem no mercado de trabalho, evitando-se aposentadorias precoces que afetam a capacidade financeira do sistema. Por outro lado, conforme firmemente frisado no acórdão ${ }^{381}$ que julgou o pedido liminar de suspensão dos efeitos do artigo $2^{\circ}$ da Lei

\footnotetext{
${ }^{380}$ Conforme descrição trazida pelo site da Previdência Social. Disponível em $<$ http://www.previdencia.gov.br $>$. Acesso em 20 de outubro de 2012.

381 Acórdão proferido na ADI 2111/DF, em 16 de março de 2000, de relatoria do Ministro Sidney Sanches, negando pedido de liminar de suspensão da eficácia do artigo $2^{\circ}$ da Lei $n^{\circ}$ 9.876/99, que estabeleceu novos critérios de apuração do cálculo do valor dos benefícios de aposentadoria por idade e por tempo de contribuição,
} 
9.876/99, face à sua inconstitucionalidade formal e material, tal alteração é embasada pela própria redação do caput do artigo 201 da Constituição, refletindo um cálculo atuarial com vistas a um equilíbrio no sistema.

Nada obstante o julgado acima, até a presente data o Supremo Tribunal Federal não proferiu sentença definitiva sobre a constitucionalidade (ou inconstitucionalidade) do fator previdenciário instituído pelo artigo $2^{\circ}$ da Lei 9.876/99, fato que tem gerado bastante discussão na doutrina e acarretado decisões divergentes na jurisprudência. Há, inclusive, em andamento, Projeto de Lei do Senado (PLS 296/2003) com vistas à extinção do fator previdenciário, que atualmente encontra-se pendente de votação da Câmara dos Deputados.

À parte dos argumentos lançados para justificar a inconstitucionalidade do fator previdenciário, é possível embasar esse argumento também por ofensa ao princípio da proibição do retrocesso social? É essa análise que proceder-se-á neste tópico do trabalho, a partir dos critérios acima descritos.

O primeiro requisito para a avaliação da retrocessão de uma medida, é avaliar se ela atinge o núcleo essencial de um direito fundamental. Conforme verificado anteriormente, caso haja ofensa ao mínimo básico garantido por um direito, a medida torna-se indiscutivelmente atingida pela proibição do retrocesso social. No caso do fator previdenciário, urge a avaliação de sua ofensa ao conteúdo essencial do direito fundamental à previdência social.

A circunstância de ter sido inserida no ordenamento jurídico uma nova forma de cálculo do benefício da aposentadoria especial inviabilizou ou limitou a garantia do direito à previdência social e aos benefícios previdenciários em prol da proteção ao trabalhador em caso de necessidade? O direito à proteção social trazida pela garantia de um sistema previdenciário foi violado pela nova forma de cálculo do benefício?

sob a fundamentação de que (i) não se vislumbra inconstitucionalidade formal pela ausência de demonstração do não cumprimento do previsto no artigo 65, §único da Constituição Federal, e (ii) não se vislumbra inconstitucionalidade material porquanto a medida encontra-se embasada no artigo 201 da Lei Maior (garantia do equilíbrio financeiro e atuarial do sistema, na forma da lei. Voto divergente do Ministro Marco Aurélio de Mello, que entendeu pelo deferimento da suspensão dos efeitos do artigo $2^{\circ}$ da Lei $n^{\circ} 9.876 / 99$, argumentando que o fator previdenciário equivale à criação de um novo requisito para a concessão do benefício da aposentadoria por tempo de contribuição (idade), o que não foi admitido pela Constituição Federal. (Supremo Tribunal Federal. Ação Direta de Inconstitucionalidade n 2111/DF. Relator Ministro Sidney Sanches. Ementa publicada no Diário da Justiça em 05 de dezembro de 2003. Disponível em <http://www.stf.gov.br>. Acesso em 20 de outubro de 2012). 
A resposta para essas perguntas é não. Mesmo com a alteração da forma de cálculo, o segurado da Previdência Social continua mantendo seus direitos intactos e o objetivo da proteção social previdenciária não restou maculado. Não foram criados novos requisitos, em detrimento dos já previstos no texto constitucional, ou sequer foi eliminado o direito ao benefício constitucionalmente garantido para suprir eventuais necessidades do indivíduo a fim de assegurar uma vida digna.

Portanto, no que concerne ao primeiro requisito para apuração da inconstitucionalidade do fator previdenciário, à luz do princípio da proibição do retrocesso social, este não pode ser considerado retrocessivo.

Porém, para a verificação da inconstitucionalidade em razão da proibição do retrocesso, não basta a análise da afronta ao núcleo essencial, nada obstante sua imprescindível avaliação. Faz-se também necessária, na sequência, a verificação dos demais requisitos, sob o critério da ponderação.

O primeiro critério de ponderação apura se o fator previdenciário está adstrito ao princípio da proibição da proteção deficiente a partir da avaliação proporcional da existência de medida idônea, necessária e justa.

Por primeiro, é necessário avaliar se a medida é útil para a consecução do fim, ou seja, se é constitucionalmente legítimo e aceito. O objetivo do fator previdenciário é garantir o equilíbrio financeiro e atuarial do sistema, evitando que o trabalhador passe mais tempo recebendo o benefício da aposentadoria do que contribuindo para o sistema. Nessa medida, tendo respaldo constitucional para sua existência e sendo meio facilitador à garantia do fim almejado, de forma eficaz, rápida e segura, o fator previdenciário pode ser considerado apto para atender ao comando constitucional. Deste modo, sob o aspecto da idoneidade, não pode ser considerado retrocessivo.

Por segundo, cabe ponderar se a medida é necessária. Ou seja, se o fator previdenciário é a medida mais benigna (ou, pelo menos, menos desvantajosa) para o objetivo almejado. Sob esse aspecto, no entanto, o fator previdenciário padece de justificativa razoável. Se o fim desejado pelo legislador constitucional é estimular os trabalhadores a 
permanecerem no mercado de trabalho mais tempo a fim de sustentar o equilíbrio financeiro e atuarial no sistema, certamente a redução do valor do benefício não é a medida menos agressiva para a consecução do escopo buscado, principalmente com vistas à proibição de uma proteção deficiente. Obviamente que, um valor reduzido de benefício previdenciário em razão dos critérios de idade e expectativa de sobrevida, mesmo tendo o segurado cumprido todos os requisitos exigidos pela Lei Maior, não podem ser considerados uma proteção social efetiva, principalmente. Portanto, sob o aspecto da necessidade, o fator previdenciário é considerado retrocessivo.

Por terceiro, deve ser realizada a verificação da justa medida da afetação proposta, isto é, se o sacrifício proposto é justificado considerando a satisfação que se busca alcançar, se a gravidade da medida é válida face às razões que a sustentam. Já se afirmou que o fim almejado é o equilíbrio financeiro e atuarial do sistema, pelo incentivo à permanência ativa no trabalho por mais tempo. O sacrifício é a concessão de aposentadoria em valor menor do que o segurado teria direito, porquanto embasada em critérios anteriormente não considerados (idade e expectativa de sobrevida). Justifica-se a garantia de um sistema equilibrado pela redução do poder aquisitivo do trabalhador que cumpriu integralmente todos os requisitos exigidos pela Constituição? Perfaz-se uma ideia de justiça social restringir o nível de sustento do segurado a partir de critérios jamais anteriormente mencionados? Remontando-se ao critério anterior, não existe outra forma mais suave de se atingir esse objetivo? Não é possível incentivar a permanência do trabalhador no mercado de trabalho de outras formas menos prejudiciais e mais dignas ao seu sustento e de sua família?

Portanto, a implementação do fator previdenciário, que reduz o poder aquisitivo do segurado por um critério não previsto constitucionalmente não pode ser considerada uma medida adequada e justa com o propósito de garantir uma proteção eficaz. A proteção, nesse caso, se torna altamente deficiente. Sob este aspecto, também o fator previdenciário se revela uma medida retrocessiva.

Outro critério que merece apuração é a questão da igualdade material da medida, no sentido de não se revelar discriminatória. No que tange ao fator previdenciário, é possível afirmar que estabelecer critérios de cálculo do valor da aposentadoria a partir da idade e da expectativa de sobrevida é estabelecer indicativo de diferenciação prejudicial àqueles que, por circunstâncias de vida, necessitam começar a trabalhar em idades mais tenras. Isso significa 
que o fator previdenciário acaba por privilegiar os membros de classes mais abastadas, que podem iniciar sua atividade laborativa após a devida formação profissional. Em outras palavras, as pessoas de classe mais baixa, cuja única alternativa para enfrentar a pobreza é iniciar o trabalho o mais cedo possível, serão prejudicadas pela regra de "quanto menos idade, menor o valor da aposentadoria", na medida em que precisarão trabalhar mais para obter o mesmo valor de aposentadoria que outro indivíduo que pôde se dedicar à sua formação antes de exercer qualquer labor. Claramente configurada uma postura discriminatória totalmente injustificada, de modo que o fator previdenciário, por mais uma vez, se apresenta retrocessivo.

Ainda, com relação à análise de segurança jurídica e proteção da confiança, também não se justifica a constitucionalidade do fator previdenciário. A Constituição Federal, apesar de buscar o equilíbrio financeiro e atuarial do sistema, garante expressamente que os requisitos para obtenção de uma aposentadoria por tempo de contribuição com proventos integrais, restringe-se ao cumprimento do prazo estabelecido em seu texto. Ou seja, nenhum outro critério foi previsto para obstar a obtenção de tal benefício. No entanto, uma lei infraconstitucional estabelece uma fórmula de redução do valor da aposentadoria com base na idade e na expectativa de sobrevida do segurado, contrariando (ou, no mínimo, ignorando) um expresso posicionamento constitucional. O reconhecimento dessa medida como justa e constitucional leva ao entendimento de que a Constituição não tem poder suficiente para fazer valer suas disposições, gerando insegurança na relação entre Estado e sociedade e quebrando a confiança institucional. Mais uma razão se apresenta para demonstrar o retrocesso social trazido pela configuração da fórmula mirabolante do fator previdenciário.

Por fim, o fator previdenciário para não ser considerado medida retrocessiva à luz do princípio da proibição do retrocesso social, deve ser racionalmente fundado e proporcionalmente justificado. ${ }^{382}$ A partir dos critérios anteriores, é possível perceber que o fator previdenciário não se justifica, na medida em que dispensável, agressivo, materialmente desigual e sem garantir qualquer segurança jurídica ao sistema. Inverossímil qualquer fundamentação racional para uma medida retrocessiva desse porte que se apresenta prejudicial ao indivíduo sem, por outro lado, representar um benefício compreensível e controlável pelo Estado. $^{383}$

\footnotetext{
${ }^{382}$ NETTO, op. cit., p. 215.

${ }^{383}$ Ibid., p. 217.
} 
Portanto, face a todo o exposto, nada obstante se tratar o fator previdenciário de medida que não atinge o núcleo essencial do direito fundamental à previdência social e se considerar uma medida idônea à consecução do fim constitucional almejado, sua existência se revela desnecessária, injusta, discriminatória, insegura juridicamente, gerando desconfiança no ordenamento jurídico vigente. Restando impossibilitada uma fundamentação racional para sua manutenção, configura-se medida retrocessiva que atinge frontalmente o princípio da proibição do retrocesso social. Indiscutivelmente, o fator previdenciário é uma medida inconstitucional, a despeito da posição inicial trazida liminarmente pelo Supremo Tribunal Federal.

\subsubsection{A qualificação do garimpeiro no Regime Geral de Previdência Social brasileiro}

Quando da organização de um sistema previdenciário apto a garantir a observância do direito fundamental a uma proteção em caso de necessidade, o legislador constitucional estabeleceu que todos os trabalhadores que exercerem atividade remunerada seriam necessariamente qualificados como segurados, mediante a respectiva contribuição compulsória, de forma a estarem amparados em caso de impossibilidade de manter seu sustento e de sua família. Aliás, a própria noção de Previdência Social surgiu embasada na impossibilidade de se exercer atividade laborativa, sendo, posteriormente, estendida, de forma facultativa, aos demais indivíduos que não trabalham.

Assim, no decorrer dos anos, e culminado com a Constituição Federal de 1988 e a criação de normas regulamentadoras de um Regime Geral de Previdência Social no Brasil, toda e qualquer modalidade de trabalhador está sujeita à contribuição e, consequentemente, acobertada pela proteção previdenciária.

Pela organização do sistema, os segurados da Previdência Social brasileira estão divididos em dois grandes grupos: os de natureza obrigatória, cuja filiação ao sistema é compulsória e que abarca a totalidade dos indivíduos que exercem alguma atividade laborativa e recebem alguma contraprestação remuneratória; e os de natureza facultativa, cuja filiação ao sistema, como o próprio nome diz, é opcional, reunindo como membros os indivíduos que não são classificados como obrigatórios, tendo, portanto, extensão residual. 
Os segurados obrigatórios, por sua vez, se subdividem em várias classificações, cada uma com sua forma de contribuição previdenciária e de cálculo do valor do benefício. Atualmente, a divisão dos segurados obrigatórios segue a seguinte divisão: empregados, empregados domésticos, contribuintes individuais, trabalhadores avulsos e segurados especiais, de acordo com os critérios e as definições trazidas pelas Leis $n^{\circ} 8.212$ e 8.213, editadas em 24 de julho de 1991 e que tratam, respectivamente, do custeio e dos benefícios da Previdência Social brasileira.

Os critérios para a classificação dos segurados obrigatórios foram sendo alterados ao longo dos anos por diversas leis ordinárias sucessivas. ${ }^{384} \mathrm{Um}$ dos exemplos de trabalhador cuja função foi objeto do maior número de alterações legislativas, inclusive constitucional, foi o garimpeiro, razão pela qual foi a escolha para a verificação da inconstitucionalidade da sua última alteração classificatória.

Atividade de garimpo (executada pelo trabalhador alcunhado de garimpeiro) é uma forma de extração mineral com sinais de existência desde o século XV, quando desenvolveuse na busca por riquezas minerais. Caracteriza-se pela exploração de substâncias, tais como, ouro, diamantes, quartzo, ametista, entre outros tipos de minérios. É um tipo de atividade desenvolvida a céu aberto, de poucos recursos e equipamentos simples e rústicos. ${ }^{385}$

Por se tratar de uma atividade desenvolvida primordialmente no campo, a função de garimpeiro foi originalmente classificada como segurado especial. ${ }^{386}$

Segurado especial é a modalidade de segurado obrigatório da Previdência Social que se caracteriza pelo trabalho de pequeno porte doméstico no âmbito rural e pelo sistema de economia familiar, no qual todos os membros de uma família convergem seus esforços para a economia de consumo do grupo familiar, objetivando a sobrevivência de todos. A

\footnotetext{
${ }^{384}$ Leis $^{\circ}{ }^{8} 8.540 / 92 ; 9.528 / 97 ; 9.876 / 99 ; 10.403 / 2002 ; 11.718 / 2008$.

385 "O trabalho individual de quem utiliza instrumentos rudimentares, aparelhos manuais ou máquinas simples e portáteis, na extração de pedras preciosas, semipreciosas e minerais metálicos ou não metálicos, valiosos, em depósitos de eluvião ou aluvião, nos álveos de cursos d'água ou nas margens reservadas, bem como nos depósitos secundários ou chapadas (grupiaras), vertentes e altos de morros, depósitos esses genericamente denominados garimpos". (Artigo 70 do Decreto-Lei n 227/67 - Código de Mineração)

386 "Como segurado especial: o produtor, o parceiro, o meeiro e o arrendatário rurais, o garimpeiro, o pescador artesanal e o assemelhado, que exerçam suas atividades, individualmente ou em regime de economia familiar, ainda que com o auxílio eventual de terceiros, bem como seus respectivos cônjuges ou companheiros, e filhos maiores de 14 (quatorze) anos ou a eles equiparados, desde de que trabalhem, comprovadamente, com o grupo familiar respectivo." (Artigo 11, VII, Lei n ${ }^{\circ} 8.213 / 91$ e Artigo 12, VII, Lei nº 8.212/91).
} 
classificação de um trabalhador como segurado especial garante a proteção previdenciária a todos os membros pertencentes ao regime de economia familiar, com base em uma única forma de contribuição, incidente sobre a receita bruta da produção havida.

A proteção a essa modalidade de trabalhador é tamanha, principalmente em razão da simplicidade e da rusticidade da atividade, além da necessidade de uma proteção específica para a economia de subsistência, que é a única qualificação de segurado da Previdência Social que está expressamente estabelecida no texto constitucional.

Assim, a redação original da Constituição Federal de 1988 previa, em seu artigo 195, parágrafo $8^{\circ 387}$, que a função de garimpeiro era considerada como segurado especial, para fins de recolhimento da contribuição previdenciária, requisitos para concessão de benefícios e seus respectivos cálculos de valores. Esta determinação foi fielmente seguida quando da implementação das leis regulamentadoras do custeio e dos benefícios da Previdência Social, em 1991.

Em total repúdio às determinações constitucionais, as Leis $n^{\circ}$ 8.398/92 e 9.528/97 já trouxeram em seu bojo a alteração da classificação securitária do trabalhador exercente da atividade de garimpo. Pela redação das mencionadas leis, essa modalidade de trabalhador, nada obstante a disposição constitucional, já não mais seria enquadrado como segurado especial, aproveitando os benefícios dessa tipificação. A definição da atividade foi equiparada a autônomo, sujeitando-se às regras de custeio e de benefícios estabelecidas para essa classificação de segurado.

A Reforma da Previdência, introduzida pela Emenda Constitucional $n^{\circ}$ 20, de 15 de dezembro de 1998, revolucionou o sistema previdenciário até então existente, alterando previsões, estruturas e métodos de organização e manutenção do sistema, aproveitando, também para regularizar questões controversas, como era o caso da classificação securitária do garimpeiro.

\footnotetext{
387 “O produtor, o parceiro, o meeiro e o arrendatário rurais, o garimpeiro e o pescador artesanal, bem como os respectivos cônjuges, que exerçam suas atividades em regime de economia familiar, sem empregados permanentes, contribuirão para a seguridade social mediante a aplicação de uma alíquota sobre o resultado da comercialização da produção e farão jus aos benefícios nos termos da lei."
} 
Portanto, a redação do artigo 195 , parágrafo $8^{\circ}$ foi alterada com o objetivo de excluir da classificação de segurado especial a atividade de garimpeiro, mantendo, todavia, sua identificação como trabalhador rural, garantindo-lhe a redução do tempo de contribuição para aposentadoria. Com base na alteração do texto constitucional, a Lei $n^{\circ}$ 9.876/99, regulamentadora da Reforma Constitucional da Emenda $n^{\circ} 20 / 98$, categorizou o garimpeiro como segurado obrigatório da Previdência Social, na modalidade de contribuinte individual, que veio a substituir a antiga nomenclatura de autônomo e equiparado a autônomo.

$\mathrm{Na}$ prática, entre outras vantagens, o garimpeiro perdeu a possibilidade de realizar a contribuição previdenciária baseada no valor da produção obtida, sem necessidade de comprovação do efetivo recolhimento, e o aproveitamento da condição de segurado para todo o grupo familiar que contribui para o desenvolvimento da atividade. Nesse aspecto, trata-se de medida claramente retrocessiva, haja vista que prejudicial ao trabalhador garimpeiro. Resta analisar se a medida retrocessiva pode ser considerada inconstitucional à luz do princípio da proibição do retrocesso social.

Conforme já visto, o primeiro aspecto a ser analisado é com relação à ofensa direta ao núcleo essencial do direito fundamental à proteção previdenciária. No que concerne a esta apuração, a alteração da classificação da modalidade de segurado para o trabalhador garimpeiro (de segurado especial para segurado contribuinte individual) não afetou o direito à proteção social em caso de necessidade, sendo-lhe mantidos, em sua totalidade, os benefícios e serviços garantidos a todos os segurados da Previdência Social, mediante contribuição compulsória. Logo, esta medida, apesar de prejudicial ao trabalhador e, nessa condição, considerada retrocessiva, não pode ser qualificada como inconstitucional com base na inobservância do conteúdo essencial do direito fundamental à previdência social.

Superada a avaliação do núcleo essencial, faz-se necessária a análise proporcional da medida adotada para verificação, dentro de certos critérios adotados, de sua adequação e justiça no ordenamento jurídico brasileiro.

O primeiro critério é a idoneidade ou aptidão da medida. Para essa investigação, é necessário, inicialmente identificar o fim desejado pelo legislador, a fim de estabelecer um liame de causalidade e utilidade entre o meio escolhido e o objetivo perquirido. Qual o objetivo da Emenda Constitucional $n^{\circ} 20 / 98$ e de sua consequente norma regulamentadora 
para alterar a classificação securitária do trabalhador garimpeiro? E mais, qual benefício essa alteração poderia trazer à sociedade de forma a justificar sua realização? Por fim, se identificado, esse objetivo é legítimo?

Pode-se num primeiro momento, tentar justificar a medida pelo objetivo de atingir o equilíbrio financeiro e atuarial do sistema, garantindo uma participação financeira mais efetiva dos trabalhadores do garimpo. Porém, esse argumento cai por terra se analisarmos que a alteração da classificação securitária do garimpeiro, nada obstante desconforme, é anterior à Reforma Constitucional que deu origem à necessidade de visão atuarial do sistema.

Ainda, pode-se buscar a justificativa da medida pelo objetivo de corrigir privilégios desarrazoados, como a equiparação do garimpeiro ao pequeno produtor rural de uma economia de subsistência. No entanto, essa argumentação do mesmo modo não convence, já que sua atividade, apesar de extrativa (e não produtiva) também é realizada de forma bem simplificada e rústica, muitas vezes por membros da mesma família, com vistas a garantir a subsistência de todo o grupo. A exemplo de qualquer produção rural, também é uma atividade exauriente, realizada a despeito das intempéries da natureza, sem qualquer auxílio de empregados (mesmo porque sem condições de ter) e com o objetivo de sustento. Ademais, não se justifica excluir a extração mineral realizada pelo pequeno trabalhador se a extração vegetal e a extração animal (pesca) foram mantidas como objeto de proteção especial.

Em suma, nada há que justifique a medida adotada. Não há objetivos racionalmente definidos que legitimem e justifiquem a exclusão do garimpeiro do rol de atividades passíveis de classificar os trabalhadores como segurados especiais. Assim, diante da ausência de um objetivo racionalmente definido que justifique a medida retrocessiva adotada, resta prejudicada a análise da idoneidade da medida. Da mesma forma, impossível verificar se a escolha do legislador é indispensável e se é justa, uma vez que ambas as ponderações consideram a relação entre o meio escolhido e o fim almejado. Se o próprio fim não está claramente resolvido, não se pode avaliar se o meio perpetrado encontra-se justificado. A medida claramente perfaz uma proteção deficiente, à luz da máxima eficácia protetiva dos direitos sociais, ao trabalhador garimpeiro.

Por outro lado, na esteira do defendido acima, não se pode buscar realizar medidas retrocessivas com o objetivo de corrigir distorções que sequer existem. É sabido que o critério 
da igualdade permite a utilização de medidas retrocessivas com vistas a evitar a perpetuação de privilégios não razoáveis. Contudo, esse não é o caso da medida ora em análise. Não há privilégio na equiparação do garimpeiro e demais pequenos mineradores ao trabalhador rural voltado à exploração vegetal e animal, de modo que não há regalias a serem extirpadas do sistema em prol de uma igualdade material. A medida retrocessiva que excluiu o garimpeiro do rol de segurados especiais é, portanto, discriminatória em sentido inverso, porquanto tenta eliminar um privilégio inexistente e, como consequência, acaba por expor tais trabalhadores a uma situação de desigualdade material.

Com relação à avaliação do critério de segurança jurídica e conformação com a proteção da confiança, melhor sorte não ampara a medida retrocessiva analisada. Uma medida injustificada e injusta não pode se coadunar com um ordenamento jurídico inspirador de confiança e garantidor de segurança para a sociedade. O reflexo da manutenção dessa medida, principalmente sem um objetivo claro e definido, gera uma instabilidade da previsão normativa, cuja falta de transparência do fim almejado e do interesse público vinculado, leva ao questionamento da efetiva existência de um Estado de Direito.

Por fim, pela impossibilidade de qualquer justificativa que demonstre a aptidão, indispensabilidade, justiça, defesa da igualdade material e garantia da segurança jurídica da medida retrocessiva que excluiu o garimpeiro do rol de segurados especiais, agravado pela ausência de um objetivo claro, definido e transparente, não há qualquer fundamentação racional que ampare a adequação da medida, a despeito de sua característica retrocessiva.

Deste modo, muito embora não atinja o núcleo essencial do direito fundamental à previdência social, tal posicionamento revela-se prejudicial ao trabalhador garimpeiro e inadequado aos interesses gerais da sociedade, de modo que não se valida à luz do princípio da proibição do retrocesso social. Tal medida deve, portanto, ser coberta pelo manto da inconstitucionalidade.

\subsubsection{Proteção constitucional ao acidente de trabalho}

A preocupação com o trabalhador, nada obstante ser o labor uma tarefa existente desde o primórdio dos tempos, somente ganhou espaço a partir da Revolução Industrial, cujo modelo econômico desencadeia o surgimento de uma degradação ambiental natural e humana 
jamais antes vista. Os trabalhadores da época (proletariado) estavam sujeitos à ausência de qualidade de vida em razão da constância das doenças ocupacionais e dos acidentes de trabalho.

O Direito do Trabalho surge, portanto, para promover a proteção da vida e da saúde dos trabalhadores, através de normas que buscavam melhorar tanto as condições de trabalho como o meio ambiente em que este trabalho era desenvolvido.

Assim, as condições socioambientais da época, bem como o processo de produção econômica da Revolução Industrial, justificaram o surgimento de uma legislação que hoje é destinada à melhoria da qualidade de vida do trabalhador em seu ambiente de trabalho, compreendendo uma reflexão sobre a integridade do corpo do ser humano dentro dos processos de produção do sistema econômico capitalista. ${ }^{388}$

As reivindicações dos trabalhadores levaram a conferência da Paz de 1919, da Sociedade das Nações, a criar, pelo Tratado de Versailles, a Organização Internacional do Trabalho (OIT), com o objetivo de uniformizar o tratamento das questões trabalhistas, fundamentadas na justiça social. E já na primeira reunião da OIT, ainda no ano de 1919, foram adotadas seis convenções (sobre jornada de trabalho, desemprego, proteção à maternidade, idade mínima para admissão de crianças e trabalho noturno das mulheres e dos menores), cujo objetivo visível era a proteção à saúde e à integridade física dos trabalhadores.

Diante dessa evolução, denota-se a busca por novas soluções jurídicas para a proteção da saúde, incolumidade física e mental e até da vida dos trabalhadores. Baseado nesses princípios, o ordenamento jurídico brasileiro foi construído como um reflexo dessa interminável procura, na medida em que a redação da última Constituição, em uma análise sistemática, leva ao entendimento de que o homem sempre deverá ser priorizado em face de seu trabalho, ou seja, deverá ser realizada uma adaptação da estrutura do trabalho ao ser humano.

\footnotetext{
${ }^{388}$ FIGUEIREDO, Guilherme José Purvin de. Direito Ambiental e a Saúde dos Trabalhadores. 2. ed. São Paulo: LTr, 2007. p. 31.
} 
Assim, a questão da proteção ao trabalho surge como fundamento da República Federativa do Brasil, pelo reconhecimento de seu valor social, demonstrando a importância do trabalho para o homem, não só como fonte de subsistência, mas, principalmente, como meio de inclusão social e de garantia da sua dignidade.

Como se não bastasse, quanto trata da ordem econômica, a Carta Magna de 1988 também retoma sua posição inicial de priorizar o trabalho do homem à luz dos ideais de justiça social. Embora eminentemente capitalista, a ordem econômica prioriza os valores do trabalho humano, inclusive no que concerne ao respeito e proteção ao meio ambiente laboral, sobre todos os demais valores da economia de mercado, o que requer a intervenção do Estado na defesa desses primados.

Na esteira desse entendimento, a questão do acidente do trabalho também foi objeto de proteção específica. O primeiro diploma legal a dar uma orientação geral sobre o tema foi o Código Comercial de 1850, ao garantir ao trabalhador a manutenção dos salários por três meses contínuos em caso de acidentes ocorridos no ambiente laboral, desde que imprevistos e sem culpados. Em 1919, surge a primeira lei tratando do acidente de trabalho, adotando a teoria do risco profissional, decorrente da atividade profissional exercida pelo trabalhador, afastando a análise da culpabilidade. Todavia, somente com a Constituição de 1934 o acidente de trabalho foi considerado prestação previdenciária, através de seguro de natureza privada. ${ }^{389}$ Porém, em 1967 foi editada a Lei $n^{0}$ 5.316, de 14 de setembro de 1967, que, vislumbrando a deficiência da proteção pelo seguro de acidente, determinou sua estatização, vinculando ao Estado a responsabilidade pelo controle e gestão também dessa prestação.

Define-se acidente do trabalho toda e qualquer lesão corporal ou perturbação funcional (doença ocupacional) ocorrida em decorrência, ou no exercício, de atividade laborativa, que cause a morte ou a perda ou redução, permanente ou temporária, da capacidade para o trabalho, de modo a dificultar, ou até inviabilizar, o sustento do trabalhador e de sua família. Nesse contexto, havendo exposição a uma contingência social que impossibilite a garantia da subsistência de um indivíduo, tem-se a descrição do objeto do direito fundamental à previdência social, abraçado pela Constituição Federal de 1988.

\footnotetext{
${ }^{389}$ MARTINS, Sérgio Pinto. Direito da Seguridade Social. 27. ed. São Paulo: Atlas, 2009. p. 399-401.
} 
Assim, a redação original da Carta Magna inseriu o acidente do trabalho como risco social, passível de proteção previdenciária estatal. ${ }^{390}$ Essa escolha do legislador constitucional corroborou a importância da proteção ao trabalhador em sua completa integridade e da valorização do trabalho como meio de se afastar a marginalização e atingir a dignidade humana, em total conformidade com as demais disposições constitucionais sobre o tema.

A despeito desse postura constitucional, a Emenda Constitucional $n^{\circ} 20 / 98$, que realizou a reforma do sistema previdenciário então vigente, alterou a redação do artigo 201 da Constituição, excluindo o acidente do trabalho do rol de contingências sociais atendidas pela Previdência Social, relegando a cobertura do risco acidente do trabalho a um regime concorrente entre a Previdência Social e o setor privado. ${ }^{391}$

Em suma, a Emenda Constitucional excluiu a cobertura da contingência social acidente do trabalho do atendimento previdenciário exclusivo do Estado, determinando sua realização de forma concorrente com o setor privado, em um retorno a um sistema anteriormente aplicado e que não surtiu efeitos positivos.

Na prática, essa medida permite que a Previdência Social deixe de estender suas prestações aos casos de acidente do trabalho/doença ocupacional que incapacitem os trabalhadores para a realização de atividade laborativa e, consequentemente, manutenção de sua subsistência, sob a alegação de que tal proteção deve ser feita por meio de um seguro privado a ser fornecido pelo empregador. Diante de eventual inadimplência do empregador nesse âmbito, o trabalhador fica, portanto, completamente desamparado em uma situação de flagrante necessidade.

\footnotetext{
390 “Art. 201. Os planos de previdência social, mediante contribuição, atenderão, nos termos da lei, a: I - cobertura dos eventos de doença, invalidez, morte, incluídos os resultantes de acidentes do trabalho, velhice e reclusão; [...]"

391 “Art. 201. A previdência social será organizada sob a forma de regime geral, de caráter contributivo e de filiação obrigatória, observados critérios que preservem o equilíbrio financeiro e atuarial, e atenderá, nos termos da lei, a:

I - cobertura dos eventos de doença, invalidez, morte e idade avançada;

II - proteção à maternidade, especialmente à gestante;

III - proteção ao trabalhador em situação de desemprego involuntário;

IV - salário-família e auxílio-reclusão para os dependentes dos segurados de baixa renda;

$\mathrm{V}$ - pensão por morte do segurado, homem ou mulher, ao cônjuge ou companheiro e dependentes, observado o disposto no $\S 2^{\circ} .[\ldots]$

$\S 10$. Lei disciplinará a cobertura do risco de acidente do trabalho, a ser atendida concorrentemente pelo regime geral de previdência social e pelo setor privado."
} 
Cristalino retrocesso configura-se demonstrado, na medida em que contrário aos objetivos de uma proteção previdenciária eficiente garantida por um direito fundamental, consubstanciado pela promoção da justiça social e da dignidade da pessoa humana. Resta analisar se tal retrocesso perfaz-se inconstitucional à luz do princípio da proibição do retrocesso social ou se sua aplicação encontra-se em conformidade com os interesses sociais, justificando sua manutenção.

Conforme já defendido em outras passagens desse estudo, o núcleo essencial de um direito fundamental é o mínimo básico de garantia da efetividade de tal direito. Assim, o núcleo essencial do direito fundamental à previdência social é a garantia da proteção social em caso de situações de necessidade que impeçam o indivíduo de prover seu próprio sustento e de sua família, assegurando-lhe, deste modo, uma vida digna.

Um trabalhador que sofra acidente do trabalho e fique impossibilitado, ainda que temporariamente, de exercer sua atividade laborativa, indiscutivelmente, encontra-se em uma situação de necessidade, posto que, sem seu trabalho, poderá ser relegado à marginalização social. A ausência de qualquer proteção social nesse caso atinge frontalmente o direito fundamental a uma previdência social.

Por outro lado, não houve disposição no sentido de retirar totalmente da esfera de garantia a proteção previdenciária em razão de acidente do trabalho, ao menos por enquanto. Muito embora a cobertura a acidentes do trabalho não faça mais parte do rol principal de descrição de contingências sociais a demandarem proteção social, a Constituição ainda manteve um resquício de cobertura, ainda que concorrente com o setor privado. Portanto, um mínimo básico de efetividade do direito foi mantido, não havendo o que se falar em ofensa ao núcleo essencial do direito fundamental. Sob esse aspecto, não há inconstitucionalidade.

Apesar de não atingir o núcleo essencial do direito fundamental, o retrocesso em comento ainda não está isento de ser considerado inconstitucional. Outro grupo de critérios deve ser preenchido para amparar constitucionalmente a alteração promovida pela Emenda Constitucional $n^{\circ}$ 20/98. A primeira análise a ser efetivada considera a adequação entre o meio escolhido e o fim almejado, a partir de uma visão de proibição de proteção deficiente. Essa análise é realizada com o auxílio de três "medidores": aptidão, necessidade e justa medida. 
Na hipótese em comento, o fim almejado pelo legislador infraconstitucional é claro: reduzir os custos das prestações previdenciárias de cunho acidentário, com o fim de atingir o equilíbrio financeiro e atuarial do sistema, constitucionalmente determinado. O meio utilizado foi justamente dividir a responsabilidade com quem aufere vantagens pela realização do trabalho e que, pela atividade proposta, pode submeter o trabalhador ao risco do acidente: o empregador.

O primeiro "medidor" é a idoneidade ou aptidão, que avalia a adequação ou utilidade da medida escolhida em prol do objetivo traçado. Sob esse aspecto, deve-se ponderar se a divisão das responsabilidades entre Previdência Social e empregador para manutenção de uma proteção em caso de acidente do trabalho se coaduna com a busca pelo equilíbrio financeiro e atuarial do sistema.

A resposta é positiva, uma vez que, além de o fim objetivado ser legítimo, porquanto constitucionalmente previsto, o meio elegido revela-se rápido, eficaz, seguro e, consequentemente, facilitador para atender ao comando constitucional. Assim, o atendimento não exclusivo do acidente do trabalho pela Previdência Social revela-se apto ao atingimento do equilíbrio financeiro e atuarial do sistema, de modo que, sob o aspecto da idoneidade, não pode ser considerado retrocessivo.

O segundo método de análise utiliza o critério da necessidade. Para essa avaliação, verificam-se se as vantagens e desvantagens da medida escolhida, devendo-se sempre optar pela menos agressiva ao direito fundamental.

A busca pelo equilíbrio financeiro e atuarial do sistema previdenciário foi o objeto principal de toda da Reforma da Previdência realizada pela Emenda Constitucional n ${ }^{\circ}$ 20/98. Diversos fatores contribuíram para a necessidade de rever a forma pela qual o sistema previdenciário vinha sendo gerido até então: desde fatores naturais, como o envelhecimento da população até fatores econômicos, como o crescimento de uma estrutura mundial globalizada. Em razão dessa nova realidade, várias medidas foram tomadas com vistas, principalmente, a reduzir o gasto com prestações previdenciárias. 
Assim como no fator previdenciário, a divisão da responsabilidade na proteção social em caso de acidente de trabalho, não encontra justificativa plausível. Como pode ser considerada uma medida menos agressiva sujeitar o trabalhador a uma proteção em caso de acidente de trabalho realizada pelo setor privado, se esta escolha já foi feita anteriormente e teve sua estrutura modificada justamente porque a proteção mínima exigida não foi devidamente realizada? Como pode ser apresentada como necessária (ou até indispensável) uma medida que já se sabe de antemão que não deu certo por experiência própria, na medida em que trazia uma proteção deficiente? Portanto, sob o aspecto da necessidade/indispensabilidade, a medida ora em análise é considerada retrocessiva.

O último "medidor" da proibição da proteção deficiente é a análise da justa medida da afetação escolhida. Essa verificação baseia-se na ponderação entre a gravidade do sacrifício proposto com vistas a sustentar a satisfação do objetivo almejado. $\mathrm{O}$ sacrifício que aqui se apresenta é a disposição das prestações acidentárias ao setor privado (ainda que concorrentemente com a Previdência Social). Ou seja, a redução da proteção ao acidente do trabalho pela Previdência Social para que possa ser também suprida pelo setor privado. Pode ser considerada justa uma medida que visa delegar a proteção social previdenciária ao setor privado, no qual os desequilíbrios econômicos podem ser sentidos com mais frequência e em maior grau, sujeitando os trabalhadores, além do próprio risco social em si, às flutuações mercadológicas? Como considerar justa uma medida (e justificado um sacrifício) que delega à classe trabalhadora o risco de suportar as dificuldades econômicas a que a iniciativa privada normalmente se encontra adstrita, principalmente em um momento que o trabalhador mais necessita de amparo eficiente para suportar os infortúnios laborais?

Por outro lado, a Constituição Federal estabelece a obrigatoriedade da proteção ao meio ambiente de trabalho acima de todos os valores da economia de mercado. Para garantia desse primado, a intervenção do Estado é medida premente. Assim, como justificar a delegação da responsabilidade pela proteção ao acidente de trabalho se a própria Constituição entende pela necessidade de intervenção estatal na garantia da proteção ao ambiente laboral?

Certamente outras medidas menos gravosas para a garantia do equilíbrio financeiro e atuarial do sistema podem ser identificadas. Mesmo porque, se até a presente data não foi regulamentada essa responsabilidade concorrente entre o Estado e a iniciativa privada, situação que pode ser indício da própria inviabilidade da medida. 
Portanto, a implementação da responsabilidade concorrente entre Previdência Social e setor privado para garantia da proteção previdenciária em caso de acidente do trabalho sujeita o trabalhador em situação de necessidade aos desígnios da iniciativa privada, que pode, por exemplo, limitar seu campo de atuação ou impor prêmios muito elevados para financiar o seguro em áreas com muitos acidentes, o que pode inviabilizar a prestação acidentária. ${ }^{392} \mathrm{~A}$ proteção nessas hipóteses, se tornaria altamente deficiente, podendo, inclusive, tornar-se inexistente, de modo que tal medida reveste-se de caráter claramente retrocessivo.

Ainda, para apuração do caráter retrocessivo de uma medida a ponto de torná-la inconstitucional, deve-se analisar se a mesma respeita a igualdade material constitucionalmente prevista, no sentido de não se apresentar discriminatória. Sob esse aspecto, a questão do atendimento concorrente das prestações acidentárias revela sua faceta mais retrocessiva.

Isso porque ao relegar ao setor privado à cobertura do risco de acidente do trabalho, perde o Estado o controle da forma de efetivação dessa proteção, que poderá apresentar-se diferenciada para cada setor da economia, por exemplo, em razão dos investimentos e do retorno de cada área. Conforme mencionado alhures, poderão as empresas seguradoras estabelecer critérios diferenciados para fornecimento de prestações acidentárias em razão da frequência dos acidentes ou até mesmo a partir dos investimentos de cada empresa na prevenção de acidentes. Com isso, as necessidades dos acidentados não serão atendidas de forma uniforme, configurando atuação prestacional injustificadamente discriminatória, o que retira qualquer legitimidade da medida retrocessiva.

Com relação à análise de segurança jurídica e proteção da confiança, também não se justifica o atendimento concorrente da cobertura do risco de acidente do trabalho. A exemplo do que já foi mencionado, ao dividir a responsabilidade da proteção social com a iniciativa privada, perde o Estado parte do controle sobre a atuação da proteção, podendo esta ser realizada conforme a possibilidade e o interesse das empresas seguradoras. Deste modo, a previsibilidade e a estabilidade das ações restarão prejudicadas, abalando a segurança jurídica e a confiança nas relações entre particulares e entre estes e o Estado, sempre que o mesmo não

${ }^{392}$ MARTINS, op. cit., p. 405. 
se apresentar capaz de controlar a atuação do setor privado. Por mais esta razão, a alteração da forma de proteção acidentária trazida pela Emenda Constitucional n ${ }^{\circ}$ 20/98 submete-se ao princípio da proibição do retrocesso social.

Diante da impossibilidade de subsunção aos critérios acima destacados em prol uma justificativa proporcional e racional da intervenção perpetrada no direito social face ao resultado final desejado, não há o que fundamente a manutenção dessa medida flagrantemente retrocessiva. A opção do legislador infraconstitucional de utilizar a cobertura concorrente para o acidente do trabalho como forma de reduzir custos e, assim, garantir o equilíbrio financeiro e atuarial do sistema previdenciário não se adequa racionalmente aos parâmetros constitucionais de proteção aos direitos fundamentais sociais, em especial os de caráter laboral e previdenciário, com vistas à garantia da dignidade humana.

Sendo, portanto, uma medida desnecessária, agressiva, sacrificadora da justiça social, discriminatória e instável, porquanto sujeita aos interesses e possibilidades da iniciativa privada, configura-se imprópria uma fundamentação racional para sua manutenção, atingindo frontalmente o princípio da proibição do retrocesso social e, consequentemente, devendo ser declarada inconstitucional.

\subsubsection{Auxílio Reclusão - concessão do benefício}

O benefício previdenciário do auxílio reclusão foi instituído no ordenamento jurídico brasileiro pelo Decreto $\mathrm{n}^{\circ} 22.872 / 33$ que regulamentou o Instituto de Aposentadoria e Pensões dos Marítimos. Posteriormente, foi regulamentado pelo Decreto $n^{\circ} 24.615 / 34$, que criou o Instituto de Aposentadorias e Pensões dos Bancários até ser consolidado como benefício previdenciário garantido a todos os trabalhadores pela Lei Orgânica da Previdência Social (Lei $\left.{ }^{\circ} 3.807 / 60\right)$.

Contudo, nada obstante sua previsão legal desde a década de 1930, este benefício apenas atingiu status de garantia constitucional com a Constituição Federal de 1988, que, em sua redação original, incluiu a contingência social reclusão em seu rol de riscos sociais 
amparados pelo sistema de Previdência Social, assegurando a proteção social a todos os segurados do regime. ${ }^{393}$

Define-se auxílio-reclusão como um benefício do sistema de Previdência Social (portanto, sujeito à contribuição) destinado a garantir o sustento dos dependentes do segurado recolhido à prisão, de forma a atender às necessidades básicas e essenciais da família enquanto desprotegida e desamparada com a perda da fonte de subsistência do núcleo familiar, pela ausência de seu provedor.

Objetiva, portanto, tal benefício amparar a família, em atendimento ao comando constitucional que garante especial proteção estatal a este instituto, considerado a base da sociedade ${ }^{394}$. Assim, representa a garantia de condições mínimas de vida digna ao ente familiar do segurado recluso, que, na falta de sua principal fonte de renda, fica desamparado e relegado à marginalização social. Por outro lado, ainda viabiliza a realização da previsão constitucional do artigo $5^{\circ}, \mathrm{XLV}$, da Lei Maior, assegurando que nenhuma pena passará da pessoa do condenado, garantindo que seus dependentes não sejam submetidos a condições precárias de subsistência em consequência dos delitos de seu provedor.

A proteção da contingência reclusão, e consequentemente, a concessão de prestação previdenciária do auxílio reclusão, não encontra apoio em grande parte da doutrina brasileira, que sustenta se tratar de uma contingência provocada, de modo que não pode ser considerada risco social. ${ }^{395}$ No entanto, a ideia da defesa desse risco social não é premiar o segurado recluso, mas tão somente garantir a subsistência da família do segurado preso, que, como visto, não pode ser responsabilizada pelos erros de seu membro provedor, substituindo temporariamente o meio de sustento com vistas à manutenção dignidade humana e a erradicação da pobreza, princípios fundantes de um sistema de proteção social.

\footnotetext{
393 “Art. 201. Os planos de previdência social, mediante contribuição, atenderão, nos termos da lei, a: I - cobertura dos eventos de doença, invalidez, morte, incluídos os resultantes de acidentes do trabalho, velhice e reclusão; $[\ldots]$ ”. (g.n.)

394 "Art.226. A família, base da sociedade, tem especial proteção do Estado."

${ }^{395}$ Dentre os que recriminam a concessão do auxílio reclusão, o mais ferrenho defensor é o professor Sergio Pinto Martins que defende: "eis um benefício que deveria ser extinto, pois não é possível que a pessoa fique presa e a sociedade como um todo tenha que pagar um beneficio à família do preso, como se este tivesse falecido. De certa forma, o preso é que deveria pagar por estar nessa condição, principalmente por roubo, furto, tráfico, estupro, homicídio, etc. Na verdade, vem a ser um benefício de contingência provocada, razão pela qual não deveria ser pago, pois o preso dá causa, com seu ato, em estar nessa condição. Logo, não deveria a Previdência Social ter que pagar tal benefício. Lembre-se que, se o acidente do trabalho é provocado pelo trabalhador, este não faz jus ao beneficio. O que mesmo deveria ocorrer aqui." (MARTINS, op. cit., p. 388)
} 
Sob outro aspecto, apesar de a reclusão poder ser considerada uma contingência provocada, na medida em que não condicionada a infortúnios, mas sim, a uma ação predeterminada do segurado, este deve fazer jus ao benefício dela decorrente pela simples razão de que contribui para tanto (a Previdência Social é eminentemente contributiva). Ou seja, o segurado participa ativamente do sistema previdenciário de forma a ser protegido caso esteja submetido a alguma condição (provocada ou não) que lhe impeça de prover o próprio sustento ou de sua família.

Em total arrepio à proteção constitucional, a Emenda Constitucional $n^{\circ}$ 20/98, responsável pela maior alteração já vista no sistema previdenciário brasileiro desde a promulgação da Constituição Federal de 1988, alterou a previsão constitucional de proteção ao risco social reclusão, limitando-o aos segurados de baixa renda, ${ }^{396}$ assim considerados aqueles cujo valor da renda mensal bruta não ultrapassa os limites estabelecidos pela Administração Pública para tal condição ${ }^{397}$. A justificativa para tal medida foi o atendimento ao princípio da seletividade e distributividade na prestação dos benefícios e serviços, regente do Sistema de Seguridade Social Brasileiro, a fim de estabelecer as prioridades de atendimento com vistas à distribuição de renda em prol da redução das desigualdades sociais.

Essa limitação à concessão do benefício do auxílio-reclusão apresenta-se indiscutivelmente retrocessiva, porquanto reduz o contingente de pessoas a fazerem jus ao recebimento da prestação previdenciária. Porém, pode ser considerada inconstitucional à luz do princípio da proibição do retrocesso social? Essa é a análise que será realizada a seguir.

O primeiro ponto de verificação da constitucionalidade (ou inconstitucionalidade) de uma medida retrocessiva é se a mesma atinge o núcleo essencial do direito fundamental. Caso

\footnotetext{
396 “Art. 201. A previdência social será organizada sob a forma de regime geral, de caráter contributivo e de filiação obrigatória, observados critérios que preservem o equilíbrio financeiro e atuarial, e atenderá, nos termos da lei, a:

I - cobertura dos eventos de doença, invalidez, morte e idade avançada;

II - proteção à maternidade, especialmente à gestante;

III - proteção ao trabalhador em situação de desemprego involuntário;

IV - salário-família e auxílio-reclusão para os dependentes dos segurados de baixa renda; [...]” (g.n.)

${ }^{397}$ Atualmente, pela Portaria Interministerial MPS/MF $n^{\circ}$ 02, de 06/01/2012, são considerados de baixa renda os segurados cujo valor do salário de contribuição (calculado sobre a renda mensal bruta) não ultrapassa o montante de $\mathrm{R} \$ 915,05$.
} 
atinja, a medida está imediatamente eivada de inconstitucionalidade, prescindindo qualquer ponderação sobre a necessidade ou adequação da mesma.

No que concerne à limitação do benefício ao auxílio reclusão aos segurados de baixa renda, essa medida não atinge o núcleo essencial do direito fundamental à previdência social. Isso porque o benefício sequer deixou de existir, mas apenas tornou-se restrito ao grupo prioritário de proteção, com base na própria finalidade do sistema previdenciário de promover a distribuição de renda e a erradicação da pobreza. Deste modo, sob o aspecto da afetação ao núcleo essencial, a medida retrocessiva não pode ser considerada inconstitucional.

Superada conformação com a barreira intransponível do direito fundamental, outros critérios devem ser averiguados para diagnosticar se a medida, ainda que retrocessiva, pode ser mantida no ordenamento jurídico, posto que não ofensiva ao princípio da proibição do retrocesso social.

Para analisar a consonância com o princípio da proibição da proteção deficiente, a ponderação dos critérios de aptidão, necessidade e justa medida torna-se imprescindível.

Entende-se por apta ou idônea a medida que se apresente objetivamente útil para o atingimento do fim perseguido, que, por sua vez, deve ser constitucionalmente legítimo. $\mathrm{Na}$ presente circunstância, o objetivo almejado pela medida de caráter retrocessivo confunde-se com o que justifica o próprio sistema previdenciário: realizar a distribuição de renda, priorizando o atendimento aos mais necessitados, a partir de critérios de seletividade e distributividade. Totalmente legítimo, portanto.

O outro requisito é que a medida revele-se útil para a consecução do objetivo, isto é, seja o mecanismo facilitador o mais eficiente, rápido e seguro possível para se atingir o fim apresentado. Sob essa ótica, a medida retrocessiva em comento, de uma forma meramente objetiva, é adequada (idônea) ao objetivo proposto, uma vez que auxilia na promoção da distribuição de renda e na erradicação da pobreza, fins absoluta e constitucionalmente legítimos.

Necessária ou indispensável é a medida que, além de idônea, apresenta-se de forma menos gravosa possível ao direito fundamental que se visa proteger. O objetivo aqui é analisar 
a relação entre as vantagens e as desvantagens da aplicação da medida retrocessiva, justificando-a a partir de convicção de que sua escolha é a melhor possível dentro das opções disponíveis.

Contudo, com relação a esse critério, a limitação da concessão do benefício apenas a segurados de baixa renda não pode ser identificada como a escolha menos agressiva. Sobre essa questão, um ponto merece destaque: a diferença entre priorizar e limitar. Priorizar significa tratar de algo em primeiro lugar, com mais empenho. ${ }^{398}$ Limitar significa restringir, conter, não ir além. ${ }^{399}$ O objetivo, portanto, da seguridade social, como um todo, e da previdência social, em particular, é priorizar o atendimento aos mais necessitados, colocandoos em primeiro lugar, empenhando-se em lhes garantir melhores condições de vida. Mas isso não significa retirar determinado benefício da esfera de disponibilização dos demais segurados. Estabelecer critérios de prioridade no atendimento, por exemplo, é bem menos excessivo do que simplesmente extirpar a concessão do benefício para aqueles que não se enquadrem no ideal de situação de necessidade assumido como indispensável para a obtenção de uma proteção social.

$\mathrm{Na}$ balança de apuração entre vantagens e desvantagens da medida com o objetivo de avaliar sua necessidade, tem-se, portanto, a distribuição de renda para aqueles que auferem baixa renda versus o total desamparado da família de um segurado levado à prisão para aqueles que auferem quantia superior à considerada baixa renda, independentemente da diferença havida entre a efetiva remuneração e o teto limite da baixa renda. Nessa perspectiva, amplamente desnecessária e desproporcional a medida retrocessiva que inviabiliza a concessão do beneficio do auxílio reclusão a todos os segurados da Previdência Social porquanto geradora de uma proteção previdenciária inadequada e deficiente. No que tange ao aspecto da necessidade, revela-se uma medida retrocessiva inconstitucional.

Outro ponto para avaliação da inconstitucionalidade de uma medida retrocessiva é a justa medida da mesma, isto é, se a relação entre a escolha realizada e a afetação por ela causada é adequada e realizada em respeito aos ideais de justiça social.

\footnotetext{
${ }^{398}$ HOUAISS, op. cit., p. 604.

${ }^{399}$ Ibid., p. 463.
} 
Assim, pode ser considerada justa medida promover a proteção de apenas certo grupo de pessoas, em decorrência da presunção de baixa renda, e submeter todo o resto do contingente social à situação de penúria face à ausência de um benefício que substitua os rendimentos do provedor da família, quando levado à prisão, a fim de garantir a subsistência de seus familiares? Pode ser considerada medida adequada e justa a delimitação taxativa de uma faixa de renda, a cargo da discricionariedade da Administração Pública, na qual se baseia para presumir os níveis de necessidade da população, a fim de deferir ou não a concessão de um benefício previdenciário? É ideal de justiça social sacrificar a dignidade de um grupo de pessoas, relegando-as à marginalização social em decorrência da ausência de proteção previdenciária, com vistas a justamente promover a distribuição de renda? E o pior: como justificar que o objetivo da medida é a erradicação da pobreza se a própria garantia de condições dignas de vida está sendo limitada à proteção de apenas um grupo de pessoas?

Nessa esteira de raciocínio, não há qualquer adequação ou justiça na limitação do direito à proteção social pelo benefício do auxílio reclusão, de modo que a medida retrocessiva reveste-se de inconstitucionalidade.

No que tange ao aspecto da igualdade material a ser obrigatoriamente observada pela medida retrocessiva, a limitação do auxílio reclusão revela contornos extremamente discriminatórios.

Isso porque nada há que ampare a diferenciação apresentada pelo legislador, haja vista que o benefício é destinado à família do segurado, que, diante de sua prisão, encontrar-se-á em situação de necessidade face à ausência de seu provedor. Sob esse aspecto, todas as famílias de segurado preso e impossibilitado de prover o sustento da família encontram-se exatamente na mesma condição de penúria. A questão do valor da remuneração do segurado, portanto, não tem qualquer relevância para o cumprimento do objetivo do benefício do auxílio reclusão que é justamente substituir a fonte de renda anteriormente provida pelo segurado levado à prisão.

Assim, nada obstante a baixa renda ser característica do segurado, para fins de concessão do benefício do auxílio reclusão, a situação de necessidade indicada pelo risco social é a da família que, independentemente da renda do segurado, após a prisão deste, ficará 
sem qualquer fonte de renda, tornando-se, consequentemente, sujeita à maior proteção possível a fim de ter sua dignidade garantida.

A retirada de um benefício da esfera de disponibilidade de um grupo de segurados a partir de uma taxativa e indiscriminada delimitação da faixa de renda, que sequer reflete a realidade que a família estará sujeita pela privação de sua fonte de renda originária, não parece ser uma medida que respeite os ideais de igualdade material. Em termos práticos, significa que se o trabalhador auferir apenas um centavo de real a mais do que o teto limitador do que é considerado baixa renda, terá perdido o direito a um benefício que visa primordialmente a garantia de subsistência de sua família. Essa medida torna-se discriminatória na medida em que inviabiliza toda e qualquer proteção previdenciária àqueles que se encontrem fora do âmbito da baixa renda, mesmo estando suas famílias em clara situação de necessidade pela ausência de qualquer fonte de renda.

Nem sequer vale a comparação do auxílio reclusão com o salário família, também concedido a segurados de baixa renda, para justificar o respeito ao princípio da isonomia da medida. Além de o salário família ser concedido ao segurado, ele tem caráter complementar de renda, de modo que justificada sua concessão apenas àqueles que têm a renda considerada inferior. No caso do auxílio reclusão, seu objetivo é substituir a renda do provedor da família, que encontra-se preso e incapacitado de garantir a subsistência de sua família. Nesse contexto, todas as famílias encontram-se em idêntica situação de necessidade, porquanto tiveram suas fontes de sustento suspensas em sua integralidade.

Deste modo, também sob o aspecto da igualdade material, a medida que restringiu o auxílio reclusão aos segurados de baixa renda não se justifica, uma vez que estabelece critérios discriminatórios para concessão do benefício, devendo ser considerada inconstitucional.

Além de não responder satisfatoriamente às ponderações acima realizadas, a presente medida retrocessiva, do mesmo modo, revela-se incapaz de suprir a necessidade de segurança jurídica, com vistas à proteção da confiança no ordenamento jurídico. Para cumprimento desse critério, a medida escolhida deve ser dotada de previsibilidade e de estabilidade, de forma a garantir um mínimo de precisão da norma. 
No caso em análise, a limitação da concessão do benefício do auxílio reclusão teve como parâmetro a identificação dos segurados de baixa renda. Porém, a Emenda Constitucional $n^{\circ}$ 20/98 não estabeleceu os critérios de aferição desse parâmetro. Assim, a definição das faixas de renda, inclusive do limite da baixa renda, ficou a cargo do arbítrio do administrador público, que, dentro de seu poder discricionário, pode modificar as regras dessa definição a qualquer tempo.

E é justamente nesse aspecto que a segurança jurídica resta mais abalada: a limitação do âmbito de concessão do benefício se instrumentaliza diante da vontade do legislador ordinário, atingindo a confiança que deve permear a relação entre o Estado e a sociedade. Deste modo, a escolha pela concessão do benefício do auxílio reclusão apenas para segurados de baixa renda afeta a garantia de uma segurança jurídica, sendo cristalinamente inconstitucional.

Por fim, diante da impossibilidade de se sustentar necessária, justa, materialmente igual, segura e inspirar confiança dentro do sistema jurídico, não há fundamento racional para a manutenção da limitação do auxílio reclusão apenas para segurados de baixa renda. Essa medida revela seu caráter inconstitucional à luz do princípio da proibição do retrocesso social, devendo ser imediata e totalmente retirada do ordenamento jurídico brasileiro.

Diante de tudo o quanto foi exposto, observa-se que o sistema previdenciário brasileiro está sempre sujeito a uma infinidade de modificações legislativas na busca pela garantia de sua saúde financeira. Várias dessas modificações são realizadas sem qualquer estudo prévio da adequação das medidas a serem implementadas, principalmente com vistas à proteção constitucional ao direito fundamental à previdência social, razão pela qual acabam por ser fulminadas pela inconstitucionalidade.

É importante, portanto, que, para cada proposta de implementação de novas alternativas, seja feita uma análise séria e minuciosa do impacto de eventual medida de caráter retrocessivo, de forma a apurar se suas disposições não afrontam, em primeiro lugar, o núcleo essencial do direito fundamental e, em segundo lugar, as ponderações de proibição de proteção deficiente, igualdade, segurança jurídica e racionalidade, sob pena ser declarada inconstitucional pela inobservância do princípio da proibição do retrocesso social. 


\section{CONCLUSÕES}

Diante de todas as considerações apresentadas no decorrer deste estudo, com vistas a analisar do direito fundamental à Previdência Social no ordenamento jurídico brasileiro sob prisma de sua importância como direito inerente ao ser humano na busca pela sua dignidade e à luz do princípio da proibição do retrocesso social, passa-se às seguintes conclusões abaixo consolidadas.

O estudo e a determinação sobre direitos humanos repousam no entendimento de que sua definição (e até sua própria existência) é dependente da razão e da emoção. A questão dos direitos humanos sustenta-se, pois, em uma predisposição com relação ao outro, em uma visão internalizada de empatia, de reconhecimento como semelhante. O surgimento de regras gerais e uniformes, escritas e não escritas, de organização do grupo de pessoas, reforçou o entendimento de que os homens possuem uma igualdade essencial. Diante da unidade do ser humano e de sua consequente dignidade, todos são possuidores de direitos inatos e iguais, indistintamente. A partir dessa perspectiva, incabível desvincular a concepção de ser humano como pessoa humana.

Superada a questão da definição do ser humano como pessoa humana, a partir da noção de autonomia e individualidade, nasce a necessidade de se terem os direitos inerentes a esta condição também observados e protegidos.

O surgimento dos direitos humanos fundamentais ocorreu com a fusão de várias fontes, desde tradições arraigadas nas diversas civilizações até a conjugação de pensamentos filosófico-jurídicos, das idéias advindas do cristianismo e com o direito natural. Todas essas fontes culminavam em um ponto em comum: a necessidade de limitação e controle dos abusos do poder do Estado e de suas autoridades constituídas, além da consagração dos princípios básicos da igualdade e da legalidade como regentes do Estado moderno e contemporâneo.

A noção de direitos fundamentais consagrou a necessidade de se esculpir um rol mínimo de direitos humanos em um documento escrito, colocando-se como uma das previsões obrigatórias a todas as Constituições, no sentido de promover o respeito à dignidade 
humana, garantir a limitação do poder e visar ao pleno desenvolvimento da personalidade humana.

A importância das normas de direitos fundamentais decorre da existência de uma Constituição com força normativa, base fundamentadora de um ordenamento jurídico. Isso significa que as normas de direitos fundamentais somente terão eficácia se a Constituição que as estabelecer sintetizar uma realidade concreta de seu tempo e se as tarefas por ela impostas refletirem a vontade (consciência geral) de concretizar uma ordem jurídica.

Os direitos fundamentais são constitucionalmente definidos a partir de princípios, que são mandamentos de otimização que exigem que algo seja realizado da melhor maneira possível diante das condições jurídicas e fáticas existentes. Assim, a extensão do âmbito de proteção dos direitos fundamentais, como reflexo da amplitude das necessidades humanas, leva a uma consequente colisão desses direitos entre si e com outros interesses constitucionais e a redução dos mesmos em determinadas situações concretas.

Nessa medida, a ideia do núcleo essencial surge como último limite de garantia contra leis e medidas excessivamente restritivas aos direitos fundamentais. Ou seja, trata-se de uma tentativa de delimitar o mínimo de direito fundamental necessário para a manutenção do princípio maior da dignidade humana.

De acordo com a teoria absoluta (ou interna), a definição dos limites dos direitos (fundamentais ou não) é inerente ao próprio direito. Ou seja, os limites de um direito são limites imanentes, fixados por um processo interno, sem qualquer influência ou determinação de aspectos externos. Nessa medida, afasta-se a concepção de colisões com outros direitos.

A teoria relativa (ou externa), ao contrário da anterior, na qual o direito e seus respectivos limites são vistos como uma unidade, divide esse objeto em duas partes: o direito propriamente dito (em si) e, à parte desse direito, suas restrições. Nesse sentido, as restrições aos direitos fundamentais não atingem o conteúdo do direito em si, mas tão somente afetam o exercício de tais direitos. Deste modo, nessa hipótese, pode-se sustentar uma colisão de direitos, vigendo, em cada situação concreta, aquele que reflete, de forma mais aguda, a proteção à dignidade humana. 
A Constituição Federal de 1988 foi a primeira constituição brasileira a elencar a prevalência dos direitos humanos, como princípio fundamental a reger o Estado brasileiro. É, portanto, a primeira constituição brasileira a consagrar um universo de princípios a reger o Brasil no que concerne à questão dos direitos humanos.

Porém, apesar da ideia de núcleo essencial dos direitos fundamentais já vigorar na dogmática jurídico-constitucional em vários países, o ordenamento jurídico brasileiro não adotou, em sua Lei Maior, expressa previsão nesse sentido. Aliás, a Constituição brasileira de 1988 sequer previu a regra da proporcionalidade, deixando a cargo dos Tribunais a utilização dessa sistemática com base no princípio do devido processo legal, em uma acepção de limite ao Legislativo.

Por se tratar a Constituição brasileira de carta com cunho eminentemente protecionista e compromissário, é possível (e imperativo) adaptar a acepção do conteúdo essencial dos direitos fundamentais prevista na Constituição alemã ao direito brasileiro, de forma não só a garantir uma efetiva proteção dos direitos fundamentais (individuais ou sociais) face a eventuais ofensas e excessos, mas também a estabelecer condutas positivas tendentes a trazer eficácia aos direitos lá delimitados.

Um dos maiores problemas enfrentados na proteção dos direitos humanos, entretanto, é justamente estabelecer o ponto que separa o limite máximo de relativização da afetação da essência daquele direito considerado fundamental. E essa identificação é a chave para a manutenção do catálogo constitucional de direitos humanos fundamentais e sua aplicabilidade.

Uma solução para a questão da consignação da linha fronteiriça entre o ponto máximo de relativização do direito fundamental e a afetação de sua essência ou até mesmo sua total aniquilação é a acolhida da teoria do núcleo essencial intransponível dos direitos humanos fundamentais, à luz do que estabelece a Constituição alemã.

Em posição contrária à comumente defendida, pode-se estabelecer que a determinação do núcleo essencial de um direito fundamental não é determinada pela ponderação com outros direitos fundamentais, mas identificada a partir de uma área intransponível e indispensável para a caracterização do próprio direito fundamental a que se condiciona. 
Contudo, nada obstante a aceitação de um conteúdo essencial de cada direito fundamental, não há qualquer indicação dogmática do aspecto nuclear de um direito fundamental. Mesmo porque os direitos fundamentais previstos na Constituição têm caráter distintos, sejam individuais, sociais, difusos. Consequentemente, têm aspectos vitais diferenciados, podendo até mesmo, dentro de sua essencialidade, exigir uma posição ativa para sua eficácia, sob pena de não serem devidamente garantidos, como é o caso dos direitos sociais.

Para o mero fim de uma sistematização, pode-se considerar como núcleo essencial de um direito fundamental o mínimo necessário à consecução daquilo que se quer ver protegido, do objeto que define o direito humano fundamental, seja por meio de ações negativas ou ações positivas. Logo, qualquer tentativa de relativização de direitos considerados fundamentais, portanto, deverá respeitar o limite material do núcleo essencial de cada direito, ou seja, o mínimo existente para manter inalterada a integridade do bem que sustenta a acepção de fundamentalidade dos direitos e que está sendo por eles previsto e protegido: a dignidade humana.

O reconhecimento da aplicação do princípio da proibição do retrocesso social significa impedir que a efetividade da Constituição seja frustrada, limitando que a atuação do legislador infraconstitucional seja realizada em contrariedade à vontade do Poder Constituinte originário. Assim, o texto constitucional, além de estabelecer tarefas ao Estado no sentido de criar instituições ou serviços para realizar um direito fundamental de cunho social, obriga também a sua não abolição uma vez criados.

O princípio da vedação do retrocesso social, decorrente da noção de Constituição Dirigente, estabelecida pelo constitucionalista português J. J. Gomes Canotilho, a partir de um conteúdo pragmático-constitucional no qual é atribuída ao Estado a realização de fins e consecução de tarefas, proclama que uma vez realizado o direito fundamental social a partir da regulamentação infraconstitucional, ou seja, uma vez integrado seu conteúdo no ordenamento jurídico a fim de garantir sua eficácia e aplicabilidade, torna-se incabível qualquer reversão dessa medida sem que seja realizada uma nova regulamentação substitutiva ou equivalente. 
Entretanto, diante da sistemática do Estado Democrático de Direito, motivador do princípio da confiança e da segurança jurídica, e da garantia da observância dos mínimos sociais alcançados dentro de uma máxima eficiência e efetividade das normas de direitos fundamentais sociais, é possível conferir a possibilidade de aplicação de uma reversibilidade relativa ao princípio da proibição do retrocesso social, adstrita, por óbvio, à total e irrestrita proteção ao núcleo essencial, este, sim, conforme já apontado, de caráter absoluto.

O principal alcance (e, consequentemente, objetivo) para a aplicação de uma proteção contra o retrocesso social é garantia do núcleo essencial, cujo conceito já foi visitado neste trabalho. Mesmo diante da admissão de um caráter relativo à sua observância, a proibição do retrocesso social vai até o limite da proteção ao núcleo essencial e ao nível de conformação por ele já assegurado. Assim, é o núcleo essencial e sua concretização a primeira barreira de vinculação do legislador para não realização de retrocesso social, uma vez que tal noção está intimamente conectada ao princípio da dignidade da pessoa humana.

Superada a questão da necessária manutenção do núcleo essencial e do grau mínimo de conformação conseguido, outra forma de amplitude deve estar indispensavelmente vinculada à noção de proteção contra o retrocesso social. Dentro dessa perspectiva, toda e qualquer medida restritiva de direitos sociais deve ser encarada com reservas e sob uma presunção, ainda que relativa, de inconstitucionalidade, estando sujeita a um exame de justificativa e proporcionalidade, sempre à luz da dignidade da pessoa humana.

O direito fundamental à previdência social foi estabelecido pela Constituição de 1988 como uma das formas de proteção social, com vistas à dignidade da pessoa humana. Uma concepção de previdência social deve partir, necessariamente, da ideia de bem estar social, sendo seu objetivo principal a preservação da dignidade da pessoa humana e, consequentemente, a proteção dos direitos humanos. Dentro dessa perspectiva, o direito do indivíduo à proteção social prevista por um sistema de previdência social constitui-se em um valor. E, para haver a respectiva observância e consequente exigência, esse valor deve ser garantido como um direito fundamental.

Com base nessa análise, o direito à previdência social apresenta um núcleo essencial inafastável e intocável, o qual não pode ser objeto de restrição ou extinção, sob pena de se configurar retrocesso social. E o núcleo essencial do direito à previdência social pode ser 
verificado por meio dos próprios eventos listados pela Constituição brasileira nos incisos de seu artigo 201 (morte, doença, invalidez, velhice, maternidade, desemprego, reclusão e formação de família), assim considerados pelo legislador constitucional originário como relevantes circunstâncias que podem afetar negativamente o desenvolvimento do homem de tal modo a ponto de atingir sua dignidade.

A eliminação dessas contingências ou a ausência de prestações previdenciárias que garantam a plena eficácia e eficiência da proteção contra tais situações atinge frontalmente o núcleo essencial do direito à previdência social, tornando-se cristalinos e indiscutíveis retrocessos sociais e eivando a medida de caráter inconstitucional.

Para o devido atendimento, a Previdência Social deve ser organizada de forma a atingir, com a maior eficácia e disponibilidade possíveis, os seus propósitos. Assim, a estrutura previdenciária brasileira vem sendo construída de forma a permitir que a proteção social seja amplamente externalizada de forma eficiente, produtiva e justa. Cada conquista social no âmbito previdenciário deve ser assumida e garantida, sob pena de se configurar retrocesso social.

Dentro de uma estrutura previdenciária, a ofensa ao princípio da proibição do retrocesso social pode ocorrer tanto no âmbito do custeio quanto no âmbito do fornecimento de prestações. No primeiro caso, é imprescindível ter em mente, à luz do princípio da proibição do retrocesso social, a impossibilidade de qualquer modificação que promova a redução dos direitos sociais anteriormente garantidos, a limitação do acesso aos mesmos ou a modificação daqueles sem uma correspondente substituição igualmente protetiva e eficaz. Deste modo, a percepção de novos modelos de financiamento do sistema de previdência social deve buscar soluções viáveis a partir do mercado de trabalho e de novas políticas econômicas e sociais, sem que o que nível de proteção já garantido sofra qualquer revés.

Deste modo, à luz da necessidade de proteção aos direitos fundamentais e, principalmente, de garantia da dignidade humana, faz-se necessária a busca por alternativas válidas e eficazes que impossibilitem a redução dos direitos sociais já consagrados e garantidos sem limitar a competitividade frente a uma estrutura globalizada. 
No que tange às prestações concedidas pela Previdência Social, as mesmas têm como escopo garantir a sobrevivência do indivíduo que faz parte do sistema (segurado) durante o período em que atingido por uma contingência social que o impossibilita de prover o próprio sustento e de sua família. Ou seja, são prestações concedidas com o objetivo de garantir a dignidade humana mesmo em situações adversas, evitando-se a exclusão social.

Por esta razão é que as prestações de cunho previdenciário devem ser analisadas à luz do direito fundamental social à Previdência Social, haja vista que garantem a sua observância e aplicabilidade. Dentro dessa perspectiva, qualquer alteração na estrutura das prestações concedidas deve estar submetida ao princípio da proibição do retrocesso social. Deve o Estado, a exemplo dos demais direitos fundamentais, se posicionar no sentido de impedir a eliminação ou a limitação ao direito de ter proteção previdenciária. Por outro lado, mais além, deve garantir sua observância e aplicabilidade a partir da criação de políticas que viabilizem o acesso ao direito fundamental à Previdência Social.

Por outro lado, além de ser considerada direito fundamental, a Previdência Social, também deve ser constitucionalmente preservada sob a faceta de instituição criada para a estruturação do direito fundamental de origem, sendo um dever do Estado garantir sua completa e transparente eficácia.

A questão da garantia institucional é uma criação da doutrina alemã e compreendia as garantias jurídico-públicas e jurídico-privadas. Nada obstante ter embasamento e proteção constitucional, não se confunde com direito fundamental, na medida em que não se traduz em direitos atribuídos diretamente a uma pessoa, mas apenas reflete a proteção dos direitos fundamentais, individuais e sociais. Assim. a instituição pode ser definida como o fenômeno jurídico no qual são apresentados esquemas regulativos para existência e funcionamento de normas constitucionais.

Consequentemente, por se tratar de uma garantia institucional, a Previdência Social (e a Seguridade Social como um todo), em sua estruturação, também conta com a proteção constitucional, sendo-lhe assegurada a segurança e a sobrevivência de sua condição de instituição e configurando um dever do Estado na medida em que resvala em interesse legítimo da sociedade que o sustenta. 
Em uma acepção prática da aplicação do princípio da proibição do retrocesso social, como consequência das considerações expostas neste estudo, o princípio da proibição do retrocesso social não pode ser entendido de forma absoluta. Daí se tratar de princípio e não de regra, na qual a margem de proteção fica imbuída de caráter imutável.

Até mesmo porque, uma noção de proibição absoluta ao retrocesso social acaba por ir de encontro à possibilidade do legislador de escolher a melhor opção dentre as existentes, de forma discricionária. Impede, ainda, o legislador de promover os ajustes necessários ao atingimento da maior eficácia possível ao direito fundamental social, dentro do limite do que já foi conquistado.

Nessa medida, há de se considerar a possibilidade de se permitir uma reversibilidade relativa dos direitos fundamentais. E essa reversibilidade somente pode ser relativamente entendida porque, para produzir efeitos, necessariamente precisa atender a dois requisitos essenciais: o primeiro é o não atingimento do núcleo essencial e do nível de conformação já alcançado e o segundo é o exame da justificativa e proporcionalidade da medida de reversibilidade, já que detém uma presunção de inconstitucionalidade pela própria natureza do direito em debate.

Isso porque toda medida que atinge o núcleo essencial é retrocessiva e fulminada pelo princípio da proibição do retrocesso social, mas nem toda medida que apresente caráter de reversibilidade é retrocessiva, uma vez que sujeita à avaliação de atingimento do núcleo essencial e ao juízo de ponderação da justificativa e proporcionalidade da modificação proposta. Não é toda reversibilidade que é proibida porque não é toda alteração que afeta o núcleo essencial ou é arbitrária, discriminatória, ou ofensiva. Nesse contexto, apesar do caráter retrocessivo, o princípio da proibição do retrocesso social cede espaço para outros interesses sociais considerados mais relevantes.

Para a realização do controle de constitucionalidade de uma medida retrocessiva, dois grupos de avaliações revelam-se imprescindíveis: o primeiro, relacionado à verificação da observância do núcleo essencial do direito fundamental; o segundo, relacionado à apuração da adequação e proporcionalidade da medida, a partir dos critérios de idoneidade, necessidade e justiça, considerados à luz do princípio da proibição deficiente, e de igualdade, segurança jurídica e proteção da confiança e racionalidade na fundamentação. Supridos todos esses 
requisitos, a medida, mesmo tendo caráter retrocessivo, pode ser declarada em consonância com a Constituição e, portanto, constitucional.

Por outro lado, a realização do controle de constitucionalidade de uma medida retrocessiva também está sujeita à modulação de seus efeitos temporais, isto é, da determinação judicial do momento em que medida se torna inconstitucional, tendo, em contrapartida, gerado efeitos regulares desde sua criação até sua declaração de inconstitucionalidade.

No entanto, no caso específico das medidas de cunho social com caráter retrocessivo para ser consideradas inconstitucionais devem, necessariamente, deixar de observar o núcleo essencial do direito fundamental ou de cumprir um dos requisitos de ponderação da justificativa e da proporcionalidade da alteração proposta.

Se uma medida de caráter retrocessivo viola o núcleo essencial de um direito fundamental social, ela deve ser imediatamente declarada inconstitucional, sem sequer ser considerada a possibilidade de modulação de seus efeitos. Isso porque, quando uma medida atinge o núcleo essencial de um direito, e, portanto, da própria dignidade humana, não pode haver razão que justifique o interesse social na constitucionalidade da medida. Não há interesse social que ratifique a ofensa ao princípio basilar da dignidade da pessoa humana.

A modulação dos efeitos temporais pelo argumento da segurança jurídica, por outro lado, também não se justifica nesse caso, uma vez que a própria segurança jurídica é um dos fundamentos da proteção constitucional aos direitos fundamentais. Ainda, não pode haver confiança em um ordenamento jurídico que sustenta medidas retrocessivas que atingem o mínimo básico existencial, em detrimento do bem maior dos direitos humanos e dignidade.

Vislumbra-se, pois, que, a aplicação da modulação dos efeitos temporais do controle de constitucionalidade não deve ser estendida a medidas retrocessivas de cunho social, uma vez que sob todos os ângulos analisados, não se identifica possibilidade de justificativa para tal procedimento, uma vez que os requisitos que poderiam embasar a sua utilização (interesse social e segurança jurídica) já foram superados e afastados pelo próprio reconhecimento da inconstitucionalidade. 
Tal afirmativa pode, inclusive, ser corroborada pela própria análise dos casos práticos trazidos pelo presente estudo. As medidas consideradas retrocessivas que impuseram a aplicação do fator previdenciário, excluíram o garimpeiro do rol de segurados especiais do sistema de previdência social, limitaram a responsabilidade estatal sobre o acidente do trabalho e o grau de extensão do benefício do auxílio reclusão foram, a partir da análise dos critérios necessários a sua constitucionalidade, consideradas injustificadas à luz da proibição do retrocesso social por não refletirem a adequação e a proporcionalidade necessárias a sua aceitação no ordenamento jurídico. Diante de uma inconstitucionalidade flagrante, o interesse social ou a segurança jurídica das relações sociais não se revelam aptos a suportar qualquer tipo de modulação de efeitos.

Observa-se, desde modo, que o sistema previdenciário brasileiro está sempre sujeito a uma infinidade de modificações legislativas na busca pela garantia de um sistema equilibrado financeira e atuarialmente. Várias dessas modificações são realizadas sem qualquer estudo prévio da adequação e da proporcionalidade das medidas a serem implementadas, principalmente com vistas à proteção constitucional ao direito fundamental à previdência social, razão pela qual acabam por ser fulminadas pela inconstitucionalidade.

Para a garantia de um sistema voltado à proteção da dignidade humana e à justiça social, revela-se imprescindível a realização de uma análise detalhada do impacto de eventual medida de caráter retrocessivo, de forma a apurar se suas disposições não afrontam, em primeiro lugar, o núcleo essencial do direito fundamental e, em segundo lugar, as ponderações de proibição de proteção deficiente, igualdade, segurança jurídica e racionalidade, sob pena ser declarada inconstitucional pela inobservância do princípio da proibição do retrocesso social. 


\section{REFERÊNCIAS}

ALEXY, Robert. Teoria dos Direitos Fundamentais. Trad. Virgílio Afonso da Silva. São Paulo: Malheiros, 2008

ARENDT, Hannah. As Origens do Totalitarismo. II Imperialismo, a expansão do poder. Rio de Janeiro: Editora Documentário, 1976

BARros, Suzana de Toledo. O Princípio da Proporcionalidade e o Controle de Constitucionalidade das Leis Restritivas de Direitos Fundamentais. Brasília, DF: Livraria e Editora Brasília Jurídica, 1996.

BARROSO, Luis Roberto. Os Princípios da Razoabilidade e da Proporcionalidade no Direito Constitucional. Cadernos de Direito Constitucional e Ciência Política. São Paulo: Instituto Brasileiro de Direito Constitucional, ano 6, n. 23, abril-junho de 1998.

. O Direito Constitucional e a Efetividade de suas Normas. 9. ed. Rio de Janeiro: Renovar, 2009.

BOBBIO, Giorgio. DI GIOVANNI, Donatella Morello. MORINO, Marilena. Diritto dei Servizi Sociali. Roma: Carocci Faber, 2006.

BOBBIO, Norberto. Estado, Governo e Sociedade. 4. ed. Rio de Janeiro: Paz e Terra, 1995.

A Era dos Direitos. nova ed. 5. reimpressão. Rio de Janeiro: Elsevier, 2004.

CANOTILHO, José Joaquim Gomes. Direito Constitucional e Teoria da Constituição. 7. ed. 8. reimpressão. Coimbra: Almedina, 2003.

Constituição Dirigente e Vinculação do Legislador. 2. ed. Coimbra: Coimbra Editora, 2001.

. Estudos sobre Direitos Fundamentais. Coimbra: Coimbra Editora, 2004. 
CANOTILHO, José Joaquim (Org.) et alii. Direitos Fundamentais Sociais. São Paulo: Saraiva, 2010.

CASTRO, Carlos Alberto Pereira de, LAZZARI, João Batista. Manual de Direito Previdenciário. 5. ed. São Paulo: LTr, 2004.

COMPARATO, Fábio Konder. Afirmação Histórica dos Direitos Humanos. 7. ed. rev. e atual. São Paulo: Saraiva, 2010.

Ética: direito, moral e religião no mundo moderno. 2. ed. rev. São Paulo: Companhia das Letras, 2006. p. 87.

CONTO, Mário de. O Princípio da Proibição do Retrocesso Social: uma análise a partir dos pressupostos da hermenêutica filosófica. Porto Alegre: Livraria do Advogado Editora, 2008.

CORREIA, Marcus Orione Gonçalves. Direitos Humanos e Direitos Sociais: interpretação evolutiva e segurança social. Revista do Departamento de Direito do Trabalho e da Seguridade Social. São Paulo: Faculdade de Direito da USP, n. 1, p. 117-135. janeiro-junho, 2006.

CORREIA, Marcus Orione Gonçalves, CORREIA, Érica Paula Barcha. (coordenação) Direito Previdenciário e Constituição. São Paulo: LTr, 2004.

. Curso de Direito da Seguridade Social. 3. ed. revista, ampliada e atualizada. São Paulo: Saraiva, 2007.

CORREIA, Marcus Orione Gonçalves, VILLELA, José Correia. (coordenação) Previdência Privada. Doutrina e Comentários à Lei Complementar no 109/01. São Paulo: LTr, 2005.

COSTA, Eliane Romeiro. Desenvolvimento Social - política pública para a inclusão previdenciária do trabalhador de baixa renda. Revista da Previdência Social. São Paulo: LTr, n. 309, p. 528-530. agosto 2006. 
COUTINHO, Jacinto Nelson de Miranda (organização). Canotilho e a Constituição Dirigente. 2. ed. Rio de Janeiro: Renovar, 2005.

CYTRYNOWICZ, Roney. Memória da Barbárie: a história do genocídio dos judeu na segunda guerra mundial. 2. ed. São Paulo: Nova Stella: Editora da Universidade de São Paulo, 1991.

DEL GIUDICE, F. et alii. Compendio di Diritto dela Previdenza Sociale. I volume di base. V edizioni. Napoli: Gruppo Editoriale Esselibri - Simone, 2007.

DERBLI, Felipe. O Princípio da Proibição do Retrocesso Social na Constituição de 1988. Rio de Janeiro: Renovar, 2007.

DUPEYROUX, Jean-Jacques. etalii. Droit de la sécurité sociale. $15^{\mathrm{e}}$ édition. Paris: Éditions Dalloz, 2005.

DWORKIN, Ronald. Levando os direitos a sério. Trad. Nelson Boeira. 2. ed. São Paulo: Martins Fontes, 2007.

FAVOREU, Louis et. alii. Tribunales Constitucionales Europeos y Derechos Fundamentales. Madrid: Centro de Estudios Constitucionales, 1984.

FELICIANO, Guilherme Guimarães. Direito e Economia: Marx, Althussen e os desafios da sociedade capitalista na era pós-industrial. Revista da Faculdade de Direito de Taubaté. Taubaté: Universidade de Taubaté, n. 6, p. 42-70. janeiro-dezembro 2004.

Direito à Prova e Dignidade Humana: cooperação e proporcionalidade em provas condicionadas à disposição física da pessoa humana (abordagem comparativa). São Paulo: LTr, 2007.

- Guilherme Guimarães. Tutela Processual de Direitos Humanos Fundamentais: inflexões no "due processo of law". Tese. Lisboa: Faculdade de Direito da Universidade de Lisboa, 2012 (prelo). 
FERRAZ JUNIOR, Tércio Sampaio. Estudos da Filosofia do Direito. Reflexões sobre o Poder, a Liberdade, a Justiça e o Direito. 2. ed. São Paulo: Altas, 2003.

FERREIRA, Lauro César Mazetto. Seguridade Social e Direitos Humanos. São Paulo: LTr, 2007.

FERREIRA FILHO, Manoel Gonçalves. Princípios Fundamentais de Direito Constitucional. 2. ed. São Paulo: Saraiva, 2010.

FIGUEIREDO, Guilherme José Purvin de. Direito Ambiental e a Saúde dos Trabalhadores. 2. ed. São Paulo: LTr, 2007.

FILETI, Narbal Antônio Mendonça. A Fundamentalidade dos Direitos Sociais e o Princípio da Proibição de Retrocesso Social. Florianópolis: Conceito Editorial, 2009.

FRISCHEINSEN, Luiza Cristina Fonseca. Proteção e garantia dos direitos humanos: alguns aspectos da atuação do MP. Revista da Faculdade de Direito de Taubaté. Taubaté: Universidade de Taubaté, n. 6, p. 132-146. janeiro-dezembro 2004.

GARCIA, Emerson. (coordenação) A Efetividade dos Direitos Sociais. Rio de Janeiro: Lumen Juris, 2004.

GEBRAN NETO, João Pedro. A Aplicação Imediata dos Direitos e Garantias Individuais: a busca de uma exegese emancipatória. São Paulo: Editora Revista dos Tribunais, 2002.

GIAMBIAGI, Fabio. Reforma da Previdência: o encontro marcado. 2. ed. Rio de Janeiro: Elsevier, 2007.

GOMES, Eduardo Biacchi. et alii. Direito Previdenciário em Debate. Curitiba: Juruá, 2007.

GRAU, Eros Roberto. Ensaio e discurso sobre a interpretação/aplicação do direito. $4^{\mathrm{a}}$ ed. São Paulo: Malheiros, 2006. 
GUERRA FILHO, Willis Santiago. Ensaios de Teoria Constitucional. Ceará: Imprensa Universitária da Universidade Federal do Ceará, 1989.

HÄBERLE, Peter. Hermenêutica Constitucional: a sociedade aberta dos intérpretes da Constituição: a contribuição para a interpretação pluralista e "procedimental" da Constituição. Trad. Gilmar Ferreira Mendes. Porto Alegre: Sergio Antonio Fabris Editor, 1997.

La Garantía del Contenido Esencial de los Derechos Fundamentales en la Ley Fundamental de Bonn: una contribución a la concepción institucional de los derechos fundamentales y a la teoría de la reserva de la ley. Traducción: Joaquin Brage Camazano. Madrid: Dykinson, 2003.

HERNÁNDEZ, Juan Gorelli. et alii. Sistema de Seguridad Social. duodécima edición. Madrid: Editorial Tecnos, 2010.

HESS, Konrad. A Força Normativa da Constituição. Porto Alegre: Sérgio Fabris Editor, 1991.

HORVATH JUNIOR, Miguel. Previdência Social em face da Globalização. São Paulo: Quartier Latin, 2006.

HOUAISS, Antonio e VILLAR, Mauro de Salles. Minidicionário Houaiss da língua portuguesa. 3. ed. revista e aumentada. Rio de Janeiro: Objetiva, 2009.

HUNT, Lynn. A Invenção dos Direitos Humanos: uma história. Trad. Rosaura Eichenberg. São Paulo: Companhia das Letras, 2009.

JORGE, Tarsis Nametala Sarlo. O Custeio da Seguridade Social. 2. ed. Rio de Janeiro: Lumen Juris, 2007.

KANT, Immanuel. Fundamentação da Metafísica dos Costumes e outros escritos. Trad. Leopoldo Holzbach. São Paulo: Martin Claret, 2004. 
LEITE, George Salomão. (organização) Dos Princípios Constitucionais. Considerações em Torno das Normas Principiológicas da Constituição. São Paulo: Malheiros, 2003.

LOVELAND, Ian. Constitutional Law, Administrative Law, and Human Rights. 5th. Oxford: Oxford University Press, 2009.

MANSUELI, Hugo Roberto. Derechos Sociales en El Mercosur. Direito Previdenciário em Debate. Coord. Instituto Brasileiro de Direito Previdenciário. Curitiba: Juruá, 2007.

MARTINEZ, Wladimir Novaes. Subsídios para um modelo de previdência social para o Brasil: 1216 reflexões para os estudiosos. São Paulo: LTr, 2008.

MARTINS, Sérgio Pinto. Direito da Seguridade Social. 27. ed. São Paulo: Atlas, 2009. Fundamentos de Direito da Seguridade Social. 7. ed. São Paulo: Altas, 2006.

MAZZILLI, Hugo Nigro. A Defesa dos Interesses Difusos em Juízo. 15. ed. revista atualizada e ampliada. São Paulo: Saraiva, 2002.

NASCIMENTO, Sérgio. Interpretação do Direito Previdenciário. São Paulo: Quartier Latin, 2007.

NETTO, Luísa Cristina Pinto e. O Princípio da Proteção do Retrocesso Social. Porto Alegre: Livraria do Advogado, 2010.

NOWAK, John. ROTUNDA, Ronald D. Principles of Constitutional Law. 4th Ed. Minnesotta: Thomson Reuters, 2010.

OLIVEIRA, Fábio de. A Constituição Dirigente: Morte e Vida no Pensamento do Doutor Gomes Canotilho. Revista Brasileira de Direito Comparado. Rio de Janeiro: Instituto de Direito Comparado Luso-Brasileiro, 2005, n. 28. 
OLIVERA, Julio Ramos. Manual Práctico de Aportes a La Seguridad Social. Montevideo: B de F Ltda., 2000.

OLIVEIRA, Paulo Rogério Albuquerque. Saúde dos trabalhadores perante dos direitos fundamentais: uma crítica propositiva. Revista da Previdência Social. São Paulo: LTr, n. 312, p. 781-793, novembro 2006.

PIERSON, Paul. The New Politics of the Welfare State. Oxford: Oxford University Press, 2001 .

PIOVESAN, Flávia. Direitos Humanos e o Direito Constitucional Internacional. 3. ed. atual. São Paulo: Max Limonad, 1997.

QUEIROZ, Cristina M. M. Direitos Fundamentais (teoria geral). Coimbra: Coimbra Editora, 2002.

. O Princípio da Não Reversibilidade dos Direitos Fundamentais Sociais: princípios dogmáticos e prática jurisprudencial. Coimbra: Coimbra Editora, 2006.

ROCHA, Daniel Machado da. O Direito Fundamental à Previdência Social. Na perspectiva dos princípios constitucionais diretivos do sistema previdenciário brasileiro. Porto Alegre: Livraria do Advogado, 2004.

ROCHA, Daniel Machado da, SAVARIS, José Antonio. (coordenação) Curso de Especialização em Direito Previdenciário. Curitiba: Juruá, 2006. v. 1 e 2.

SARLET, Ingo Wolfgang. Dignidade da Pessoa Humana e Direitos Fundamentais na Constituição de 1988. Porto Alegre: Livraria do Advogado, 2001.

. O Estado Social de Direito, a Proibição de Retrocesso e a Garantia Fundamental da Propriedade. Revista Eletrônica sobre a Reforma do Estado (RERE). n ${ }^{\circ}$. Salvador: Instituto Brasileiro de Direito Público, março/abril/maio, 2007. Disponível em $<$ http://www.direitodoestado.com.br/rere.asp.> Acesso em: 20 de março de 2011. 
A Eficácia dos Direitos Fundamentais: uma teoria geral dos direitos fundamentais na perspectiva constitucional. 10. ed. revista, atualizada e ampliada. Porto Alegre: Livraria do Advogado, 2009.

SERAU JUNIOR, Marco Aurélio. Seguridade Social como Direito Fundamental Material. Curitiba: Juruá, 2009.

SILVA, José Afonso da. Curso de Direito Constitucional Positivo. 14. ed. revista e atualizada nos termos da Reforma Constitucional. São Paulo: Malheiros, 1997.

Aplicabilidade das Normas Constitucionais. 6. ed. São Paulo: Malheiros, 2002.

SILVA, Sidney Jard da. Novos Modelos Previdenciários na América Latina: lições da experiência argentina. Revista de Economia Política. São Paulo: Centro de Economia Política, vol. 28, n. 2, junho 2008.

SILVA, Virgílio Afonso. O proporcional e o razoável. Revista dos Tribunais 798. São Paulo: Editora Revista dos Tribunais, 2002, ano 91.

. Direitos Fundamentais: conteúdo essencial, restrições e eficácia. 2. ed. São Paulo: Malheiros, 2010.

SIMM, Zeno. Os Direitos Fundamentais e a Seguridade Social. São Paulo: LTr, 2005.

SteINMETZ, Wilson. Princípio da Proporcionalidade e Atos de Autonomia Privada. Interpretação Constitucional. Org. Virgílio Afonso da Silva. 1. ed. 2. tiragem. São Paulo: Editora Malheiros, 2007.

STRECK, Lenio Luiz. Jurisdição Constitucional e Hermenêutica. 2. ed. revista e ampliada Rio de Janeiro: Forense, 2004.

TRINDADE, José Damião de Lima. História Social dos Direitos Humanos. São Paulo: Peirópolis, 2002. 
TSUTIYA, Augusto Massayuki. Curso de Direito da Seguridade Social. São Paulo: Saraiva, 2007.

VIDAL NETO, Pedro. Natureza Jurídica da Seguridade Social. Tese (Titular). Faculdade de Direito da Universidade de São Paulo. São Paulo, 1993.

ZENI, Nelson Larrañaga. Manual de benefícios laborales y de la seguridad social. Montevideo: Editorial Amalio M. Fernandez S. R. L., 2006. 